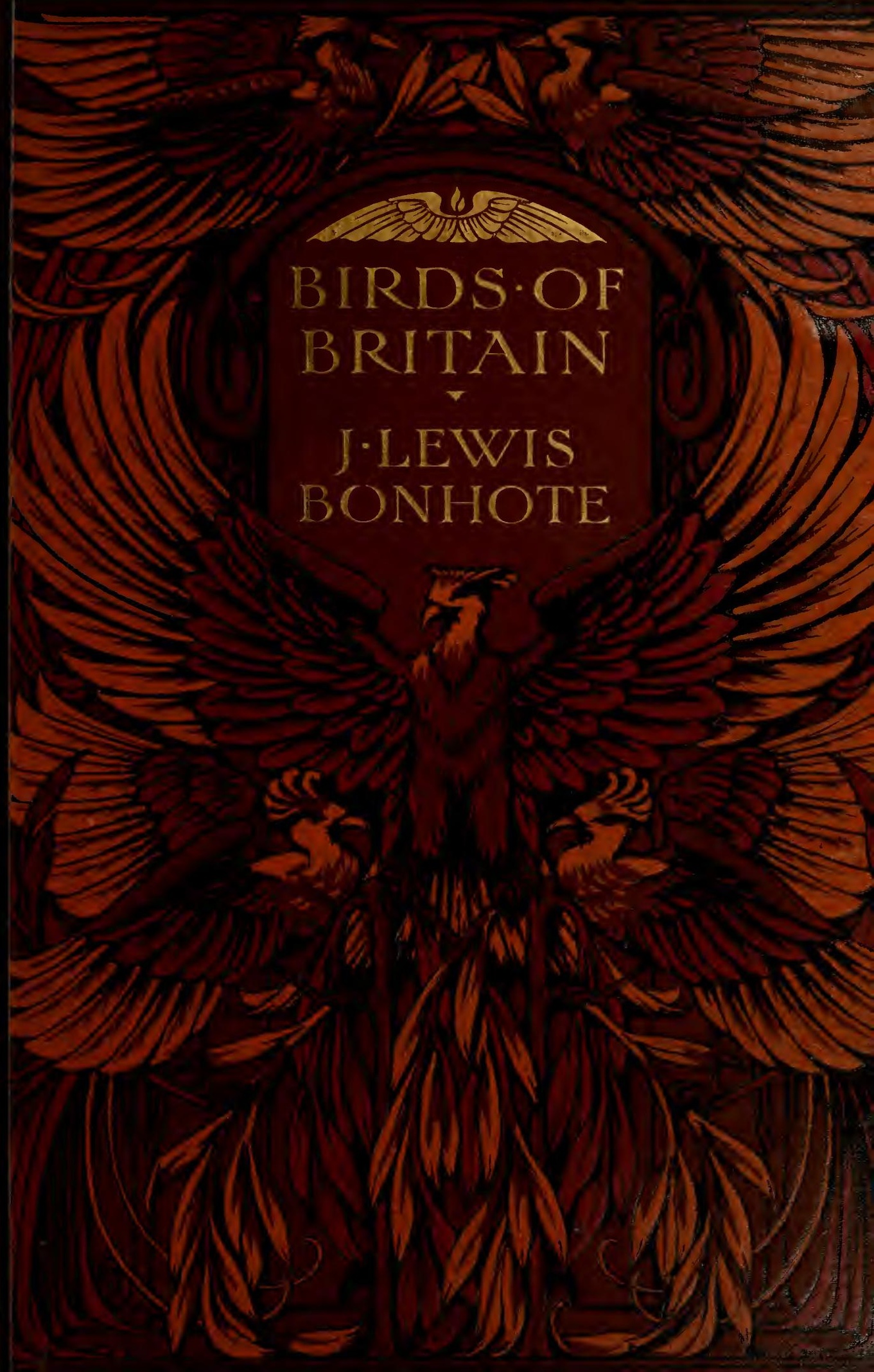




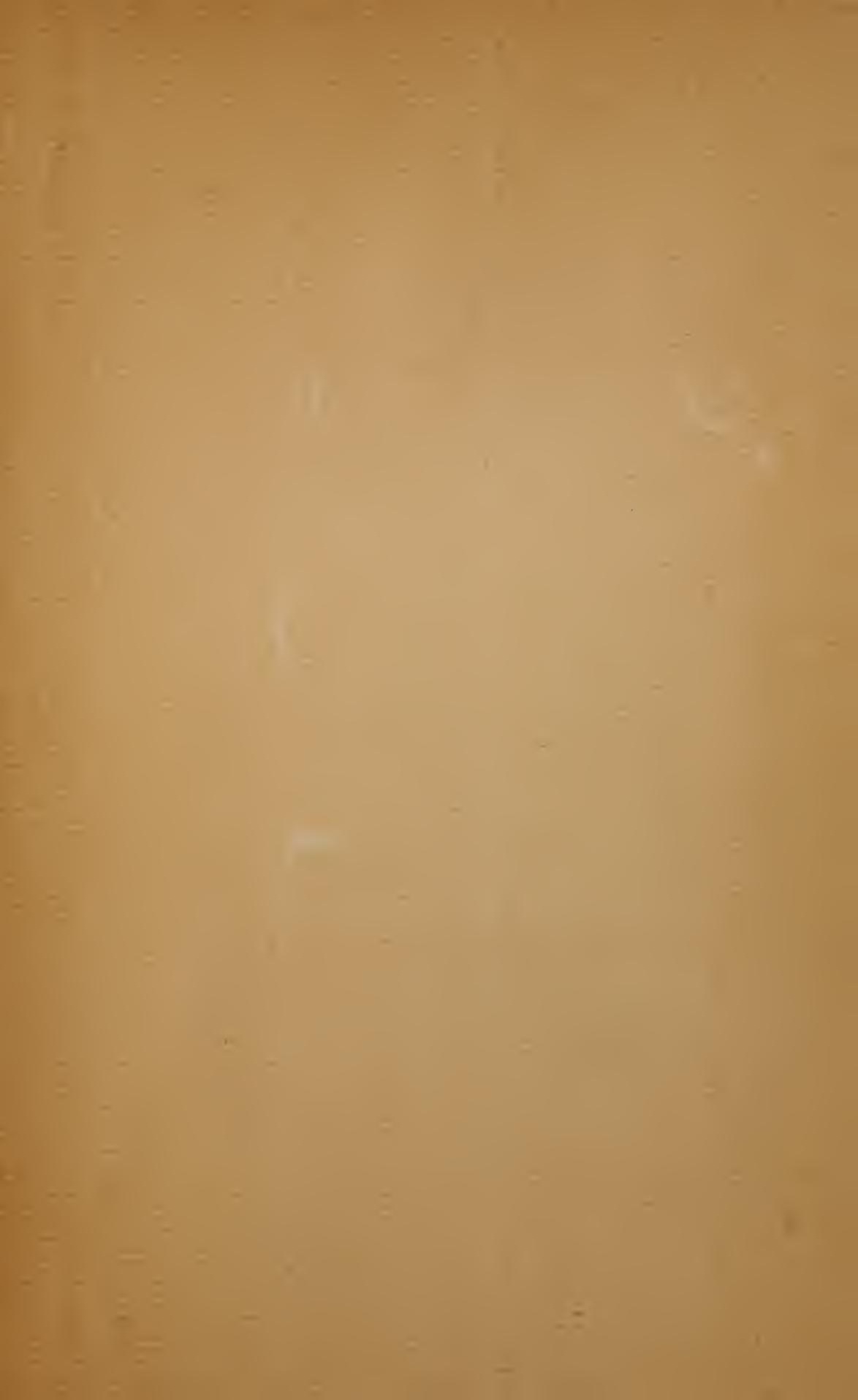



BIRDS OF BRITAIN 


\section{AGENTS}

America the Macmillan Compans 64 \& 66 Fifth Avenue, New York

Canada The Macmillan Company of Canada, Lto. 27 Richmond Street West, Toronto

INdia . Macmillan \& Company, Ltd. Macmillan Building, Bombay 309 Bow Bazaar Street, Calcutta 



\title{
BIRDS OF BRITAIN
}

BY

\author{
J. LEWIS BONHOTE \\ M.A., F.L.S., F.Z.S. \\ MEMBER OF THE BRITISH ORNITHOLOGISTS' UNION
}

WITH

100 ILLUSTRATIONS IN COLOUR

SELECTED BY

H. E. DRESSER

FROM HIS 'BIRDS OF EUROPE'

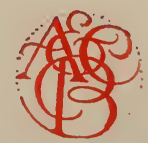

LONDON

ADAM AND CHARLES BLACK

1907 
Published November 1907

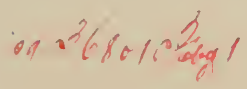




\section{PREFACE}

THE study of Nature has of late years enormously increased, and there is probably no branch of its varied and inexhaustible interests which appeals more strongly to young and old than the fascinating study of Birds.

Every one feels more or less interested in Birds, whether it be from pure affection for the Robins and Tits which beg our hospitality during the winter months, or joy at the coming of the Swallow and Cuckoo as heralds of spring.

For some the interest is perhaps merely a passing regret at the shooting of one of our rare and beautiful migrants, while with others the real love of bird life makes it a moment of intensest pleasure when, for instance, the melodious note of the Nightingale makes us dimly realise something of the innate beauty of Nature herself.

In the following pages will be found not only descriptions and plates of the birds themselves, but, wherever possible, notes on their ways and habits have also been given. These notes having been taken at first hand straight from Nature, it is hoped that they may give a small insight 


\section{Birds of Britain}

into some of those beautiful mysteries which it is our ambition to unravel, and that, at the same time, they may awaken and stimulate a further desire to know still more of the workings of the great laws of the Universe and the part they play in the lives of even the least of the feathered creatures.

It has been thought best to include in this book every species which has been known to occur in Great Britain, with a description of their leading characteristics and true habitat, so that any bird met with may be easily identified; and the plates have been carefully selected so as to give examples of the most typical species.

For facts relative to geographical distribution and other technical details the author has freely consulted Mr. Howard Saunders' Manual of British Birds.

In conclusion, the author hopes most sincerely that this book may, often prove to be of help and service to the genuine seeker after reliable information on British Birds, and also that it may encourage observation and further research in a branch of Natural History where discovery ever stimulates to fresh discovery and where interest never fails.

J. LEWIS BONHOTE.

Gade Spring,

Hejer Hempstead, Herts,

November 1907. 


\section{LIST OF ILLUSTRATIONS}

1. Missel Thrush Frontispiece
FACING PAGE

2. Song Thrush . . . . . . . . . 4

3. Fieldfare . . . . . . . . 10

4. Blackbird . . . . . . . . 16

5. Ring Ouzel . . . . . . . . 20

6. Wheatear . . . . . . . . . 22

7. Stonechat . . . . . . . 30

8. Redstart . . . . . . . . . 32

9. Robin . . . . . . . . 36

10. Nightingale . . . . . . 38

11. Whitethroat . . . . . . . . 40

12. Lesser Whitethroat . . . . . . . 42

13. Blackcap . . . . . . . . . 46

14. Dartford Warbler . . . . . . . 48

15. Fire-crested Wren and Golden-crested Wren . . 50

16. Chiffchaff and Willow Wren . . . . . 54

17. Reed Warbler and Marsh Warbler . . . . 60

18. Grasshopper Warbler . . . . . . 66

19. Hedge Accentor (Hedge Sparrow) . . . 68

20. Bearded Reedling . . . . . . . 72

21. Long-tailed Tit . . . . . . . 74

22. Great Tit . $\quad . \quad$. $\quad . \quad$. $\quad$. 76

23. Narsh Tit . . . . . . . 78 


\section{Birds of Britain}

24. Nuthatch

25. Common Wren

26. Tree-Creeper

27. Pied Wagtail

28. Grey Wagtail .

29. Blue-headed Wagtail

30. Tree Pipit and Meadow Pipit

31. Red-backed Shrike

32. Waxwing

33. Spotted Flycatcher

34. Sand-Martin

35. Greenfinch

36. Goldfinch

37. Tree-Sparrow

38. Chaffinch

39. Linnet

40. Mealy Redpoll .

41. Bullfinch

42. Crossbill .

43. Yellow Bunting (Yellow Hammer)

44. Cirl Bunting

45. Snow Bunting and Lapland Bunting

46. Starling .

48. Magpie

49. Jackdaw .

50. Rook

51. Skylark .

52. Common Swift .

53. Wryneck 


\section{List of Illustrations}

56. Cuckoo

57. Barn Owl

58. Long-eared Owl

59. Tawny Owl

60. Golden Eagle .

61. Peregrine

204

62. Kestrel

212

63. Shag

216

220

64. Bittern

228

65. Sheld-Duck

240

66. Mallard or Wild Duck

242

67. Shoveller

246

68. Wigeon

252

69. Tufted Duck

256

70. Common Scoter

262

71. Red-breasted Merganser

266

72. Stock Dove

270

73. Turtle Dove .

272

74. Red Grouse

276

75. Partridge.

280

76. Land-Rail

284

77. Water-Rail

286

78. Moor-hen .

288

79. Stone Curlew

294

80. Ringed Plover

300

81. Golden Plover and Grey Plover

304

82. Lapwing .

308

83. Oyster-Catcher .

84. Grey Phalarope and Red-necked Phalarope . . . 314

85. Woodcock

86. Dunlin

87. Redshank 


\section{Birds of Britain}

88. Curlew . . . . . . 348

89. Common Tern . . . . . . 354

90. Black-headed Gull . . . . . . 360

91. Herring Gull . . . . . . 364

92. Greater Black-backed Gull . . . . 368

93. Kittiwake . . . . . 370

94. Richardson's Skua . . . . . . . 374

95. Razorbill. . . . . . 376

96. Common Guillemot . . . . . . 378

97. Black Guillemot . . . . 380

98. Red-throated Diver . . . . 386

99. Great-crested Grebe . . . . . . . 388

100. Storm Petrel and Leach's Petrel . . . . . 392 



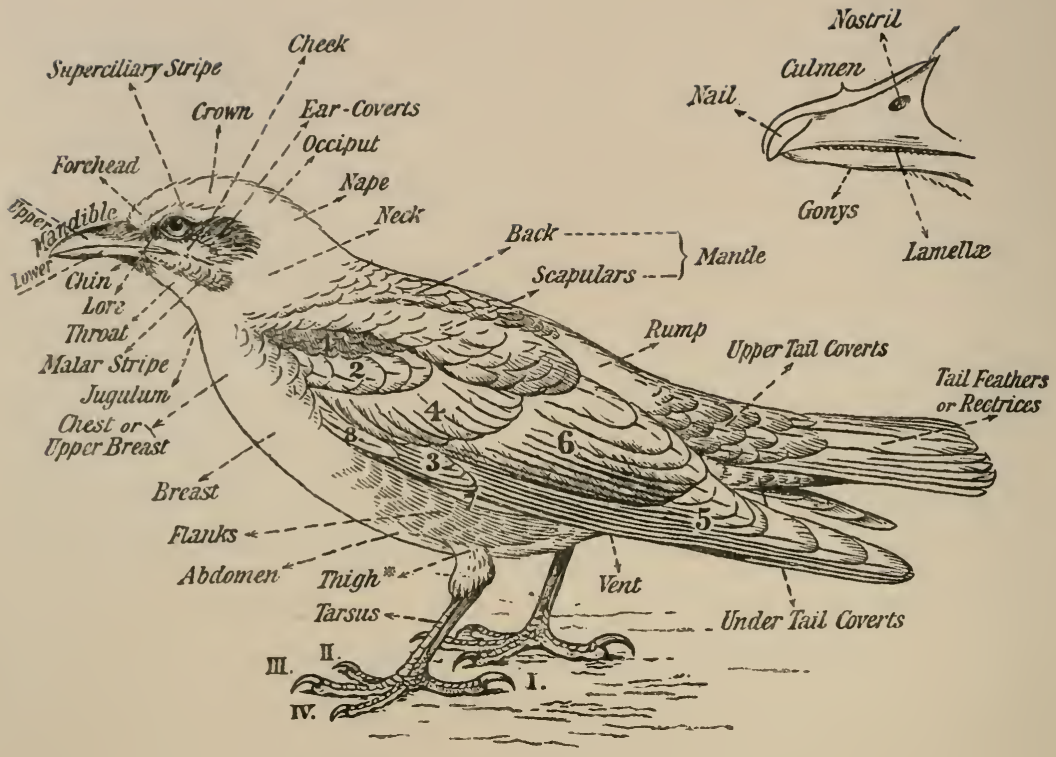

Diagram showing the Topography of a Bird. LEG. $\left\{\begin{array}{l}\text { Tarsus. } \\ \text { Ist or hind toe. } \\ \text { IInd or inner toe. } \\ \text { IIIrd or middle toe. } \\ \text { IVth or outer toe. }\end{array}\right.$

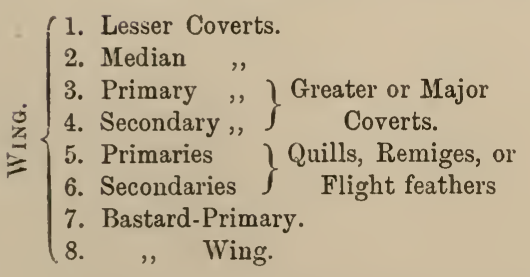

* This joint is the heel proper, but is commonly called the thigh. 


\section{BIRDS OF BRITAIN}

\section{THE MISSEL THRUSH}

\section{Turdus viscivorus, Linnæus}

IT was by the sea-coast, on a bleak and wind-swept hill covered with short grass and patches of heather and gorse, that our attention was first directed to a light-coloured bird of fair size which rose at our feet from behind a tussock, and uttering a curious wild churring note, darted away against the strong south-west wind. Well has he earned his name of "Storm Cock" from his wild note and rapid flight. Watch him now, sustained by quick, continuous wing-beats, and now as the wind slackens carried along with a dipping motion and outstretched wings, the whole bird suggestive of strength and activity, and as fickle and changeable in his moods as the elements among which he delights to live.

It was in June that I first saw him, when he and others of his kind, who but a few months before were callow and helpless nestlings, were learning from the summer gale a taste of what they would have to face when winter brought its storms and tempests, for the Storm Cock is no migrant to warmer climes and softer breezes, but leads a regular 


\section{Birds of Britain}

roving gipsy's life over our Islands, wandering from the northernmost corners of Scotland to the south of England, obeying no will but his own, and guided by no special impulse beyond that of satisfying his own appetite,-by no means a difficult task, as little in the way of berries or insects comes amiss to him. His common name of Missel Thrush (Mistletoe Thrush) is derived from his supposed fondness for this berry, but this is a point on which doubt still exists.

On the day when we first saw him, however, he was engaged in picking up the flies, ants, beetles, and other live prey which the scanty vegetation on the hill enabled him to see and capture easily. In spots where the ground was loose he would dig in his bill and turn over a small bit of earth, then stand with head held expectantly on one side, literally waiting for something to turn up. Often he would repeat this several times with little or no result, then all of a sudden down would go his head and we would make out something between his mandibles, then would come a quick movement of his head and his beak would be empty again.

Suddenly one of his brothers near uttered an alarm-note, and in an instant he was up and across the valley, where for the moment we could not follow him.

Thus, then, he spends his life from May till January: on cliffs by the sea, on bare moorlands, in thick woods-where the mountain-ash berries in their season form a favourite food-over open, cultivated fields where the freshly-turned furrow has unearthed abundant delicacies-or in the country hedgerow where hips and haws, elderberries and sloe are 


\section{The Missel Thrush}

not less appreciated. Here to-day and gone to-morrow, a restless, wandering bird.

As early as Jauuary, however, he begins to think of nesting, and having secured a mate, retires to what is for him a comparatively sheltered spot, either to a wood, or preferably to a row of trees along a hedge, and not unfrequently to some fruit-tree in an orchard or garden. Whether or not the Missel Thrush returns year after year to the same spot to nest we cannot say, but, as a rule, the same garden or row of trees will every spring shelter a pair of these birds if once they have nested there.

Although he may probably build his nest quite close to our house, yet the Missel Thrush is always wild and shy, and is rarely seen except as he flies over the garden uttering his unmistakable note, or as he sits on the topmost branch of some tall tree and sings his love-song to his mate below. The song is wild, and consists of a somewhat incoherent medley of notes, which, if not calculated to appeal especially to our musical ear, strikes at any rate a note of harmony with the winter's wind.

The nest is placed on a horizontal branch some 10 or 12 feet from the ground, and often at some distance from the trunk of the tree. The Missel Thrush is very conservative in its choice of a site, and seldom if ever chooses any other position. When built the nest is a fairly conspicuous object, with its foundation of twigs and mud and lined with grass and hay. Towards the end of February, however, we shall one day be surprised to see a large nest in some conspicuous position, and on examination will probably discover the hen, sitting on four to six eggs of a 


\section{Birds of Britain}

bluish colour with large reddish spots and blotches fairly evenly distributed over their surface. But even now, although we know exactly where the nest of these shy birds is, it will not be easy to see much of them.

When the young are hatched both parents attend most assiduously to the wants of the brood, feeding them on earth-worms, the favourite food of almost all the Thrushes. By the end of March the first brood is on the wing, and the parents busy themselves with a new nest for the reception of their second family. These, too, are hatched and on the wing by the middle of May, and then the whole family, young and old, leave their home to wander round the country until another January brings them back again to add their note of harmony to the winter's wind.

The upper parts are of a uniform ash brown, under parts buffish white thickly spotted with dark brown. The sexes are alike in plumage. The young has the upper parts spotted with buff, and the spots below are much smaller. Length 11 in.; wing 6 in.

\section{THE SONG THRUSH}

\section{Turdus musicus, Linnæus}

One of the first signs that winter is thinking of releasing its grasp, and that spring, if still some way off, is nevertheless on the way, is the clear melodious song of the Song Thrush. Soon after daybreak (having breakfasted off the early worm) this bird may be heard in almost every garden 

SONG THRUSH

Turdus musicus 


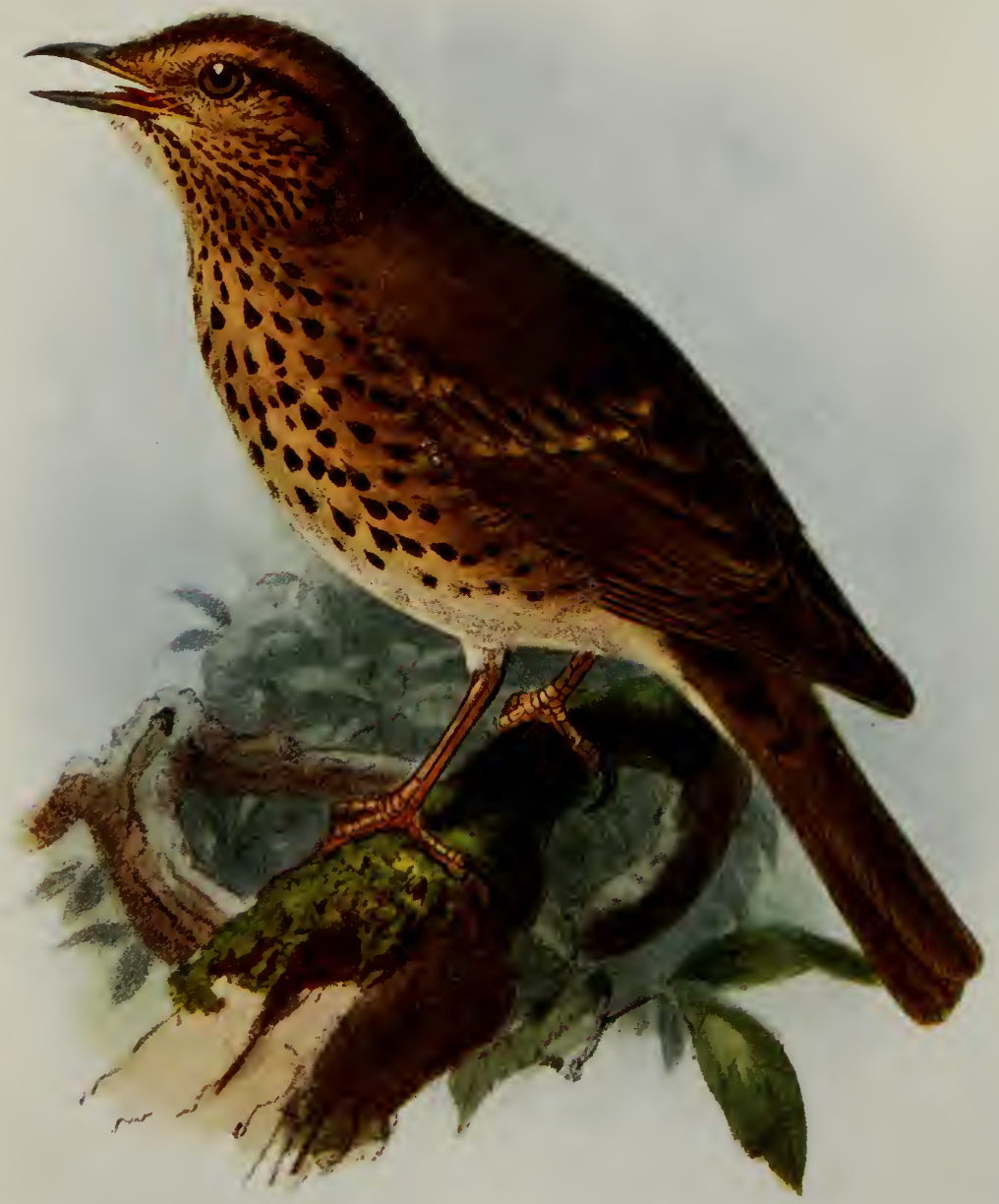





\section{The Song Thrush}

that can boast of a shrub large enough to conceal him and his nest. Any sort of cultivated country forms his home, either the broad fields, scanty hedgerows, the carefullycultivated garden of the wealthy, or even the small and dusty plot of the town-dweller.

His food consists chiefly of insects, though worms form a considerable part of his diet, and snails are a delicacy of which he is extremely fond.

There must be few people who have not noticed our brown friend hopping down the garden path with his peculiar sidelong leaps, now and then varied by two or three quick short steps as he conveys a snail to his favourite abattoir. This usually consists of a moderate-sized smooth stone, on which the unfortunate snail is beaten till his house falls from him; when this is accomplished there is a quick gulp, and he is gone! Thus refreshed, our friend will mount a near-by twig, clean his bill by rubbing it several times on either side of his perch, preen and shake out his feathers a bit, and then resting on one leg he will whistle his song, which has been rendered by some writers in the following words:- "Deal o' wet, deal o' wet, deal o' wet, I do, I do, I do. Who'd do it: Pretty Dick, Pretty Dick, Pretty Dick, Who'd do it." This will go on for some time until perhaps he happens to glance down at the lawn which he considers his especial preserve. Here he sees something which causes his song to cease in an instant. It is his rival openly flaunting himself before him. There is a swirl of wings as he rushes to the attack! They meet! Their bills snap violently, and there is every - prospect of a fight. Then suddenly the rival retreats pre- 


\section{Birds of Britain}

cipitately into the nearest bush, hotly pursued by our friend, and we have time to notice the peculiar way in which the tail and wings are spread as they disappear. Then we see no more.

Such is the life of one of our commonest birds as we may witness it any day in early spring. By the end of March, or even earlier, its nest may be found in some sheltered nook. It is not often more than 10 feet from the ground, and is generally in the fork of some tree or bush, or on the beam of some old barn or potting shed; perhaps it may be found in the middle of a hedgerow, or occasionally even on the ground. It is composed of rough grass and bents, and lined with mud pressed round and smoothed so as to form a fairly deep cup.

The eggs are five in number, and in colour are a beautiful pale blue, with a few small black or purplishmauve spots towards the larger end, these markings being in some cases entirely lacking. After a fortnight's incubation the young are hatched; they are then almost naked and only slightly covered with down.

Incubation is carried on by the hen alone, but both birds assist in the feeding, the diet consisting almost entirely of earth-worms. In about a fortnight to three weeks after the young are hatched they leave the nest to find and earn their own living, whilst their parents busy themselves with the cares of another family, for a pair of birds generally rears three broods in the season. After the rearing of the last brood, which is over by the end of June or early in July, both old and young begin to moult. Consequently, at this time of year they are very quiet and skulking in their 


\section{The Song Thrush}

habits, but we may sometimes catch sight of them in the evenings and early mornings when they come out to feed on lawns and fields where the grass is short and where their favourite earth-worms abound. About the end of August a close observer will often miss his little friend for a few days or even weeks. Then one morning he will again see the familiar figure on the lawn and think that perhaps his companion has returned. But it is not so. The spring visitor has gone to another part of the country, probably not very far away, as this species is only a partial migrant, but nevertheless he has gone, and the bird which has taken his place has come from some more northerly locality to spend the winter. Probably we do not notice the change, and put down the temporary disappearance of our particular Song Thrush to the fact that we chanced not to see him. It is not so, however, for our friend of spring and summer has departed.

The general colour above, including mantle and wings, is uniform olive brown, some of the major and median covers having buffish tips. Breast yellowish, spotted with triangular olive-brown spots, the flanks uniformly olive, chin and throat white, margined with a row of dark streaks. Belly white. Bill brown, base of lower mandible paler. Legs pale flesh. Iris hazel. Length $9 \cdot 0$ in.; wing $4 \cdot 6 \mathrm{in.}$

Young birds are spotted on the upper parts. This species is widely and generally distributed throughout the British Isles. 


\section{Birds of Britain}

\section{THE REDWING}

\section{Turdus iliacus, Linnæus}

From the middle to the end of October, when the leaves are falling thickly from the trees, and the dull, dark days of winter are beginning to make themselves felt, we may be aware, while walking along a country lane or through a park, of a new arrival among our birds. There rises, probably from the ground, a dark-coloured bird, whose quick movement will at once catch our eye, and being in company with others similar to himself, we shall have no difficulty in recognising the Redwing. Tired possibly by his long journey, he will settle on the hedge a little in front of us, and begin diligently feeding on any berries he can find, as but little in that line comes amiss to our friend; and soon he will again drop to the ground, and we shall get a glimpse of the deep red feathers under his wings from which he has derived his trivial name. At this season of the year Redwings are essentially wanderers, moving about in flocks of from a dozen to thirty or more, stopping here and there where food is plentiful for a few days or weeks, and then moving on, always southward, as lack of food or the severity of the weather dictates. If the winter be mild, they may be found roosting in large numbers in thick hawthorn hedges or small plantations; for although fond of cover, and spending most of their time among undergrowth on the ground, they are not very partial to large woods, preferring thick hedgerows or small coppices. 


\section{The Redwing}

A cold north wind, accompanied by snow and frost, drives most of these birds away from our shores to sunnier climes: their place, however, is soon taken, if the hard weather be prolonged, by large immigrations of poor storm-driven birds from the north of the Continent, who reach us with barely sufficient strength to seek their food, and who receive, too frequently, an inhospitable reception. Such wanderers become exceedingly tame, and may be found hopping disconsolately round our gardens within a foot or two of us, and the mortality in such seasons as these must be very great. Happily this extreme severity does not often happen, and one is glad to think that as a rule our visitors, driven to us by hard weather abroad, find sustenance in our warmer, if still somewhat boisterous, climate.

In April, that strange homing instinct which animates almost every known bird, causes the Redwings to leave our hedgerows at their most beautiful time, and to seek a northern home where they may settle down and rear their young. There, where song-birds are scarce, his little warble, which would be unnoticed here in our wealth of songsters, is eagerly awaited, and eulogised as though it were the rich outpourings of a nightingale. His nest is built on the ground, or just above it at the foot of some bush, or even in a crevice a short distance up the trunk of a tree; but if so far north as to be beyond the limit of tree growth, a sloping bank or the shelter of some boulder will be selected as the site. The nest is substantially built of grass with a foundation of twigs, and is similar to that of our Blackbird, to which species also the eggs, though slightly smaller, bear a close resemblance. Two broods are sometimes reared in 


\section{Birds of Britain}

the season, especially in the more southerly parts of its breeding range, and after the duties of family life are over, the birds unite in small flocks, lingering in their northern home till autumnal storms drive them once more among us.

The male in winter is uniform olive brown above. Chest and chin pale buff, thickly and irregularly streaked with dark brown. Sides of face dark brown, a light buffish or white superciliary streak running from the base of the upper mandible over the eye. Flanks deep rich chestnut; remainder of lower parts white, slightly streaked on the sides with olive brown. Bill dark horn colour, legs pale flesh. Length 8.75 in.; wing 4.4 in. The sexes are similar in plumage, but the fermale is paler and duller in colour than the male. The young bird is spotted on the back, and after the autumn moult may still be recognised by the pale tips to the wing coverts.

Its breeding range extends north of $54^{\circ}$ from the Yenesei westward to Scandinavia, and its breeding in our islands has not as yet been authenticated. In winter it is found throughout the south of Europe, extending eastwards through Persia and Turkestan.

\section{THE FIELDFARE}

Turdus pilaris, Linnæus

An unwonted note strikes our ears, a sort of "chack" or "chick," and looking round we see that it proceeds from a flock 'of ten or a dozen birds flying on a straight course 



\section{FIELDFARE}

Turdus pilaris

Adult (left and centre). Young (right) 


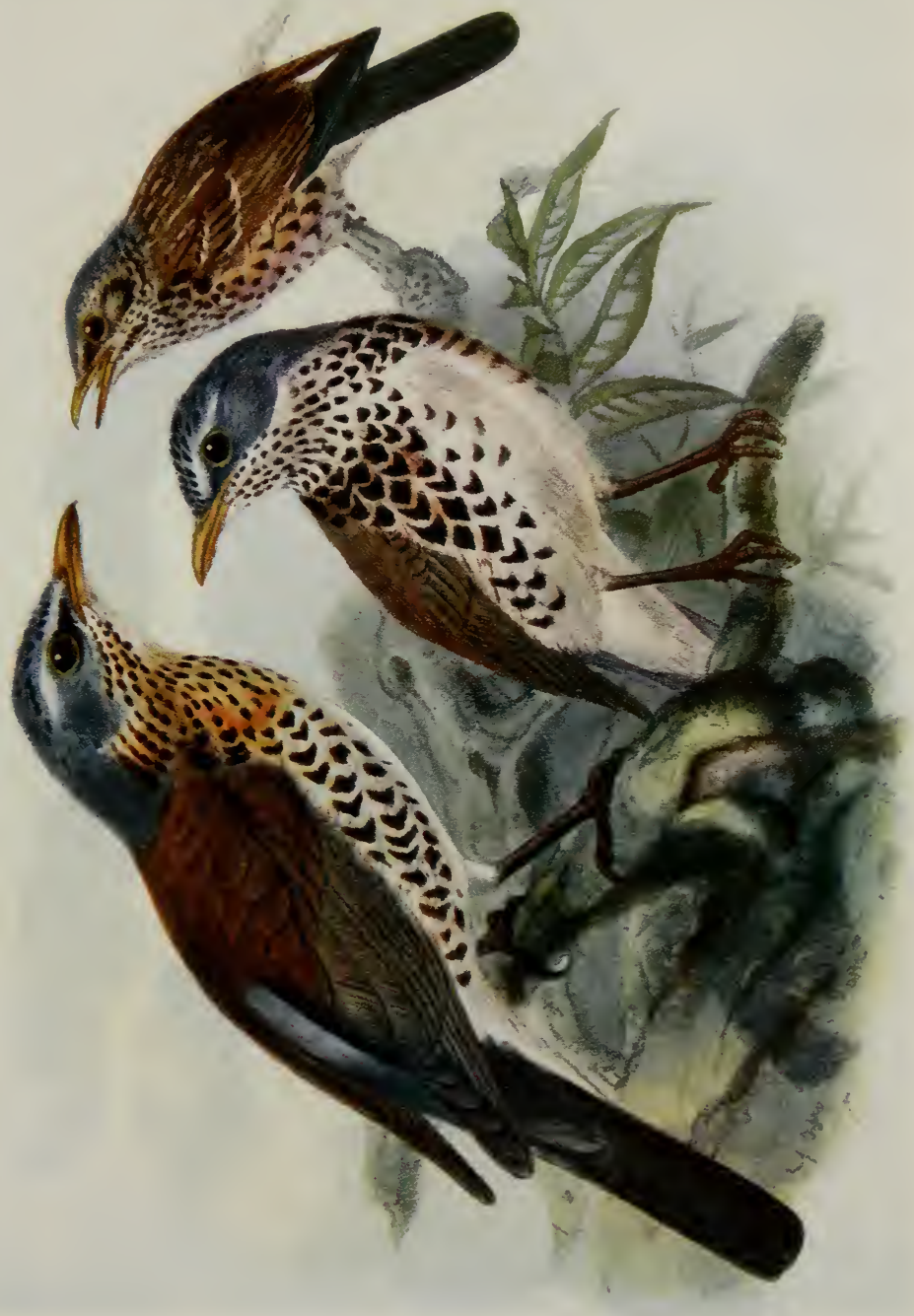





\section{The Fieldfare}

high in the air, with quick and regular wing-beats. At first sight they appear like Missel Thrushes, but their flight is less erratic, and their unmistakable note tells us that the last of our migrant Thrushes has arrived to spend the winter with us. Like the Redwing, the Fieldfare is emphatically a bird of the North, although, as he always nests in trees, he does not touch high latitudes, like the Redwing, being restrained in that direction by the limit of tree growth. In summer the woods of the far north form his home, and, as if he himself felt the solitude and intense stillness that reigns there, he breeds generally in small colonies of from ten to a dozen pairs. The nests are generally placed in the first fork of a birch tree, from 4 to 8 feet above the ground. The eggs closely resemble those of the Missel Thrush, but are rather smaller. The Fieldfare's song is very feeble, and consists of an incoherent warble, varied with the "chack, chack" of his call-note. However he is not the only denizen of the woods that feels the need of companionship, as it will generally be found that a few pairs of Redwings have also nested near the colony, and their more melodious song is an added element of cheerfulness. Amid such surroundings the young Fieldfare is hatched, and is carefully tended by his parents, who supply him with worms, insects, beetles, and in fact any small living thing that they can capture. They are most bold and noisy in defence of their young, flying close round an intruder's head, and uttering their alarm-note unceasingly. The young bird being duly fledged, leaves his nest, and in company with others of his own age wanders about the woods, feeding on insects or any fruit he can find; while 


\section{Birds of Britain}

his parents, to make the most of the short summer, busy themselves with the cares of a second brood. It is not until the first storms and snows of winter come that the Fieldfare leaves his summer home, though during the few weeks that have elapsed since he left the nest he may have wandered aimlessly far from his birthplace. The chill mists of autumn, however, remind him that he must move south, so reluctantly, as if clinging to the edge of winter, he finally takes flight, and we in England hear his "chack, chack" towards the end of October, his numbers being continually augmented as each fresh northerly blast drives some of his kind farther and farther south. While with us, as he is essentially a sociable bird, he attaches himself to wandering flocks of Missel Thrushes and Redwings, and among the former he may always be distinguished by his light-coloured rump, which shows up conspicuously against the darker wings and mantle. Thus he wanders the whole winter through, feeding chiefly on the hips and haws in the hedges, and probably also on worms and grubs, for he may frequently be met with in ploughed fields. At night, with much "chacking," he goes to roost in some thick hedge, coppice, or plantation, where, in company with the Missel Thrushes, he will seek the highest branches, while the Redwing roosts in the thicker growth below. In hard weather he does not seem to suffer like the Redwing, possibly from his marked preference for berries, which even the heaviest snow does not cover. It would seem as if the long journeys which he has to take were distasteful to him, for summer is nearly with us before the last Fieldfares have left our shores, as not uncommonly they may be seen until 


\section{The Fieldfare}

the middle of May; or perchance he knows that the inhospitable climate, to which he resorts to breed, driven by some irresistible and incomprehensible force, will not till then afford him and his progeny the necessary sustenance. Be that as it may, we can still hear his cheery voice long after we have left winter behind us.

The sexes are alike in plumage, but the female is rather paler in colouring. The adult male in winter has the head and neck slate grey, the feathers of the crown having dark centres which are hardly noticeable at this season; mantle and scapulars deep rufous brown; wing coverts less rufous and showing traces of paler tips. Rump grey; quills and tail dark brown. Fore-neck pale yellow, streaked with dark brown on the sides; chest rufous streaked with brown; flank feathers dark brown with broad white margins concealing the darker colour. Lower breast and chest white. In summer the pale edgings to the under parts wear off, causing him to become nearly black on the flanks and lower breast, while the dark streaks on the crown become much more conspicuous. Bill horn coloured in winter, yellow in summer. Legs and feet dark brown. Total length 10 in.; wing $5.5 \mathrm{in}$. The plumage of the young bird resembles that of the adult on the back, but the head and rump are much browner; some of the feathers of the mantle have lightish centres, though the amount and extent of these varies greatly. Below it is of a uniform pale yellow, deeper on the breast, each feather having a black terminal heartshaped spot.

This species is generally distributed throughout the British Isles from October to May; breeding throughout 


\section{Birds of Britain}

Scandinavia, Russia, and Siberia as far east as the Lena. It does not, as a rule, nest south of the Baltic, though there are said to be isolated colonies in the high mountain regions of Central Europe, the Alps, and the Pyrenees. Its winter migrations extend throughout the whole of Southern Europe and Asia Minor, including both sides of the Mediterranean basin.

\section{THE BLACK-THROATED THRUSH}

Turdus atrigularis, Temminck

This is an Eastern species, breeding in Siberia from the Ural Mountains eastwards, and wintering in Persia, Afghanistan, and India. Stragglers have frequently been obtained in Europe, and two or three examples have been taken in these islands.

The adult is brown on the upper parts and whitish below, except for the chin, which is spotted, and the throat and breast, which are black. Length 9.75 in.; wing 5.45 in.

\section{WHITE'S THRUSH}

\section{Turdus varius, Pallas}

A large Thrush, rather bigger than a Missel Thrush, and not unlike that species in its immature plumage. It is of extremely rare occurrence on our islands, and has only 


\section{White's Thrush}

been obtained in about eight or nine counties of England, and on three occasions in Ireland.

Young Missel Thrushes have been frequently recorded as belonging to this species. White's Thrush may, however, always be distinguished by having fourteen tail feathers instead of twelve, and the under side of the wing, which in the Missel Thrush is pure white, has in this species a broad black bar across the centre.

Its summer home lies across Siberia, east of the Yenesei, through Northern China and Japan, whence it migrates in winter to South China and the Philippines.

\section{THE BLACKBIRD}

\section{Turdus merula, Linnæus}

Mingling with the Song Thrushes on the lawn, but always recognisable by his much longer tail and darker colour, we may at all times of the year see the Blackbird. $\mathrm{He}$ is hardly so familiar as his neighbour the Thrush, and prefers to keep near the shrubbery, where, on the least sign of real or imaginary danger, he may retire, and by remaining motionless be secure from observation; but if we follow him, and approach too near, he will fly away, uttering his loud alarm-note of "Cluck, cluck!" He will not be long away, however, and if we remain quiet he will soon be back again, crossing the lawn with long, measured hops, stopping now and again to look round and to spread and "flirt" his broad fanshaped tail. The Missel Thrush will be sitting on the eggs, and 


\section{Birds of Britain}

the Song Thrush will have nearly completed her nest, before our sable friend begins to think of matrimonial cares. Towards the end of February his clear flute-like notes will be heard from the shrubbery or hedgerow-a song which, if more mellow in tone, is far shorter and more monotonous than that of the Song Thrush, although the performance of some individual Blackbirds is longer and more pleasing. $\mathrm{He}$ will now sing almost continuously, with the exception of a few short intervals spent in chasing his mate, who, unlike him, wears a dull suit of russet brown. And he will have to prove himself a preux chevalier ere he can win his lady fair, for there will almost certainly be two or three other suitors to fight, and the victor alone can claim the lady, while the ousted competitors retire from the field. This extreme combativeness makes the species appear scarcer than is really the case, as each pair will claim suzerain rights over a comparatively large space. The nest is built low down in some bush or hedgerow, on the ground in a bank, in a furze bush or on a heath, and is formed entirely of grass and bents, with a little mud for the foundation, but well lined with finer bents; it is rather larger in diameter, and shallower, than that of the Thrush. The eggs, four to six in number, have a pale blue ground colour, thickly mottled with reddish markings, sometimes uniformly distributed over its surface, at others confined to broader blotches forming a ring round its larger end, or again, in some cases, the markings may be entirely absent. The young, like those of most Thrushes, are fed almost entirely on earthworms, though insects are also swallowed; two or three broods are reared in the season, and as summer advances 


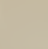


BLACKBIRD

Turdus merula

Adult male (centre!. Adult female (right). Young (left) 


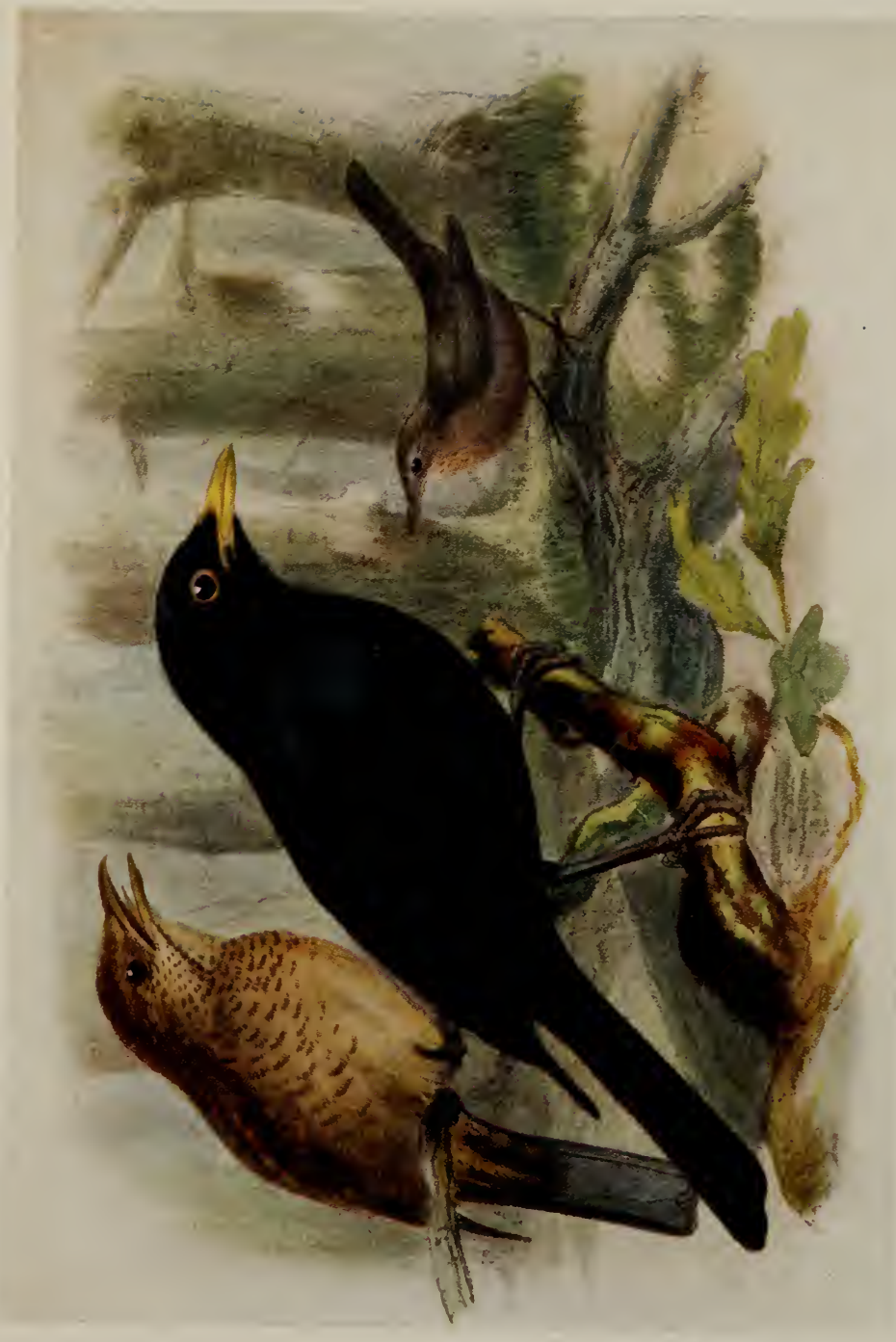





\section{The Blackbird}

and fruit ripens, visits are paid to the neighbouring orchards and gardens, the spoils from which form, during the season, a very large proportion of their diet, so there is no doubt that the gardeners' complaints of them are only too well justified. With the advent of the migration season in September and October large numbers leave our shores, only, we fear, to be caught and eaten by our neighbours across the Channel, where members of the Thrush family are considered great delicacies. Many however remain, spending the winter in thick hedgerows, shrubberies, and woods, or anywhere in fact where there is a bush high enough to shelter them. Furze-covered commons are favourite localities, as are also the open heather-covered tops of low hills.

Our friends, however, do not all follow the laws of migration; some do not leave the neighbourhood of their home, unless driven away by stronger rivals. And so it happens that year by year, as winter relaxes its grasp, we can see our orange-billed friend on his accustomed perch in hedge or bush singing away in full consciousness that his own power has earned him the right to do so, and quite prepared to defend it again and again, till in course of time he is ousted by another minstrel, who reigns in his stead by the law that "might is right." The Blackbirds found migrating along our shores are either the surplus population, driven farther afield by competition, or wanderers from the colder parts of the Continent of Europe from which it regularly migrates.

The male is of a uniform deep glossy black, with bright orange bill. Legs and feet black. Iris hazel. Young 


\section{Birds of Britain}

males in their first winter have a black bill. Total length $10.1 \mathrm{in}$; wing $5 \mathrm{in}$.

The female is of a uniform dull sooty brown above; chin greyish, with dark brown streaks; chest reddish brown, each feather with a darker tip, giving it a mottled appearance. Flanks dark brown, sometimes mottled with lighter. Vent sooty grey.

The young of both sexes resemble the female in general appearance, but the feathers of the head and back have light shafts. Young males are a shade darker in colour. Generally distributed throughout the British Isles, except Shetland and the Outer Hebrides, where it only occurs on migration.

\section{THE DUSKY THRUSH}

Turdus dubius, Bechstein

This species breeds in Eastern Siberia, from the valley of the Yenesei to the Pacific. Several stragglers have been obtained at different times in Europe, but the only British example was shot in 1905 near Gunthorpe, Notts.

The general colour is greyish brown above, streaked with darker, becoming more rufous on the rump. Quills broadly margined with rufous. Below white, breast and flanks boldly marked with black; under wing coverts and axillaries rufous. 


\section{The Ring Ouzel}

\section{THE RING OUZEL}

Turdus torquatus (Linnæus)

"Chuck, chuck"—“chuck, chuck, chuck!" The note is strangely reminiscent of the Fieldfare, but it is now June, and even the latest stragglers of that species have left us. We are on a hillside in Wales, below us lies the Irish Channel, with hardly a ripple on its surface, the hill itself is almost covered with a short growth of furze and heather, the intervening spaces being carpeted with short moss and grass, kept well cropped by the hardy race of sheep for which the Principality is justly famous. "Chuck, chuck" - this time we catch a glimpse of the bird, the beautiful white half-moon on his breast showing up clearly against the black of the rest of his plumage as he sits on one of the boulders that project through the vegetation and refuse to be hidden. He rises, and making a swift semicircular flight, pitches on another point of vantage, whilst the hen also appears and regards us with anxiety. However, as we stay still, she presently disappears, and he, ceasing his monotonous note, hops behind a tussock of grass, and all is quiet. Suddenly he reappears with a fine insect in his beak; we are still regarded with suspicion, and the clucking note is often repeated as he flies round us several times, continually settling for a few seconds to make sure whether our presence is for good or ill before he betrays the whereabouts of his nest, the all-absorbing interest of his life at the present time. Soon he takes another flight, and we lose sight of him as 


\section{Birds of Britain}

he disappears in a small gully. Following quickly we are just able to see his mate come from the steep side of the ravine, and almost simultaneously he appears and joins her in fluttering round us in a terrible state of agitation, and doubtless with a feeling that had he been more patient we should have gone away without finding his home. As, however, his cries produce no effect, he flies off and settles some distance away. A few feet down the bank, and cunningly hidden near a sheep-path, underneath an overhanging tuft, is the nest, built almost entirely of grass and bents, as is the case with most of the Thrushes, but with little or no mud. The young, four in number, being well grown, scramble out of the nest, calling out at the same time, and bringing their parents round us again, more vociferous than ever. We have, however, no evil intentions, and having satisfied our curiosity we continue our walk. Suddenly a bird rises from behind a stone at our feet, flies a few yards, and disappears round another boulder, this action is repeated several times, till finally, becoming really alarmed, he flies rapidly away over the spur of the hill. His plumage is uniformly dark, just a little lighter on the breast, and we recognise (if we did not already know it) a young bird strongly on the wing; a few yards farther on we see a hen bird, possibly his mother; she leaves her nest with four eggs, which much resemble those of a Blackbird. The nest was placed on the ground, under the shelter of a bramble. On all the moorlands and hills of the British Isles this Ring Ouzel may be found during the summer, nesting either as already described, or in holes of old walls, barns, or in fact wherever a spot can be found well concealed and 

RING OUZEL

Turdus torquatus

Aclult male (left). Adult female (above). Young (right) 


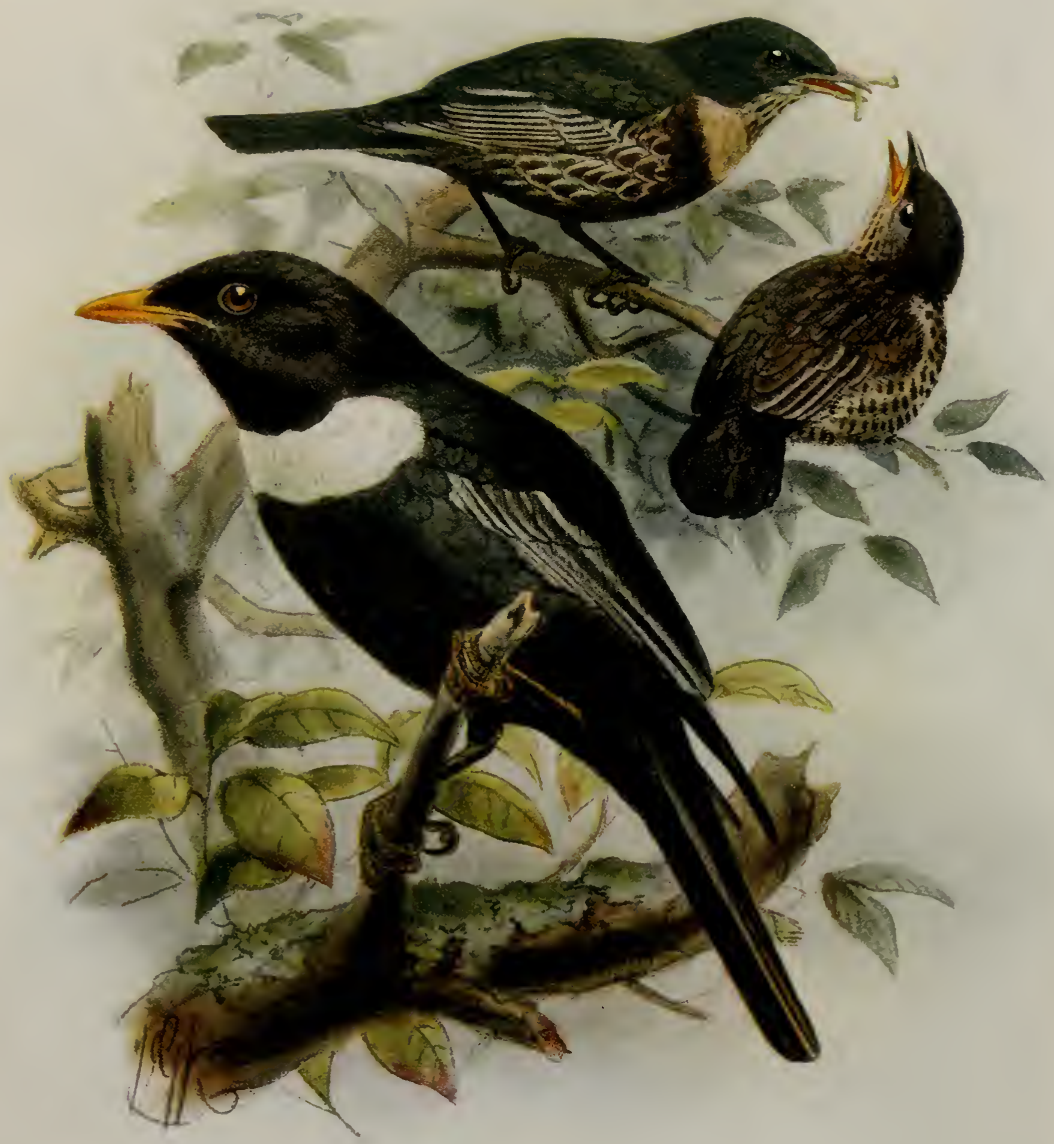





\section{The Ring Ouzel}

sheltered from the wind. Towards the end of September he leaves his summer home and is then generally distributed throughout the country, although often overlooked owing to his resemblance to a Blackbird when seen from a short distance. Watch him, however, till he settles, for when alarmed he invariably perches on the top of the hedge before dropping down the other side, while the Blackbird, with his characteristic motion of the tail, enters the hedge at once low down on the near side. The Ring Ouzel is not at home in the cultivated lowlands, and by the end of October they have all left the country.

In Cornwall and Devon they reappear again at the end of February, and working their way northwards through Wales, commence to nest early in April, as soon as spring has made itself felt on the hills. A few may spend the winter in our most south-western counties, and it is probable that our home-bred birds travel entirely by a western route, and that the birds met with in the east and southeast of the country are all foreign bred, for till the end of April birds are found still pursuing their northward journey to lands beyond ours.

The general colour of the upper parts is brownish black, with lighter margins to the wing coverts. Under parts brownish black with broad white crescentic gorget. The female is lighter, and has a narrow gorget. In autumn both sexes have the feathers margined with grey. Length 10 in. ; wing $5 \cdot 5$ in. 


\section{Birds of Britain}

\section{THE ROCK THRUSH}

\section{Monticola saxatilis (Linnæus)}

The Rock Thrush is an Eastern species that breeds sparingly from Central Europe eastwards through Southern Siberia and North China, and southwards in Greece, the Balkans, Asia Minor, and Persia. It has only once been obtained in our islands, namely in Hertfordshire in 1843.

The male is greyish blue on the head, neck, and mantle; white on the rump, tail and under parts bright chestnut. The female is speckled brown above, chin and throat whitish, breast and under parts buff mottled with brown. Length 7.5 in.; wing 4.75 in.

\section{THE WHEATEAR}

\section{Saxicola œnanthe (Linnæus)}

Before the March winds have subsided, and while the trees and all vegetation are still in their winter sleep, the first of the Wheatears appears in the south-west of England. A lively and sprightly little chap is he, as he sits on a tussock of grass or on a fence, jerking his tail, or darting with a quick sharp flight to some other elevation, showing, as he does so, his conspicuous white rump, while his dark wing feathers and tail and grey back prevent the passer-by from mistaking him for any other species. $\mathrm{He}$ is a bird of the open, preferring large sandy stretches or wide moorlands, 

WHEATEAR

Saxicola ananthe

Adult male (right). Female (centre). Young in autumn (left). 


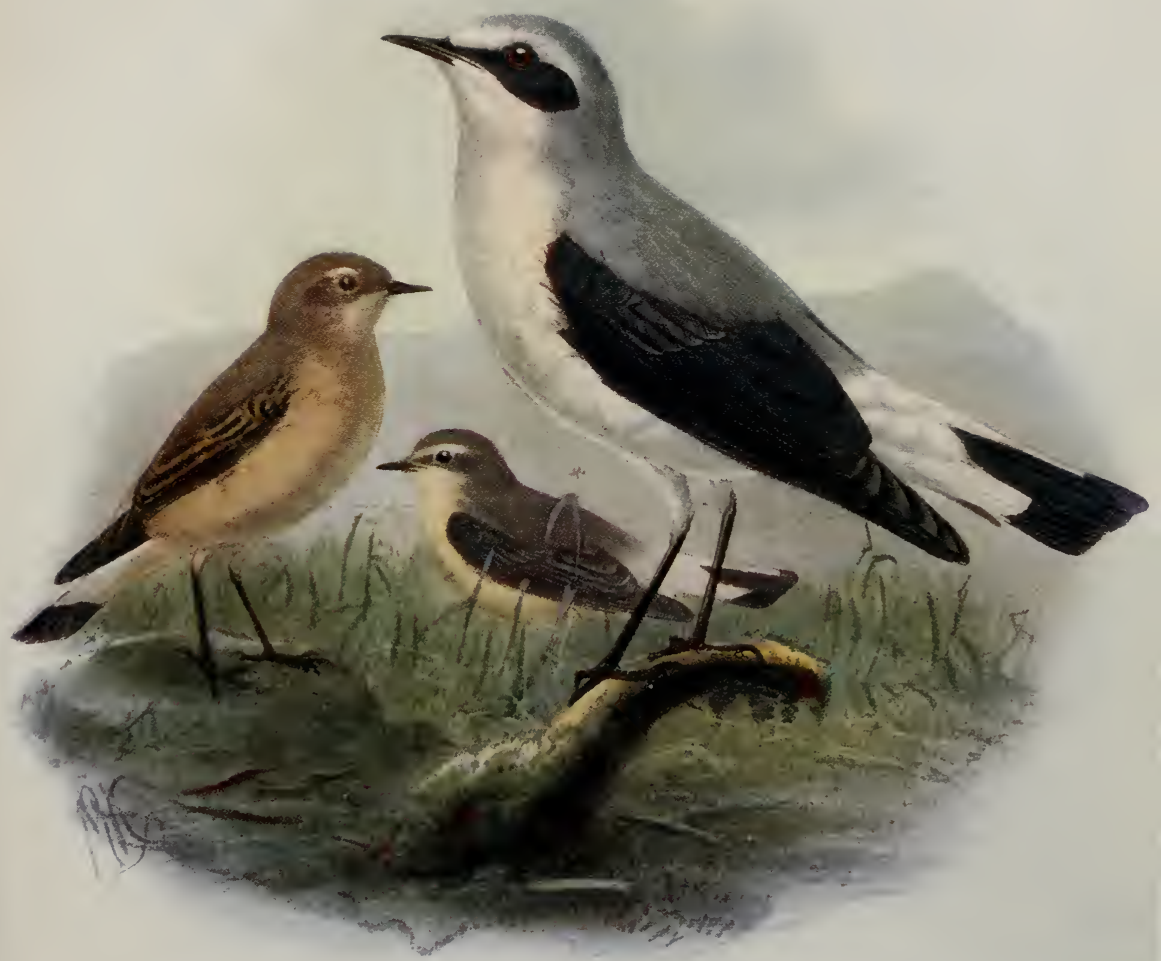





\section{The Wheatear}

and it is only during migration that he affects woodlands and the more cultivated districts. As a rule the male birds are the first to arrive, being followed in about a week or ten days by the hens and less vigorous males. Having chosen his mate, about the first or second week in April, he will begin to look for a nesting-site, generally a little way down a rabbit-burrow, or in moorland districts a hole or crevice of a rock or stone wall will be chosen, but wherever placed it will be secure from observation. The nest is loosely built of grass, moss, rabbit fleck, fur, and feathers, or any material that comes handy, and having laid six or seven eggs of a uniform pale-blue colour the hen commences her business of incubation, in which the cock takes no part. $\mathrm{He}$ is, however, in constant attendance in the vicinity of the nest, frequently uttering his apology for a song, which consists merely of a few notes carelessly strung together, singing apparently rather from exuberance of spirits than because he really appreciates music, for often, as a spider or other insect comes within his range of vision, he will suddenly break off his song, seize the tempting morsel, and fly up again with his sharp "chack, chack." The nest is somewhat difficult to find, and as a rule can only be discovered by watching the hen bird, who may be recognised by her browner tints; if, however, she suspects you of watching her, she will refuse to return for some considerable time. If you allow your attention to be diverted, she will seize the opportunity to dart home, and your trouble will have been in vain. With the wants, however, of six children to attend to, she will betray less caution; both parents then look after the young, and they may be watched with 


\section{Birds of Britain}

comparative ease, as, having secured a luscious beakful of insects, spiders especially being a great delicacy, they hop or dart with their peculiar sharp flight from point to point, till finally they are gone, and on approaching the spot where they vanished, you will suddenly see them reappear from some hole or cranny.

The young leave the nest as soon as they are able to hop and flutter, and are then jealously guarded by their parents, who fly round in great excitement if you approach too near. They are soon well on the wing, however, and the old birds are free to burden themselves with another family. During the early part of May, a large variety of the Wheatear may sometimes be seen, most frequently along the sea-shore ; these are birds whose home is in the Far North, and which regularly pass through these islands at this time. They are larger and finer birds which have wintered in Africa and have remained on in Southern climes, refusing to be lured away when their English brethren left, but, judging their time as accurately as though possessed of the most reliable of calendars, they leave their tropical winter home when spring in temperate regions has well advanced. Not to be tempted by the attractions our country can offer in its most delightful month, they pursue their journey with restless energy to the apparently inhospitable shores of Greenland. These wanderers, however, do not concern us much; they are gone, and our summer residents are busy with their second brood, and when this is hatched, young and old spend the rest of the warm weather in their home; renewing their plumage, and preparing themselves for the shortening days of autumn, when they pass away to the 


\section{The Wheatear}

sunny shores of the Mediterranean and to North Africa, though a few stragglers may possibly be found during the winter in some warm and sheltered nook of Cornwall or Devon. They have gone-October has brought the cold weather, trees are rapidly becoming bare-we go out one morning and find to our surprise that apparently our summer friend has returned; by the next morning he is gone again, and we realise that these passing birds had only stopped to rest before undertaking another night stage on their long journey from the Arctic.

The male is grey on the head, neck, and back; wings black; rump, forehead, and superciliary streak white; lores and ear coverts black. Tail feathers, except the two central ones, which are black, white with broad black tips; underparts white, buffish on the throat and breast; under wing coverts mottled with dark grey and white. The female is brown on the back and ear coverts and much more buff below. The young are greyer and spotted above and below with buff. Length (of small race) 6 in.; wing 3.75 in.

\section{THE ISABELLINE WHEATEAR}

\section{Saxicola isabellina, Riuppell}

This is a south-eastern species inhabiting the plains of South Russia and Asia Minor in summer, and being a permanent resident in Palestine, Egypt, and East Africa. Only one example has been known in Western Europe; it was shot in Cumberland on November 11, 1887. 


\section{Birds of Britain}

This species very closely resembles the Common Wheatear, but may be distinguished as follows: It is more tawny, has more black in its tail, and the under wing coverts are white. Length 6.5 in.; wing 3.9 in.

\section{THE BLACK-EARED WHEATEAR}

Saxicola stapazina (Linnæus) nec Vieillot

The home of this species is in Southern Europe and North Africa. It has occurred in Sussex on three occasions during both the autumn and spring migrations.

Frontal line, lores, and a large patch extending backwards beyond the ear coverts, wings and wing coverts, black; mantle and breast rufous, rest of the plumage including the throat white. In the female the black is replaced by brownish and the upper parts are brownish grey. Length about 5 in.; wing 3.5 in.

(N.B.-The name stapazina has, until recently, been used for the next species, whose proper name is occidentalis.)

\section{THE BLACK-THROATED WHEATEAR}

\section{Saxicola occidentalis, Salvadori}

This is a very common summer visitor to the south of Europe, breeding regularly in France as far north as the Loire. It has occurred here on two or three occasions only. 


\section{The Black-throated Wheatear}

In the male the crown and upper back are golden buff; wings black; under parts pale buffish white; under wing coverts black. The female is duller and browner. Length 5.6 in. ; wing 3.5 in.

\section{THE DESERT WHEATEAR}

\section{Saxicola deserti, Rüppell}

This, as its name implies, is a southern desert species and is found widely distributed throughout North Africa and Egypt, to Persia and Afghanistan. It has been taken in Great Britain on at least three occasions-twice in Scotland and once in Yorkshire. It somewhat resembles the preceding species, but may always be distinguished by its tail, which is black almost to the base. Length 5.6 in.; wing 3.6 in.

\section{THE WHINCHAT}

\section{Pratincola rubetra (Linnæus)}

A merry little fellow is he, arriving in this country with our other summer migrants about the middle of April. His haunts are open fields and pastures, so that he does not often come across his near relation the Stonechat, whom in actions, and to some extent in dress, he clearly resembles.

You will generally first have your attention drawn to 


\section{Birds of Britain}

him by hearing his well-known note of " $u$-tick" as you walk across the field, and looking round you will see a small thick-set bird, hanging on to some slender stem which happens to be taller than its fellows; if you approach nearer he will fly a little farther on and settle again. His flight, and the habit of settling on some outstanding stem or spray, is very reminiscent of the Stonechat, but in spring his much paler breast and dark-striped head and buffish face will prevent any confusion. The hens and the young more closely approach in general appearance to the allied species, but the lesser amount of white on the tail and on the head may generally be noted.

Soon after they arrive the nest is begun; this is built on the ground, either under a tussock of grass, or more preferably, if possible, in a sloping bank. It is loosely constructed of grass and bents, and lined with horse hair. The eggs, six or even seven in number, are pale blue, very like those of the Stonechat, but bluer and with less of a greenish hue; as a rule they are absolutely unspotted, but occasionally a few minute rusty specks are present at the larger end. The hen alone sits, but both parents attend to the young. As soon as the first brood is on the wing, generally by the end of May, the parent birds busy themselves with the cares of another family, after which they wander about the open and unenclosed country, till, at the end of August and during the first half of September, they leave our shores for the summer regions of the south.

The male has the upper parts dark brown, mottled with buff. There is a clear, white, superciliary streak; tail feathers dark brown with white bases; wings brown, 28 


\section{The Whinchat}

showing a conspicuous white patch near the body. Under parts bright fawn colour, turning to buff on the belly. The female is similar, but paler and duller; the young resemble the hen, but are slightly spotted on the breast. Length $5 \cdot 25$ in. ; wing 3 in.

The species is generally distributed in England, except on the south-west, where it only occurs on migration. In Scotland it is local but widely distributed. In Ireland it breeds in the north, but only occurs in the south on migration.

\section{THE STONECHAT}

\section{Pratincola rubicola (Linnæus)}

On any rough common, where furze or tangles of bramble form almost the only cover, you may see the Stonechat; summer and winter alike he is there, brightening with his deep chestnut breast and jet-black head and back the otherwise comparatively lifeless spot.

You cannot miss him, or rather, he will not miss you, for as you approach he will rise and settle on the topmost spray of some furze bush, or possibly on the tall stem of grass or thistle.

Jerking his tail with the quivering movement characteristic of his tribe, as though it were on a spring, or uttering his little call of "Tick, tick," he will move ahead with dipping flight to some other point of vantage as you approach, and display as he does so the white on his tail and wings. A bright and happy little chap he is! Living 


\section{Birds of Britain}

in the open country-side the whole year through, finding there plenty of food, which consists chiefly of caterpillars and other insects, even in our inhospitable winters. Early in April he chooses his mate and sets up housekeeping: the nest, which is loosely built of grass and moss and lined with hair, is very well concealed, being placed near the ground in the centre of a clump of furze or bramble. There, protected by the natural chevaux de frise, the six pure blue eggs are laid, and in due course the young are hatched. The male does not sit, but is always to be seen in the vicinity of the nest, and continually brings tit-bits to his mate. Both parents tend the young with great care, and after they have left the nest the family may often be found wandering about together, the male on the approach of danger sitting on the topmost sprays of some bush, while his family remain concealed in the cover, following him singly or two or three at a time as he moves on. A second brood is generally reared in the season, and in autumn, after the moult, a certain amount of wandering takes place, generally in family parties, and at such times we may frequently find them in turnip fields, or on the edge of thick hedgerows, in cultivated country. These wanderings, however, do not generally extend to any great distance from their true home, to which, or to some neighbouring common, they return to spend the winter.

The plumage of the young is brown. The full-grown female resembles the male except that the colouring is less brilliant, and the white markings are not so conspicuous. The male has the head, throat, and back black; a patch on either side of the neck white; tail and wings dark 



\section{STONECHAT}

Pratincola nubicola

Male (right). Female (left) 


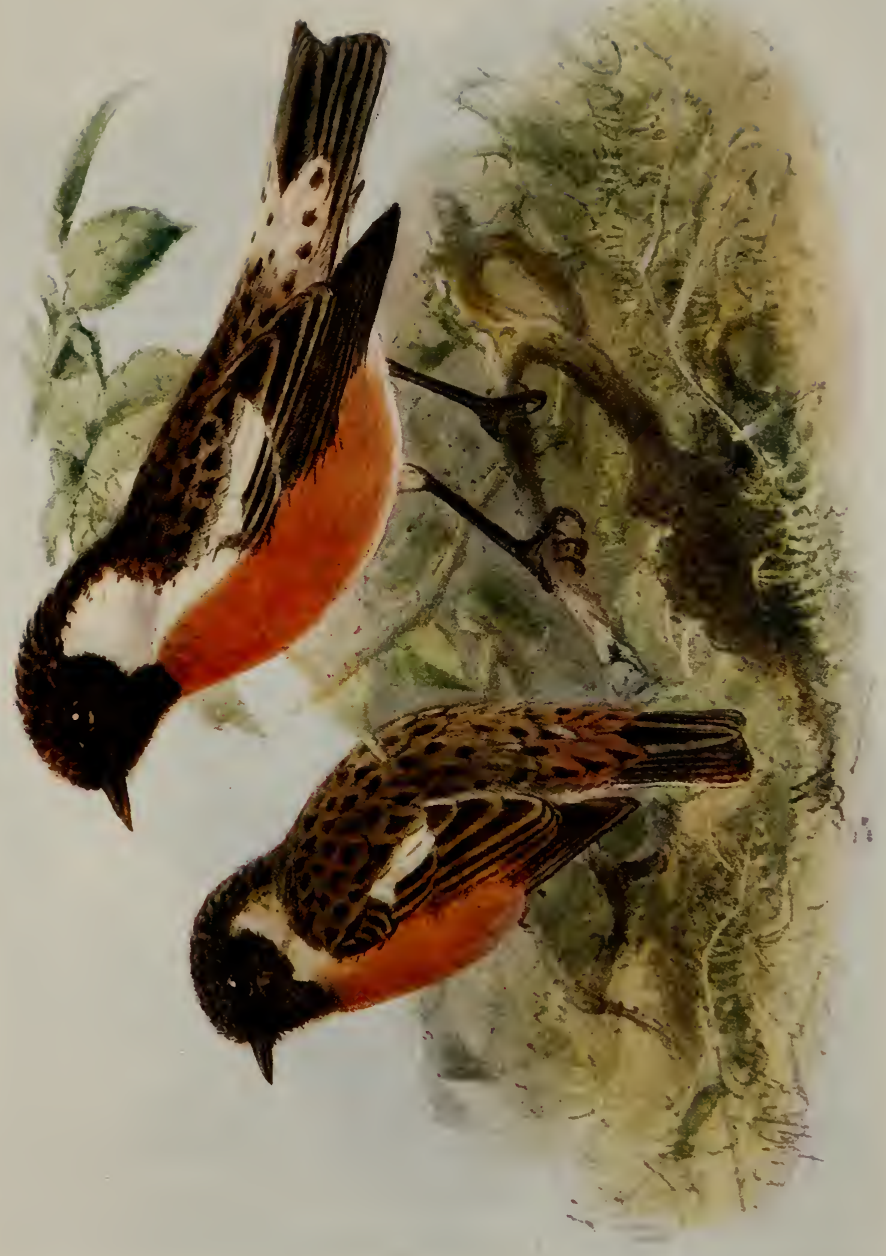





\section{The Stonechat}

brown with a conspicuous white patch on the wing coverts; breast and under parts bright rufous, lighter on the abdomen. The female has the upper parts striped with brown and the throat spotted with black. The white patches are smaller. The young are mottled and spotted with brown all over. Length 5 in.; wing 2.55 in.

\section{THE SIBERIAN STONECHAT}

\section{Pratincola maura, Pallas}

This is the representative of the preceding species in Northern Europe and Asia. One example only has been shot on our shores, viz. a male, in Norfolk, on September 2, 1904.

It is characterised by the pure white rump, but in other respects closely resembles the Common Stonechat.

\section{THE REDSTART}

\section{Ruticilla phœnicurus (Linnæus)}

Coming with the rush of our spring warblers, the Redstart, by its bright plumage, soon makes his arrival manifest. No one can mistake him, as with black head, white forehead, and red breast he sits on some tree in the garden, or on one of the pollard willows that fringe the stream, his tail vibrating with that curious sideway motion peculiar to his kind. It is in these early April days that he is seen to best advantage, staying in favoured spots till the advent 


\section{Birds of Britain}

of others of his tribe, a few days later, causes him to select both mate and nesting-site, after which he drives to "fresh fields and pastures new" those of his kind who seem inclined to throw too amorous glances on his chosen mate. A hole in a tree on the outskirts of a wood, along a river, or in a park, is the selected spot for their residence. The nest is loosely constructed of moss lined with hair, and in it are laid five to six eggs of a delicate blue colour much resembling those of the Hedge Sparrow. The hen is a much duller coloured bird than the cock, but with a red tail, which she moves with the same characteristic motion; she undertakes alone the duties of incubation, her lord and master keeping her well fed with insects, flies, and any living creature of suitable size that he is able to capture. In the intervals of catering for her or while listlessly waiting for "a bite," he will trill out his little song, which is, however, very feeble in quality as in quantity, for it consists merely of a disconnected ramble through a few short strains that are repeated again and again.

The male has the crown, nape, and mantle dark slate grey, rump and tail feathers (except the two centre ones, which are brown) chestnut. Forehead white; chin, throat, and cheeks black. Under parts, including the axillaries and under wing coverts, chestnut. The female is brown on the whole of the upper parts except the rump and tail, which are chestnut as in the male but duller. Under parts dull rufous. The young in their first plumage are spotted above and below. In winter both sexes have broad dull margins to their feathers, which conceal, to a great extent, the bright colours of the male. Length $5 \cdot 4 \mathrm{in}$; wing $3 \cdot 1 \mathrm{in}$. 



\section{REDSTART}

Ruticilla phonicura

Male (right). Female (left) 


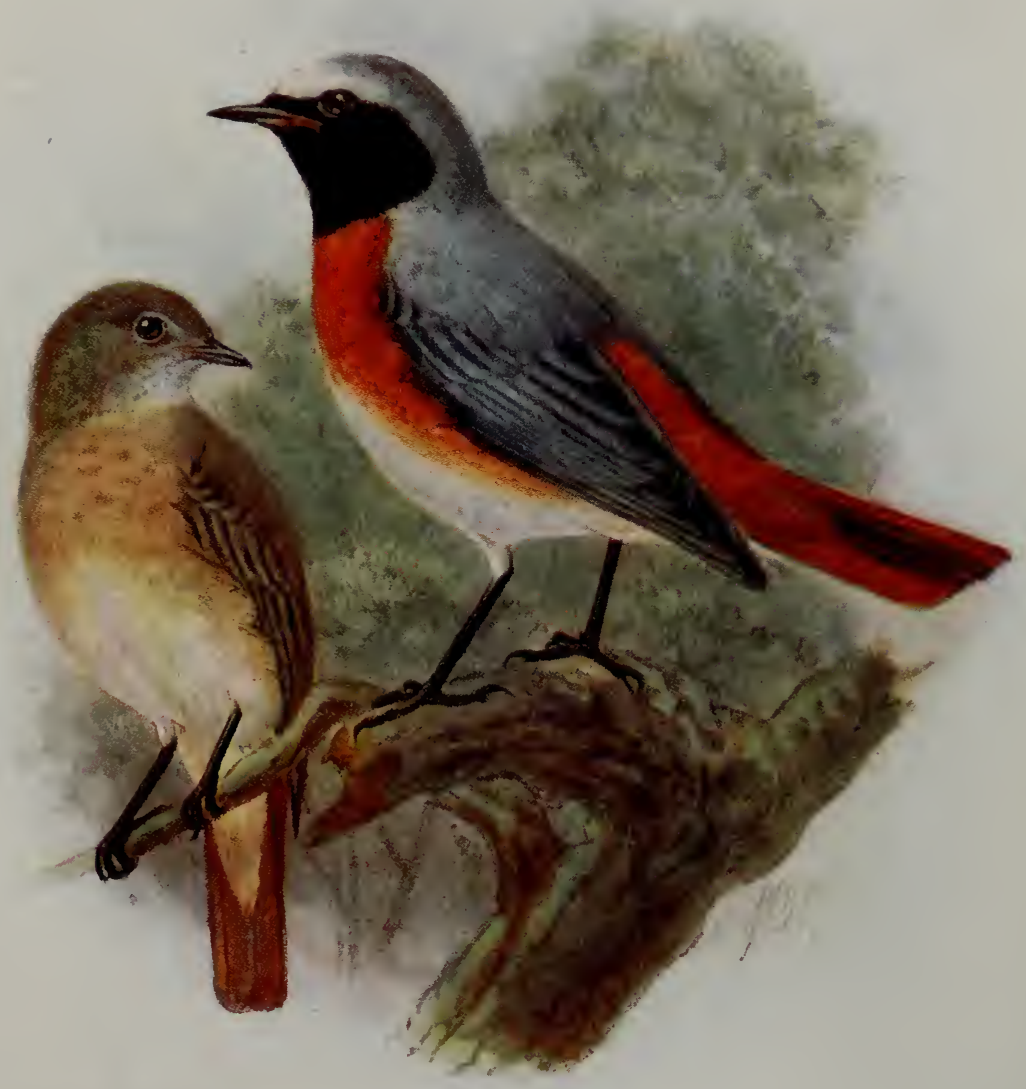





\section{The Redstart}

This species is fairly common in England except in the south-west, where it becomes very rare. In Scotland it is local but widely distributed. In Ireland, however, it is only known to breed in one or two counties.

\section{THE BLACK REDSTART}

\section{Ruticilla titys (Scopoli)}

The Black Redstart occurs with us as a regular autumn migrant but only in small numbers, frequently remaining till well on in winter. On the Continent south of $52^{\circ}$ it is an extremely abundant summer visitor, becoming more numerous in the east. In the southern limits of its range and in North Africa it is resident, though its numbers become augmented each season by individuals that have bred farther north.

The male is extremely dark in appearance and may be easily recognised from the Common Redstart by its uniformly black breast, the white outer margins to the secondaries, and black under wing coverts. The hen is much darker than our bird, especially on the back, which is of a uniform umber brown, but the unfailing characteristic of this species in all plumages and at all seasons is the dark brown or blackish under wing coverts. Length $5 \cdot 75$ in.; wing 3.4 in. 


\section{Birds of Britain}

\section{THE BLUETHROAT}

\section{Cyanecula suecica (Linnæus)}

There are two forms of this species, one in which the blue throat exhibits a red spot, and the other in which the blue throat exhibits a white spot. The former form is found breeding in Northern Europe and Siberia, wintering chiefly in South Asia and North-Eastern Africa; while the latter breeds in Central Europe south of the Baltic. The females and young of the two forms are practically indistinguishable. It seems probable that a few examples of this species occur annually on migration along our eastern coasts, but much more numerously in some years than in others. These visitors are for the most part immature, and until recently all the adult males that had been taken belonged to the northern or red-spotted form. During the last five years, however, two examples of the white-spotted form have been obtained on the Sussex coast. There is a variety of the white-spotted form in which the throat is unspotted, but it has not yet been satisfactorily identified in this country.

When on migration they will generally be found skulking in hedges and undergrowth near the coast.

The male has the upper parts of a warm brown. There is a white stripe passing through the eye; the upper tail coverts and bases of the tail feathers bright bay, rest of tail dark brown. Chin, throat, and gorget brilliant ultramarine blue, succeeded by bands of black, white, and bay; rest of 


\section{The Bluethroat}

under parts whitish. In the female the whole of the under parts are whitish with a brownish band across the chest. The young in first plumage is not unlike a young Redbreast, but has bases of the tail feathers bay. Length 5.3 in.; wing 2.85 in.

The name suecica refers strictly to the red-spotted form, the white-spotted form having been named wolf by C. L. Brehm in 1822 .

\section{THE ROBIN}

\section{Erithacus rubecula (Linnæus)}

Of all our British birds, none perhaps has gained so complete a hold upon our imaginations, and the more sympathetic side of our nature, than our red-breasted friend. $\mathrm{He}$ is a welcome guest in every home in the kingdom, and in turn acknowledges the compliment by trusting us as do few of our native birds. It is in winter perhaps that we know him best; however cold and stormy the weather, he always appears happy, cheerful, and sprightly, as he hops along the garden path or seeks his breakfast at the diningroom window, returning thanks by a brilliant but short outburst of song from some neighbouring bush or wall.

He has only one fault, and that is extreme pugnacityother birds (not excluding that great bully the Sparrow) live in awe of him and keep a respectful distance, but it is a different matter with those of his own kind who are always "spoiling for a fight." As soon as one has found a good point of vantage, or, if he be not too hungry, some 


\section{Birds of Britain}

dainty morsel, he will call out with a peculiar shrill single syllabled "tzsee," as much as to say, "I have found something good and dare you to take it." This challenge is almost sure to be taken up and swiftly repeated, not once but many times. The challenged one will slowly approach, there will be a short sharp fight, not much damage apparently being done to either combatant, and away will go the vanquished, while the victor, having eaten the "bone of dissension," fluffs out his feathers, reels off a few bars of his song, and then flies off to repeat the performance elsewhere. So the winter passes, till gradually, as spring comes round, and with it other birds, we are apt to forget our little winter friend, his memory being only kept alive by occasional glimpses of a red breast in the thicket or on the ivy covering the wall. The Robin who cheered us in the cold winter days, though we are perhaps unaware of the fact, has really gone, being engaged in bringing up his brood in some other part of the country, and his place has been taken by another from the south. There was probably a short interregnum, but we did not notice it, imagining probably that more abundant food had caused him to refuse the modest pittance of bread-crumbs that we were accustomed to put out daily for his especial benefit. The new-comer is certainly rather a shyer bird, at least we see less of him, but he is too busy to hang round the house; when he first comes he has to make sure of his footing, any rivals within call have to be disposed of, not in the halfhearted happy-go-lucky way that was good enough during the winter, but effectually disposed of once and for all. His next care is the choosing of a comfortable site for his 

ROBIN

Erithacus rubecula

Adult (right). Young (left) 


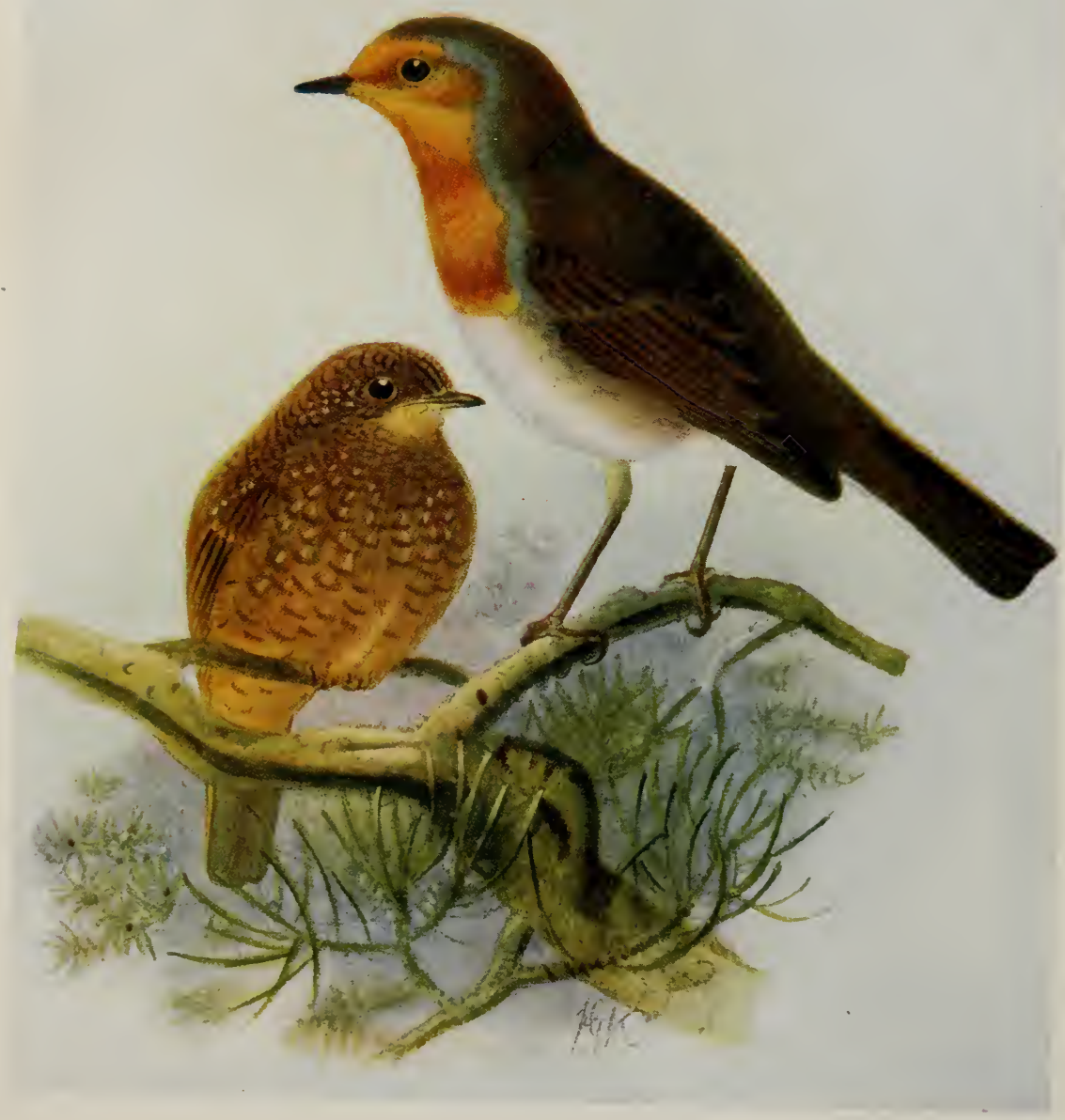





\section{The Robin}

nest; this is generally in some hole in a bank or wall, at no great height from the ground, and concealed with considerable care. The nest itself is chiefly composed of moss, with a lining of horsehair carefully felted together. The Robin is an early breeder, the nest being often completed by the end of February or early in March, but the eggs, usually six in number and of a pale reddish-buff colour, sometimes nearly white with red spots, are not, as a rule, laid till quite the end of March or beginning of April. As is customary in this family the incubation is carried on by the hen alone, while he roams about the vicinity, feeding her as opportunity offers, or sitting on some twig trilling forth his song. After the young are hatched he has but little time for singing, and has to work with a will to keep the six hungry youngsters satisfied, the hen also assisting him. When they leave the nest the young are clad in a uniformly mottled greyish-green plumage, which, however, is soon moulted, and they then become like their parents.

The first brood off their hands, the parents busy themselves with a second, and sometimes even with a third, and then towards the end of July they become restless, and both old and young are seen no more in their summer haunts. We shall not have long to wait however,- - probably some casual wanderers will frequently be seen, here to-day and gone to-morrow, wandering about in an irresponsive manner as the spirit moves them-but as the leaves fall and the days shorten, these wanderings will cease, and we shall find a cheery robin at our windows day after day, a bright spot of vigorous life in the midst of the sleeping 


\section{Birds of Britain}

vegetation, till we lose him again in the following spring amid the bustle and rush of reawakening life.

The sexes are practically alike and have the upper parts olive brown; frontal band, lore, chin, throat, and upper breast reddish orange, bordered on the throat and breast with bluish grey; flanks brown; rest of under parts white. Length $5 \cdot 75$ in.; wing 3 in.

\section{THE NIGHTINGALE}

\section{Daulias Iuscinia (Linnæus)}

The name of this bird is familiar to every one-ornithologist or otherwise. Poets have sung his praises for centuries, and not in vain, for there are few who do not in consequence feel a desire to hear this unsurpassed musician of the bird world. Like all good things, however, our songster does not overwhelm us with his melody. On his arrival in this country, about the third week in April, he bursts forth, pouring out his ecstasy in glorious and varied song. What a thrill it gives us as we listen on a warm spring evening to the liquid notes bubbling forth and resounding through the still air. He pauses for breath, and we can then hear in the distance the voice of another and yet another answering the song, the more distant warbling sounding as echoes of our own musician, till the whole country-side is full of exquisite melody. We retire, feeling in ourselves the magic of that "breath of spring" which has brought the ever-welcome wanderer to our shores once more. To attempt to describe that song in words 




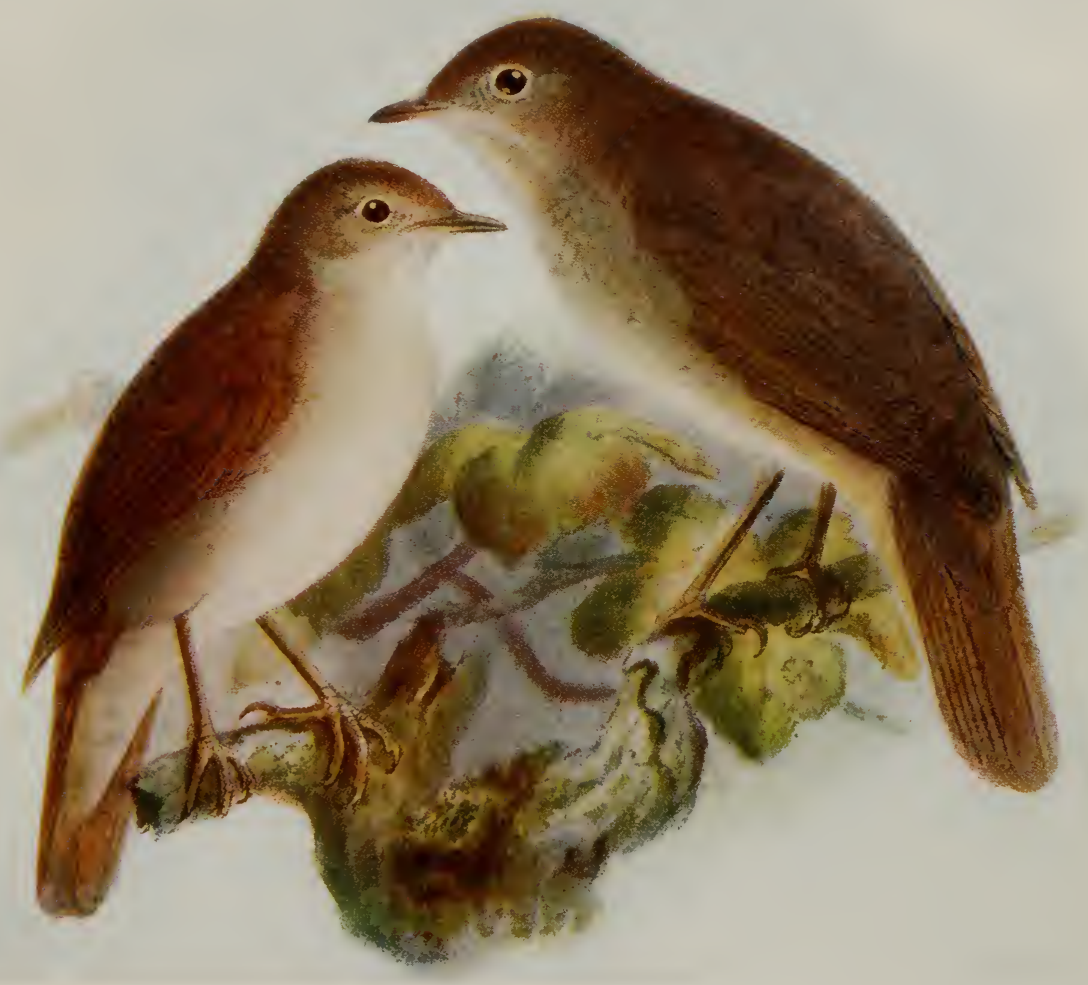





\section{The Nightingale}

would be impossible; loud and clear with full-toned deep liquid notes, now rising with impassioned fervour, and then, suddenly stopping, he recommences after a telling pause with a low plaintive cry. There is no mistaking it when heard; it is the trained voice breathing soul and fire with every note, compared with which the songs of our other birds, however bright and joyous, are like dismal pipings.

Soon after his arrival comes his mate, and then the song will be at its best and continue both day and night, till one wonders how and when he can sleep. Nest-building is begun almost immediately; a site is chosen on the ground in some thicket, and a delicate cup is formed of dead leaves loosely laid together with a lining of horse hair and other finer materials. The eggs are of a uniform dark olive green and are generally six in number. The hen alone sits, and when disturbed hops away silently from her nest, rendering it very difficult to be discovered. Small woods and coppices are the situations most popular with these birds, especially narrow strips of woodland bordering fields, to which they often make excursions in search of their food. This consists entirely of insects; spiders and flies forming the greater bulk, though no insect comes amiss. These are almost entirely sought for on the ground, and in fact he very seldom seeks the upper branches of the trees or bushes, preferring to remain hidden in their lower recesses.

As soon as the young are hatched the song ceases, and a harsh croak is the only sound emitted as he watches us passing near his nest. One brood only is reared, and then they seem to disappear from our "ken." Shy and silent birds, always keeping to the thick cover, they spend a few 


\section{Birds of Britain}

weeks quietly, feeding on the abundance of insects provided at this time of year, and then when the moult is over and they are strengthened for their journey, they leave us for their sunny winter home in Africa, while we remain behind to cherish, amidst gales and rain, the memories of those glad spring nights.

The plumage above is warm brown, passing to reddish brown on the tail and tail coverts; under parts greyish white, buffish on the flanks and breast. The young have light centres to the feathers of the upper parts and are indistinctly barred on the breast. Length $6.5 \mathrm{in}$; wing 3.35 in.

In our islands this species has a very restricted range, being only known to the south-east of a line from the Humber to the Severn. In Shropshire and South Wales it is sometimes heard, and the same may be said of Devonshire, where, however, of late years a pair or two have nested annually.

(This species sometimes exceeds in size the Greater Nightingale or "Sprosser," which has been recorded from this country, but our bird may always be recognised by the larger bastard primary, which in the "Sprosser" is minute.)

\section{THE WHITETHROAT}

Sylvia cinerea, Bechstein

Quiet and unobtrusive in his colouring, and like all his class retiring in his habits, this extremely common summer visitor is often hardly noticed. Early in April the White- 




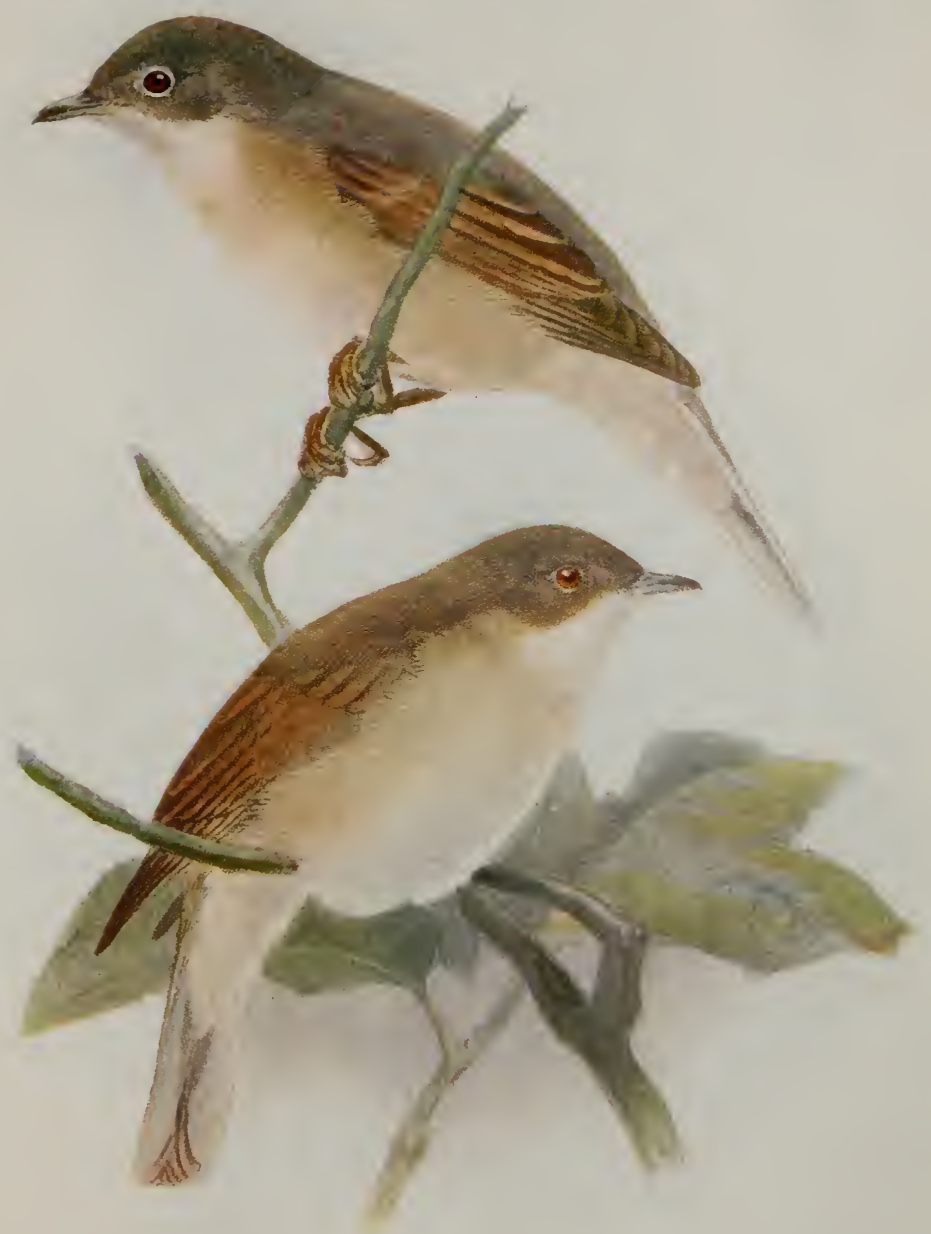





\section{The Whitethroat}

throats begin to arrive, and from then to the end of the month populate our hedgerows in ever-increasing numbers. When he first comes he may be seen sitting on some outstanding twig or on the telegraph wires that border the road, trilling forth his short but pleasing song, which, like that of most warblers, is a mere medley of notes put together without any apparent order or meaning, though to our little brown friend himself it is doubtless pleasing, and it is indicative of the vigour and energy he feels with the prospect of the return of summer. Anon he will drop from his perch into the hedge, throwing up his tail as he does so, rather after the manner of a Blackbird, and will rapidly wend his way by means of short leaps from twig to twig, giving him apparently a creeping motion, whence his local name of "Nettle-creeper."

On the arrival of his mate a few days after himself, they set up housekeeping with little or no delay. The nest is a very delicate structure built low down in some bush, or in a clump of nettles on the outside of the hedge, it is composed of grass and bents lightly but strongly interwoven and lined with a few horsehairs, and though looking very fragile and thin, it serves its purpose well. The eggs, four to six in number, are of a yellowish-olive colour blotched and spotted, especially near the larger end, with purplish blue. The hen alone sits, while her mate warbles his song to relieve her tedium, or searches for insects and flies, which he continually brings her. The young are hatched in about eleven days, and in another fortnight are hopping about accompanied by their parents, who still tend them for a short time, till the cares of another family engross their 


\section{Birds of Britain}

attention. For the rest of the summer these birds may be found in small parties in woods, fields, furze, commons, or hedgerows, wherever cover is to be obtained, feeding on caterpillars, flies, and insects, of which there is an abundance at that time of year. In July and August they renew their worn plumage and become extremely fat, and then when the September equinox warns them that the best of the summer is past, they go southwards to the shores of the Mediterranean and to Africa, there to pass the winter till returning spring once more prompts them to risk the perils of the journey and to revisit their summer home.

The male has the head and neck dark grey, mantle and wings brown with broad rufous edges to the secondaries. Tail feathers brown, except the outer pair that are white and the next pair that are tipped with white. Under parts white, fading to pale vinous on the breast and flanks. The female is duller and has the head brown; the young are rather more tawny. Length 5.5 in.; wing 2.8 in.

This bird is common throughout the United Kingdom except the extreme North of Scotland.

\section{THE LESSER WHITETHROAT}

\section{Sylvia curruca (Linnæus)}

The Lesser Whitethroat arrives a little later than the preceding species, namely about the end of April, and at once disperses throughout our woods and coppices and sets to work nest-building. The nest is still more fragile than the Whitethroat's and lacks the lining of horsehair. It is 

LESTER WHITETHROA'T

Sylvia curruia 


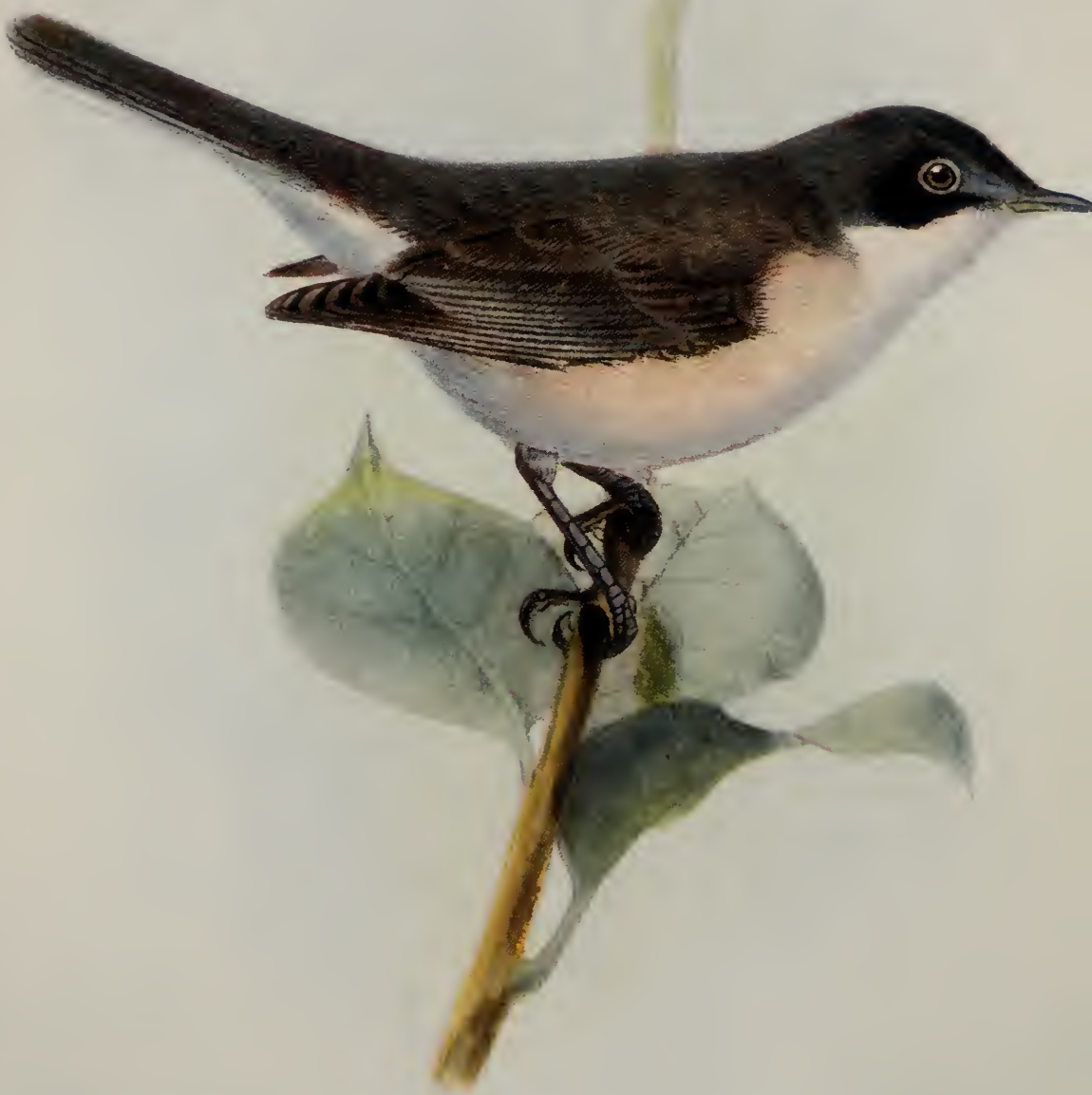





\section{The Lesser Whitethroat}

generally placed moderately high up, about four or six feet from the ground, in a bush or hedge bordering a coppice. The eggs, four to six, are of a light cream ground colour, with a zone of dark spots round the larger end. The hen sits very closely and does not leave her eggs unless almost touched; she does not then fly, but hops quietly away into the undergrowth, where she remains motionless till the danger, real or imaginary, has gone. The young when fledged resemble their parents, and two broods are as a rule reared. Its song is a monotonous "Sip, sip, sip," repeated again and again.

Although by no means scarce, it is seldom seen unless specially searched for, most of its time being spent quietly hopping about the undergrowth searching for food, which consists almost entirely of minute insects, small caterpillars, etc. etc. It is never seen in flocks, even when migrating, a few family parties in autumn being the most that are ever noticed together.

This bird has no distinctive plumage, and except for its note is very difficult to identify. The crown is smoke grey, cheeks and rest of the upper parts brownish grey, the outer feathers of the tail having white outer webs. Under parts whitish, becoming buff on the flanks. Bill black; legs slate colour. Length 5.25 in.; wing 2.6 in. The female and young are rather duller in colour.

In our southern, eastern, and midland counties it is a fairly abundant summer visitor ; in the West and North of England and South of Scotland it is decidedly rare, and over the rest of our islands it is a very irregular straggler and has only once occurred in Ireland. 


\section{Birds of Britain}

\section{THE ORPHÆN WARBLER}

\section{Sylvia orphea, Temminck}

This species nests abundantly in Spain and more sparingly in the South of France, but has been taken in this country on at least two occasions, on both of which the evidence pointed to its breeding or having bred with us. The eggs, except in size, are much like those of the Lesser Whitethroat.

The bird itself much resembles a Blackcap, but the throat and breast are white and the three outer pairs of tail feathers show some white. The female is rather duller and browner. Length 6 in.; wing $3 \cdot 1$ in.

\section{THE SARDINIAN WARBLER}

\section{Sylvia melanocephala, Gmelin}

This small species, which is not unlike the Blackcap in general appearance, has a comparatively restricted distribution, being practically confined to the Mediterranean basin. The only British specimen that has hitherto been obtained was shot on June 3,1907, in Sussex.

General colour of upper parts dark grey, except the head, which is black. Lower parts white, greyish on the flanks. Length 5.5 in.; wing 2.5 in. 


\section{The Blackcap}

\section{THE BLACKCAP}

\section{Sylvia atricapilla (Linnæus)}

Those whose good fortune does not allow them to live within earshot of the Nightingale, point to the Blackcap as having a song little, if at all, inferior to that of the prince of songsters.

Comparisons are at all times odious and in this case misleading, for to our mind no comparison can possibly be made between the two; the song is not only different, but lacks also the passion and tone so characteristic of the Nightingale.

Although a few Blackcaps sometimes winter in Devon, they are really migrants, and we gladly welcome this little bird when he makes his appearance in the spring. He will not often be seen, for, like all his tribe, he delights in woods and coppices, keeping low down in their leafy shade, and hopping along quietly from branch to branch as we approach.

His nest is very slight, made of dry grass lightly woven together and lined with a little horsehair. The eggs are very variable, being usually of a dirty creamish colour, blotched and spotted with darker brown, or sometimes of a reddish tint with dark red spots. Their food consists almost entirely of insects, and it is on this diet that the young are reared, but as the berries and fruit ripen in the hedges or our gardens a large toll is taken, especially of currants and raspberries, of which they are extremely fond. Like the nightingale their song ceases with the hatching of 


\section{Birds of Britain}

the young, and for the rest of the year they are almost silent except for a harsh scolding note if the nest or young are approached. Towards the end of summer it leaves us, but for some time previous to its departure it has been so quiet and skulking that its actual departure will probably be quite unnoticed.

The adult male has the head black and the rest of the upper parts ash brown. Chin greyish white; throat, breast, and flanks ash grey; belly white. Bill horn colour. Legs lead colour. The female has the top of the head reddish brown and the young at first resemble her. The males, however, assume their black head in their first autumn, but occasionally the cap shows a decided tinge of rufous. Length 5.75 in.; wing 2.75 in.

This species is fairly common in England and Wales but rarer and more local in Scotland and Ireland.

\section{THE GARDEN WARBLER}

\section{Sylvia hortensis, Bechstein}

In our minds this bird, for some reason which is not very clear, is always associated with the Blackcap. They are almost identical in habits and live in similar situations, but at the same time, although both species may often be found breeding together, the one is generally common in localities where the other is scarce and vice versa.

It is rather a late arrival, rarely appearing in numbers before the end of April, and has never been known to winter in these islands. 

BLACKCAP

Sylvia atricapilla

Female (above). Male (below) 


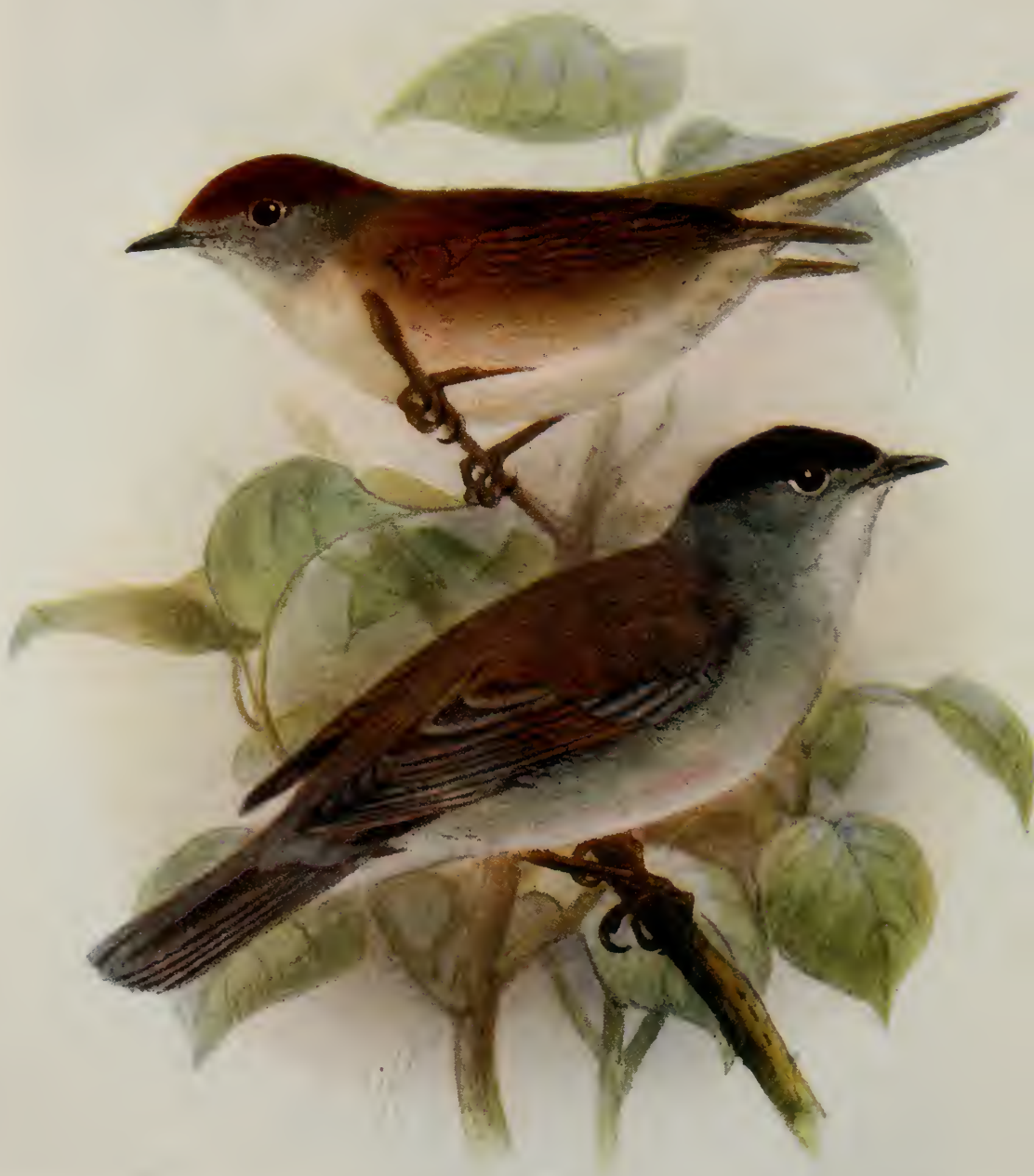





\section{The Garden Warbler}

The nest also resembles that of the Blackcap in structure, and though the present species never lays the reddish type of ego common to the Blackcap, its eggs are very similar to the creamy variety of the latter, but the markings are as a rule more blotchy and the clear-cut small spots are far fewer.

"Garden" Warbler is to some extent a misnomer, as it is seldom found in gardens, preferring woods and coppices in the open country, and not visiting the currant bushes anything like so frequently as the Blackcap.

The sexes are alike and are of a uniform olive brown, rather darker on the wings and tail. Under parts buffish white. There is a pale streak over the eye and a greyish area on the lores.

The young are almost indistinguishable from their parents. Length 5.75 in.; wing 3 in.

Except that it is scarcer and more local, its distribution in our islands is similar to that of the Blackcap.

\section{THE BARRED WARBLER}

\section{Sylvia nisoria, Bechstein}

Making its summer home in South Sweden, Denmark, East Germany and Central Europe, our islands lie too far to the west for this species to be known except as a rare straggler. About a dozen examples are known to have occurred in our eastern counties, always in autumn; it has also been taken in Skye and on two occasions in Ireland. 


\section{Birds of Britain}

The general colour above is ash grey faintly barred with slate on the upper tail coverts. Under parts whitish barred with grey. The young bird is hardly barred at all and somewhat resembles a large Garden Warbler. Length 6.5 in. ; wing $3.4 \mathrm{in.}$

\section{THE SUB-ALPINE WARBLER}

\section{Sylvia subalpina, Bonelli}

Breeding numerously in Spain and South-East France, this species has only once occurred here, namely on St. Kilda in June 1894.

The upper parts are dull grey and under parts chestnut. There is a red ring round the eye and a conspicuous white moustache-like streak extending backwards from the bill. The female is much duller and the under parts are pale buff. Length $4 \cdot 7$ in.; wing $2 \cdot 3$ in.

\section{THE DARTFORD WARBLER}

\section{Sylvia undata (Boddært)}

This bird, which is extremely rare and local with us, is the only resident member of its genus in these islands. Braving as it does our changeable and stormy climate, it is perhaps not surprising that its numbers are few, for, feeding almost entirely on insects, it must at times suffer severely from lack of food. Local, perhaps, is hardly a strong enough word to express the very stay-at-home habits of this cheery 
1)ARTFORI) WARBIER

Svivia undata

Male (above). Young (below) 



\section{The Dartford Warbler}

little fellow; he seems to have gone to the opposite extreme, and, while his congeners cross large stretches of the earth twice a year, he remains at home practically on the same bush. In habits he is very skulking, hiding in thick furze bushes. He will, when disturbed, take a short flight and then dive down into the thickest part of another shelter, and all we can notice in the short glimpse we get of him, is that he is extremely dark. The common on which he lives, may be many miles in extent, and apparently uniformly covered with furze and rank grass, and yet he will only be found in a special batch of furze perhaps not a hundred yards in length ; there, summer and winter, we may always find a small colony, while on the rest of the common we shall hardly ever see a single individual. In spring he becomes bolder, and we may watch him as he sits on the topmost spray of a bush, flirting his tail and throwing his body and wings into many and varied positions while he rattles forth the hurried medley of notes which serves him for a song.

The nest, which is placed low down in a furze bush and well concealed, is formed of bents and furze loosely woven together and is lined with horsehair, wool, or finer grass according to the materials at hand. The eggs are whitish, very closely speckled with reddish brown, and two broods are frequently raised in the season. The sexes are alike, and have the upper parts dark slate grey. Tail long and fan-shaped, the two outer pairs of feathers having white margins and tips. Under parts chestnut streaked with white in autumn. Length $5 \cdot 1$ in.; wing $2 \cdot 2$ in.

It is found only in the South of England and sparingly in Norfolk, Suffolk, and the Midlands. 


\section{Birds of Britain}

\section{THE GOLDEN-CRESTED WREN}

\section{Regulus cristatus, 'K. L. Koch}

The Goldcrest is the smallest of all our birds, and though not often seen it is extremely abundant wherever a fir or cone-fir plantation is to be found. Here it spends its life hopping about restlessly in search of the small flies and insects on which it exists. It has hardly any song, and the call-note is a very feeble high-pitched squeak, which often may be heard when the bird itself is invisible. The nest is, perhaps, the neatest and most beautiful structure of any to be seen in our islands, the Long-tailed Tit's not excepted; it is deep and cup-shaped, the outside being as well finished as the interior. The bough of a non-deciduous tree is almost invariably chosen, and from the end of the bough the nest is suspended, being firmly secured to the small lateral twigs. It is composed of moss, leaves, and fir needles woven with the aid of wool and cobwebs into a compact felted mass, the interior being lined with wool and a profusion of feathers. Six to ten eggs form the clutch ; they are creamy white, minutely and profusely dotted with reddish brown.

In autumn this species wanders about in small parties, while large numbers frequently arrive on our eastern shores from the Continent in October.

General colour above yellowish olive green. Forehead whitish, bordered on either side by a blackish streak. Crown of the head and crest bright lemon yellow, becoming deep reddish orange behind. Wings brown with white tips to the 



\section{FIRE-CRISTED WREN}

Kesulus iguicapillus

(above)

\section{(GOLDEN-CRESTED WREN}

kegulus iristutus

(below) 


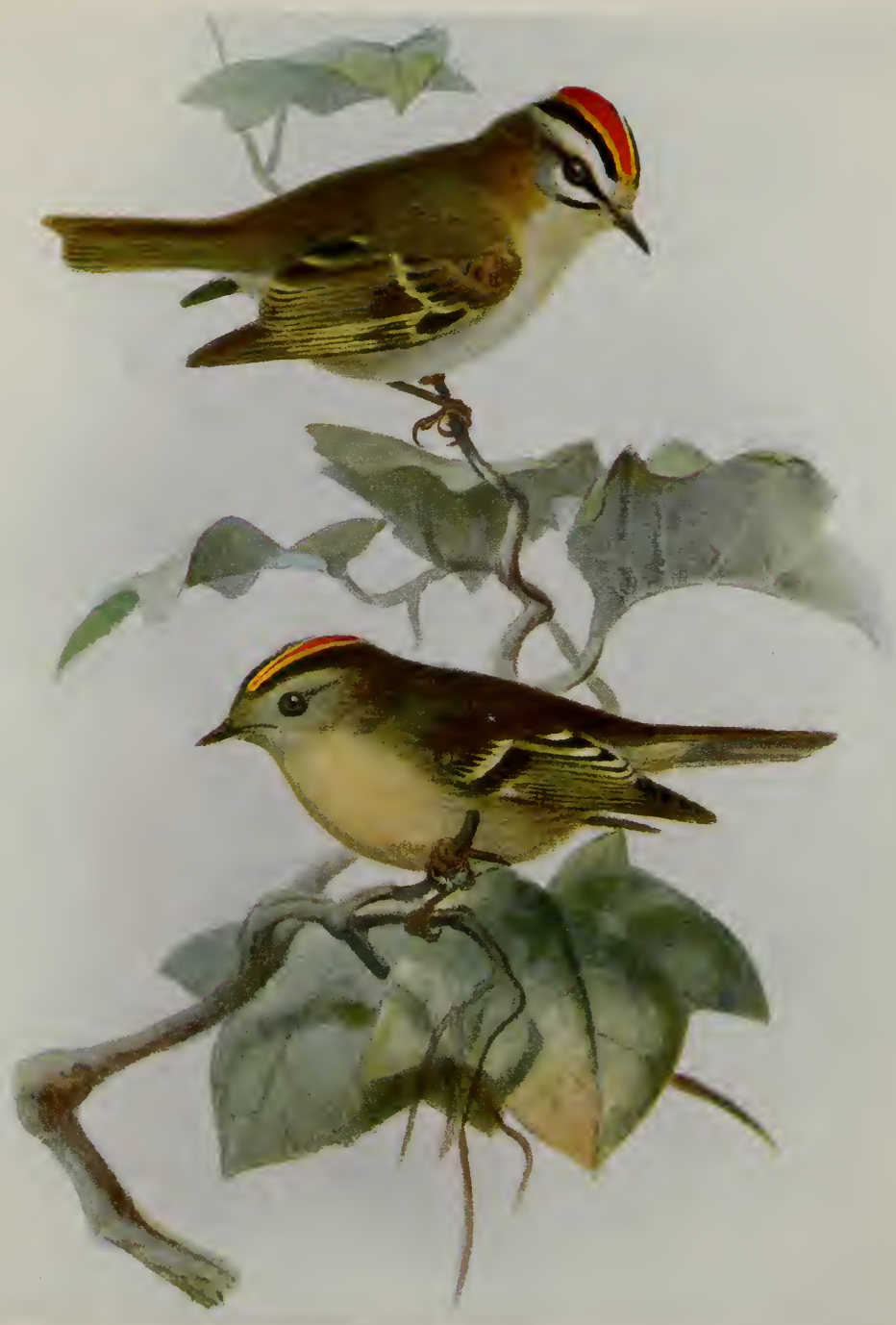





\section{The Golden-crested Wren}

secondaries and a black bar across the upper part. Median and greater wing coverts with white margins. Under parts greenish buff. The female lacks the bright orange in the crest and the young bird has no crest. Length 3.6 in.; wing $2 \cdot 1$ in.

\section{THE FIRECREST}

\section{Regulus ignicapillus (C. L. Brehm)}

This species is a rare wanderer to our southern counties during the winter months, although doubtless from its extreme similarity to the Goldcrest it may have been overlooked on several occasions. It nests throughout Southern and Central Europe, migrating southwards from its more northerly quarters on the approach of winter.

In appearance it hardly differs from the Goldcrest, but may be distinguished at all ages by a yellow frontal streak that passes backwards over the eye, succeeded by a black line through the eye, while another black streak runs backwards from the nape. Length $3 \cdot 7$ in.; wing $2 \cdot 1$ in.

\section{THE YELLOW-BROWED WARBLER}

\section{Phylloscopus superciliosus (J. F. Gmelin)}

This is an Asiatic species breeding in North-Eastern Siberia and wintering in South China, Burma, and North-Eastern India. It has been obtained on several occasions in these islands. 


\section{Birds of Britain}

The upper parts are olive green, under parts pale yellow. There is a faint yellowish stripe along the crown of the head and a very conspicuous yellow stripe, which passes over the eye, from the base of the bill to the nape. There are two bands of lemon yellow across the coverts, and the inner web of the outer tail feathers is margined with white. Length 3.8 in.; wing $2 \cdot 15$ in.

\section{PALLAS' WILLOW WARBLER}

\section{Phylloscopus proregulus (Pallas)}

A single example of this Asiatic species has been obtained in Great Britain, its true home being across Eastern Siberia, where it nests from Lake Baikal to the Himalayas and Northern China. It closely resembles the Yellow-browed Warbler, but its colours are brighter. The crown stripe is well marked. The inner web of the outer tail feathers is not margined with white, but its most distinctive feature is the bright lemon yellow rump. Length $3.7 \mathrm{in.}$; wing 2 in.

\section{THE GREENISH WILLOW WARBLER}

\section{Phylloscopus viridanus, Blyth}

In summer this species inhabits Western Siberia from the Urals to the Himalayas and has only occurred once in England. It is very similar to our Willow Warbler, but 


\section{The Chiffchaff}

the tips of the greater wing coverts are whitish and form a distinct bar. Length 4.25 in.; wing $2 \cdot 25$ in.

\section{THE CHIFFCHAFF}

\section{Phylloscopus collybita, Vieillot}

It has yearly been our delight to listen for the cheery "chiff chaff" which announces the first arrival of this bird. Winter is hardly over, the March winds still blow and the trees are bare, but still he comes to brave our inclement weather and retain his position as the first harbinger of spring. A small green Warbler of skulking habits, we will have to watch carefully if we wish to see him, for as we approach he will leave his post high up on some tree and hide in the undergrowth. For some weeks he wanders about the country, here to-day and gone to-morrow-apparently at the dictates of his own will, but in reality ever creeping up steadily northwards in the trail of departing winter. At the end of April or beginning of May, having chosen his mate, the duties of nest-building begin. The nest is loosely placed in some bramble thicket or undergrowth in a wood, and often appears as though it had been carelessly thrown there. It is dome or oval shaped, loosely built of bents, moss, and leaves, and warmly lined with feathers. The six eggs are white, dotted and spotted with dark reddish brown.

Its food consists almost entirely of small flies, caterpillars, and other insects, which it captures among the branches and leaves of the trees, rarely descending to the 


\section{Birds of Britain}

ground. Two broods are reared in the season and the rest of the summer is spent quietly and unobtrusively till, in October, the first storms of winter and growing scarcity of food compel it to retire southwards. This it does reluctantly, and a certain number spend the winter in the milder climate of Devon and Cornwall.

The upper parts are olive green ; wing coverts, quills, and tail feathers brown, edged with the same colour. Under parts whitish. There is a pale yellowish white streak above the eye. The sexes are alike in plumage and the young are slightly greener. Length 4.6 in.; wing 2.35 in.

This species may be distinguished from the Willow Wren by its smaller size and darker legs. The second quill is equal to the seventh and the outer webs are emarginated near their tips up to and including the sixth. In the Willow Wren the emargination only reaches the fifth and the second is equal in length to the sixth. It should be remembered that the first quill is very short and inconspicuous, so that the first apparent quill is the second.

This species is scarcer and more local than the Willow Wren. In Scotland it is local and is only a straggler to the north of that country and the surrounding islands.

\section{THE SIBERIAN CHIFFCHAFF}

\section{Phylloscopus tristis, Blyth}

One example of this small warbler, that breeds in Western Siberia, migrating to Turkestan and India in winter, was obtained at a lighthouse off the Orkneys in 



\section{CHIFFCHAFF \\ Phylloscupus collybita [Vieillot] \\ (above)}

WILLOW WREN

I'hylloscopus trochilus

(below) 


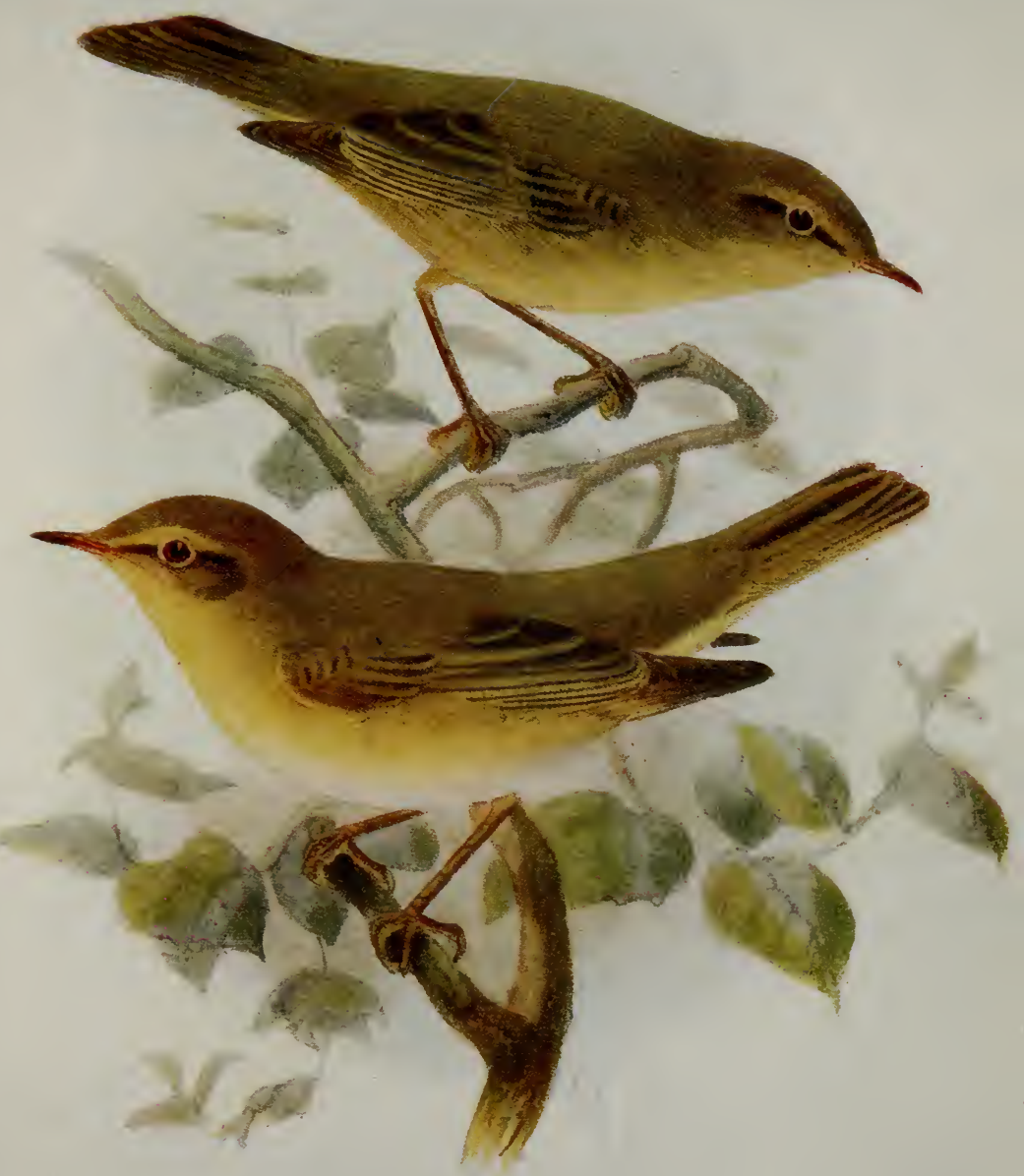





\section{The Siberian Chiffchaff}

1902. It is rather smaller and browner than our common Chiffchaff and has the under parts buffish white. It may, however, always be recognised by the shortness of the second primary, which comes between the seventh and the eighth, or is even shorter than the eighth.

\section{THE WILLOW WREN}

\section{Phylloscopus trochilus (Linnæus)}

The Willow Wren is closely allied to the Chiffchaff and so like it in general appearance as to need a critical examination, when dead, to enable it to be recognised. In habits also there is little difference to be noted. Its range is more extensive, for as far north as the birch woods extend, this hardy little wanderer makes his home, retiring at the end of summer to Southern Europe and Africa. Throughout our islands it is extremely common. Arriving about the last week of March, it at once makes its presence known by its bright little song, which is very short and somewhat resembles the Chaffinch's; it is repeated again and again, and may be heard right through the summer and sometimes again after the moult in the late autumn, just before their final departure.

The nest is similar in size, shape, and materials to that of the Chiffchaff, but differs in its position, being generally placed very near and often right on the ground, always well concealed in the undergrowth, whereas with the Chiffchaff it is always off the ground, sometimes 


\section{Birds of Britain}

only an inch or two, but more often some eighteen inches or two feet. The eggs are white with pale rufous spots; these markings are much paler than on those of the Chiffchaff, less clean cut, and more numerous.

Apart, however, from the breeding birds, an enormous number of Willow Wrens pass through this country at migration time. England seems to lie in the main track of these birds when they are making for their summer quarters in higher latitudes. From early April to the middle or end of May they simply pour through this country in incredible numbers. The whole extent of the south coast is involved, and often for several days at a time they arrive in millions. These birds pass straight on, relentlessly pursuing their course, and having crossed the Channel one night, prepare during the following day for a still longer journey across the North Sea during the coming night. Early in August the return journey commences, and in still greater numbers they steadily pass southwards, till by October they are, let us hope, enjoying peace and plenty under sunny skies.

Extremely like the Chiffchaff, but rather larger, brighter in colour, and with paler legs. Its distinctive characteristics have been noted under the preceding species. Length 4.9 in. ; wing $2 \cdot 7$ in.

\section{THE WOOD WREN}

\section{Phylloscopus sibilatrix (Bechstein)}

Although a member of the same family as the last two species, this bird is much more local. It is not until the 56 


\section{The Wood Wren}

end of April that he reaches our shores and his clear and melodious little song, which may be syllabled as "chit, chit, chit, chit, tri-tr-tr-tre," can be heard. His favourite haunts are suitable woods where large timber, especially beech, abound. Here he may be seen as, with the restless activity so characteristic of his family, he searches among the upper branches of the trees for those insects which, with berries of all kinds, form his staple food.

At the foot of some beech-tree, on the ground, or more rarely in some tangled thicket, the nest is built and well concealed by the use of materials similar to the surroundings among which it is placed. It is lined with grass and horsehair, but feathers, so freely used by the Chiffchaff and Willow Wren, are never found. The eggs are white, very thickly and uniformly mottled with dark red. After the young are hatched it becomes silent, and leaves us early in September.

The adult has the upper parts of a bright yellowish green, with a characteristic yellow streak above and behind the eye. The wings are brown edged with yellowish green. Throat and breast sulphur yellow, rest of under parts white. Bill and legs brown. Length 5.2 in.; wing 3.1 in. The larger size and brighter coloration are distinctive of this species.

It is a local bird, but may be found in suitable spots throughout the United Kingdom. In the north, however, it becomes rarer. 


\section{Birds of Britain}

\section{THE RUFOUS WARBLER}

Aedon galactodes (Temminck)

This handsome species is only a summer migrant to the South of Spain, and the few that have occurred in England are merely stragglers carried out of their course. It has been taken in Sussex and once in Devon, in all cases during the autumn.

It is a conspicuous bird, like a large pale-coloured Nightingale, and may be recognised by its fan-shaped tail with black subterminal spots and white tips. Length 6.5 in.; wing $3 \cdot 5$ in.

\section{RADDE'S BUSH WARBLER}

\section{Lusciniola schwarzi (Radde)}

This species, which breeds in North-Eastern Siberia and migrates in winter to China and Burma, has only once been obtained in this country, namely in October 1898, by $\mathrm{Mr}$. Haigh, on the Lincolnshire side of the Humber. Mr. Haigh's attention was drawn to it by the loud and powerful note. The general colour above is olive brown, tinged with tawny on the rump. Under parts yellowish white. There is a broad white superciliary stripe, which ends abruptly in a manner characteristic of this species. Length 5.5 in.; wing 2.45 in. 


\section{Cetti's Warbler}

\section{CETTI'S WARBLER}

\section{Cettia cettii, Marmora}

A single example of this species, whose home is in Southern Europe and the Mediterranean basin generally, was obtained in Sussex in May 1904.

The upper parts are chestnut brown, darker on the wings and tail. There is a white superciliary stripe. Under parts white, turning to grey on the breast, flanks, and under tail coverts. Length 5 in.; wing 2.3 in.

\section{THE ICTERINE WARBLER}

\section{Hypolais icterina (Vieillot)}

This fairly common European bird is only a rare visitor to our southern and eastern shores, and has once been taken in Ireland. It breeds in North-Eastern France, Denmark, Scandinavia, and throughout Northern and Central Europe, migrating south-eastwards in autumn, Italy forming apparently the western limit of its route. The eggs are very distinctive, being pale pink with black spots.

The upper parts are greyish olive, the lores and a streak over the eye yellow. Under parts lemon yellow. Length $5 \cdot 2$ in.; wing $3 \cdot 1$ in. 


\section{Birds of Britain}

\section{THE MELODIOUS WARBLER}

\section{Hypolais polyglotta (Vieillot)}

Although the presence of this species had long been suspected, as well as the possibility of it having bred with us, it was not until 1897 that the first authenticated example was procured at Burwash in Sussex. It is a southern species, breeding abundantly in Spain, North Africa, and South-Western France. Its eggs very closely resemble those of the Icterine Warbler.

Except for its smaller size, it is very difficult to distinguish this species from the preceding one, but its proportionately shorter wing, its larger bastard primary and the second primary being shorter than the fifth, form unfailing characteristics. Length $4.9 \mathrm{in}$; wing $2.5 \mathrm{in}$.

\section{REED WARBLER}

\section{Acrocephalus streperus (Vieillot)}

A near ally to the Sedge Warbler, this bird seldom reaches this country till the beginning of May, and at once repairs to the reed-beds, where his whole life, except when actually migrating, is spent. Wherever suitable reed-beds occur in the southern and eastern parts of our islands, he is fairly abundant and reveals his presence by his song, which is a harsh medley of notes volubly rattled out, and somewhat like that of the Sedge Warbler. It is easy to hear him, but to see him is a task requiring much patience and careful 

REED WARBLER

Acrocephalus streperus [Vieillot]

(above)

MARSH WARBLER

Acrocephalus falustris

(below) 


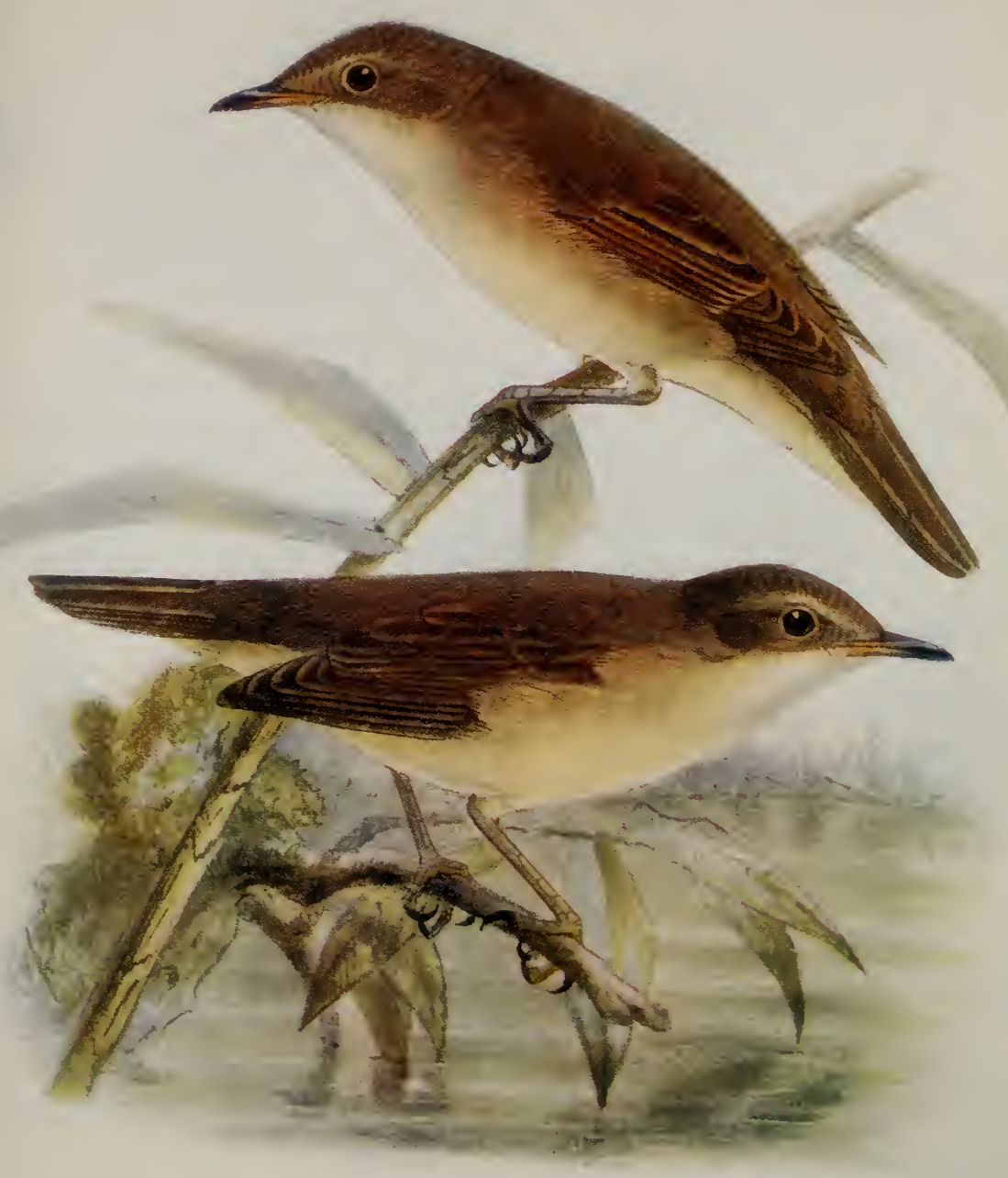





\section{Reed Warbler}

watching. He keeps entirely concealed by the reeds among which he lives, creeping along from one to another and assuming all kinds of strange attitudes. Now he hangs head downwards, or again, grasping a neighbouring reed with one foot, he will swing himself round and climb straddle-legged up two reeds, till on reaching the top he will perhaps take a short flight, only to dive in again a few feet farther on.

The nest is a most beautiful structure, carefully supported on four or five growing reeds which pass right through its walls and thus hold it secure. For the size of the bird it is extremely deep, a wise provision to prevent the eggs from being rolled out when the reeds are bent with the wind. The materials used are dry grass, bents, and moss, with a lining of finer materials. The eggs, four in number, are pale green, thickly freckled and mottled with a darker tone of the same colour.

When the young are hatched the inside of their mouths is of a deep red colour with two very conspicuous black spots towards the hinder end of the tongue; at this time the song of the parent ceases and we hear and see but little more of this species. With the autumn gales he leaves us for the marshes of Spain or the deadly swamps of Africa, where the small flies and insects on which he feeds may be found in abundance at all seasons.

The upper parts are of a uniform warm brown, slightly brighter on the rump, and there is a pale buff stripe over the eye. The under parts are white, the flanks and under tail coverts buffish. Length 5.25 in.; wing 2.5 in.

It is unknown in Scotland and Ireland. 


\section{Birds of Britain}

\section{THE MARSH WARBLER}

\section{Acrocephalus palustris (Bechstein)}

This species resembles the preceding one so closely that even when examined in the hand, they are hard to distinguish. The general hue is, however, more greenish and less rufous than the Reed Warbler, and the legs are lighter in colour, being brownish flesh instead of yellowish brown. Alike as they are in appearance, their life history is very different. The Marsh Warbler is by no means confined to reeds, but may be found in osier beds, cornfields or coppices, being content, like the Sedge Warbler, with a very small extent of water. It sings its song, which is much sweeter and more melodious than that of the Reed Warbler, from the topmost sprays of its home, and the nests are never suspended in reeds but placed low down in some osier or small bush. The eggs are pale greenish white, blotched and marked with dark green, and are so characteristic that they cannot well be mistaken for those of any other species. It has a wide range in Europe, becoming scarcer towards the west, but in this country it is very local, and restricted as a breeding species to a few places in the south.

Very difficult to distinguish from the Reed Warbler, but the general hue is much greener, and the difference in the colour of the legs has already been noticed. Length $5 \cdot 25$ in. ; wing $2 \cdot 7 \mathrm{in.}$ 


\section{The Great Reed Warbler}

\section{THE GREAT REED WARBLER}

Acrocephalus turdoides (Meyer)

Although common on the neighbouring shores of the Continent, this species has occurred here very seldom. It is abundant throughout Europe in summer as far north as the southern shores of the Baltic, and nests commonly in France, Holland, and Belgium. It inhabits reed-beds or thick cover near the margins of streams, ditches, and ponds. It does not skulk like the Reed Warbler, but, on the contrary, is always sitting on the top of the tallest reeds and flying about from one clump to another.

The upper parts are warm olive brown, with light margins to the wing and tail feathers. There is a dull whitish streak from the bill over each eye. The under parts are buff; chin and belly whitish. Length 7.8 in. ; wing 3.75 in.

It has been taken only in the South and East of England.

\section{SEDGE WARBLER}

\section{Acrocephalus phragmitis (Bechstein)}

The presence of a human being seems to spur this delicate species to song, for if, when strolling near some river or pond towards the end of April, we inadvertently pass this little songster, he will at once burst forth with his noisy chattering notes, as though loudly protesting against this unseemly invasion into his privacy. $\mathrm{He}$ is by no 


\section{Birds of Britain}

means shy, though he usually keeps to the low-growing alders, willows, or whatever other cover there may be, and should we come so close as to disturb him from his shelter, he merely flies on a few yards and recommences his song with redoubled energy. Although rather local in distribution, he is not rare, but is never found except near water, although that water may be only a horsepond surrounded with hawthorn bushes. About the beginning of May, having selected his mate and decided on a spot suitable for a home, family cares will be commenced, and the nest, placed within a foot or two of the ground and well concealed, will be begun. The nest is formed of grass and bents, loosely woven together and lined with finer materials and, occasionally, a few feathers. The eggs, four to six in number, are uniform pale clay brown, sometimes showing mottlings of a darker shade and having a dark hair streak towards the larger end. The young are fed on insects, which form also the chief diet of the parents, though berries are eaten in the season.

Two broods are often reared, and at the end of summer young and old pass away to the tropics. The sexes are alike in plumage, but the female is slightly duller. The upper parts are tawny brown, becoming brighter on the rump and upper tail coverts; the crown is broadly streaked with black, and edged on each side with a broad yellowishwhite superciliary stripe. Chin and throat white, breast and under parts buff. Length 5 in.; wing 2.5 in. The young are slightly spotted with brown on the throat.

Generally distributed throughout Great Britain, becoming rarer in the north. 


\section{The Aquatic Warbler}

\section{THE AQUATIC WARBLER}

\section{Acrocephalus aquaticus (J. F. Gmelin)}

The Aquatic Warbler is by no means scarce in Europe, but is one of those south-eastern species that extend northwestwards through France and breed sparingly in Holland and Denmark. From recent observations it seems probable that a few examples regularly pass through this country on migration every autumn, but owing to its resemblance to the Sedge Warbler, it has probably often been overlooked.

In general colour it is lighter and paler than the Sedge Warbler, and the wing coverts have broad buffish margins. Its characteristic feature, however, is the conspicuous buff stripe down the middle of the crown. Length $4.9 \mathrm{in}$.; wing $2 \cdot 4 \mathrm{in}$.

\section{THE GRASSHOPPER WARBLER}

\section{Locustella nævia (Boddært)}

Though never very abundant, this skulking species is commoner than is usually supposed. Arriving towards the end of April, its peculiar trilling song, which has earned it many local names, may often be heard. It sounds, however, so much like the noise made by a grasshopper that the bird is frequently unrecognised.

This species is rarely seen, for it loves to remain concealed in the thick undergrowth, either in a compact hedge or in large stretches of sedge and rough grass, but, if we trouble to trace 


\section{Birds of Britain}

it by its song, we may be lucky enough to see a dark bird moving near the ground with hesitating flight. As it drops after a very short journey into the cover again, we may have time to notice the rounded tail, which is always spread as it settles and is the best clue by which to identify this species on the wing. Approach the spot where he disappeared and you will search in vain, for he has already crept away, and in a few minutes the song will recommence several yards off.

As with all the Warblers, insects form their chief food. The nest, built of grass and bents loosely woven together, is placed low down and well concealed in the rough herbage near the ground, and as the bird seldom flies from it, but creeps silently away on our approach, it is exceedingly difficult to find.

Six eggs form the clutch; the ground colour is whitish, but they are very thickly and uniformly mottled and freckled with reddish brown. The general colour above is greenish brown, each feather having a darker centre. Wings and tail brown, the latter showing faint bars. Under parts brownish, slightly spotted on the throat and breast, darker on the flanks and paler on the belly. The sexes are alike in plumage. Length $5 \cdot 4 \mathrm{in}$; wing $2 \cdot 4 \mathrm{in}$.

\section{SAVI'S WARBLER}

\section{Locustella luscinioides (Savi)}

This species was once a regular migrant to certain favoured localities in the East Anglian fens, but subsequent 

GRASSHOPPER WARBLER

Locustella navia

Adult (above). Young (below) 




\section{Savi's Warbler}

drainage has so affected its haunts that it is no longer to be found there. The last known British specimen was killed over fifty years ago. Possibly a few individuals may sometimes occur on migration, as it still breeds locally in some parts of Holland, but, except for historical interest, it can no longer be included among our British birds.

The sexes are alike, and in size it slightly exceeds that of the preceding species. The upper parts are of a uniform reddish brown, under parts whitish, passing to buff on the breast and flanks. Length $5 \cdot 7$ in. ; wing 2.6 in.

\section{THE HEDGE ACCENTOR}

\section{Accentor modularis (Linnæus)}

Of dingy colour, quiet, unobtrusive, yet ever busy, the Hedge Accentor, vulgarly misnamed the "Hedge Sparrow," resembles in his character those among us who are content, even in the bustle of our great cities, to go quietly on their way, doing good wherever they find opportunity and receiving uncomplainingly the kicks which their busier brethren are often only too eager to bestow.

And so it is with the Hedge Sparrow; year in, year out, he is ever with us, quietly and diligently seeking his food along a hedge bottom, on the edge of a coppice, on the garden path, or wherever else he may happen to find himself. He does incalculable good in destroying numbers of noxious insects, and when winter comes, and such food is scarce, he turns his attention to seeds of all kinds, thus 


\section{Birds of Britain}

helping to keep down many weeds which would otherwise overrun our fields and gardens. Peaceful by nature, he has become very common, and imagining ill of none he is tame, hopping up from the path just in front of us, and disappearing quietly and without sound into the nearest cover, and then, working his way by quiet "creeping hops" (if such an expression be allowable) to the bottom of the bush or hedge, he reappears behind us. We in our turn, it is true, do not often molest him, in fact he is generally ignored and his presence unsuspected, and even when seen, many of us think- "only a sparrow!" and judge him and his acts by those of a race as different from him in habits and qualities as we are from the Chinese!

When he does utter a note, which is towards evening or when suddenly alarmed, it is a short shrill "iss," rather like a pencil being drawn across a slate; his song, which is commenced in March and only carried on during the breeding season, is like his own character, very sweet and unobtrusive, being in fact a low warble, wandering through its inconsecutive measures without any marked phrases or pauses. By early April he will have chosen his mate and the site for his future home, and now and again one may see him having a slight tiff with a neighbour, who may covet his particular nesting-place, but it is nothing serious, for the said neighbour, if defeated, will have his home but a few yards farther on and apparently enjoy possession unmolested.

The nest is a beautiful structure; the foundation is made of twigs and leaves, and the nest itself is of moss, strongly felted together and lined with horsehair; it is perfectly 

HEDGE ACCENTOR (HEDGE SPARROW)

Accentor modularis 


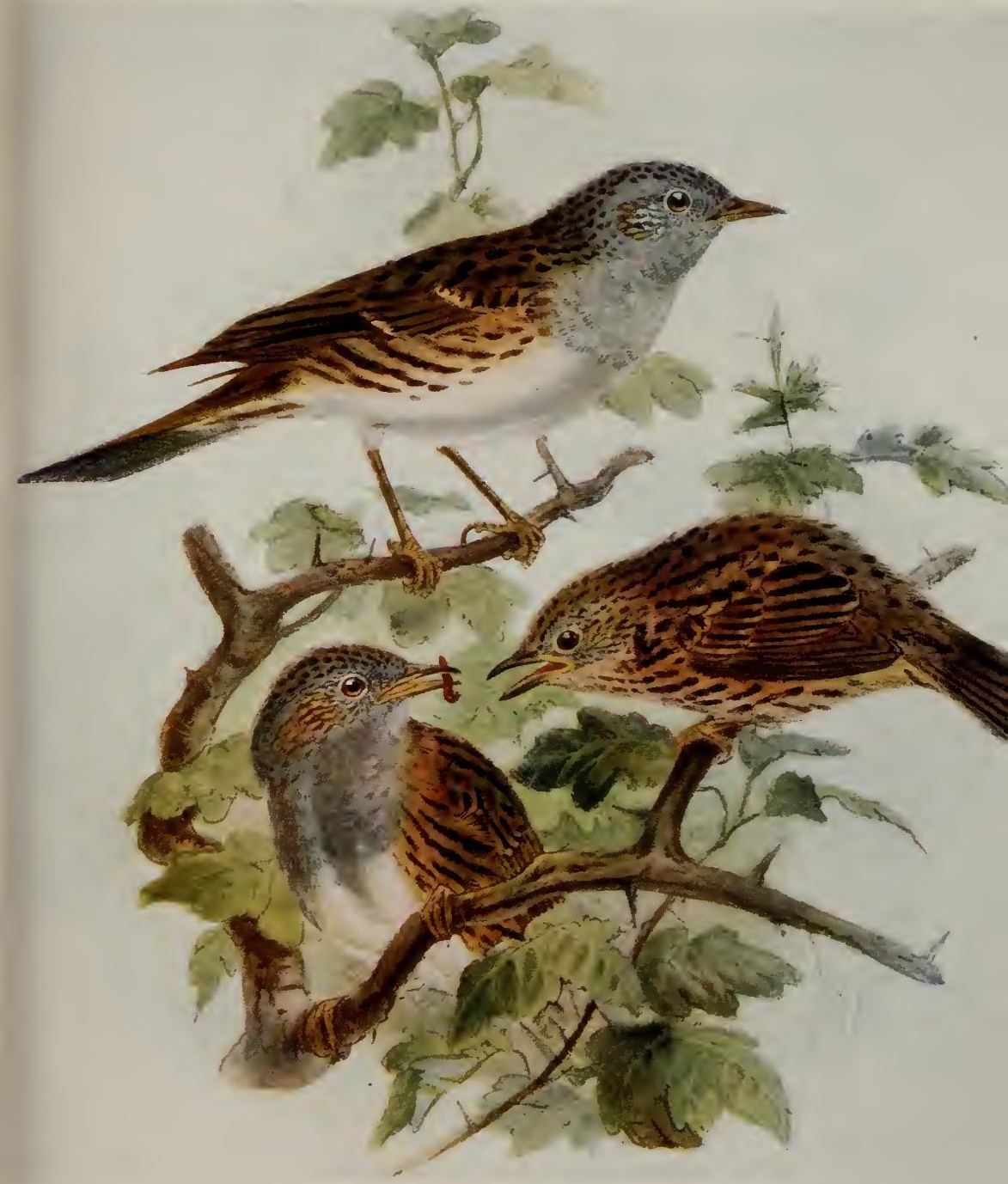





\section{The Hedge Accentor}

circular in shape and somewhat deep. Here are laid four eggs of a beautiful blue with no spots or blotches to mar the purity of the colour: altogether this little home is in its quiet way one of the most beautiful of our common natural objects; but_- it is only a sparrow," and the passer-by either destroys it or goes on without a thought for our little friend or the beauty of his home. When his mate begins her tedious business of incubation he attends to her wants with unremitting care, bringing her any delicacies in the shape of insects, flies, and caterpillars he can find. The young at first look like balls of down, and when they open bright orange-coloured mouths they are quickly filled with what is apparently a favourite food-luscious green caterpillars. When they leave the nest the young wear a dull mottled brown plumage, and without more ado take their place in the world around, and lead a quiet unobtrusive life near the home where they were bred, till their end comes by some natural means, or till their career for good is suddenly cut off and they are shot as being "only sparrows"!

The sexes are nearly alike, the head, nape, chin, throat, and upper breast are slate grey, rest of the upper parts rufous brown, with darker streaks; flanks brown streaked with darker, belly white. The female is slightly duller. The young are brown, spotted with buff all over. Length 5.5 in. ; wing 2.75 in.

This is a numerous species throughout our islands. 


\section{Birds of Britain}

\section{THE ALPINE ACCENTOR}

Accentor collaris (Scopoli)

The Alpine Accentor is an inhabitant of the mountainous regions of Central and Southern Europe, and, like our Hedge Accentor, of very stay-at-home habits, rarely leaving its home until the snow forces it down into the valleys. In England and Wales it has occurred about a dozen times.

In general colour above it is not unlike the preceding species, but the wing coverts are tipped with white, forming a double bar across the wing. Chin and throat white mottled with black, rest of under parts greyish brown, the flanks mottled with chestnut. Length 7 in.; wing $4 \cdot 1$ in.

\section{THE DIPPER}

\section{Cinclus aquaticus, Bechstein}

Wherever a mountain torrent is to be found in these islands we are almost sure to find this bird, as he sits on a boulder which juts out among the rushing water. In shape he resembles the more familiar Wren, but he is essentially a water bird, and seeks most of his food, which consists entirely of aquatic insects and their larvæ, in the bed of the stream.

Diving into the water it reaches the bottom by the aid of both wings and feet, and when there progresses, apparently, by its feet alone. 


\section{The Dipper}

The nest, placed in the crevice of a wall, often on the under side of a bridge or between two boulders in the centre of the stream, is a large domed structure of moss and leaves, having an elliptical entrance low down on one side.

Four to six dull white eggs form the clutch, and two or three broods are reared in the season, the first eggs being laid early in March. Its song is begun in autumn and continues throughout the winter till well on in spring.

A strictly resident species, this bird may be found in its haunts at all times of the year and is exceedingly common in Scotland, where there are few burns that are not tenanted by two or three pairs. In hard frosty weather, however, when its natural home is frozen and food scarce, it wanders over the country and may at such times be found by tidal ditches on the sea-shore.

Its flight is rapid and direct, and when on the move it almost invariably follows the course of the stream.

The adult has the head and neck brownish, rest of the upper parts dark slate grey. Chin, throat and upper breast white, lower breast chestnut, passing into black on the flanks and belly. Bill blackish, legs brown. The young lack the chestnut on the lower parts. Length 7 in.; wing 3.6 in.

\section{THE BEARDED REEDLING}

\section{Panurus biarmicus (Linnæus)}

Extremely scarce and local in our islands, being confined to not more than half-a-dozen localities, this charming little 


\section{Birds of Britain}

bird, more than any others perhaps of our rarer species, is worth a journey to see. Inhabiting large and extensive reed-beds, it used formerly to be abundant in the fens of Huntingdon, Cambridge, and other eastern counties, but with the reclaiming and draining of the land it has slowly died out, only holding its own in those few places where Nature still reigns supreme. Its exact systematic position is doubtful, as it shows no close affinity with any other known species; one point, however, is absolutely certain, namely that its popular name of "Tit" is quite a misnomer, as it has no connection in appearance or habits with those delightful birds. The naturalist, therefore, who goes to visit him at home must not search for him on trees or look for his nest in holes. As the boat glides quietly past some reed-bed his first acquaintance of this bird will be the clear and unmistakable "ping-ping," a note answered almost immediately by another close by. Soon, if he remains quiet, he will see a small light-brown bird with long tail rise from the reeds and, progressing with undulating flight, settle again a short distance on. Although very tame and unsuspicious, the Bearded Reedling is very hard to watch, owing to the thickness of the reeds in which he lives, but if we wait about patiently we can see a good deal of him as he searches the mud at the base of the reeds for minute molluscs, of which he is extremely fond. These he swallows whole, and having exhausted the treasures of one spot he will run up two reeds, resting one foot on each alternately, with surprising rapidity and then fly off with a merry "ping-ping" to renew his search in some other spot, and possibly, if the place be more open, we may see him scratch 

BEARDED REEDLING

Panurus biarmicus 


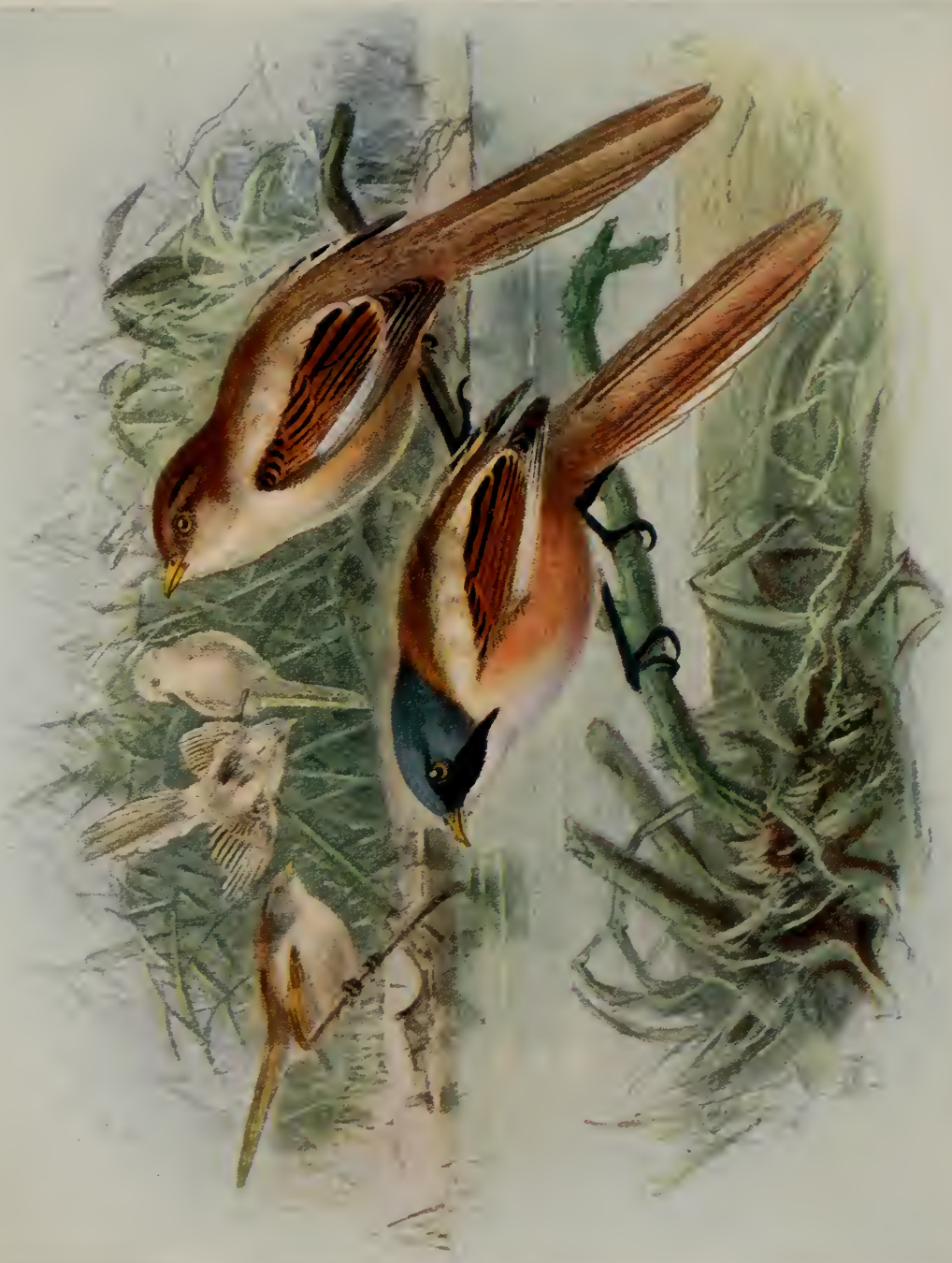





\section{The Bearded Reedling}

up the soft ooze with a peculiar backward motion of both feet and then eagerly scan the spot to see if his labours have met their reward. Early in April he pairs, and a nest of leaves and rushes, deeply cup-shaped and lined with the feathery tops of the reeds, is built. Materials are collected by both sexes, but especially by the cock, while the building itself is entirely carried on by the hen. A clutch of six eggs is laid; they are very round in shape and dead white, freckled with minute black markings. Two broods are reared in the season, the young being fed chiefly on insects. It is essentially a resident species and spends the whole year wandering over the reed-beds in family parties, feeding on insects, molluses, or seeds, the party keeping together by a continual use of the call-note. At nightfall they all gather close together on some broken reed, where they sleep securely till dawn awakens them to another day of restless work and energy.

The general colour above is tawny orange, the secondaries are striped with rufous buff and black, the tail is long, wedge-shaped, and of the same colour as the back. Chin and throat whitish, becoming pinker on the breast and passing into tawny brown on the flanks; under-tail coverts black. The male has the crown of the head a delicate grey and a black moustache of elongated feathers running downwards from the lores and beneath the eye. In the females this moustache is wanting and the crown of the head is brown, but otherwise they resemble the male. The young differ from the female in having the crown and back striped with black. Length 6.75 in.; wing $2 \cdot 25$ in. 


\section{Birds of Britain}

\section{THE LONG-TAILED TIT}

\section{Acredula caudata (Linnæus)}

There must be few of us who have not noticed this charming little bird when we are walking in winter along a hedgerow. We are attracted by a high-pitched "zi-zit" as the bird darts from the hedge in front of us, and after a few yards of undulating flight settles again. It is not alone, for another and yet another Tit follows till the whole family party are busy at work hopping and creeping about the hedge. Shortly the whole proceeding takes place again, the family procession moving on to search for food in a new spot. All this goes on daily during the winter months; up one hedgerow, down another; now hopping up a tree, occasionally visiting a small wood, ever on the move, and ever restless, till the evening comes, when the little party gather to rest, sitting close to each other on some slender bough.

In April, however, this roving life ends. The cock bird seeks a mate and they proceed to make a summer home, sometimes in an open hedgerow, but more often in the hedge bordering a wood, or in some isolated bush in the wood itself. It would be difficult to imagine anything more beautiful than their nest, which is perhaps the most elaborate of any of our British Birds! It is a solid thickwalled elliptical mass of felted moss completely covered externally with lichens, which are largely interwoven by means of cobwebs. The entrance, for it is entirely covered in, is towards the upper end, and the interior is lined with 






\section{The Long-tailed Tit}

horsehair and innumerable feathers, as many as seven hundred having been counted in a single nest.

The full complement of eggs is at least ten, and two broods are often reared in a season.

This species is entirely insectivorous and less destructive to the buds of fruit-trees than any other kind of Tit, so that no one can have any excuse for destroying this beautiful little bird that does so much to brighten our hedgerows during the dull months of winter.

The sexes are alike. The forehead and crown are white, bordered by a dark stripe, which runs from the bill over the eye to join the black of the nape and back. Wings dark brown; scapulars and rump pinkish; tail feathers black, the three outer pairs broadly tipped and margined with white. Under parts dull white and tinged with pink on the flanks and belly. The young are duller. Length 5.5 in. ; wing $2.4 \mathrm{in.}$

Continental specimens are said to be distinguishable from our native birds.

It is common throughout our islands except in Scotland, where it is somewhat local.

\section{THE GREAT TIT}

\section{Parus major, Linnæus}

On a bright morning in winter, when the leafless branches of the trees bear white traces of the night frost, whose tonic power is felt by man, as well as the lower 


\section{Birds of Britain}

orders of Nature, we shall not walk far before the rasping "che-chi, che-chi" of the little Saw-sharpener, as he is often called, breaks on our ears. We soon see him climbing about on the branches of some wayside tree; never still, now hanging head downwards as he inspects a bud, seeking for the insect it may contain, or plucking some berry he holds it between his feet, and with a few sharp hammerings of his powerful little beak breaks it open, swallows the seed, and then flits on to the next tree to resume his untiring search for food. Bright in colour, lively in habits and in song, he is such a cheery little fellow that we cannot help regretting the antagonism that is bound to exist between him and the gardener, as the latter watches his promising buds ripped off by this gay-plumaged marauder. True, he is seeking the insect contained in the bud, but in that search it is not to be denied that many an unaffected bud has to suffer. Woods and orchards are his chief haunts, but gardens are frequently visited, and if nest-boxes with small holes be hung up on the trees round the house he and his mate may often be induced to hatch and rear their family under our protection and observation. In spring his sawsharpening note becomes elaborated into a merry little song, and he proceeds in company with his mate to choose a nesting-site - this is always in a hole in a wall or tree, or even in a letter-box; the cavity within may be fairly large, but the entrance thereto is often very small-ridiculously so for the size of the bird. The nest is a large accumulation of moss, the whole space being filled up level and a little cuplike hollow being sunk in part of it. About ten eggs, white with a few reddish-brown blotches, are laid. The hen bird 76 
GREAT TIT

Parus major 


$$
\text { 篎 }
$$





\section{The Coal Tit}

sits very closely and vigorously pecks at any intruding hand. The period of incubation is very short, being only from ten to twelve days, and the young, which are fed almost exclusively on insects, leave their home in about a fortnight, and wander in small parties through the woods and lanes for the rest of the year.

The sexes are alike in plumage. The whole of the head, chin, throat, and a median line running down the breast are of a glossy blue black; cheeks white; mantle yellowish olive, prolonged forwards to end in a light spot on the nape ; wing coverts and tail bluish grey, quills darker. Under parts greenish yellow. Length 5.75 in.; wing 2.85 in.

The young are somewhat paler, but otherwise resemble their parents.

A common resident throughout the whole country, except the extreme north.

\section{THE COAL TIT}

\section{Parus ater, Linnæus}

The Coal Tit is often found as a near neighbour of the Blue Tit, but is never so abundant and familiar. It prefers clumps of trees bordering open commons and moors, but it may sometimes be seen on the outskirts of woods.

The nest is always placed near the ground, in either a hole of a post or tree, and not infrequently, when suitable holes are scarce, mouse-burrows in the ground itself are chosen. It is chiefly composed of moss and lined with hair 


\section{Birds of Britain}

and feathers, and the eggs, eight to ten in number, are white speckled with brown, much resembling those of other Tits.

The young are fed entirely on insects, and after leaving the nest wander about in family parties, gradually scattering over the country, but seldom becoming so familiar in the haunts of man and vicinity of towns as the Blue Tit.

The sexes are alike. The head, neck, and upper breast are a glossy blue black; the cheeks and a nuchal spot white; back grey, browner on the rump; wing coverts tipped with white to form two bars. Breast whitish, passing to pale brown on the flanks and belly. Length 4.25 in.; wing $2 \cdot 4 \mathrm{in}$.

The young lack the gloss on the head, and the white cheeks and nape are tinged with yellow.

This species may readily be distinguished from the Marsh Tit by the white nuchal spot.

\section{THE MARSH TIT}

\section{Parus palustris, Linnæus}

This bird is the rarest of our common species of Tits, although in some places it outnumbers the Coal. In habits it is very similar to its congeners, but is perhaps more partial to young alder and willow plantations than some of the others. Its name would lead us to suspect that it especially frequents marshy spots, but this is not the case. It chooses for its nesting-site a hole in some decayed stump which it not infrequently hews out for itself, and the nest 
MARSH TIT

Parus palustris 


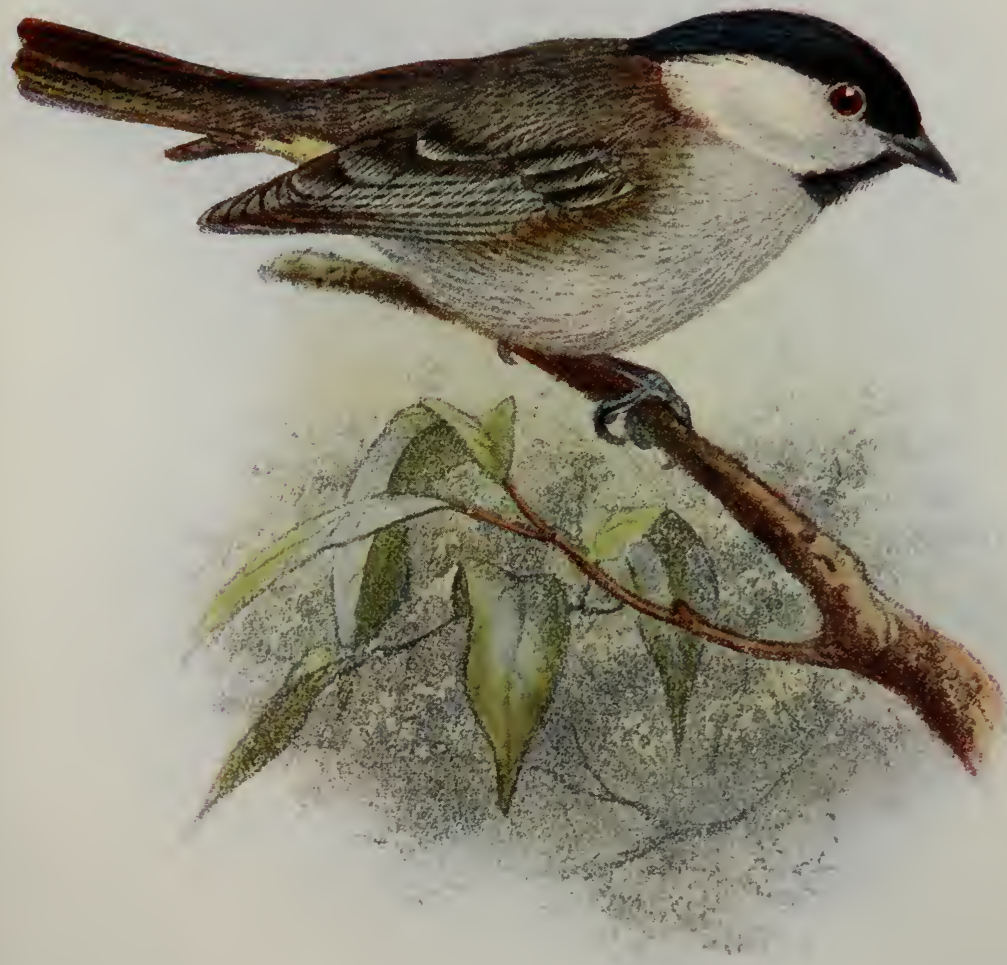





\section{The Marsh Tit}

consists of the usual materials, but sometimes willow-down is used in addition for a lining, a material never found in the nests of other Tits.

The note is a three-syllabled chirp bearing a family resemblance to that of the other species. The food consists of insects and seeds of various kinds which it seeks with the unceasing energy characteristic of this genus.

The sexes are alike and of an olive brown colour on the back; head and nape glossy black; cheeks white; chin black; under parts whitish, becoming buff on the flanks. Length 4.5 in. ; wing 2.45 in.

The young are duller and have no gloss on the head and nape.

This species is local, but well distributed in England and Wales; in Scotland it is rare and only recorded from two or three counties.

Recently it has been suggested that there is in our islands another species of Tit ( $P$. salicaria) called the Willow Tit. Except that in habits it is apparently more local and restricted to marshy places, there seems to be little to distinguish it, and in plumage it is practically identical with the young Marsh Tit, the absence of gloss on the head being the most characteristic feature.

\section{THE BLUE TIT}

\section{Parus cœruleus, Linnæus}

This bird is very similar in its actions to the Great Tit, but is more often seen in gardens than the latter. It is 


\section{Birds of Britain}

ever on the move and is extremely fond of a bit of sueta piece hung on a string in the garden affords throughout the winter months endless opportunities of watching its pretty and fascinating ways. In summer, sunflower seeds are a great attraction; these are removed as soon as they ripen, and taken to some convenient post or branch ; there he will hold one between his feet and split it with a few welldirected blows of his bill, and having swallowed the tender kernel he will return again and again to the same sunflower until not a seed is left.

Any dark cavity will suit it for a nesting-site, either a hole in some tree or post, an old tin carelessly thrown in a hedge, or some artificial nest-box in the garden, but it will rarely be nearer the ground than about six feet. It has a very short but bright song, which may often be heard in spring, and its call-note is a single "tzee."

It is a very common resident, wandering in small parties all over the country during the winter months and even penetrating the heart of our large cities, where it becomes very tame and confiding.

The sexes are alike in plumage. The back is yellowish green; tail and wings blue; wing coverts tipped with white; the crown is cobalt blue encircled by a white line running backwards across the forehead. The chin is blue, and a blue line runs through each eye to the nape, and, encircling the white cheeks, runs forward again to meet the blue chin. Under parts sulphur yellow with a black streak down the centre of the chest. Length 4.3 in.; wing $2 \cdot 4$ in.

The young are very similar but rather duller in colour. 80 

NUTHATCH

Sitta casia 


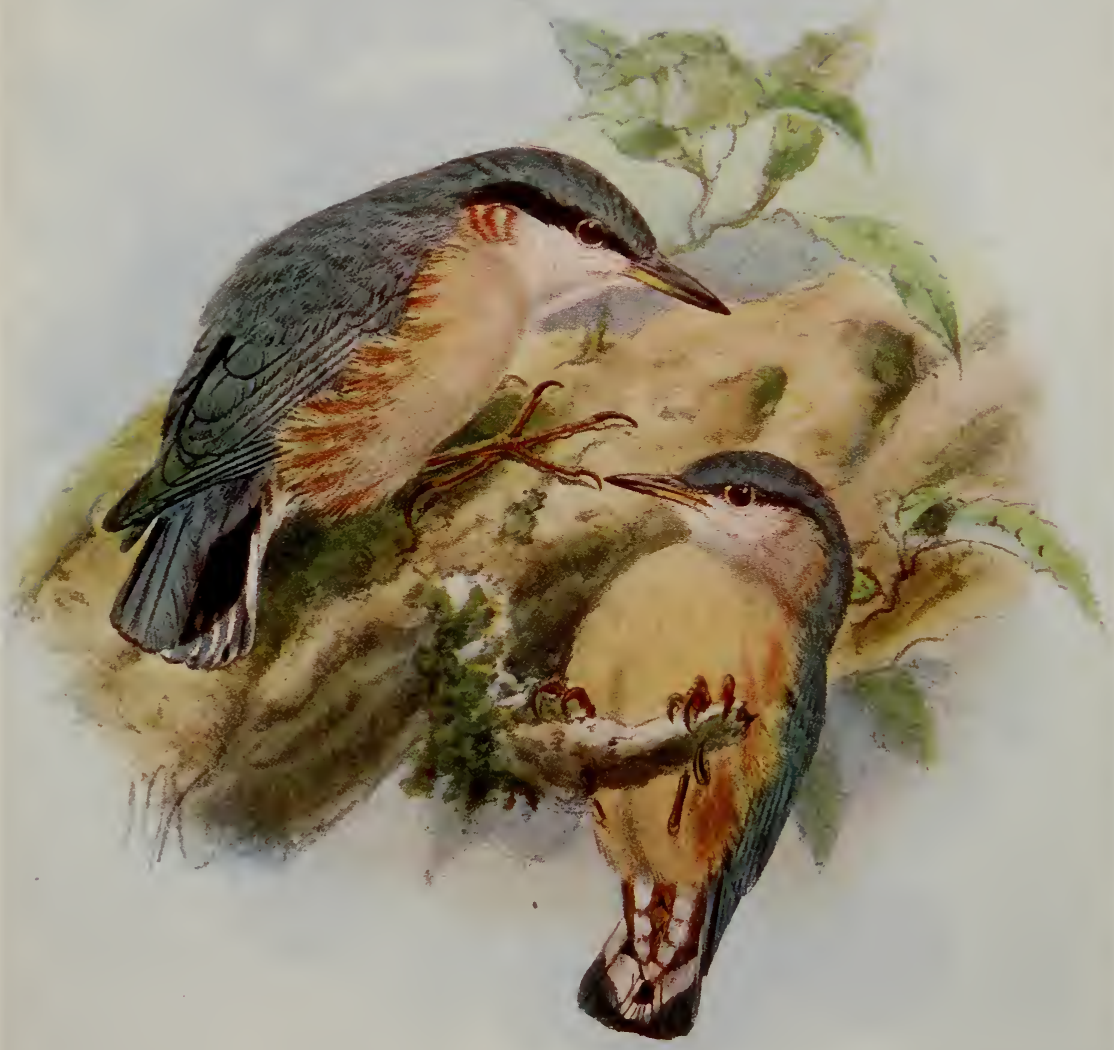





\section{The Blue Tit}

It is common and generally distributed throughout our islands, becoming rather scarce and more local in the northwest of Scotland.

\section{THE CRESTED TIT}

\section{Parus cristatus, Linnæus}

A few favoured spots in Scotland are the only resorts of this bird in our islands.

It is a forest species, haunting pine woods, from which it seldom wanders far. Like the Marsh Tit, it frequently excavates its own nesting-hole, which is generally at no great distance from the ground. In all its actions and habits it resembles its congeners.

The sexes are alike. The general colour above is olive brown, beneath white, turning to buff on the flanks. The feathers of the head are black, broadly edged with white and prolonged into a conspicuous crest. A black streak runs backwards from the eye on each side to join its fellow on the nape, whence it turns forward and encircling the cheeks, which are white mottled with black, joins up with the black chin. Length 4.5 in.; wing 2.5 in.

The young are duller and have hardly any crest.

\section{THE NUTHATCH}

\section{Sitta cæsia, Wolf}

The Nuthatch is fairly well distributed over the woodland portions of our southern and midland counties, 


\section{Birds of Britain}

becoming rarer towards the north. In Scotland it has only been observed in a few counties, and has never been met with in Ireland.

It is a very shy bird, but is most interesting to observe, as he runs up and down with extreme facility, assuming, as he does so, many graceful and curious positions. Unlike the Woodpeckers, which only run up the trees, it seems quite immaterial to this species whether he be going up, down, or sideways, forwards or backwards, for in all positions he seems equally at home. He will be more often heard than seen as the sharp, shrill note will betray his whereabouts, though by keeping on the far side of the tree he avoids being seen. Insects are largely eaten in summer, but seeds, berries, nuts, and beechmast form his chief food. Nuts and hard seeds are taken to some convenient crevice in the bark and hammered with the sharp, hard bill until an entrance having been effected, the kernel can be pulled out and eaten. Some hole in a tree or wall, or more rarely in a bank, is chosen as the nesting-site; the entrance is generally plastered up with mud till only a small circular hole, just large enough to admit the bird, is left. The inside of the cavity is lined with a few leaves and scraps of bark on which five to seven eggs, boldly marked with reddish brown, are laid. These eggs bear a close resemblance to those of the Great Tit, but are, as a general rule, rather larger. In the courting season the male has a pretty little song, and "shows off" to the female as he chases her up and down the trees. It is a strictly resident species and may be found in the same spot throughout the year. 

COMMON WREN

Troglodytes parculus

Lower figure St. Gilda variety 


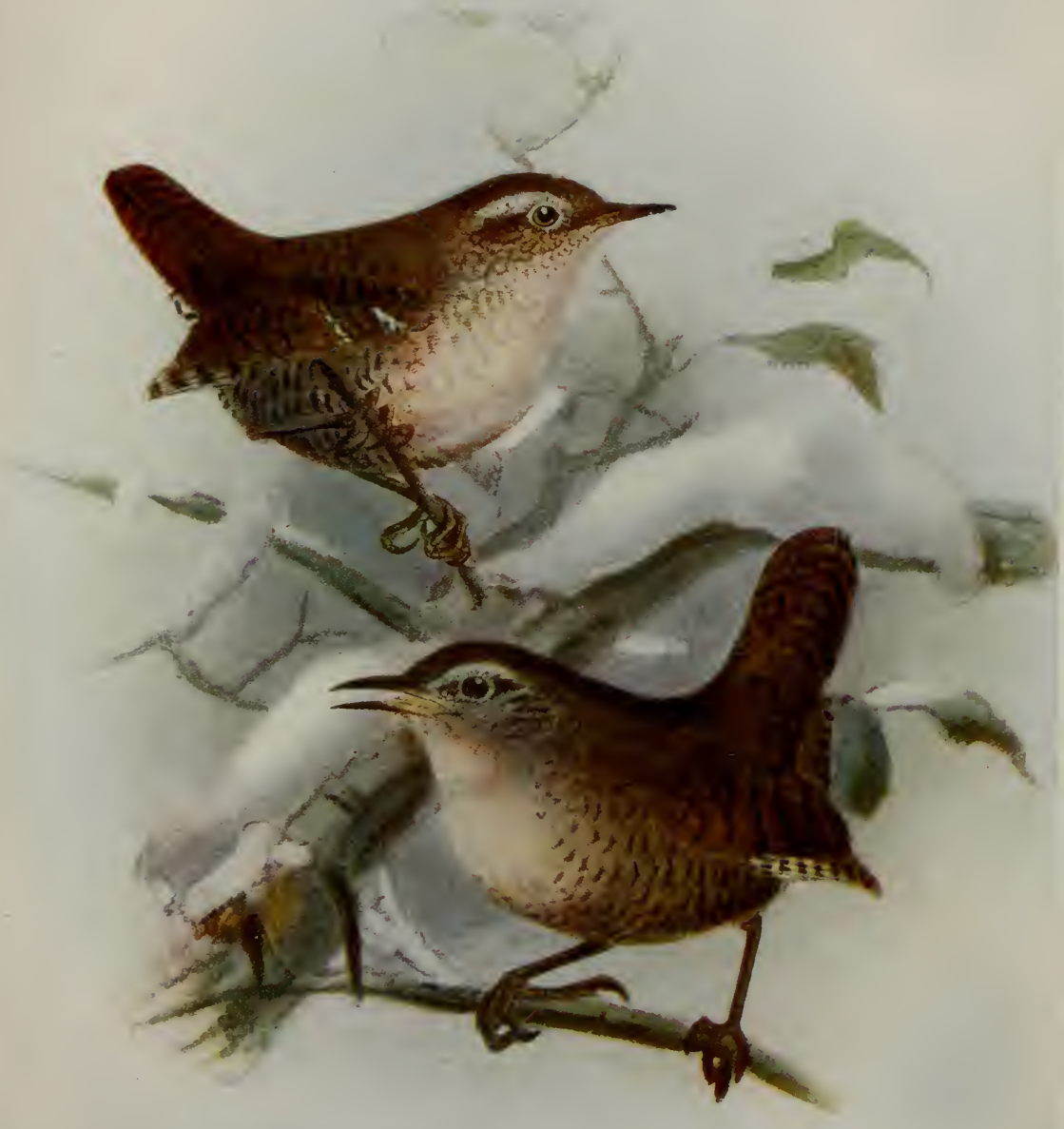




\section{The Nuthatch}

The general colour of the upper parts is bluish grey, but all the tail feathers, except the central pair, are blackish, barred and tipped with white and grey. A black stripe runs through the eye from the base of the bill. The under parts are pale rufous shading to chestnut on the flanks and under-tail coverts. Length 5.7 in.; wing 3.4 in.

The female and young are rather duller in colour.

\section{THE WREN}

\section{Troglodytes parvulus, K. L. Koch}

There must be few people who have not heard a long and clear song sounding almost at their side, when walking along some garden path or along the edge of a wood, and on investigation have found that this song, so disproportionate in volume to the size of the bird that utters it, proceeds from one of the smallest of our birds, the Wren. Skulking as a rule in the thick hedge bottom, among undergrowth in woods, or in a tangle of brambles on a common, he will suddenly hop on to an outstanding spray, rattle off his little song, and then with quick whirring beats of his wings dive into the undergrowth again a few yards off. Always bright and perky as he hops along, with his short tail held up at right angles to the body, he searches for any small seeds or insects which he can find, and as he appears so cheerful, even in the most severe weather, it is not surprising that he has won a way to our hearts, and next to the Robin is the most favoured bird in England. The nest is a beautiful 


\section{Birds of Britain}

domed structure, very cleverly concealed among the ivy on a wall or tree, or sometimes in a grassy bank or the side of a stack. It is composed of leaves, moss, bents, etc., so arranged and chosen as to harmonise well with its surroundings. The entrance is a narrow round hole, and the interior is warmly lined with hair and feathers.

Nest-building seems to be an occupation in which these birds delight, and several nests are generally built by each pair; one only, however, is lined, the others being left quite rough inside. These so-called "cocks' nests" are used, however, as roosting-places, and if the eggs be destroyed they may be lined and used as their home for a second clutch. The eggs, six to eight in number, are white, sparsely spotted with red. In this country the wren is a resident and seldom wanders far from its home, a habit which has resulted in the birds inhabiting some of our outer islands, like St. Kilda, becoming recognisable as distinct from the mainland form. In winter, however, our native stock receives considerable additions from the Continent, but a return migration in spring has not been noticed.

The whole bird is of a uniform reddish brown, rather lighter on the chin and throat, minutely barred with black. There is a dull white streak over each eye. Length 3.5 in. ; wing 1.9 in.

The female is rather smaller and duller, and the young are less distinctly barred. 



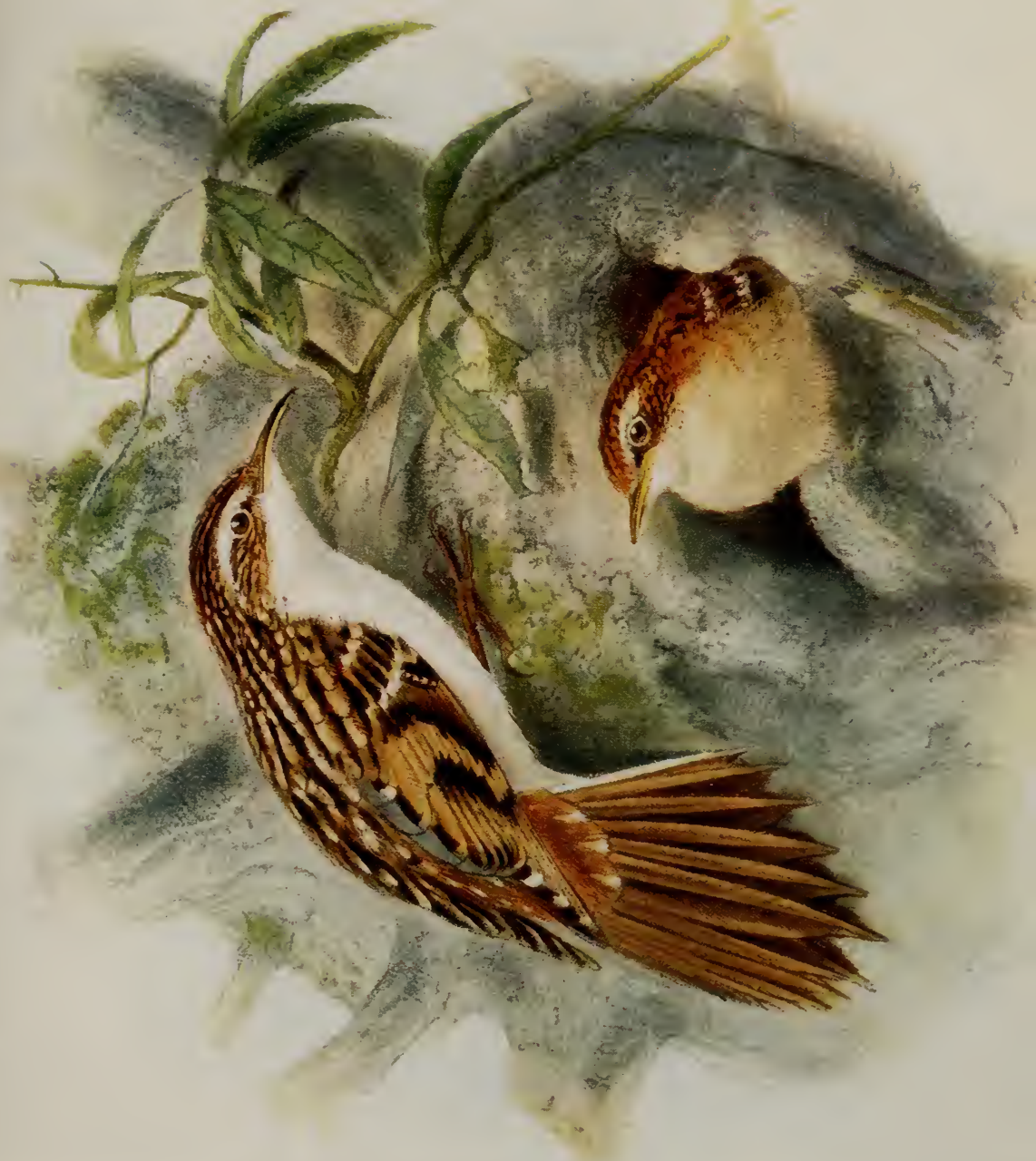





\section{The Tree-Creeper}

\section{THE TREE-CREEPER}

\section{Certhia familiaris, Linnæus}

The Tree-Creeper is a common species, but from its quiet ways and dull colour seldom noticed. It is with us the whole year, spending its time in an unceasing search for small insects on the bark of trees. In its habits and food it is not unlike the Woodpeckers, climbing up with a series of jerks, and, when observed, shifting at once to the far side of the tree.

It has a short but pleasing little song, which is not often heard, and the call-note is a low and plaintive "cheep." It is solitary in habits, and more than one are seldom seen together, except in the breeding season. The nest is placed behind a piece of loose bark and is merely an accumulation of roots, grass, and moss, with a lining of wool and feathers. The eggs are white, minutely spotted with reddish.

The sexes are alike and have the feathers of the upper parts dark brown with pale centres, becoming lighter on the rump; under parts, silvery white. Flight feathers dark brown, barred with buffish white. Tail feathers stiff and pointed and dull reddish brown in colour. Length $4 \cdot 75$ in.; wing 2.5 in.

It is common and abundant throughout our islands.

\section{THE WALL-CREEPER}

\section{Tichodroma muraria (Linnæus)}

Very few examples of this species, whose home is in the mountainous regions of Europe, have occurred in these 


\section{Birds of Britain}

islands. It spends its life climbing over the bare and precipitous surfaces of rock, searching for spiders and other insects on which it feeds.

The general colour is slate grey with crimson wing coverts and a black throat. The tail feathers are not stiff as in the preceding species. Length 6 in.; wing 3.9 in.

\section{THE PIED WAGTAIL}

\section{Motacilla lugubris, Temminck}

"Chizzit, chizzit," and looking round we see our little grey friend as he passes with his peculiar and characteristic dipping flight across the field towards the ivy-clad wall. Every year he comes with unfailing regularity to rear his brood near the same spot. It is an old red-brick wall, thickly covered with ivy, which has concealed the various nooks and crannies brought about by the winter's frosts and the heat of the summer sun. In such a place the Pied Wagtail delights to build his nest. Although not strictly speaking a migrant, for some individuals spend the whole year with us, he nevertheless appears with unfailing regularity towards the end of April at his accustomed haunt, and probably brings his mate with him, for we seldom see more than a pair together at their breeding quarters, and thus quietly, and without any demonstration, the nestbuilding is begun. This is usually done in the very early hours of the morning, and the day is spent in some neighbouring field among the cattle, with occasional excursions to 

PIED WAGTAIL

Motacilla lugubris 


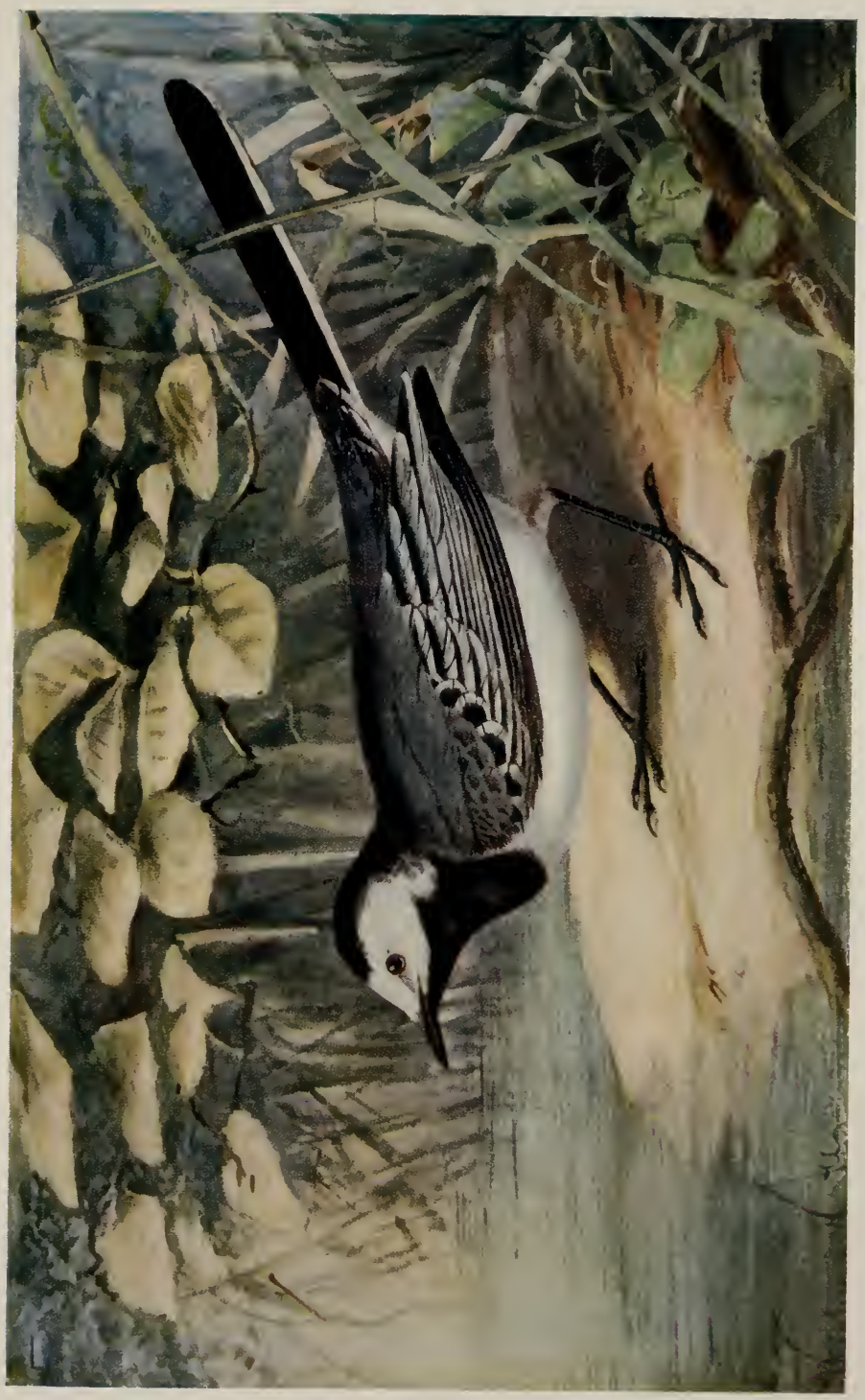





\section{The Pied Wagtail}

the side of the stream for the frequent bath which has earned for this species the name of "Polly Dishwasher."

When the nest, which is composed of grass and bents lined with horsehair, is completed, the six grey and speckled eggs are laid and incubation, which is solely carried on by the hen, begins.

If we did not know the habits of our friend, the first signs of his presence in the garden would be when he flies up to feed his mate with some special titbit, and then as he jumps out from the ivy we see him winging his way with elegant flight across the meadow to his favourite feedingground. In due course the young are hatched, and as the needs of the growing family become greater, we can often see the parents coming and going with unceasing energy till night brings compulsory rest to their labours. When the young leave the nest they are almost immediately taken into the grass fields, where the flies, attracted by the feeding cattle, offer them an easy livelihood.

September comes, and in company with the Meadow Pipits, they wander over the country and along the salt marshes near the sea previous to seeking other countries, or settling in the warmer parts of England near some sheltered farm where they may find food until the returning spring reminds them of their old haunts, or impels the younger generation to seek a mate and home.

In winter the sexes are alike, and grey in general colour with dark wings and tail (except the two outer feathers, which are white), while the inner secondaries are also broadly edged with white; under parts white.

In summer the chin and back are black, the forehead 


\section{Birds of Britain}

and a stripe across the face being white. Length $7 \cdot 3$ in.; wing 3.5 in.

The young bird resembles the adult in winter, but the white portions, especially on the throat and breast, are tinged with yellowish and the breast is slightly spotted.

This bird is generally distributed throughout the British Isles, rarer in the north and resident in the warmer portions of the south and west.

\section{WHITE WAGTAIL}

\section{Motacilla alba, Linnæus}

This is the Continental form of the preceding species, which passes through the country every year on migration and occasionally stays to breed. In habits it is precisely similar to its congener the Pied Wagtail. It may be distinguished by its rather lighter colour, and in summer it retains the light grey back but assumes the black chin.

The females, however, of our own species frequently do not assume a black back, so that the colour of the back when seen in the field will not be sufficient to identify this species. When it can be closely compared it may always be recognised by the clearer grey of the back and pure grey upper tail coverts. In the Pied Wagtail the mantle has a greenish tinge, and the proximal tail coverts are nearly black. Length 7.5 in.; wing 3.5 in. 

GREY WAGTAIL

Motacilla melanope 


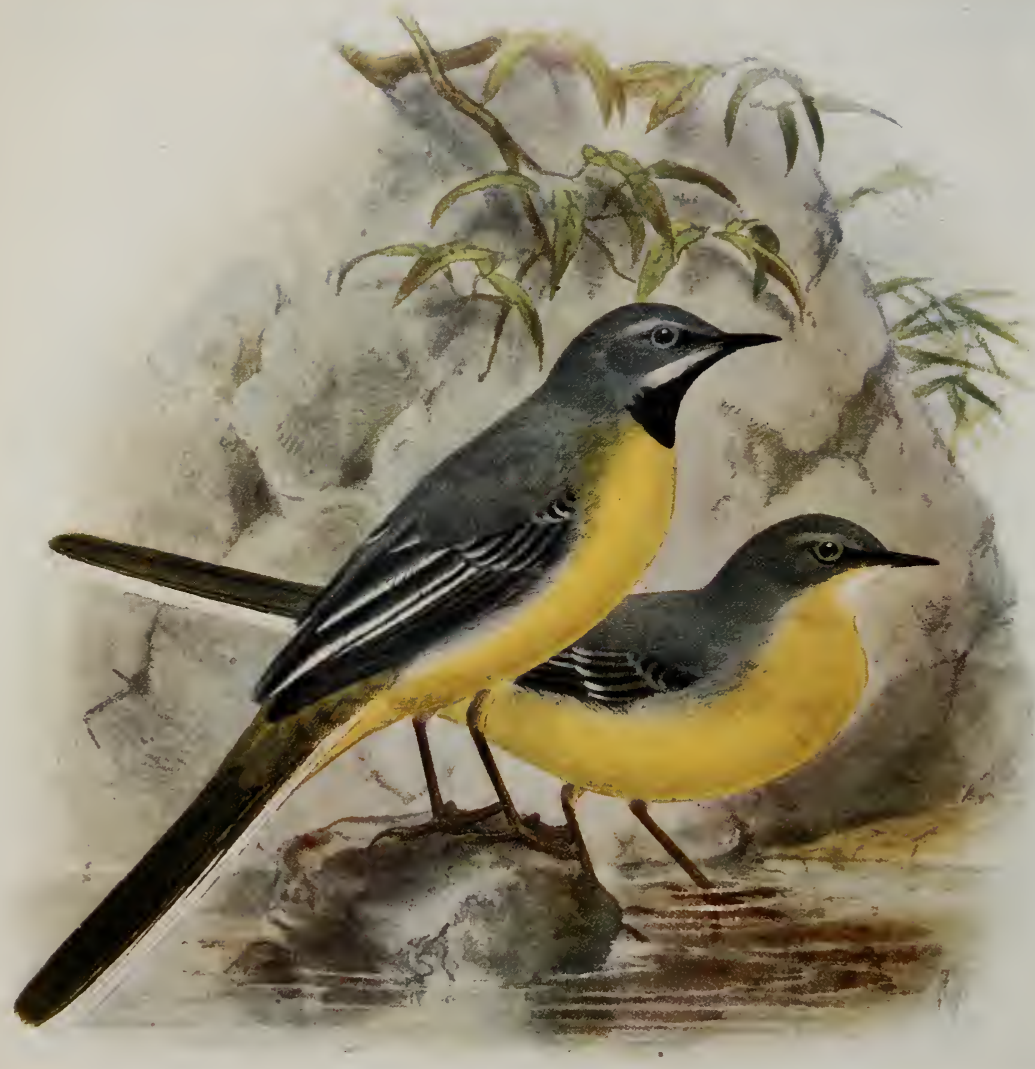





\section{Grey Wagtail}

\section{GREY WAGTAIL}

\section{Motacilla melanope, Pallas}

The Grey Wagtail is a close inhabitant of rocky streams, and we have to go to the more mountainous parts of our islands to find this species " at home."

Like the Pied Wagtail it is a partial migrant, seeking the warmer portions in the south and west during the winter and moving back to the same rushing streams with the return of spring.

The nest is placed in one of the loose stone walls so common near its haunts, or on the ground in some cleft of the rocks. The eggs resemble those of the Yellow Wagtail, but are slightly larger.

It is a very handsome bird, the handsomest perhaps of all our Wagtails. The back and upper parts are of a deep bluish grey: wings and tail (except the two outer feathers, which are white, a characteristic of all wagtails), dark brown; under parts clear lemon yellow, paler on the vent. Length 7 in.; wing 3.3 in.

Female and young resemble the male, but are paler. In summer the male has a jet black gorget.

This species has a much longer tail than our other species, the Yellow Wagtail having the shortest tail.

Generally distributed throughout our islands but only found during summer near rushing torrents, wandering at other times throughout the country, but always in the vicinity of running water.

The note is very similar to that of the Pied Wagtail. 


\section{Birds of Britain}

\section{THE BLUE-HEADED WAGTAIL}

\section{Motacilla flava, Linnæus}

This species resembles the Yellow Wagtail very closely in all respects, and is the common Continental "Yellow Wagtail," many different races of which are found. It occurs yearly in the south-east of England on migration and sometimes stays to breed.

The adults may be distinguished from our Yellow Wagtail by having the upper part of the head and neck, including the cheeks, bluish grey and the stripe over the eye white. Young birds are practically indistinguishable from those of our common species, but the eye stripe is constantly whiter. Length 6.3 in.; wing 3.2 in.

A closely allied race is $M$. beema, which breeds in Western Siberia and occurs on migration in India. It is very closely allied to $M$. flava, but is paler on the head and has the cheeks and chin white. This form has been taken in England on one occasion, viz. in Sussex, in April 1898. Faded and worn specimens of M. flava appear at first sight to belong to this form, so that excessive caution is necessary before finally identifying British specimens as belonging to this race.

The Scandinavian form, known as $M$. borealis, with a dark grey crown and no eye stripe, has been obtained on several occasions, and even remained to breed in Sussex in 1906.

M. cinereocephala, which has not yet been obtained in 90 

BLUE-HEADED WAGTAIL

Iotacilla faz'a (left)

Young (centre); var. melanocephala (right) 


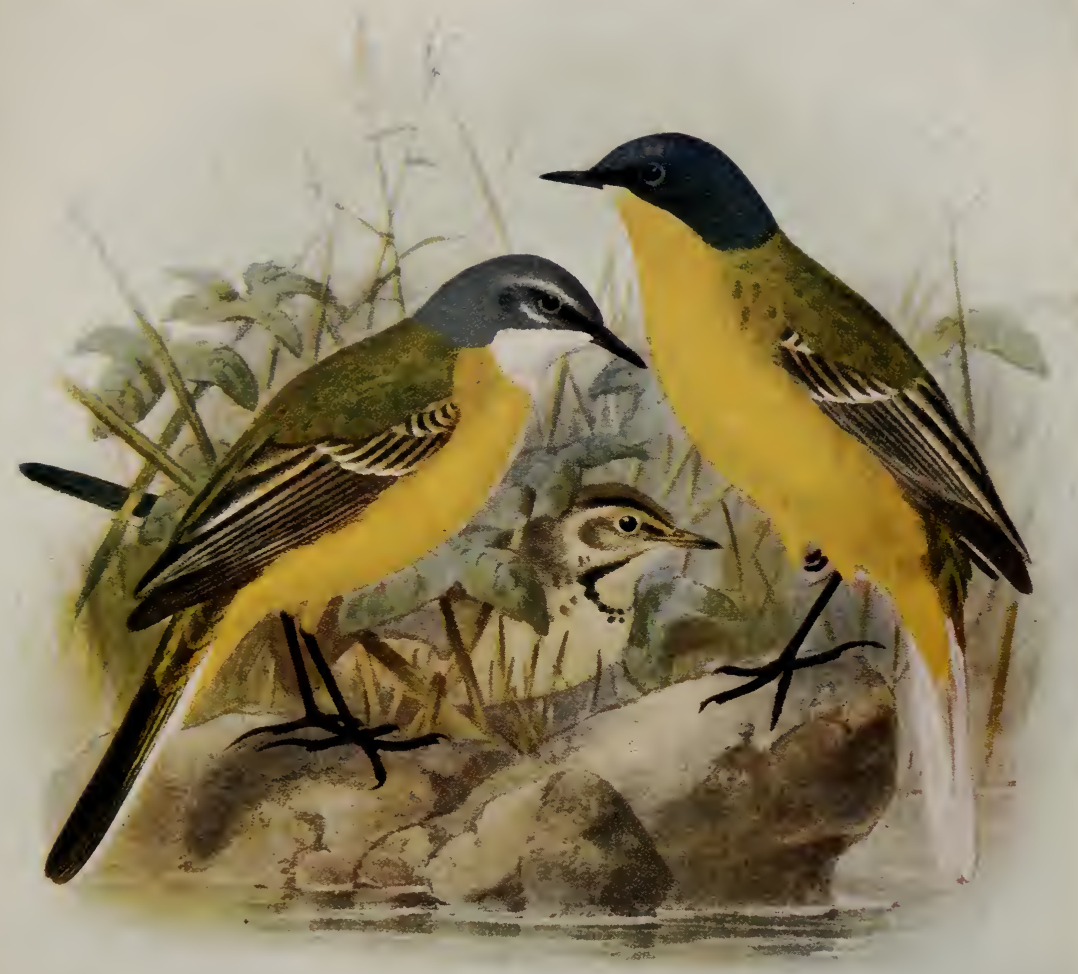





\section{The Blue-headed Wagtail}

England, but breeds in South Europe from Italy eastwards, may be recognised from $M$. borealis by its rather darker head and cheeks and by having the entire throat white.

Lastly, we have the Black-headed Wagtail, M. melanocephala, which inhabits South-eastern Europe and has a black head with hardly any trace of an eye stripe, and which was also obtained on the south coast in 1906 . In this form the cheeks and under parts, including the chin, are bright yellow.

\section{THE YELLOW WAGTAIL}

\section{Motacilla raii (Bonaparte)}

In the flat meadow-lands and pastures intersected by ditches or bordering some sluggish river, we may see this brilliant little fellow as he struts about under the feet of the cattle. At one moment he is running forward to pick some insect off the grass with an audible snap of his slender bill, and the next jumping up to seize, after the manner of the Flycatcher, some winged insect that has come within range of his sharp eyes.

This bird is a true migrant, reaching our shores during the latter half of April and leaving us again in September. The males arrive, as is the case with so many species, a few days before the hens, and on their arrival nest-building is begun without further delay. The site chosen is on the ground in the middle of an open field and generally near some upturned sod or in the deep footprints of the cattle. A few grass stems loosely laid together and lined with horsehair suffices for a 


\section{Birds of Britain}

nest, and the eggs, five to six in number, are of a pale claybrown with no spots or markings. The birds are very shy when at the nest, leaving it long before the intruder has approached, and only running on again when he is well away. The young are fed exclusively on insects, and when they are fledged remain in their summer home till shorter days and colder nights warn them that autumn has come. Old and young then collect in enormous numbers in the salt marshes along the sea-shore, until with favourable weather they pass on to warmer and more congenial climes.

The male above is of a uniform bright greenish yellow, with a yellow eye stripe; under parts bright lemon yellow. Females and young are similar but duller, the latter sometimes showing in autumn some dark spots on the breast. Length 6.25 in.; wing $3 \cdot 15$ in.

This bird is distributed in suitable localities throughout England, with the exception of the extreme south-west. In Wales it is chiefly seen on migration, and in Ireland it is only found nesting in a few places. In Scotland it does not nest north of Perthshire, and to the north of the Great Glen it is only a rare straggler. Abroad it is confined to North-west France and the Iberian peninsula, wandering in winter to West Africa.

\section{THE TREE PIPIT}

\section{Anthus trivialis (Linnæus)}

Arriving in April with our other summer visitors, the Tree Pipit may be found fairly commonly throughout 

TREE PIPIT

Anthus trivialis

(left)

MEADOW PIPIT

Anthus pratensis

(right) 


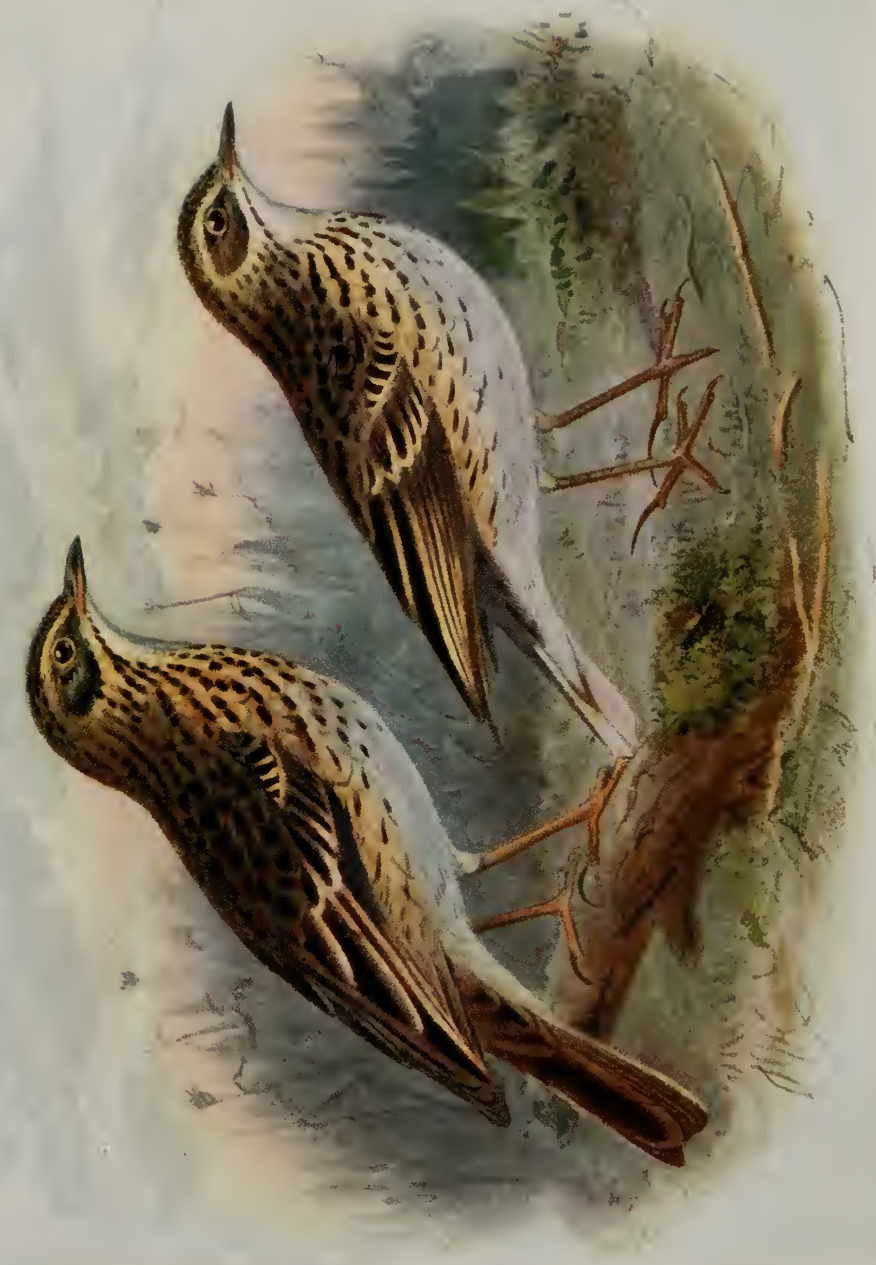





\section{The Tree Pipit}

England and Scotland, but becomes scarcer in the north. It has not yet been known to visit Ireland. It may be heard singing its pretty little song near the outskirts of woods, or in fields bordered by trees. This is usually uttered on the wing when, having sprung some distance into the air, it descends with fluttering wings and open tail to the same perch on the top of the tree from which it started. Most of its food is sought on the ground, and consists almost entirely of insects. The nest is placed in the middle of a field, or more preferably in some bank or railway cutting, and is composed of roots and bents with a little moss and lined with finer bents and hair. The eggs are generally six in number and vary considerably, the commonest variety being greenish white with bold blurred markings of dark brown at their larger end, another variety resembles this in markings but is suffused with reddish, while a third variety is uniformly and closely mottled with reddish brown.

In appearance, though not in habits, this bird somewhat resembles a lark. The upper parts are sandy brown with dark brown streaks, the wing coverts darker with conspicuous pale edging to the median ones. Chin white, breast and flanks buff with darker markings, rest of under parts white. Tail feathers dark brown except the two outer pairs, which show a considerable amount of white. Hind claw short and curved. The sexes are alike, but the female is slightly smaller. The young are rather more spotted. Length 6 in.; wing 3.3 in.

Common in England and south of Scotland, rather scarcer in Wales and rare in North Scotland. Does not visit Ireland. 


\section{Birds of Britain}

\section{THE MEADOW PIPIT}

\section{Anthus pratensis (Linnæus)}

Bleak and dreary moorlands, or wide wind-swept marshes and water meadows form the haunts of this bird at all seasons of the year. Hatched in a neat nest, placed on the ground and carefully concealed under a tussock of grass, the young Meadow Pipit is assiduously fed by both its parents on insects, and his cradle would be most difficult to discover were it not that the parents, in their anxiety, hover round the spot calling out "peet, peet" in a plaintive and pained manner. The nest is made of grass and bents lined with finer grass and hair, and the clutch usually consists of six eggs, which are of a uniform brownish grey colour, frequently mottled or clouded with a darker shade and having sometimes a narrow black hair streak at their larger end. Several broods are reared during the season. After quitting the nest, they remain about their home, feeding on insects or small seeds and joining in flocks with the Wagtails and others of their own kind. Towards September they become restless and slowly move southwards, the majority quitting our shores for warmer climates; their place is, however, soon taken by wanderers from farther north that stay with us, braving our winter gales. They are graceful little birds, running about the fields rather like a Wagtail, picking up an insect from a blade of grass, or jumping up in the air and catching a fly as it hurries along in the genial warmth of a summer's day. But on a winter's day, when 


\section{The Meadow Pipit}

the south-wester blows up the clouds and sweeps the rain across the desolate meadows, they seem equally happy and at home, and rising at one's feet from the shelter of a tussock fly off to another shelter, their "peet, peet" adding a harmonious touch of life to the discordant elements. In spring our summer visitors return, and then we may watch him as, full of energy, he rises some distance into the air and gradually descends with fluttering wings and outspread tail, singing his somewhat feeble song.

The adult is olive brown above, each feather having a darker centre, except on the rump and upper tail coverts; wing coverts margined with white; there is a narrow white eye stripe. Under parts buffish white streaked with brown on the throat, breast, and flanks. In autumn both old and young are much more buff' coloured. The sexes are alike Length $5 \cdot 75$ in.; wing $3 \cdot 1$ in.

\section{THE RED-THROATED PIPIT}

\section{Anthus cervinus (Pallas)}

Less than half-a-dozen individuals of this species, which breed in the far north of Europe and Asia, and winter in tropical Africa, have visited us, and with one exception they have all been taken on the shores of Kent or Sussex.

It closely resembles the Meadow Pipit, but in the breeding season the sides of the neck and breast in both sexes are vinous chestnut. All our examples, however, have been immature birds, which are extremely difficult to distinguish from our common species. 


\section{Birds of Britain}

The feathers of the rump form, however, the most distinctive character in this species; they have dark centres like those of the mantle, but in the Meadow Pipit, as we pointed out above, these feathers are of a uniform olive brown. Length $5.8 \mathrm{in}$; wing 3.5 in.

\section{THE TAWNY PIPIT}

\section{Anthus campestris (Linnæus)}

The Tawny Pipit is a regular summer visitor to the sand-dunes and arid wastes of Europe, breeding in some numbers no farther from our shores than the north of France and Holland. It winters in Africa. To England it has only been a scarce straggler, single examples having been obtained in autumn on our southern and eastern shores from the Scilly Islands as far north as Yorkshire. During the last year or two there is evidence that it may have bred in Sussex, adult pairs of birds having remained about the same spot during part of the summer till they were shot.

The general colour is pale sandy brown with dull darker centres to the feathers. Two outer pairs of tail feathers white with brown margins to their inner webs, rest of the tail brown. Under parts warm buff, slightly striated with brown on the breast and paler on the belly. Length 6.5 in.; wing 3.6 in. 


\section{Richard's Pipit}

\section{RICHARD'S PIPIT}

\section{Anthus richardi, Vieillot}

This eastern species breeds in Turkestan, Siberia, and Mongolia, but a large number yearly visit Europe during the autumn migration. In England a good many examples have been obtained, and closer observation may prove it to be a regular autumn migrant along our eastern and southern seaboard, as it is abundant on Heligoland every year. It has occurred once in Scotland and once in Ireland.

It is a large bird and may be distinguished by its long hind claw; when seen on the wing it appears very dark. The feathers of the upper parts are sandy brown with dark centres, but the rump is of a nearly uniform brown. Wing coverts tipped with reddish buff. Outer pair of tail feathers white with dusky margins to the inner webs, in the next pair the dusky margin is much broader, remainder of the tail feathers very dark brown. Chin white, margined with brown spots; breast buffish and thickly spotted; belly white. Length 7.25 in.; wing 3.75 in.

\section{THE WATER PIPIT}

\section{Anthus spipoletta (Linnæus)}

The Water Pipit breeds in the Alps, Pyrenees, and other mountain ranges of Central Europe, migrating in winter to the shores of the Mediterranean. A few odd stragglers 


\section{Birds of Britain}

have been taken in this country both in the spring and autumn migrations.

The upper parts are of a uniform greyish brown; under parts buff, paler on the belly and browner on the flanks. There is a short light stripe immediately above the eye. The tail feathers are brown, except the outer vane of the exterior pair and the tips of the second pair, which are white. This forms at all seasons and ages a mark by which this species may be distinguished from the Rock Pipit.

\section{THE ROCK PIPIT}

\section{Anthus obscurus (Latham)}

This species, which very closely resembles the Meadow Pipit but is slightly larger, is found along the rocky coasts of our islands.

It is strictly an inhabitant of the sea-shore and never wanders inland, but finds its food, which consists of flies, small mollusca, and marine insects, on the beach and rocks or among the rough tangle of sea-weed left dry by the retreating tide. The nest is placed on the ground, in some crevice of the rocks, or in a grassy bank, and the eggs, large for the size of the bird, are pale greenish grey, uniformly and densely mottled with olive brown. This species is largely migratory, and after the breeding season wanders round the whole of our coasts, inhabiting in winter the salt marshes and estuaries of our eastern and southern counties, as well as the more rocky portions of our shores. 


\section{The Rock Pipit}

Its song and call-note are almost indistinguishable from that of the Meadow Pipit, and if the nest be approached it flies restlessly from rock to rock, calling out all the time, but does not hover round in the air like the commoner species.

Birds from Scandinavia, Denmark, and the Baltic are distinguishable from our form, which is also found on the adjacent coast of France, in being of a vinous tint on the breast during the breeding season. The Scandinavian form may be found sparingly on our shores during migration.

The sexes are alike in plumage. The general colour above is olive brown with dark centres to the feathers; the under parts are greenish buff streaked with brown on the breast and flanks. The tail is brown, except the outer webs of the tail feathers, which are smoky grey, and this forms an easy characteristic by which this species may be distinguished from the Water Pipit, which it otherwise closely resembles. Length 6.25 in.; wing 3.5 in.

\section{THE GOLDEN ORIOLE}

\section{Oriolus galbula, Linnæus}

There is little doubt that this beautiful species, if unmolested, would become a regular summer visitor to this country. Every year during the spring migration several of these birds are seen and shot, chiefly in our southern and south-western counties, and there is no doubt that it has on several occasions successfully reared its young in 


\section{Birds of Britain}

this country. Its brilliant colouring unfortunately attracts the eye and the gun of those whose sole thought on seeing a rare bird is to kill it, and the large mass of nature lovers are thus deprived of the pleasure of a glimpse of this brilliant bird.

It breeds commonly over most of Europe, throughout France, Germany, and Russia, but is scarce along the countries bordering the North Sea.

The nest is suspended from the fork of a branch of some tree, usually in woods, and is a carefully woven structure of strips of bark and grass stems. The eggs are white with a few large black spots.

The male is golden yellow all over, except for the quills, wing coverts, and lores, which are black. The central pair of tail feathers are black, all the rest being black with yellow tips. Bill red. Legs lead grey. The female is greenish yellow and has the under parts striated with greyish. The young is still duller in colour than the female. Length 9.5 in.; wing 6 in.

\section{THE GREAT GREY SHRIKE}

\section{Lanius excubitor, Linnæus}

Every autumn towards the end of October a certain number of these birds regularly visit us, occurring more commonly on our eastern coasts, but having nevertheless been taken in most of our counties. In habits it resembles its small congener the Red-backed Shrike, and may be seen 


\section{The Great Grey Shrike}

sitting on some point of vantage from which it may dash off to attack its unsuspecting victims.

This species, or various races of it, breed throughout Northern and Central Europe and Asia. It migrates on the approach of winter from the more northerly quarters, but its wanderings rarely extend to the shores of the Mediterranean.

The male is pearl grey in general colour, lighter on the scapulars; forehead and a line over each eye white; lores and ear coverts black. Wings black, with white tips and bases to the secondaries and inner primaries. Tail feathers black with white tips, except the outermost, which are pure white. Under parts white. Bill and legs black. Length 9.5 in.; wing 4.3 in. Female duller with faint greyish bars on the under parts.

\section{THE LESSER GREY SHRIKE}

\section{Lanius minor, J. F. Gmelin}

The main home of this species, of which only a few examples on migration have been taken in this country, is South and Central Europe as far west as the valley of the Rhone.

In habits it does not differ from its congeners, and is excessively savage and pugnacious, especially during the nesting season.

It roughly resembles the preceding species in plumage, but may be distinguished by its smaller size, black forehead, 


\section{Birds of Britain}

and the white bases to the tail feathers and primaries, which latter form a broad bar. An unfailing characteristic, however, of this species, distinguishing it from all other Shrikes, is the wing formula; the first or bastard primary being very short, while the second nearly equals the third and longest primary. Length 8.5 in.; wing 4.6 in.

\section{THE RED-BACKED SHRIKE}

\section{Lanius collurio, Linnæus}

Arriving during the early part of May, this species is fairly common in our southern and south-eastern counties and in Wales during the summer months. In the northern counties its appearances are irregular, and on one occasion only has it been seen in Ireland.

One can somehow feel but little affection for this fine but cruel bird; it is not his fault to be in that stage of evolution in which as an insect-feeder he aims at higher prey than that with which he is successfully able to deal. Bold and pugnacious, he sits on the top of some thick hawthorn hedge, dashing down from his point of observation on some mouse, bird, or lizard nearly as large as himself.

After a tussle the hapless victim is carried off and impaled on a thorn near its captor's nest, to be eaten at a future time; it is these larders of impaled victims that have earned for him the name of Butcher Bird. Beetles, bees, and insects of all kinds are also included in his menu, and young half-fledged birds are considered a great delicacy. 

RED-BACKED SHRIKE

Lanius collurio

Adult male, female, and young 


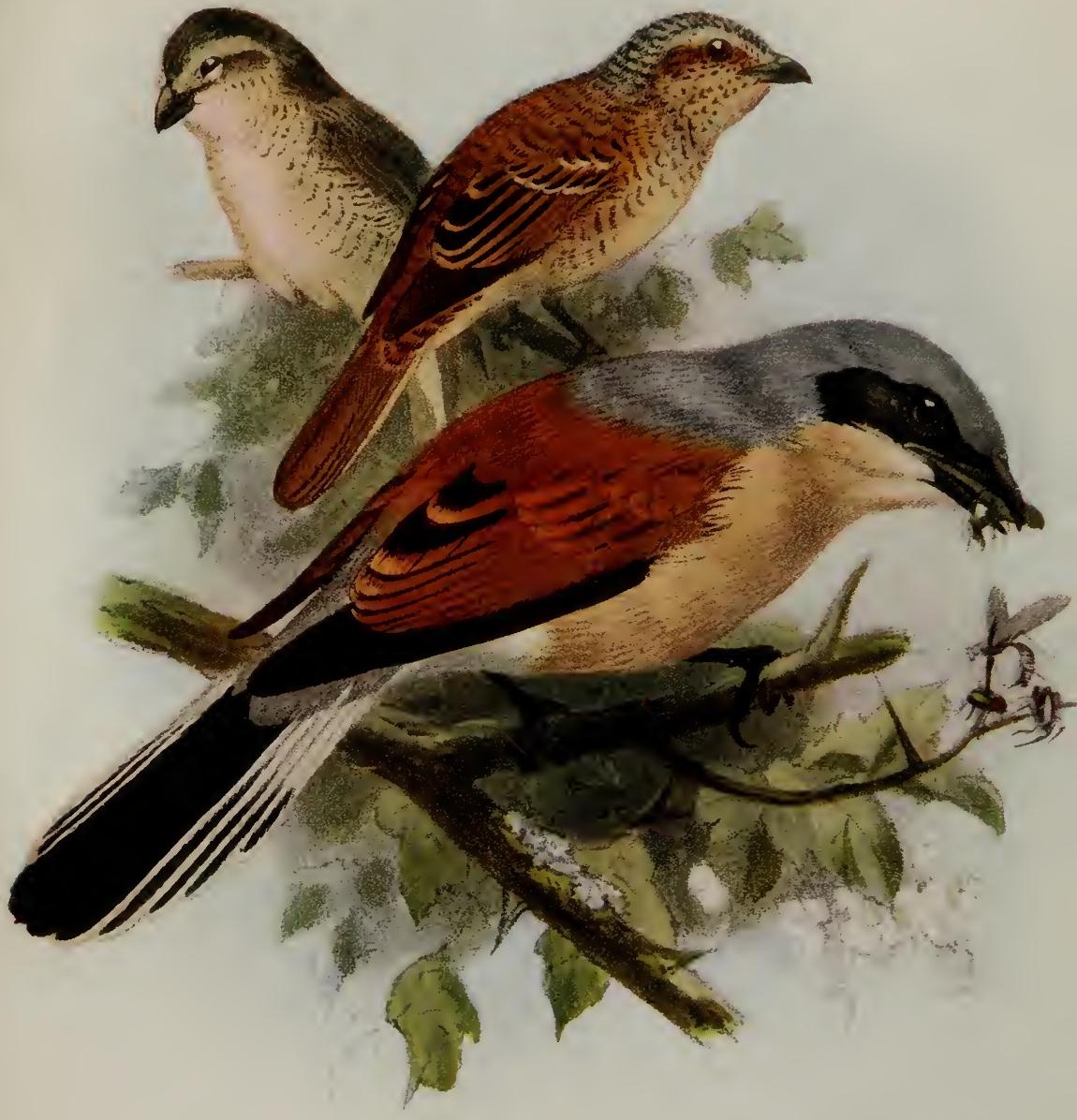





\section{The Red-backed Shrike}

The nest is a large and loose structure of twigs, roots, and moss; it is lined with hair and wool, and placed about eight or ten feet from the ground in a thick hawthorn hedge. The eggs are usually of a pale green colour, with a zone or band of olive brown mottlings round the larger end. In some districts a variety is found in which the ground colour is pinkish and the markings reddish brown. The Shrike has no song, but makes a great variety of harsh noises and chucklings as it sits on its post of vantage, bending down and flirting his tail at the same time. The call-note is a harsh "chack." Like the Swift, Cuckoo, and several other species, he does not stay with us long, but having reared his brood, the whole family wander south, and soon leave our shores.

The adult male has the crown, nape, and upper tail coverts grey; frontal band, lores, and ear coverts black; back chestnut; tail feathers black, all except the central pair with white bases; under parts rose buff.

The female has the upper parts brown, mantle rufous, with small narrow black crescentic bars on the feathers; under parts greyish white barred like the mantle. The young bird resembles the female, but is more barred. Length 7 in.; wing 3.7 in.

\section{THE WOODCHAT}

\section{Lanius pomeranus, Sparrman}

Single examples of this species have from time to time visited the southern and eastern counties of England during I03 


\section{Birds of Britain}

migration, and possibly they may have nested on one or two occasions. It is a common and abundant breeding species in Southern and Central Europe, from whence it migrates in winter to tropical Africa.

The forehead, lores, ear coverts, and sides of the neck and back are black; crown of the head chestnut; scapulars white; wings blackish, primaries with white bases, secondaries and coverts tipped with white; and upper tail coverts grey turning to whitish; tail feathers black tipped with white; under parts whitish. The female is duller and tinged with rufous on the upper parts. Length $7 \cdot 1$ in.; wing 3.8 in.

\section{THE MASKED SHRIKE}

\section{Lanius nubicus, Licht.}

This is a south-eastern species, one example of which was shot in Kent in July 1905.

It is a rather smaller bird than any of our other Shrikes. The upper parts are chiefly black; scapulars, speculum, and a band across the forehead white. Chin, throat, and under tail coverts white; flanks and breast ferruginous. Length 6.8 in.; wing 3.5 in.

\section{THE WAXWING}

\section{Ampelis garrulus, Linnæus}

Breeding as far north as the limit of tree growth will allow, the Waxwing is only known in these islands as an IO4 

WAXWING

Ampelis garrulus

Adult (left). Young (right) 


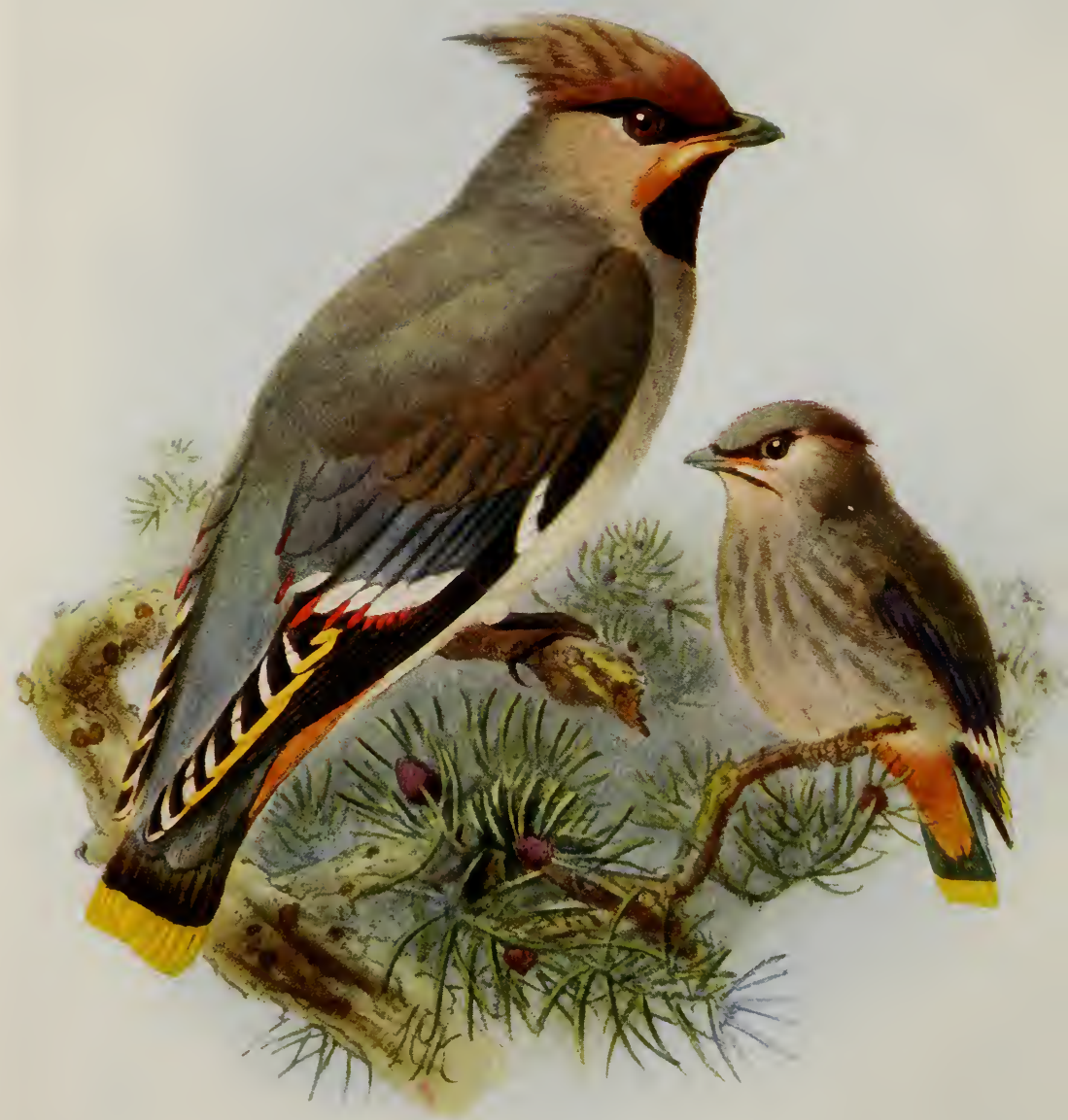





\section{The Waxwing}

irregular winter visitor. It migrates yearly to South-east France, Italy, and Turkey, and only under stress of weather do its migrations extend westwards, so as to include our islands. Its food consists chiefly of berries, though insects also form no insignificant part of its diet. When in these islands it will usually be found in plantations. It is a short thick-set bird, having a steady and rapid flight when on the wing. The general colour is greyish brown, and it has a flat and backwardly-directed crest that can be erected at will. The accompanying plate gives so good an idea of this bird, which has no affinities with any other species, that further description is unnecessary. The sexes are alike, but in the males the vermilion waxtips of the quill and tail feathers, to which it owes its popular name, are larger and more numerous.

In fully adult birds the yellow line of the outer vein of the primaries is continued on the inner vein, forming an arrow-shaped marking. Length 7.5 in.; wing 4.5 in.

\section{THE SPOTTED FLYCATCHER}

\section{Muscicapa grisola, Linnæus}

Dull in colour and lacking in vocal ability, this bird makes up for these deficiencies by his tameness and fascinating ways. It does not reach this country till early in May, while in backward seasons it is the end of that month before the main bulk of them have arrived at their summer quarters. It is common throughout these islands, nesting 


\section{Birds of Britain}

in gardens and woods, and feeds entirely on small insects, which are invariably captured on the wing. The nest, which is placed against a tree, in ivy near a wall, or frequently on the beam in a verandah or outhouse, is composed entirely of moss loosely felted together with cobwebs and lichens, and is lined with horsehair and a few feathers. The eggs are bluish, mottled and spotted with rusty red spots. From its quiet ways and unobtrusive plumage they often escape observation, even in the vicinity of the nest, on which the female sits very closely. The cock, however, may often be seen on his favourite perch, generally a dead bough, or some wire railings, from which he darts down constantly to seize some unfortunate insect that has attracted his attention, after which he immediately returns to his perch to wait for more. When the young are hatched his time is fully occupied in catering for their wants, and we may miss him, or only see him for shorter periods, as it becomes increasingly necessary for him to keep on the move and find his food instead of waiting until the unsuspecting prey comes to him.

In July and August, however, when family cares are over, we shall see a good deal of this species; both old and young chasing insects from various exposed perches, and announcing the successful capture by a telling snap of the bill. Towards the end of August, long before lack of food or storms toll the knell of departing summer, they start on their long journey to the south; we may not have taken much notice of them while they were with us, but their departure leaves a gap, and we then realise the part they played in the picture of a summer's garden. 

SPOTTED FLYCATCHER

Muscicapa grisola

Adult (right). Young (left) 


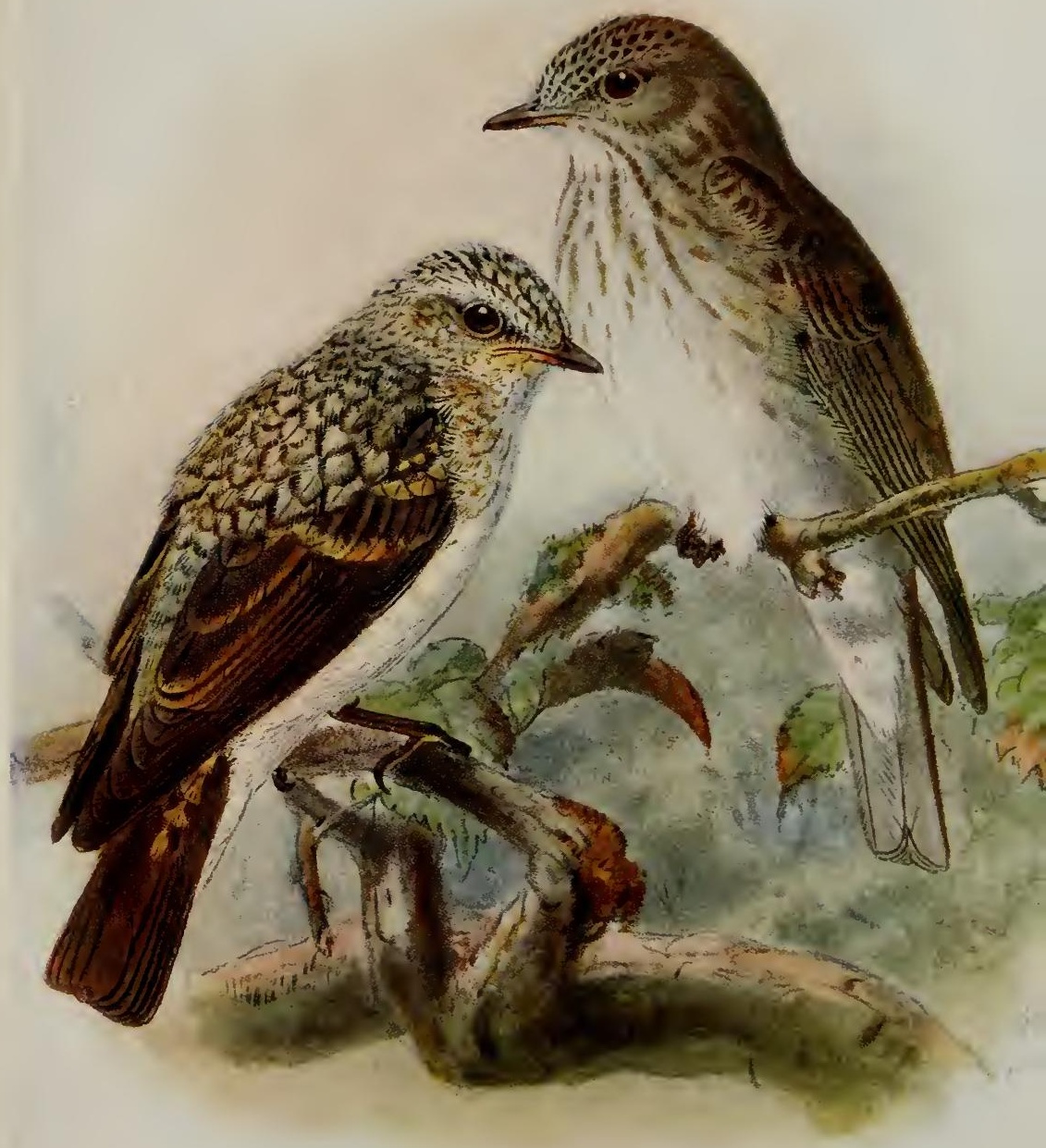





\section{The Spotted Flycatcher}

The upper parts are tan brown, with dark streaks on the crown, and pale margins to the wing coverts. Under parts whitish, streaked on the throat, breast, and flanks with brown. The sexes are alike in plumage. The young are similar in colour to the parents, but spotted with buff. Length 5.8 in.; wing 3.3 in.

\section{THE PIED FLYCATCHER}

\section{Muscicapa atricapilla, Linnæus}

Similar in habits but different in appearance, the Pied Flycatcher is much rarer and more local than the preceding species. Its breeding haunts are chiefly in the west, in Wales, Lancashire, Westmoreland, and Cumberland, though it has occasionally bred in other counties. As a migrant, however, it occurs regularly in the south and east, and, though not very numerous, a goodly number pass through the country, entering by the south coast and leaving again in the east from Norfolk northwards. A return migration takes place in August and September.

During these migrations it may, of course, be found in various kinds of country, but its breeding haunts are restricted to well-wooded spots, gardens, orchards, and the outskirts of woods.

The song is more elaborate than that of the Spotted Flycatcher, but it is by no means a great effort, and may be syllabled " tzit tzit tze trui trui trui !' several times repeated. The nest is always placed in some hole, usually in a tree, 


\section{Birds of Britain}

though exceptionally in the crevice of a wall; it is composed of bents and moss, and lined with feathers and hair. The eggs, sometimes numbering as many as nine, are of a uniform pale blue. Insects form its chief diet, but it is not so exclusive an insect-feeder as the preceding species, nor does it seize so much of its food on the wing, but frequently drops from its perch to pick a spider or other creeping thing from the ground.

In spring the male is black, with a white forehead and white outer margins to the secondaries. The under parts are white. The female has the upper parts olive brown, and those parts which are white in the male, rather buffish in tint. The young bird is spotted, but after the first moult it resembles the female, except that the wing patches in the male are more distinct. The young male assumes his full plumage at his first spring moult. Length 5 in. ; wing $3 \cdot 1$ in.

\section{THE RED-BREASTED FLYCATCHER}

\section{Muscicapa parva, Bechstein}

This species is of irregular and local distribution in Eastern Europe as far west as certain portions of Germany and South-east France, and it is only a few stragglers, driven out of their course by adverse weather or carried along by a rush of other migrants, that reach our coast.

In size it resembles our common species of Flycatcher, but differs in coloration. The adult males are of a uniform greyish brown above, with ashy grey cheeks and with the I 08 


\section{The Red-breasted Flycatcher}

chin and throat reddish orange. The females and young lack the ash grey on the head, and the reddish orange of the chin and breast is very much paler. Young males do not acquire the red breast for two or three years. The four outer pairs of tail feathers have conspicuous white bases. Length $5 \cdot 1 \mathrm{in}$; wing $2 \cdot 8 \mathrm{in}$.

\section{THE SWALLOW}

\section{Hirundo rustica, Linnæus}

Perhaps one of the greatest mysteries surrounding bird life, and awaking, even in the most unthinking, some sense of wonder, is the way in which some of the smallest and most delicate of birds cross enormous stretches of land and water twice a year. This mystery of migration has been especially typified in many countries and from olden times in the Swallow. Essentially a bird of the air, choosing the houses of man for nesting-places, and extremely abundant throughout our islands, he cannot fail to force himself on our attention and to become so associated in our minds with summer days that his first appearance in spring is eagerly looked for. As soon as the March winds have died down the first few stragglers make their appearance, and the early October gales are well over before the last has left.

During the whole of April they continue to arrive and disperse through the country, and by the beginning of May we shall find them revisiting the same chimney or eave where their brood was hatched in the previous year. They have but a feeble love-song, merely a rapid twittering, which 


\section{Birds of Britain}

is especially indulged in during the early hours of dawn, while waiting for the sun to call to life the flies and gnats on which they breakfast. Choosing a beam in a barn or outhouse, or a projecting brick in some old chimney as support, they build a neat cup-shaped nest of mud strengthened with straw to bind it together, and line it with bents, dry grass, and feathers. The eggs, generally six in number, are of a white ground colour dotted or blotched with reddish brown. The duties of incubation devolve on the hen, who is frequently fed by her mate, but soon after the young are hatched and she is free once more to seek her own food, both parents take their share in the duties of housekeeping.

This bird, eminently adapted for flight, with long pointed wings and short feeble legs, is hardly ever still. Round and round he circles, sometimes high, sometimes low, wherever food is most abundant, only perching for a few moments on some bare twig or telegraph wire to warble his twittering little song, and then once again to glide with graceful ease through the pathless air. Two families are generally brought to maturity, but he is in no hurry to leave his home and so he stays on well into the autumn.

Previous to his departure, however, we will see them collecting in large flocks at certain places, and for once they seem eager to economise their strength, spending much of the day sitting and resting. This goes on for a few days and then suddenly they all disappear, and we shall see them no more till next spring. Where have they gone, and how ? By what instinct will they find their way over hundreds of miles of sea, perhaps, for the first time, and yet again in due season return to their birthplace? By what power will 


\section{The Swallow}

they be able to undertake so long a journey and not fall exhausted on the way? Such are some of the questions that force themselves upon us, and our inability to answer them helps to keep alive that spirit of wonder and reverence for the powers of nature that is too apt to be overlooked in this matter-of-fact twentieth century.

Its colour above is of a deep metallic blue; forehead and throat dark chestnut; pectoral band blue, rest of under parts buffish pink, somewhat variable in tint. Tail forked, the outermost pair much longer than the rest, and all except the central pair with white patches on the inner webs. In the female the outer tail feathers are shorter and the chestnut less intense. The young are duller, and the chestnut on the throat is very pale. Length 7.5 in.; wing 4.9 in.

\section{RED-RUMPED SWALLOW}

Hirundo rufula, Temminck.

This species is found in Southern Europe west of Italy through Asia Minor to Persia and Afghanistan. An adult male was picked up dead on Fair Isle near the Shetlands early in June 1906.

It may easily be recognised from our own Swallow in having the tail black; rump, nape and sides of neck, rusty red; and the under parts rufous finely streaked with black. Length 7 in.; wing $4 \cdot 8$ in. 


\section{Birds of Britain}

\section{THE HOUSE-MARTIN}

\section{Chelidon urbica (Linnæus)}

More local and less abundant than the preceding species, from which it may always be distinguished by its white rump and shorter tail, the House-Martin is nevertheless sufficiently common to be familiar to every one.

In habits, except for its method of nest-building, it closely resembles the Swallow. It arrives about a week later, and stragglers may sometimes be seen even as late as November; long after the bulk of their comrades have departed. These stragglers are either family parties that have delayed their departure till the young were ready to fly, or more often inhabitants of the far north passing through on their long journey to the tropics.

Nest-building is not commenced till the middle of May, and by this time many of last year's nests, which they would fain repair, are tenanted by that abominable pestthe Sparrow. The nest is built entirely of mud, plastered bit by bit against the side of some house which has overhanging eaves. No straw is used to bind it together, but it is gradually built up to join the eaves till only a small hole is left as a doorway. The lining is composed of fine grass and many feathers, and the eggs, which rarely exceed four in number, are pure white. At least two broods are reared in the season, and then as the weather gets colder they gradually collect near rivers, where their food, in the shape of flies and gnats, is more abundant, till finally, after 




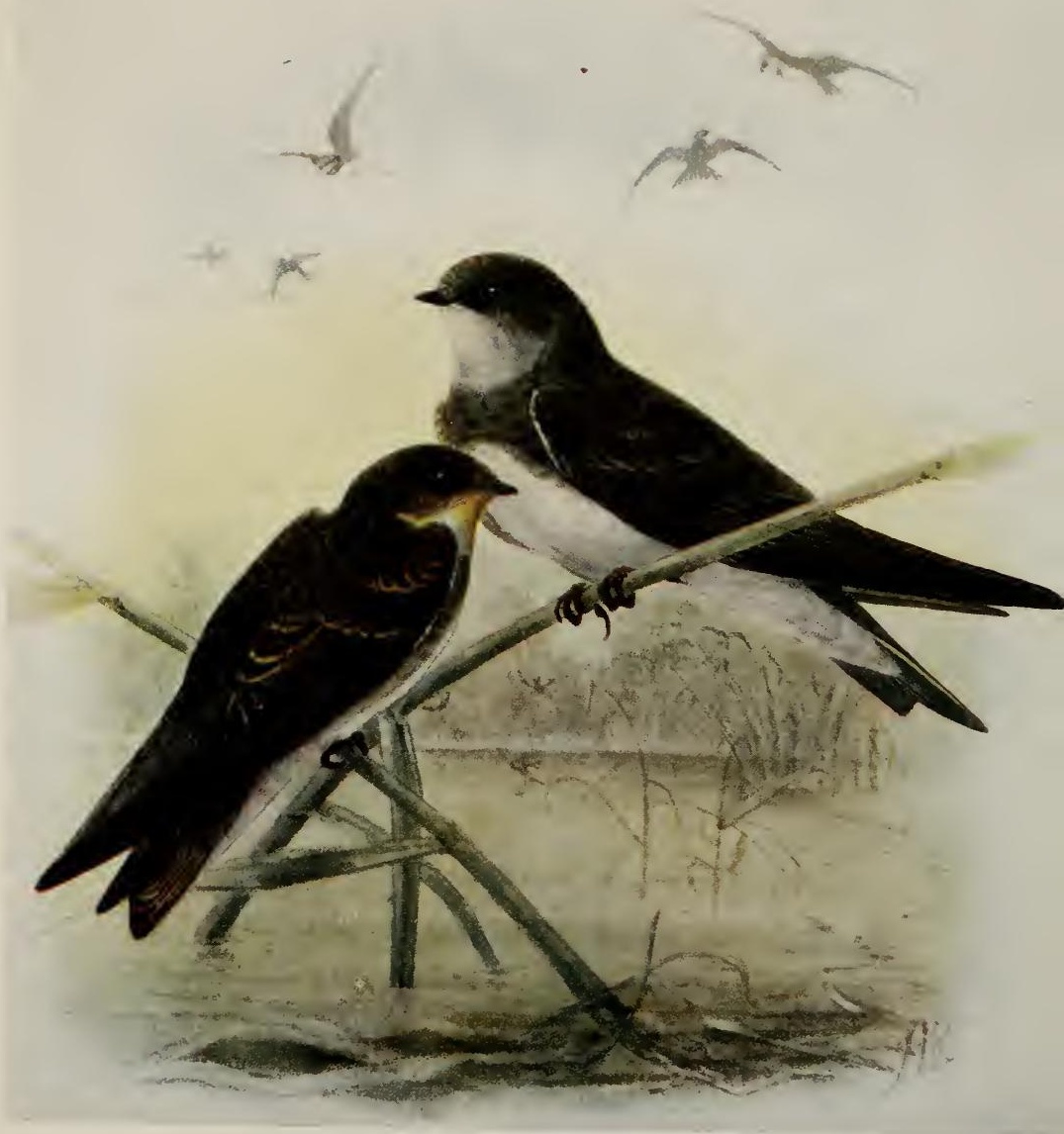





\section{The House-Martin}

assembling like the Swallows in large flocks, they suddenly take their departure.

The whole of the upper parts, except the rump, which is white, are glossy blue-black; the under parts, including the feathers on the feet, white. The tail is very slightly forked. The sexes are alike in plumage. The young resemble their parents, but lack the gloss and are consequently brownish. They may also be recognised by having white tips to the inner secondaries. Length 5.3 in.; wing 4.25 in.

\section{THE SAND-MARTIN}

Cotile riparia (Linnæus)

This hardy little wanderer, the smallest and dullest of the Swallow tribe, braves our climate ere the March winds have ceased. At first he is generally found in the neighbourhood of water, but he gradually spreads over the country and eventually assembles in the sand-pits or gravel banks, where he makes his home. Though not attaching himself to the dwellings of man, he is a sociable little bird and breeds in colonies, which are in some places very large. They nest in tunnels which they excavate for themselves in the perpendicular face of a sand-pit. These tunnels are straight and narrow with a slightly enlarged chamber at the end. Their length varies from eighteen inches to three feet, and the different passages occasionally meet and may be used in common by two pairs. A slight lining of bents and feathers are added, and the eggs, five in number, are 


\section{Birds of Britain}

pure white and somewhat pear-shaped. When the breeding season is over they scatter through the country, keeping largely to the courses of large rivers, and by the end of September have almost all departed to other climes.

The sexes are alike and have the upper parts brown. The under parts are white, with the exception of a brown pectoral band. There is a small tuft of buff-coloured feathers above the hind toe. In the young the feathers of the back have pale margins. Length $4.8 \mathrm{in}$.; wing $4 \mathrm{in}$.

\section{THE GREENFINCH}

\section{Ligurinus chloris (Linnæus)}

Were it not so common, occurring abundantly throughout these islands, this bird would be appreciated as one of our prettiest songsters and by no means unattractive in plumage.

The winter is spent in company with other Finches and Buntings in the fields or stackyards, where it feeds on the grain and other seeds, and we must confess that it performs its share in despoiling the farmer of his hard-earned produce, paying at the same time a sort of compensation in the destruction of numerous weeds. It is resident, and towards the middle of April constructs a somewhat untidy nest of twigs, rootlets, and moss, lined with grass, hair, and feathers, usually placed at a moderate height in a hedge, against the bole of a tree, or more rarely among ivy against a wall. The eggs, six in number, are large for the size of 


\section{GREENFINCH}

Ligurinus chloris

Male (below). Female (above) 


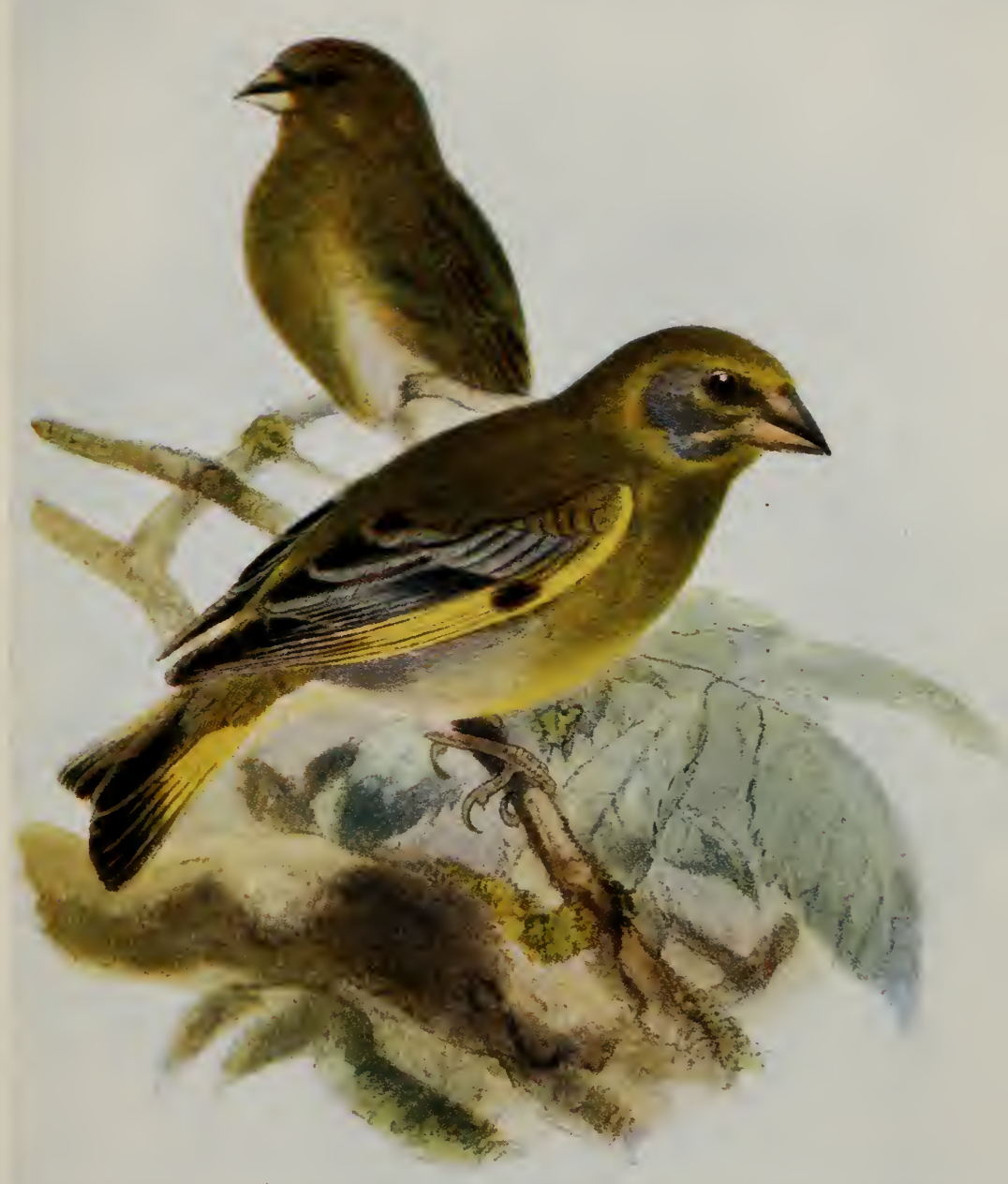





\section{The Greenfinch}

the bird and very pale blue, spotted, especially towards the larger end, with pale rust-red spots. During the summer large numbers of grubs and caterpillars are consumed in addition to the usual seeds; the young are fed by regurgitation. The call-note is a long drawn-out "tsweer," and is uttered with monotonous frequency during the spring and summer months, but it has also a very pretty warbling song full of little trills and modulations which it utters when sitting on a branch or when courting its mate with drooping wings and outspread tail, and every feather on its body quivering with excitement and passion.

The male has the upper parts olive green, rather yellower on the rump and forehead. There is a golden-yellow eyestripe. The wing feathers are dark brown with bright yellow outer margins. Tail feathers, except the central pair, which are black, yellow at their base with black tips. Under parts greenish yellow, rather darker on the flanks. The females are much duller than the males and very brown on the upper parts in winter. The young are brownish yellow, streaked on the breast with darker brown. The males do not acquire their full plumage till their second year. Length 6 in.; wing 3.5 in. ; but some examples are much smaller.

\section{THE HAWFINCH}

\section{Coccothraustes vulgaris, Pallas}

This fine and handsome species, whose appearance is only marred by the excessive size of its beak, is by no 


\section{Birds of Britain}

means so rare as it is usually considered. It is found locally in most wooded districts of England, but becomes scarcer in the north and is decidedly rare in Wales. To Scotland and Ireland it is, however, only a rare and occasional wanderer. Extremely shy, avoiding the haunts of man, and keeping to the tops of high trees, its presence is very difficult to detect, and the call-note, which is a weak and high-pitched "sit," would not attract attention unless specially listened for.

The nest, which is built fairly high up near the top of a tall hedge or in a tree, a tall hawthorn being an especial favourite, is composed of fine twigs lined with rootlets, and much resembles that of a Bullfinch, except that the cup is considerably deeper. The eggs are extremely handsome, being of a bluish green, boldly blotched and streaked with black or olive grey. This bird has one weakness which leads to his destruction, namely, a great fondness for green peas, in search of which, forgetting his usual caution, he will leave his haunts to forage in the nearest garden, where as often as not he pays for his rashness with his life.

His food consists almost entirely of seeds and berries, insects forming a very small portion of his diet. In winter he collects in small family parties and wanders about from wood to wood but seldom strays very far from home.

The male has the back brown, becoming lighter on the rump; the upper wing coverts blackish; median coverts whitish. Wing feathers black with white patches on the inner webs and steel-blue tips, the inner primaries being curiously expanded at their tips. Tail feathers with black bases and white tips. The head is yellowish brown, paler 


\section{The Hawfinch}

on the forehead; nape grey; lores, chin, and a narrow stripe at the base of the bill black. Under parts brown. Bill deep lead colour in summer, horn coloured with black tips in winter. The female is much duller. The young have the head yellowish; mantle mottled brown; under parts white spotted and barred with dull brown. Length 7 in.; wing 4 in.

\section{THE GOLDFINCH}

\section{Carduelis elegans, Stephens}

A cold autumn day, the clouds hang lowering in the sky; on one side flows the river, sullen, dark, and swollen by the recent rains, on the other stretch wild and bare meadows whose flat level is broken by clumps of nettles, thistles, and other coarse plants distasteful to cattle. One thing alone breaks the geueral dreariness-it is a flock of Goldfinches, who, as they hang in strange attitudes on the thistle heads, show the bright yellow of their wings, making it appear as though some plant, forgetful of the season, was about to burst into flower. As we approach to get a closer view, first one and then another will rise and in undulating flight move on to another clump and call his companions to a fresh hunting-ground with his little "ti-whit!" His bright colours and the ease with which he adapts himself to cage life have led to a great diminution in his numbers, in addition to which the higher and more scientific methods of farming have sadly restricted his feeding-grounds. Legislation, however, has stepped in, so that, although still a comparatively 


\section{Birds of Britain}

local bird, he is steadily increasing in numbers, and we have reason to hope that he may long remain a welcome inhabitant of our fields. The whole winter is spent roaming about on waste lands feeding on seeds or berries, and destroying countless weeds which would otherwise overrun the land. In spring the flocks break up, and our friend returns to the orchard or garden where he nested the previous year. He constructs an open cup-shaped nest of moss, bents, and small twigs fairly high up in some tree, often covering the outside with lichen to assimilate better with its surroundings. The lining consists chiefly of hair and thistle-down, and the eggs are blue, spotted and streaked, especially at their larger ends, with reddish brown. The young are fed at first by the regurgitation of half-digested food from the crops of their parents, and at this time of year a large number of insects are consumed. Two broods are often raised during the season, and then the family party wanders out into the open fields to seek their food, returning at night to the gardens, till they get gradually farther and farther from home and no longer visit their summer haunt till the following spring.

This bird is so well and generally known that no detailed description is necessary. The female may be distinguished by her more slender bill and brownish shoulders, (lesser wing coverts). In the adult male the shoulders are jet black, but young males sometimes show traces of brown.

The young, known as "grey pates," are greyish brown on the upper parts and lack the characteristic markings on the head. The true Russian Goldfinches are rather larger in size and have a nearly white rump. The true "Siberian GoldI 8 

GOLDFINCH

Carduelis elegans

Male (left). Fgmale (centre). Young (right) 


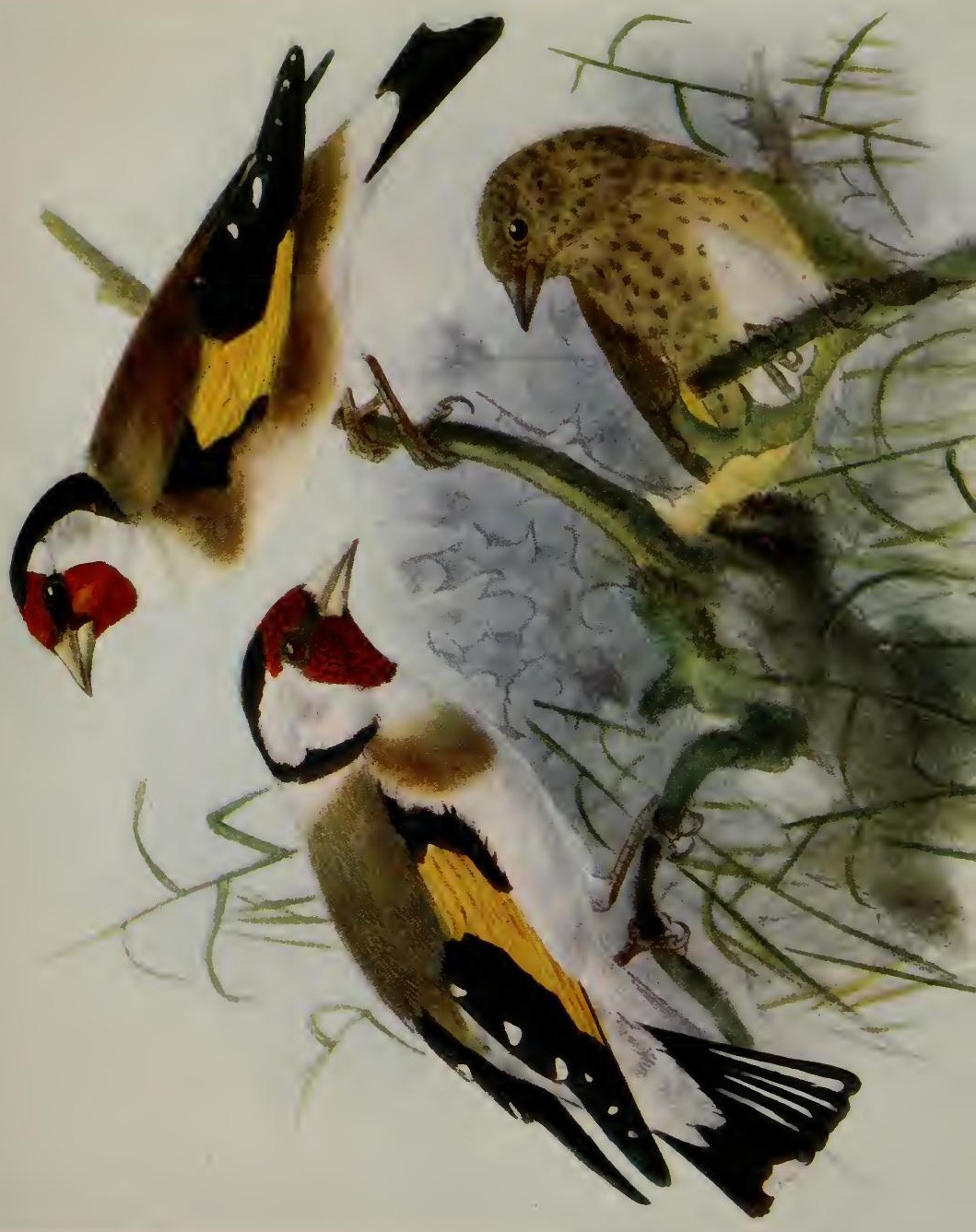




\section{Birds of Britain}

increased so as to be beyond all limits? Wherever man settles, there, sooner or later, will he make his appearance, sitting on the roof or in the shrubbery, and uttering, especially in the mornings, his monotonous and impertinent chirp. In spring he pulls up the crocuses, later he turns his attention to young and succulent plants just forcing their way above the ground, or if a new-sown lawn be the object of one's solicitude he will make it his business to see that the hoped-for grass-plot remains a barren tableland. As summer comes on, the drain-pipes are blocked by his untidy nest-a mere heap of straw and hay warmly lined with feathers. If a tree or the ivy against the house be chosen for a site, the nest is better made, and is in fact a substantial dome-built structure with the entrance at the side, but its position is readily betrayed by long untidy bits of straw left trailing outside. The eggs are five or six in number and bluish white spotted and blotched with ash brown. By the end of summer he will have reared two broods of five or six youngsters each, and for a time our gardens are allowed a brief respite, while old and young gather in immense flocks in the harvest-fields, and then following the grain they spend some weeks round the freshly-made stacks in the farm-yard. As winter comes on they return once more to towns and gardens, where, by assuming a cold and starved appearance, they beg and frequently receive our charity, till the blooming of the spring flowers once more enables them to start their round of theft and damage. So much for their relations towards man, and it is to be feared that their relations towards other birds have also no redeeming point, for they are so quarrelsome that none of the more 


\section{The House-Sparrow}

delicate and beautiful of our birds will live near them, and the House-Martin clinging to his home with pathetic persistence is driven away again and again by this impudent marauder.

Is there, however, not one good word to be said for him? $\mathrm{He}$ is at least by no means bad-looking - the chestnut of his back, his slate-blue head, black and white cheeks, and black throat all tend to add a touch of life and beauty to our gardens which they would otherwise lack; and then in summer he destroys countless noxious insects while feeding his brood, and in towns how companionable he is, hopping about our windowsills or on the roadway, evading the passing traffic with a knowledge born of long practice-surely these at least are compensations that entitle him to some regard.

These arguments, however, all fail. Remove the Sparrow and his place will soon be taken by other birds more beautiful, who will destroy insects, not merely when they have their broods, but throughout the year, and they will soon populate our towns and gardens to as great an extent as the present pest. Remove him? Yes! but how? There's the rub. Man in the face of the Sparrow is, at present, powerless. True, the bitter war he deserves is not waged on him in this country, but abroad, in Australia and America, relentless persecution is carried on, and though his numbers may be kept in check he is still able to yearly inflict a loss and damage that can only be measured in millions of pounds.

At the same time man is largely to blame for this increase. By careful farming, woods and thickets which should shelter many other species of birds are cut down or reduced, and thereby a similar reduction of their inhabitants 


\section{Birds of Britain}

is created ; grain, the Sparrow's favourite food, is cultivated in enormous quantities, and birds of prey who might tend to keep the Sparrow within reasonable limits are ruthlessly destroyed. Under these circumstances, then, is it to be wondered at that the Sparrow, having a large number of his competitors for food reduced, his enemies swept away, and unlimited food supplied, should increase beyond all reasonable bounds, especially if added to this we remember that he is exceedingly crafty and cunning, soon recognising and avoiding traps and becoming very difficult to approach in places where he is frequently shot at. $\mathrm{He}$ is at the same time adaptable and able to attach himself to the dwellings of man, who supplies him (albeit involuntarily) with a plethora of food; under such conditions his increase is only the result of one of Nature's first laws, the "survival of the fittest."

This species is too well known to need a description. The female lacks the black on the throat and the grey and chestnut on the crown, and her colours generally are much duller. The young approach the female in general coloration, but young males often show traces of black on the throat. Length 6 in.; wing 3 in.

\section{TREE-SPARROW}

\section{Passer montanus (Linnæus)}

Although so closely allied to the preceding pest, the Tree-Sparrow is a bird of very different temperament and I 24 

TREE-SPARROW.

Passer montanus 


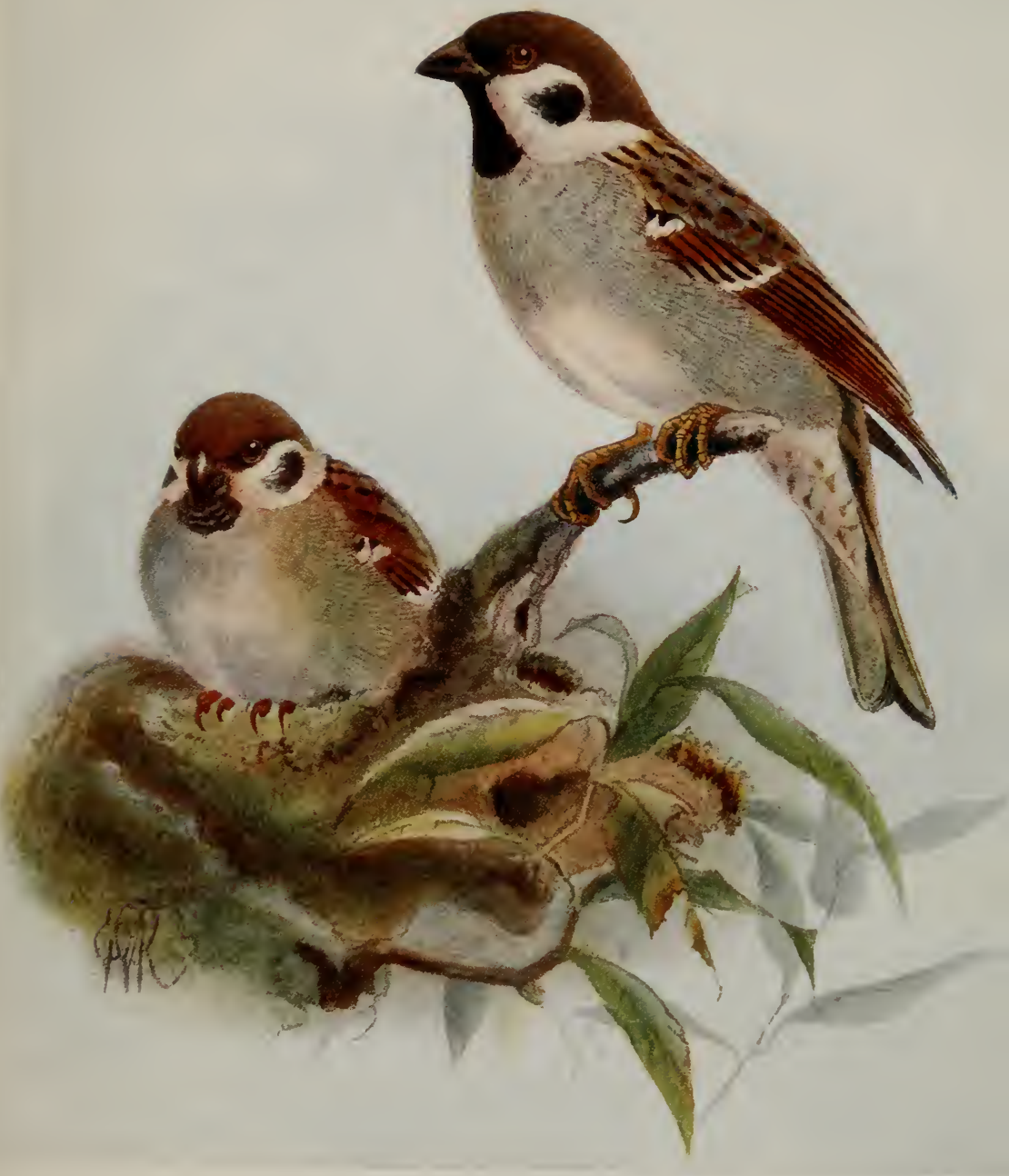





\section{Tree-Sparrow}

habits, and worthy to be numbered among our bird friends. Many spend the winter with us, but it is partially migratory, and their numbers are increased each spring by arrivals from abroad. It is a rather local and scarce bird, but even in places where they are common they are so shy that they are hardly ever seen, and are considered in consequence much rarer than really is the case. It shuns the habitations of man, whether because of the overpowering insolence of its larger relative or not is a debatable point, but the fact remains that if we want to see it we must find some secluded and undisturbed spot. Holes in pollard willows or in some hedgerow tree are generally chosen for a nesting-site, inside which a substantial nest of grass abundantly lined with feathers is formed. Five eggs form the clutch. These are greyish in ground colour, delicately but thickly mottled with brown, and it is an almost invariable rule that one egg of a clutch should be conspicuously lighter than the others. Little is known of the habits of this bird; its food consists chiefly of seeds and berries, but in summer insects form a large part of its diet and the young are almost entirely reared on them. Its notes and song very closely resemble those of its commoner relative but are slightly more musical and less harsh.

The adult has the crown and nape dark chestnut, rest of upper parts chestnut with darker centres to the feathers; upper and lower wing coverts tipped with white and forming two distinct bands. Cheeks white with a triangular black patch in the centre. Chin and throat black; rest of under parts greyish white passing to brown on the flanks. Length 5.6 in. ; wing 2.75 in. The sexes are alike in plumage. The young are similar to their parents but duller. 


\section{Birds of Britain}

It is a scarce and local species but widely distributed, and doubtless from its retiring habits and resemblance to the House-Sparrow it is often overlooked.

\section{THE CHAFFINCH}

\section{Fringilla cœlebs, Linnæus}

"Pink, pink!" Who among us does not know the Chaffinch with his bright "pink, pink," and perky walk, as he goes down the garden path in front of us, or flies into the nearest shelter. showing off the white bars on his wings as he does so. No matter how severe the winter or how hot the summer, he is always with us, a constant visitor to our gardens, and when. we go into the woods and fields we shall still find him equally at home. Early in February he begins his song, which consists merely of a short run down the scale ending up in the syllables "de-wi." Pairing takes place early in the season, but some weeks elapse before he thinks of nesting, well knowing that the insects so necessary for his young are not yet born. At the end of April his mate will begin to build the nest, while her lord and master sits quietly by, encouraging her with his song but not deigning to soil his beak or feet with honest toil. The site chosen is very variable; the fork of some giant tree or against the trunk of a hedgerow elm supported by a lateral shoot are the places most frequently used, but it is often situated in a hedge, and sometimes in the ivy against a wall. The nest itself is a beautiful mass of moss, grass, and wool carefully felted 




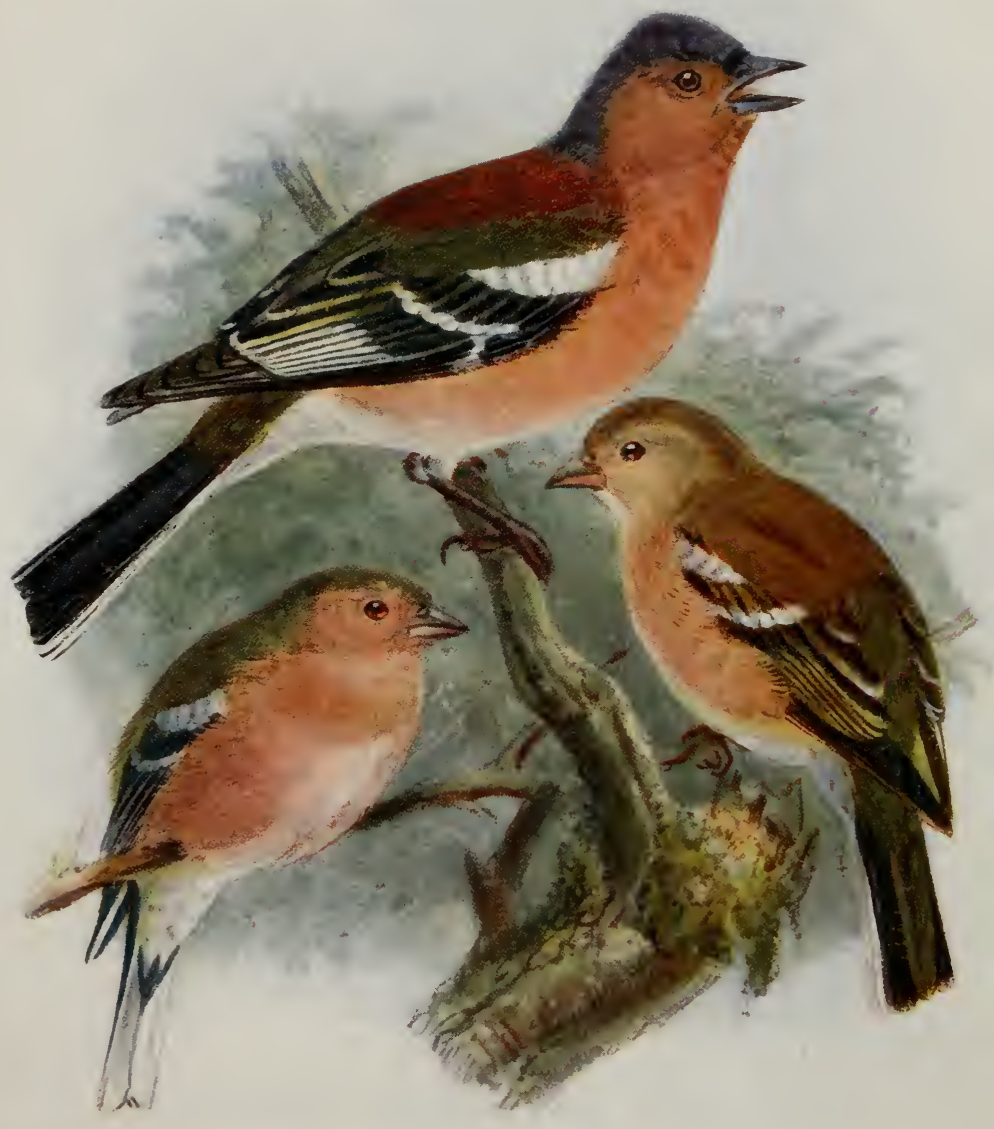





\section{The Chaffinch}

together with cobwebs and thickly lined with hair, lichens being often added on the outside to make it assimilate better with the surroundings. The eggrs, generally four in number, are greenish blue, spotted and clouded with deep reddish brown, but occasionally the markings are entirely absent.

During incubation the male waits on his hen with great care, bringing her all the titbits and delicacies in the way of insects which he can find, and both sexes are assiduous in their attentions to their young.

After the duties of housekeeping are over, the rest of the year is spent in the woods, hedgerows, and gardens, feeding promiscuously on insects, seeds, and berries. Towards the middle of October large flocks, in which sometimes one sex largely predominates, reach our shores from more northerly breeding haunts; most of these, moving southwards, feed largely on beech-mast in company with Bramblings and then pass on, but many remain to keep us company during the winter, till early in spring they return again to their breeding quarters.

The male has the crown and nape bluish grey; back reddish brown; rump greenish; upper wing coverts white; greater wing coverts black tipped with white and forming two conspicuous bars. Wing and tail feathers black, the former edged with yellowish white, and the two outermost pairs of the latter spotted with white; cheeks and under parts reddish brown. Bill horn coloured in winter, deep lead grey in summer. Legs dark brown. The female is of various shades of yellowish brown, but the white wing bars are conspicuous. The young at first resemble the female. Length 6 in. ; wing $3 \cdot 4$ in. 


\section{Birds of Britain}

\section{THE BRAMBLING}

\section{Fringilla montifringilla, Linnæus}

This bird, closely allied to the Chaffinch, is only a winter visitor to this country, visiting us in large numbers. every autumn, when it will usually be found feeding on the beech-mast. In years when the "mast" is plentiful these birds seem to be much more numerous than in other seasons, but this is probably due to the fact that, tempted by the abundance of food, they elect to pass the winter with us instead of moving on southwards. Frequenting the open field in company with other Finches, it feeds also largely on seeds and berries, though in summer it becomes, like the Chaffinch, chiefly insectivorous. Its breeding range extends across Europe and Asia, in the sub-Arctic birch forests, whence it migrates southwards through Central Europe, but seldom reaching the Mediterranean basin. In our islands it is commonest in the north and east, becoming scarce in the west and south-west. In Ireland it has only occurred at very irregular intervals. It commences the return journey in March or earlier, the actual time being largely dependent on the state of the weather, and by the first week in April the last stragglers have usually left us.

The male in summer has the head, nape, and upper parts blue black, with the exception of the rump, which is white. Upper wing coverts orange buff; greater wing coverts black tipped with white. Throat and breast orange; belly white; flanks spotted with black. Bill deep lead grey. In 


\section{The Brambling}

winter the black of the upper parts is largely concealed by broad buff margins to the feathers and the under parts are much duller. Bill yellow with a black tip. The female is dull brown on the back and a brownish white below. The young resemble the female. Length $6 \cdot 1$ in.; wing $3 \cdot 6$ in.

\section{THE SNOW-FINCH}

\section{Montifringilla nivalis, Linnæus}

A single example of this bird, which inhabits the high mountains of Central and Southern Europe, was observed consorting with Larks near Rye in Sussex in February 1905.

The head and neck are grey; upper parts brown with darker centres; wing coverts, secondaries, and the whole of the under parts white; tail feathers, except the central pair, which are brown, white tipped with black; chin black. Length 6.4 in.; wing 4.53 in.

\section{THE LINNET}

\section{Linota cannabina (Linnæus)}

A delightful little bird of sombre plumage is the Linnet, and as a cage-bird he has long been a prime favourite. In this country he is generally distributed and fairly common. Almost any kind of country suits him-hedges near open and cultivated land, furze-clad commons, or the wild hillside all afford him shelter and food. In habits he is gregarious and 


\section{Birds of Britain}

may be seen during the winter in small parties of from eight to ten flying from place to place, with cheery twittering, and if the weather be severe, especially when snow is on the ground, he collects in enormous flocks of several hundreds. Their food consists of seeds and berries, though insects are largely eaten during the summer months. The nest is placed in a furze bush or hedge at no great distance from the ground, and is a neat and compact structure of grass and bents bound together with a little moss and wool, and lined with hair, wool, and feathers. The six eggs are of a delicate pale blue blotched with moderately large reddishbrown spots. Two broods, at least, are reared in the season, and when the cares of housekeeping are completed they wander about at random until the following spring brings a return of more serious occupation. The song, although very pleasing, cannot be called great, and is a kind of continuous chuckling which is often delivered whilst on the wing. The flight is as a rule strong, rapid, and undulating, the flocks often travelling considerable distances to reach a favourite feeding-ground or when returning to roost in a well-sheltered plantation. During the courting season the male indulges also in a very pretty love flight; he rises some distance in the air and then slowly descends with rapid flutterings of his wings and out-spread tail, singing at the same time with all his might.

In autumn large numbers reach us from the Continent, and there is also a certain amount of emigration among our home-bred birds.

The upper parts in the male are brownish, greyer on the nape and more rufous on the mantle. Wing and tail 


$$
\begin{aligned}
& 1212 \\
& \text { sin }+x
\end{aligned}
$$

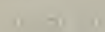


LINNET

Linota cannabina

Male (above). Female (below) 


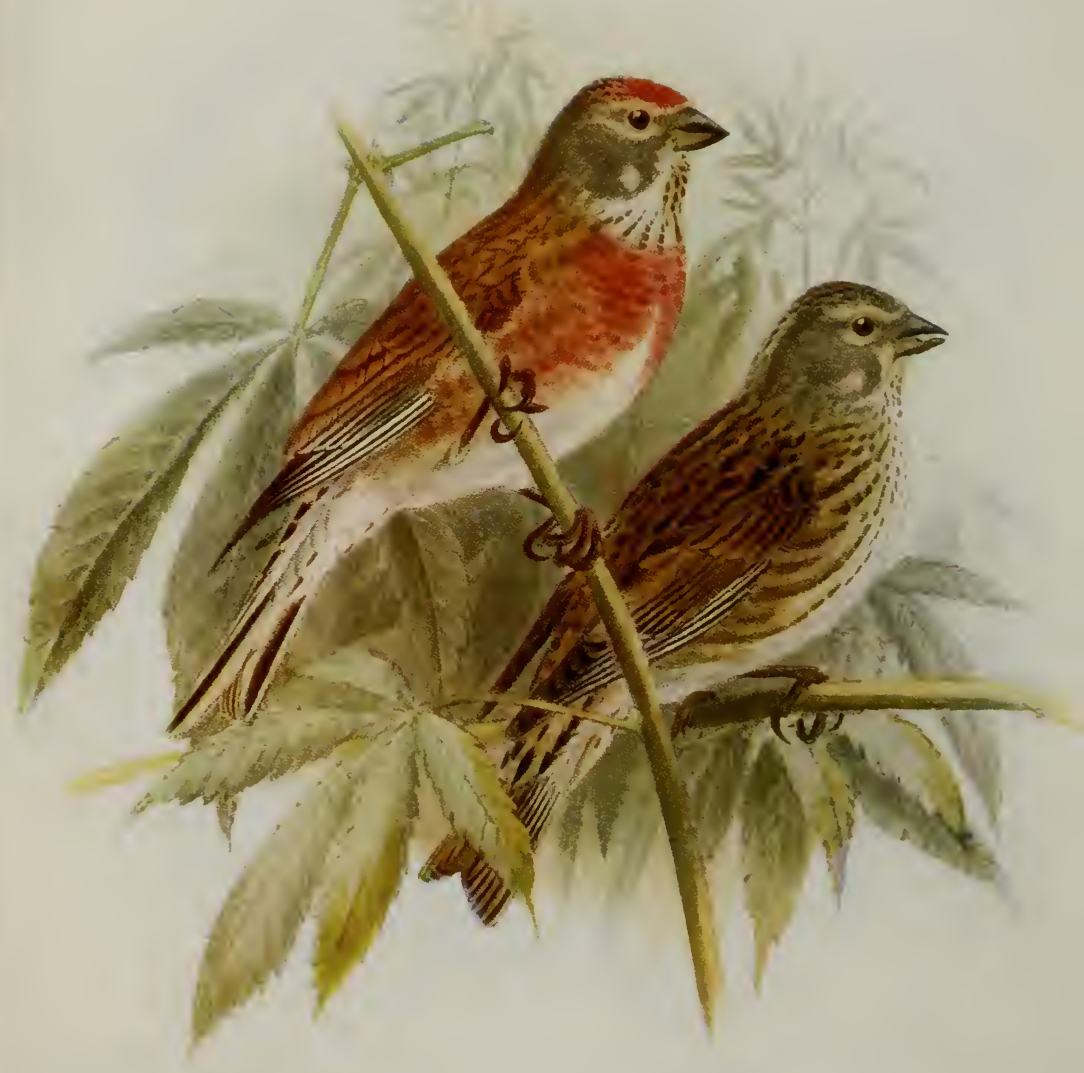





\section{The Linnet}

feathers black with white outer margins. Crown of the head and breast deep crimson; flanks brown; belly white. Length 5.5 in.; wing 3.15 in. In winter the red on the crown and breast is deep brown and the feathers of those parts have broad yellowish margins. The female resembles the male on the upper parts, but the mantle is duller and the white of the primaries is much less in extent. The under parts are yellowish brown streaked with dark brown, and the head is also streaked with brown.

The young resemble the female, but are paler.

\section{THE MEALY REDPOLL}

\section{Linota linaria (Linnæus)}

This species breeds in circumpolar regions far north above the limit of tree growth, wherever a few dwarf birch or willow afford it enough cover for nesting, and is only an irregular winter resident in our islands. It has been subdivided into various races by systematic writers, on differences which need not concern us here, but although the commonest form met with in these islands belongs, as we would naturally suppose, to the North European race, the Greenland form has also been noticed on several occasions. Wandering through the country in small parties and associating with our native Redpolls, this species frequents gardens, stack-yards, or still more frequently, the low scrub that may be found in many places along the coast. With us its food consists almost entirely of small seeds, but 


\section{Birds of Britain}

during the breeding season in the north it feeds largely on insects. Its stays with us are of short duration, for it rarely arrives before the first cold weather in November and leaves our shores again early in February to revisit as soon as possible its northern home.

It is very similar in general appearance to the following species, but is larger and paler, especially on the rump. Length 5.1 in. ; wing 2.9 in. The Greenland race is larger still, almost equalling the Linnet in size. There is still another form which has occurred in these islands and which may be recognised by its nearly white rump.

\section{THE LESSER REDPOLL}

\section{Linota rufescens (Vieillot)}

This species is a regular resident with us and may be found in most of our counties. As a breeding bird, however, it becomes scarcer in the south of England and local in Scotland, its chief haunts at that time of year being the north of England, Wales, and Ireland.

During the winter months it wanders about in large parties and its chuckling call-note may often be heard as they pass from one field to another. It nests chiefly in woods, the nest being placed against the trunk of some tree at a moderate height from the ground. The nest is an extremely neat structure of twigs and moss, beautifully formed and lined with vegetable down, wool, and feathers. The eggs, except in size, are much like those of the Linnet, but the ground colour is darker and the spots are smaller. In 

MEALY REDPOLL

Linota linaria

Female (above). Male (below) 


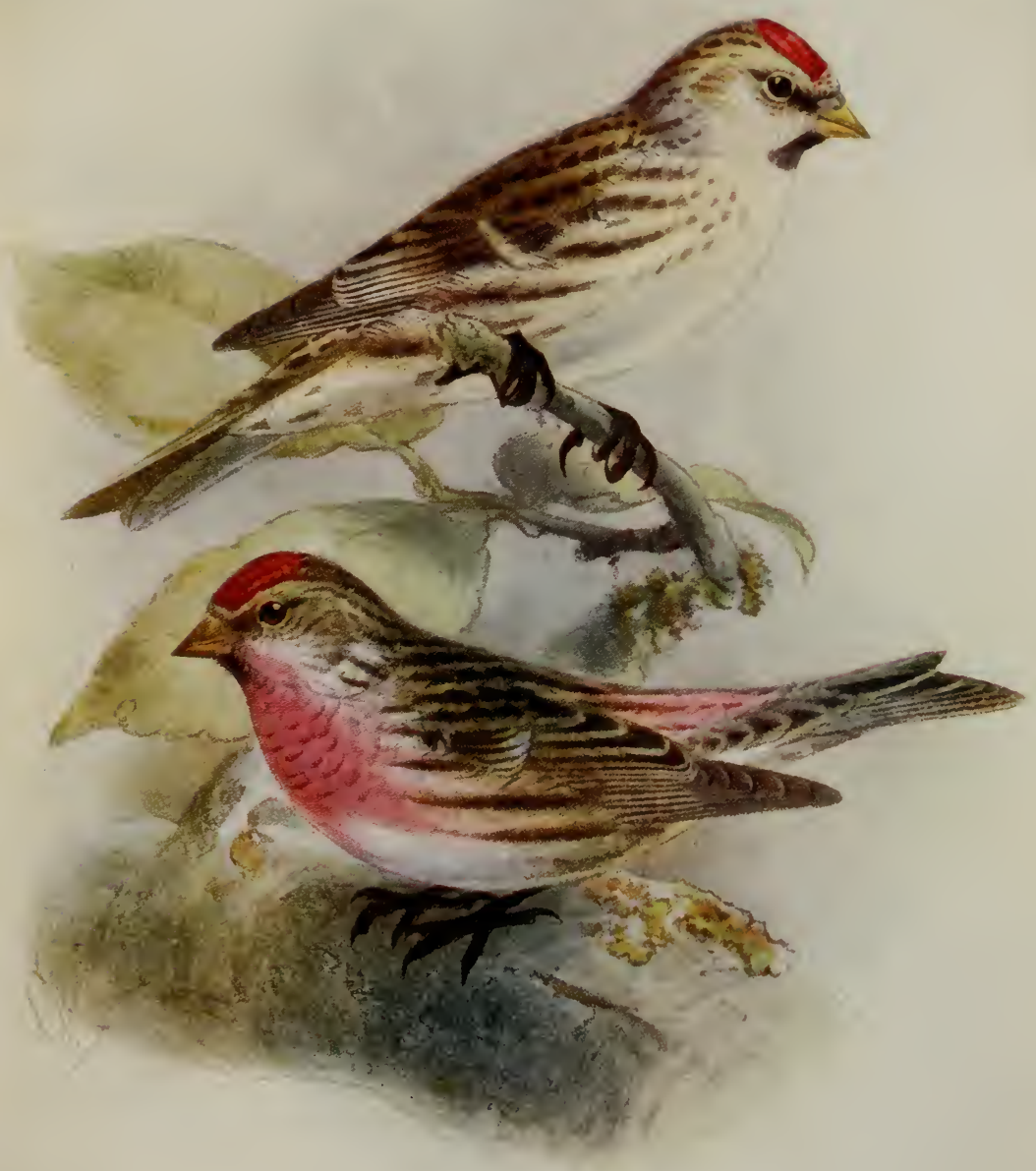





\section{The Lesser Redpoll}

summer the Lesser Redpoll feeds chiefly on insects, but seeds and berries are eaten at all seasons and especially in winter.

They may be found in all kinds of country, generally associating with other Finches and Buntings, but they are rather more partial to woods, gardens, and orchards. Their song bears a family resemblance to that of the Linnet, but is not so melodious or sweet. This bird is very tame and confiding, and may often be watched as it moves about in the trees of some orchard, examining them carefully for insects and reminding one in its actions of the Tits.

The male has the upper parts of a warm brown with darker streaks. Lores and throat black; the crown, rump, and breast are carmine; rest of the under parts whitish, becoming browner with dark streaks on the flanks. In autumn the red tints on the rump and breast are much obscured by the broader pale edgings to the feathers. The female is rather smaller than the male and lacks the red on the breast and rump. The breast is buff with dark stripes, and the rump similar in colour to the mantle but paler. The young resemble the hen but lack the red on the crown. Length 4.75 in.; wing 2.75 in.

In winter this species shows far more red on the breast than does the Mealy Redpoll at the same time of year.

\section{THE TWITE}

\section{Linota flavirostris (Linnæus)}

Inhabiting moorlands and breeding among the heather, this gregarious species may be found from the Midlands 


\section{Birds of Britain}

northwards. In England, however, it cannot be called common, but in parts of North Wales, Scotland, and Ireland it is abundant. It nests in colonies, the nests being placed on the ground or in a low bush; they are neatly made of rootlets, pieces of heather, and moss, lined with hair and wool.

The eggs, like those of the other Redpolls, are blue spotted with red. Two broods are reared in the season, and as soon as the first brood is fledged the whole colony will sometimes move off to an adjacent spot for the second brood, so that they may be found with young in the nest one week, and a few days later no sign of them or their young will be found at that spot. During the summer their food consists largely of insects, while seeds form their chief diet in winter. After the breeding season they leave the upper moorlands and wander south, a fair number reaching the south of England, especially in severe winters. It chiefly frequents the wild open country and marshes by the sea-shore, but in the more wooded localities it is rarely found and it seldom perches on trees. It has a pleasing little song and the callnote is a loud "twah-it," whence its English name of Twite.

General colour above dark brown with slightly paler edgings to each feather. Wing feathers blackish with white outer margins, as in the Linnet. Tail somewhat forked, the feathers being black with whitish inner margins to the three outer pairs. Under parts buffish white streaked with brown. In the male the lores, cheeks, throat, and rump are suffused with rose red, but the female shows no red whatever. The bill in both sexes is deep horncoloured in summer and yellowish in winter. The young resemble the female. Length 5 in.; wing 3 in. 


\section{The Bullfinch}

\section{THE BULLFINCH}

\section{Pyrrhula europæa, Vieillot}

Better known probably as a cage-bird than as a wild inhabitant of our woods and gardens, the Bullfinch is nevertheless by no means rare. It inhabits woods, coppices, and thick hedgerows, and is rather a skulking species, but may be recognised when on the wing by its white rump. The call-note is a rather plaintive "whee-ou," and it is easily attracted by imitating its call. Possibly it pairs for life, at least it is generally found in pairs, and even during the winter the male shows considerable affection for his mate, generally keeping close to her and frequently feeding her. The song is a feeble medley of soft flute-like notes, and is generally accompanied by a side to side motion of the tail and body. The nest is commenced in May and consists of a shallow platform of twigs placed three or four feet from the ground in a thick bush or hedge, and is lined with fine rootlets. The eggs, usually four or five in number, are greenish blue spotted and streaked round the larger end with black or pale purplish lilac. The young are fed by regurgitation, insects forming a large proportion of the parents' food during the summer.

When fledged young and old wander about for a time together, but the old birds soon forage on their own account and leave the young to look after themselves. Berries, especially those of the privet, are largely consumed in autumn, but all kinds of seeds form their diet during the winter months, and 


\section{Birds of Britain}

in spring they turn their attention to young buds, more especially those of fruit-trees. For this they may well be forgiven as they make ample compensation by destroying caterpillars innumerable during the summer months.

The male has the whole of the head a glossy blue-black, mantle brownish grey. Larger wing coverts black tipped with whitish to form a conspicuous bar. Primaries brown; secondaries and tail glossy black; rump white. The whole of the under parts bright brick-red turning to white on the vent. The female is duller and the under parts are of a uniform brown. The young resemble the hen but lack the black crown. Length 6 in.; wing $3 \cdot 25$ in.

This species is generally distributed throughout the wooded districts of England, Wales, and Ireland, but is rather more local in Scotland.

\section{THE SCARLET GROSBEAK}

\section{Pyrrhula erythina (Pallas)}

The Scarlet Grosbeak breeds from Northern Russia across Siberia to Kamchatka, and in winter it is chiefly found in the Oriental region. As a straggler on migration, however, it has visited many places in Europe to the west of Russia, and one or two examples have been obtained in this country.

The adult male has the greater part of its plumage rose red, browner on the mantle and flanks. Quills and tail dark brown with paler buffish margins. The female is olive I 36 



\section{BULLFINCH}

Pyrrhula europaca

Nale (right). Female (left) 


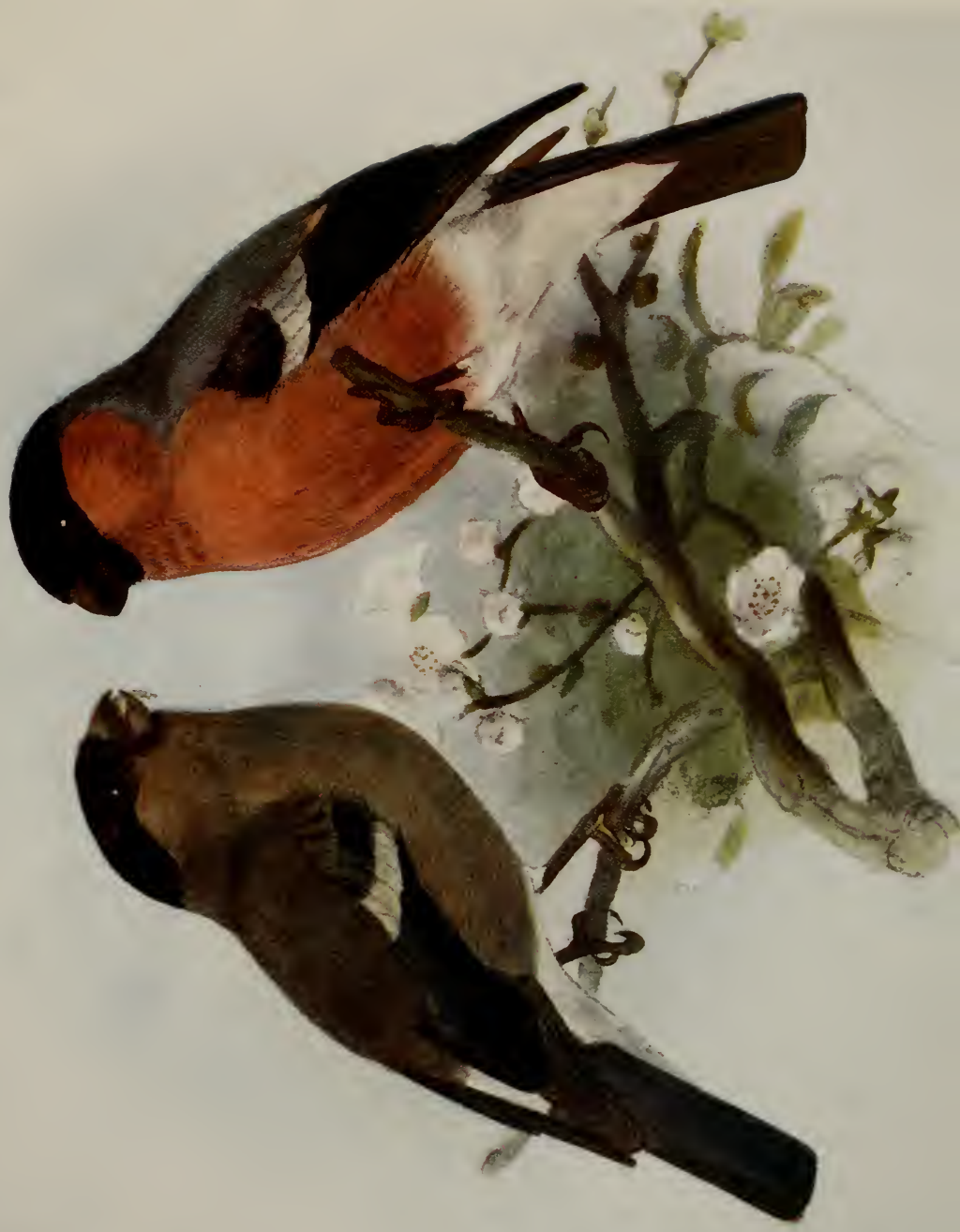





\section{The Scarlet Grosbeak}

brown with darker striations, the under parts dull white, buffish on the throat and breast, and striped with brown on the flanks. Length 5.5 in.; wing 3.25 in.

\section{THE PINE GROSBEAK}

\section{Pyrrhula enucleator (Linnæus)}

This species, as its name indicates, is an inhabitant of pine woods and makes its home in the vast conifer forests of Northern Europe and Siberia. Over the rest of Europe it is very scarce and is only known from occasional stragglers. In this country about forty different occurrences have been recorded, but it is probable that a large number of them had escaped from captivity.

The general colour of the male is a rich rose red all over, rather greyer on the flanks and belly. Wing coverts brown, each feather having a pinkish white tip. Quills and tail brown, secondaries margined with white. In the female the rose tint is replaced by a dull golden yellow. The young are greyish green and do not assume their full plumage before their second year. Length 8.25 in.; wing $4 \cdot 25$ in.

\section{THE CROSSBILL}

\section{Loxia curvirostra, Linnæus}

The Crossbill is by no means a common bird and very uncertain in its appearances. A fair number breed as 


\section{Birds of Britain}

early as March in the pine woods of Scotland, and during the rest of the year it wanders about in small parties. Feeding chiefly though not exclusively on the seeds of the pine, which the peculiar formation of its beak enables it to reach with ease, it will generally be found in plantations of evergreens. Essentially of a wandering nature, it never stays long in one locality, but leads a regular roving gipsy existence, frequently making its home wherever it happens to find itself in the breeding season, and from this cause it has nested at irregular intervals in many of the southern counties of England and in Ireland. The nest is always built on the fork or lateral branch of a fir-tree, and is composed of twigs, grass, and moss, lined with finer materials of the same kind.

The eggs are usually four in number and are pale blue with a few reddish spots and streaks towards the larger end. It is a very silent bird and has no song worthy of a name. The call-note is "gip-gip."

Insects and caterpillars are largely consumed during the summer, but seeds and berries form their chief food in winter.

When first hatched the bill in young birds is straight, but it assumes its characteristic shape very soon after they are fledged.

The adult male is crimson all over except the wings and tail, which are brown. The female is dark greenish yellow with striations of a darker tint. The young resemble the female but are greyer and greener. Young cocks probably do not assume their full plumage until the second or third year but they breed in their immature dress. Old cocks 138 



\section{CROSSBILL}

Loxia curvirostra

Male (below). Young (left). Female (above) 


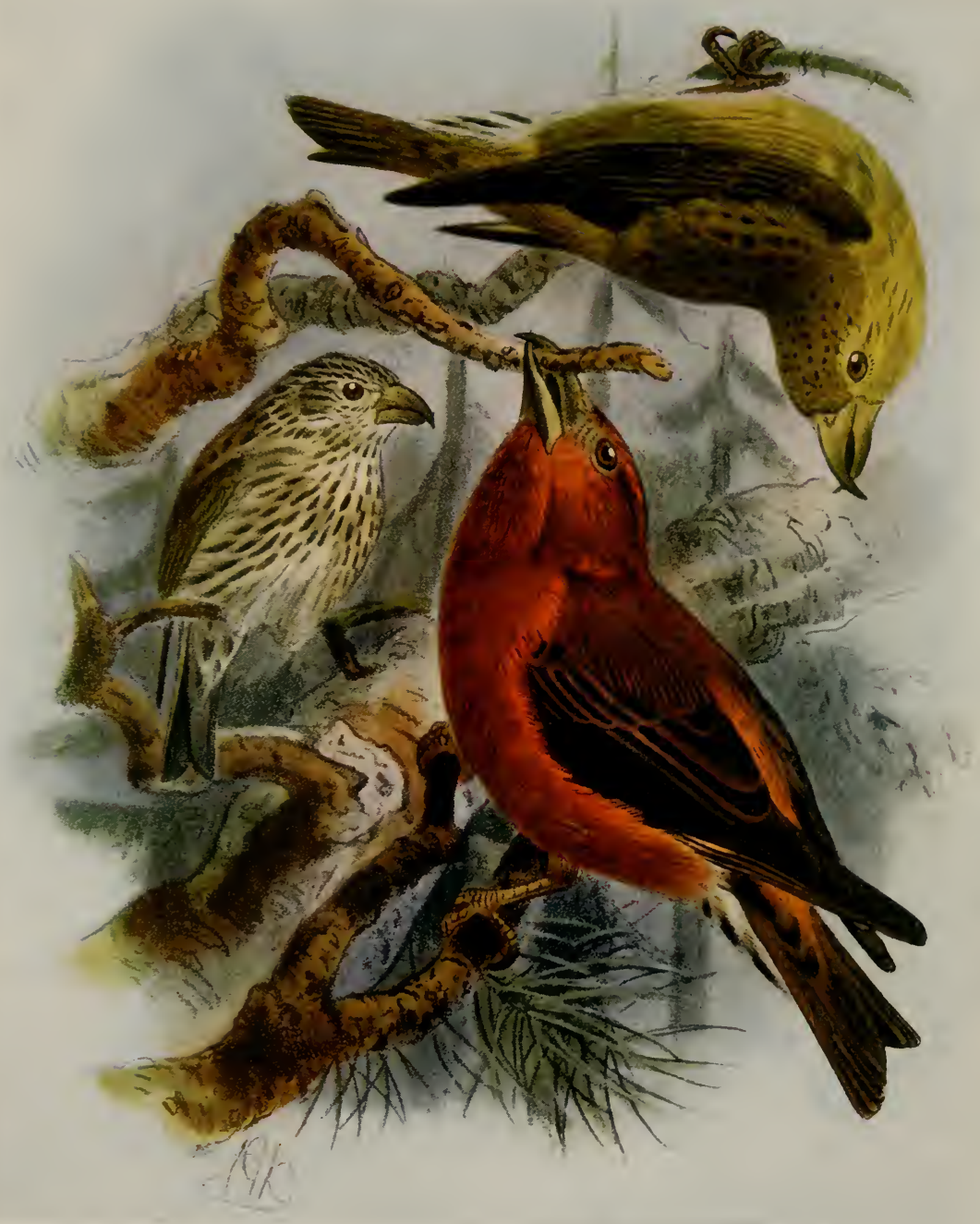





\section{The Crossbill}

lose the red and become golden yellow. Length 6.5 in.; wing $3.8 \mathrm{in}$.

The bill varies considerably in this species, and many individuals, which have a very stout bill, have been considered and named as a separate species, known as the Parrot Crossbill. These stout-billed individuals are most numerous in Scandinavia and Northern Russia, though they have been also obtained in this country, and their claim to specific rank is still a debatable point.

\section{THE TWO-BARRED CROSSBILL}

\section{Loxia bifasciata (C. L. Brehm)}

This species, whose true home is in Northern Russia and Siberia, has visited this country in small flocks on several occasions.

It may easily be distinguished from the Common Crossbill by the two white wing-bars; it is also rather smaller in size. Length 6.25 in.; wing $3 \cdot 7$ in.

\section{THE BLACK-HEADED BUNTING}

\section{Emberiza melanocephala, Scopoli}

The Black-headed Bunting must not be confused with the Reed Bunting, which is known in many parts of the country under the former name.

The true Black-headed Bunting is an inhabitant of I 39 


\section{Birds of Britain}

South-eastern Europe, but it occasionally wanders westwards and has been taken about four times in this country. The male has the head black, back brownish orange, and under parts bright lemon yellow. The female and young are yellowish brown, and the male in autumn has the bright colours obscured by rufous edgings to the feathers. Length 6.75 in. ; wing 3.7 in.

\section{THE CORN BUNTING}

\section{Emberiza miliaria, Linnæus}

One cannot well mistake this species, as he sits on the telegraph wires bordering the road, uttering times without number the long drawn-out "dzree-e-e" that serves him for a song.

In appearance he much resembles the Skylark, but, unlike that species, which is always so alert and ever on the move, the Corn Bunting spends most of his day sitting in an exposed situation on a hedge or on some tall plant in the open field. The nest is a fairly neat structure of grass, roots, and moss, with a lining of horsehair, and is usually placed on the ground in the middle of a field, and often at no great distance from a bush or some other post of vantage on which, as noted above, he spends the greater part of the day. The eggs are extremely handsome, being of a creamy white boldly blotched and scrolled with very dark brown. Insects and seeds are equally consumed, and both being abundant on the cultivated land, in which he delights, he earns an easy living with the minimum of exertion. 


\section{The Corn Bunting}

During the winter months he loves company and consorts with the Larks and Finches, generally roosting on the ground with the former.

The sexes are alike and have the upper parts pale brown streaked with a darker shade of the same colour. Throat whitish margined with brown spots; rest of the under parts buffish white spotted on the breast and flanks with brown. Length 7 in.; wing $3 \cdot 6$ in.

The young are rather darker and have the wing coverts broadly margined with fulvous.

It is by no means so abundant as the next species but is widely distributed in open, wild, or cultivated country.

\section{THE YELLOW BUNTING}

\section{Emberiza citrinella, Linnæus}

Day after day throughout the spring and early summer months the Yellow Bunting may be found, sitting on the topmost spray of a hedge and repeating with monotonous frequency his little song, which has often been rendered by the words, " $A$ little bit of bread and no cheese." It is neither long nor pretty, there is no music in it, and it is delivered without soul or fervour, yet in open and cultivated country, where the songs of the woodland birds are absent, it forms on a warm summer's day, a fitting accompaniment to the more ambitious performance of the Lark. Decked out in bright yellow livery toned down and shaded with other dark markings, the 


\section{Birds of Britain}

Yellow Bunting receives too little recognition at our hands and is not appreciated at his true worth. Harmless, bright, and sociable in habits, he may be found throughout the year in the open fields and hedgerows, and except during the summer months, when insects form a large portion of his diet, he is essentially a seed-eater, destroying in countless numbers the seeds of the various weeds that have a hard struggle for life amongst the cultivated crops.

The nest is a neat structure of grass, roots, and moss woven together and is lined with horsehair. Five eggs form the usual clutch; they are whitish streaked and veined, after the manner characteristic of this family, with purplish red.

In autumn the young and old visit the standing crops in family parties, and they pass the winter seeking their food on the ground in stubbles and fallows or visiting the stack-yards for the fallen grain.

The male has the head, throat, and under parts bright yellow, spotted or streaked, except on the throat, with dark brown. Mantle yellowish brown with darker streaks. Rump reddish brown. Wings brown with broad deep rufous edgings to the secondaries and wing coverts. Tail feathers dark brown with white spots near the tip of the inner web of the two outer pairs. The female resembles the male, but it is very much duller and darker in colour. The young are pale brown all over, lighter on the under parts and more rufous on the back, each feather having a dark central stripe. Length $6.5 \mathrm{in}$; wing $3 \cdot 25$ in.

This species is widely distributed throughout Great 



\section{YEILOW BUNTING (YELLOW HAMMER)}

Emberiza citrinella

Male (below). Young (above) 


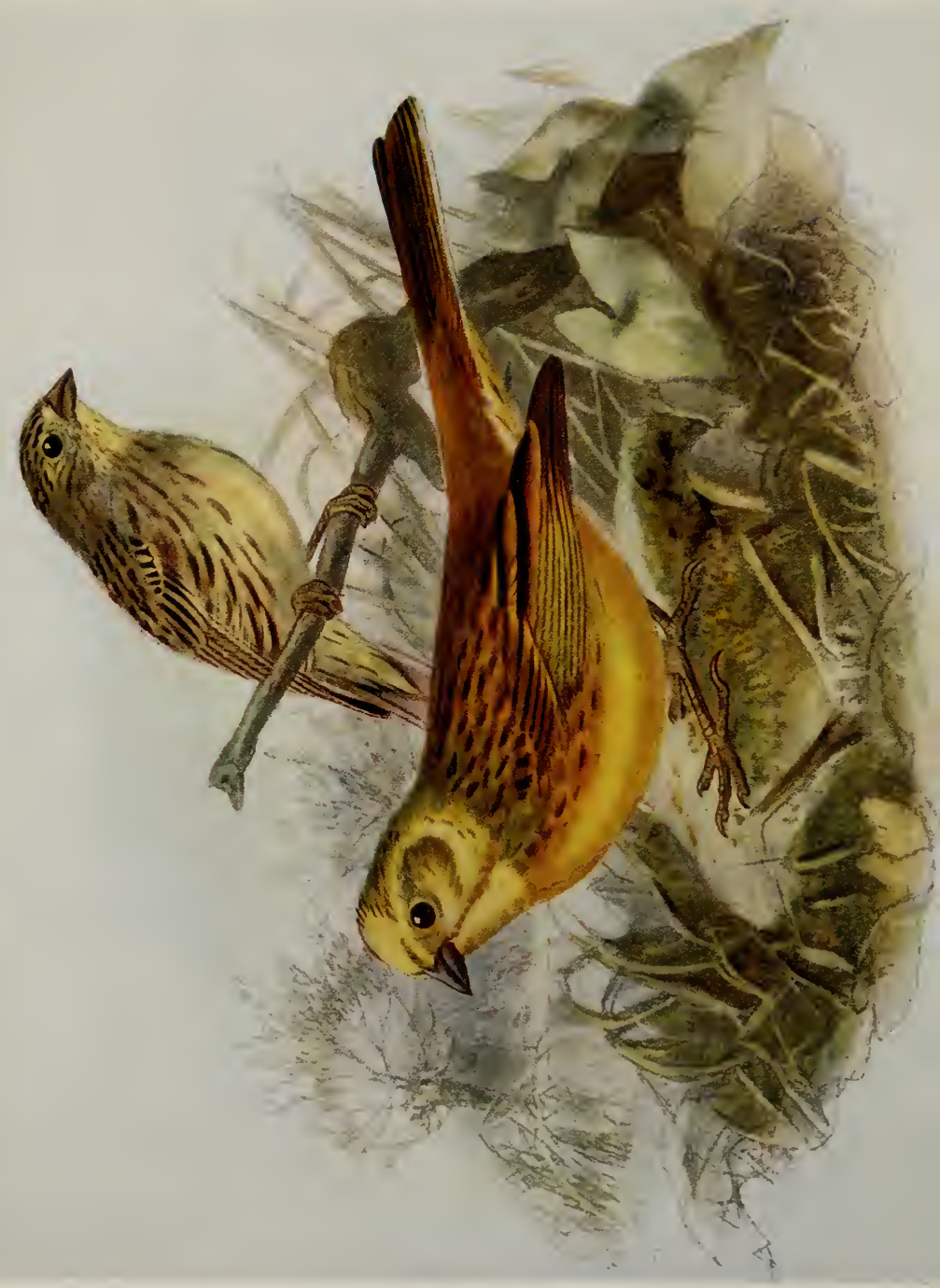





\section{The Yellow Bunting}

Britain, and is often known as the Yellow Hammer, the latter word being a corruption of "Ammer," the German word for a Bunting.

\section{THE CIRL BUNTING}

\section{Emberiza cirlus, Linnæus}

This species is very similar to the Yellow Bunting in habits and plumage, from which it may be most easily distinguished by the black throat and a black line through the eye. In our islands, however, it is very local and chiefly confined to the southern counties, but stragglers have been met with as far north as Yorkshire.

Although frequenting the hedgerows and open country it delights in trees, uttering its song from the higher branches of some hedgerow elm.

The nest is placed near the ground and constructed of similar materials to that of the Yellow Bunting, but the eggs differ in having the markings bolder and chiefly restricted to the larger end, and the hair lines, so numerous on those of the former species, are much fewer in number. Two broods are reared in the season, the young birds being fed on grasshoppers and insects, and the rest of the year is spent in the fields in company with other flocks of Finches.

The male has the top of the head and nape and rump greyish green, streaked with darker. Wing coverts and feathers of the mantle deep reddish brown with dark median spot or streak and broad light margins. Wing and tail dark brown. Cheeks yellow with black line through the 


\section{Birds of Britain}

eye. Chin and throat black, succeeded by a narrow yellow collar. Upper breast grey; lower breast chestnut. Rest of under parts pale yellow, becoming brownish streaked with darker on the flanks.

The female is much duller in colour and has the throat yellow. She closely resembles the hen Yellow Hammer, but may be distinguished by the absence of yellow on the head and by the lesser wing coverts being reddish brown and not black. The young roughly resemble the female. Length 6.5 in.; wing 3.25 in.

\section{THE ORTOLAN BUNTING}

\section{Emberiza hortulana, Linnæus}

Up to within the last few years this bird was so freely imported alive to supply the wants of epicures that a large number of its supposed occurrences in these islands are open to suspicion. There seems, however, little doubt, that genuine wild examples have reached these islands from time to time.

This species breeds sparingly in Scandinavia and thence southwards through Denmark, Germany, and France, but it is only in the south of Europe that it becomes common, migrating eastwards and southwards to Abyssinia and North India in winter.

The male has the head greyish ; rest of upper parts pale brown streaked with black. Throat yellow, becoming greyish on the upper breast ; rest of under parts pale chestnut. The hen is duller with darker streaks on the head. Length 6 in.; wing 3.25 in. 

CIRL BUNTING

Emberiza cirlus

Male (left). Young (right) 


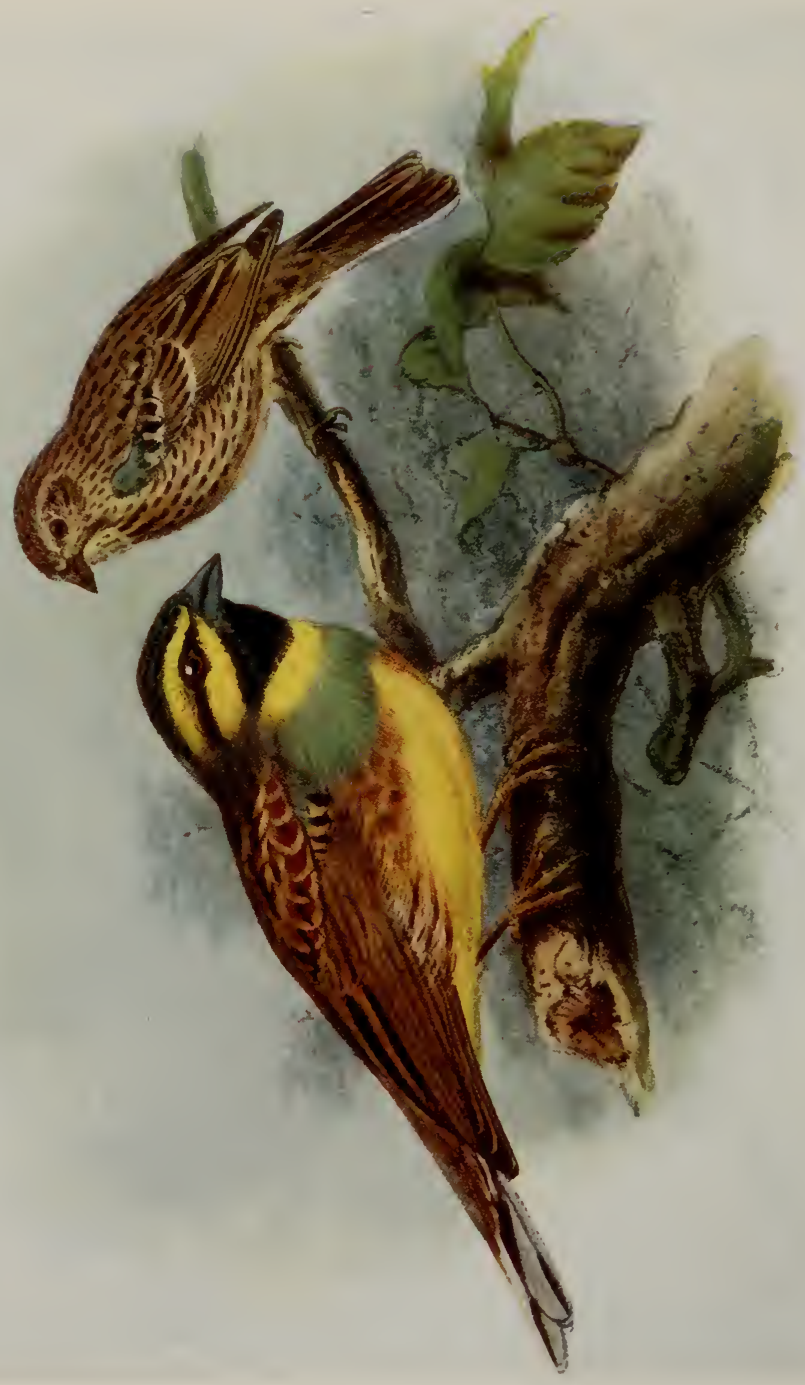





\section{The Meadow Bunting}

\section{THE MEADOW BUNTING}

\section{Emberiza cia, Linnæus}

This Bunting is found throughout Central and Southern Europe; it has only been recorded in this country during the last four years.

The head is blue grey, with three dark stripes across it; wings and tail dark brown, the secondaries edged with rufous; the whole of the rest of the plumage pale cinnamon brown with darker stripes on the back. Length 6.2 in.; wings $3 \cdot 1$ in.

\section{THE SIBERIAN MEADOW BUNTING}

\section{Emberiza cioides, Brandt}

This Asiatic species has only once been taken in Europe, namely at Flamborough Head in 1886. The colour of the upper parts is chiefly chestnut. There is a white superciliary stripe, and a white patch on the cheeks. The under parts are white with a chestnut band across the upper breast. Length 6.5 in.; wing 3.4 in.

\section{THE RUSTIC BUNTING}

\section{Emberiza rustica, Pallas}

This is an eastern species, nesting from Archangel eastwards across Siberia, migrating southwards in winter. 


\section{Birds of Britain}

Of late years it seems to have had a tendency to spread westwards, and stragglers have occurred throughout Europe, including Great Britain.

The adult male is a very handsome bird; the head is black with the exception of a white stripe behind the eye; the upper parts and a band across the breast, chestnut. Under parts white striped with chestnut. The female has the head brown mottled with black, and is otherwise much duller than the male. The young is brown above streaked with darker, the under parts whitish streaked with brown. Length 5.4 in.; wing 3.2 in.

\section{THE LITTLE BUNTING}

\section{Emberiza pusilla, Pallas}

The Little Bunting has a breeding range similar to the last species and occurs almost yearly on migration in Southern Europe, the south-east of France forming its western limit.

The male has the head chestnut with the exception of a black superciliary stripe; rest of the upper parts reddish brown streaked with darker. Chin and throat pale chestnut, under parts white streaked with black on the breast and flanks. The female is duller, and the young bird has the chestnut of the crown replaced by buff. Length 5 in.; wing $2 \cdot 75$ in. 


\section{The Yellow-breasted Bunting}

\section{THE YELLOW-BREASTED BUNTING}

\section{Emberiza aureola, Pallas}

This is an Arctic species, ranging in summer across Siberia eastwards from Archangel; in winter it migrates to Palestine and Southern Asia.

An immature female was shot in Norfolk in September 1905.

The adult has the forehead, cheeks, and chin black; rest of upper parts deep reddish brown, brightest on the rump; under parts bright yellow with a narrow chestnut collar across the upper breast. Length 5 in.; wing $3 \cdot 1$ in. The female is much duller, and in winter the colours in both sexes are obscured by long greyish margins.

\section{REED BUNTING}

\section{Emberiza schœniclus, Linnæus}

The Reed Bunting is an inhabitant of marshy places where osiers, alders, and long rough sedgy grass and reeds abound, and in such localities it is by no means uncommon. In summer the male may often be seen clinging to some reed stem, as he sings his very short and feeble song. Owing to his black head and white collar, which enable him to be very easily distinguished, he is known in some parts of the country as the Black-headed Bunting. The true Black-headed Bunting is, however, a very different 


\section{Birds of Britain}

bird, but it so rarely occurs in this country that the confusion likely to arise is not very serious. The nest is placed on the ground in the rough grass at the base of some shrub, or in the side of a tussock, and always near water. It is a fairly neat structure, built, like the nests of all Buntings, of grass, bents, and moss, with a lining of hair. The eggs, four to six in number, are very characteristic of this species, the ground colour is usually purplish gres, boldly blotched, marked and streaked with dark brown. Very handsome clutches are sometimes found, in which the ground colour is pale green, showing off the dark scrolls and blotches to great advantage. If the nest be discovered and frequently risited after the young are hatched, they will leave it at a rery early age, long before they can fly. In such cases, however, the anxiety of the parent birds as they fly round and round the spot soon leads to the discovery of their children.

Except under stress of weather, it is a very resident species, seldom leaving its farourite haunts, but sometimes in winter, when these are frozen over, it will be found in the fields consorting with large flocks of Buntings and Finches. As a rule, however, it is by no means gregarious, rarely more than ten or twelve being found together.

In summer the male has the whole of the head and chin deep black, surrounded by a white collar and having a white stripe along the line of the lower mandible. Mantle and wings black with broad rufous and grey edgings. Rump grey streaked with black. Under parts white striped with brown on the flanks. In winter the black and white of I 48 


\section{Reed Bunting}

the head and neck are largely obscured by pale brownish margins to each feather.

The fernale has the upper parts tawny brown with darker centres to the feathers. Under parts pale buff streaked with brown. The young resemble the female. Length 6 in, wing 3 in.

\section{THE LAPLAND BUNTING}

\section{Calcarius lapponicus (Linnæus)}

This species is only known to us by the appearance of a few stragglers that have wandered here from time to time in autumn and winter, though during the last few years its occurrences have been more numerous and regular, especially along our eastern and south-eastern shores. In its winter dress it bears at a distance a superficial resemblance to the Jark, and from being found in situations, viz. salt marshes near the coast, where the latter is also abundant it has probably frequently been overlooked.

It is another of those species whose home is circumpolar, and rears its young on the lonely tundras of Lapland, Noraya Zembla, and Franz Josef Land. In winter it moves southward, but becomes scarce south of the Baltic and is unknown in Italy, the south of France, and Spain. As mentioned abore, the adult in winter is not unlike a Lark at a distance, but in summer the male is a rery handsome bird. The crown, cheeks, throat, and breast are black, the hind neck is banded with deep chestnut, which 


\section{Birds of Britain}

is separated from the black of the head by a white stripe, which, starting behind the eye, runs backwards for a short distance and then turns downwards, to lose itself in the white of the abdomen. The rest of the upper parts are brownish with darker centres to the feathers, while the under parts are white with dark streaks on the flanks. In winter the brighter colours are hidden by long brown margins to the feathers which wear off in spring. The female retains her dull dress throughout the year.

The hind claw in this species is straight and longer than the toe. Length 6.25 in.; wing 3.6 in.

\section{THE SNOW BUNTING}

\section{Plectrophenax nivalis (Linnæus)}

Like the preceding species, the true home of this bird is also in the Far North; it has, however, a much wider breeding range, and a few pairs nest annually on the mountains of Scotland and in the Shetlands.

The nest is placed on the ground, hidden in a cleft of the rock or among loose boulders, and, as is characteristic of nests in holes, is very loose in construction. It is made of moss and dry grass, and is warmly lined with feathers. About six eggs, of a very pale blue spotted and zoned round the larger end with purplish red, form the clutch.

Unlike the Lapland Bunting, which is found in the salt marshes or on the tundras of the North, this species shows a predilection for the rocky coasts or hills covered with I 50 

SNOW BUNTING

Plectruphanes nivalis

(right)

L.APLAND BUNTING

Calcarius lapponiacus

(left)

Both in winter plumage 


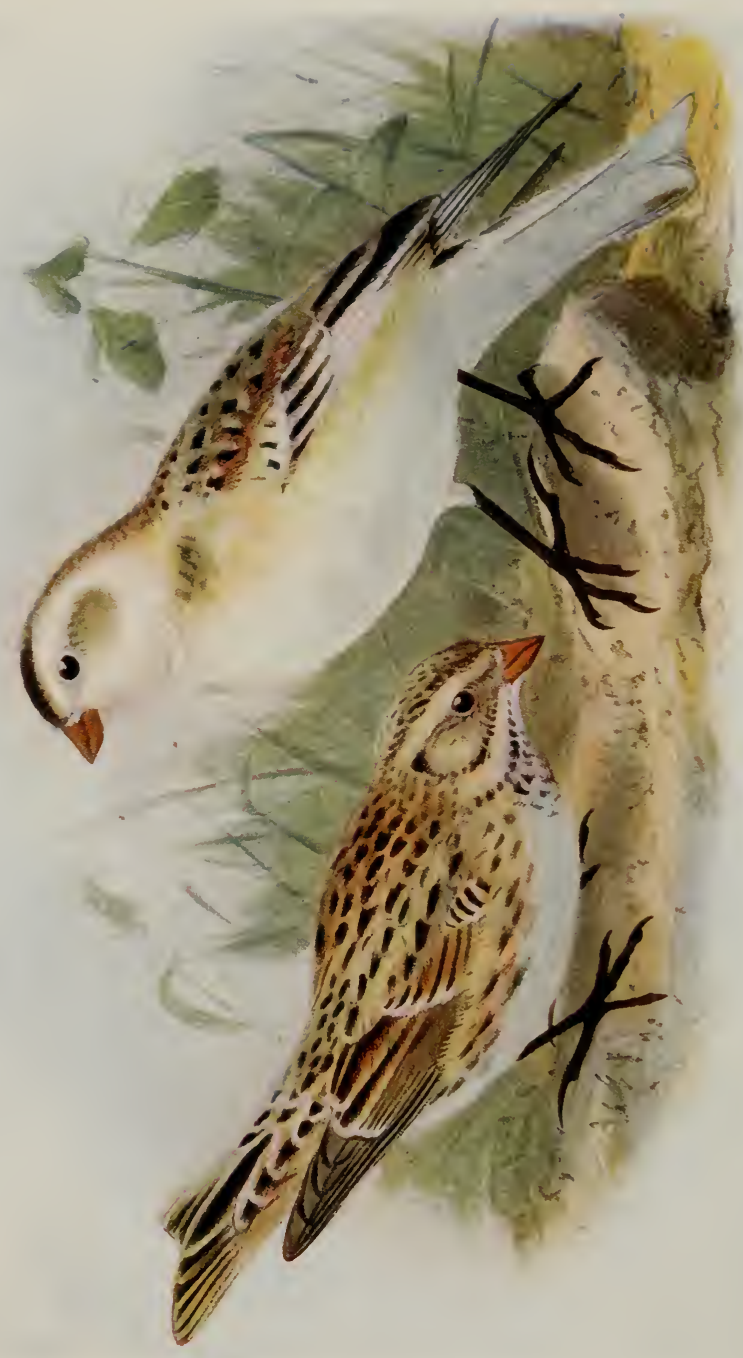





\section{The Snow Bunting}

loose boulders and is seldom found in the localities frequented by the former bird. In winter it is a regular migrant to our east coast, and also visits the west, but more sparingly.

In cold winters it becomes much more abundant, returning northwards, however, on the first approach of milder weather.

In summer the adult male has the back, inner secondaries, two-thirds of each of the primaries, and the six central tail feathers black, the rest of the plumage being white; the female resembles her mate but is rather smaller, the head and neck are streaked with greyish white, and there is less white on the wing.

In winter both sexes have broad tawny margins to the feathers of the back, while the head, breast, and flanks are largely suffused with the same colour. The young bird is greyish brown, spotted both above and below with a darker tint of the same colour. Length 6.55 in.; wing 4.4 in.

\section{THE STARLING}

\section{Sturnus vulgaris, Linnæus}

Except that it commits depredations in the cherry orchards as the fruit ripens, nothing but good can be said of the Starling. Tame, confiding, no mean songster, and an excellent mimic, he is very welcome wherever found. In autumn he congregates in vast flocks, whose numbers reach many thousands, and there must be few people who have not noticed these flocks go through their aerial evolutions, 


\section{Birds of Britain}

now drawing close together in a compact mass, or spreading out in wedge-shaped formation, rising and falling as though imbued with one mind. These flocks are to a large extent migratory, and in the evening will often collect to roost on reed-beds, which are laid flat with their weight. To enter such a spot quietly just after dusk and then make a noise, will afford one a sensation never to be forgotten, as they rise with a sound like rolling thunder, caused by the clattering of thousands of wings against the reeds, while others farther off, disturbed in turn, will also rise, until the whole flock is on the wing, circling round our head with a subdued roar which increases and diminishes as they approach or retreat. In a few minutes, however, if we remain quiet, they will soon begin to return, making no sound except the rattling together of the reeds as they settle, and in a few minutes all is quiet once more. At daybreak the flock divides into smaller parties which set out to forage in the neighbouring country. In the afternoon, as their hunger is appeased, the scattered flocks begin to collect again, and it is then that we may observe the evolutions referred to above, till finally at dusk they are all roosting once more in the reed-bed. After staying in the locality for some time, their numbers being increased by fresh arrivals daily, they will one night fail to return to their accustomed quarters, but will instead start on a long journey on which we are unable to follow them. Apart, however, from these large flocks, smaller bodies will be found throughout the winter, wandering over the country and even penetrating the parks and gardens of our large cities. In March and April a migration of small flocks returning to their accustomed breeding 

STARLING

Sturnus vulgaris

Adult (right). Young (left) 


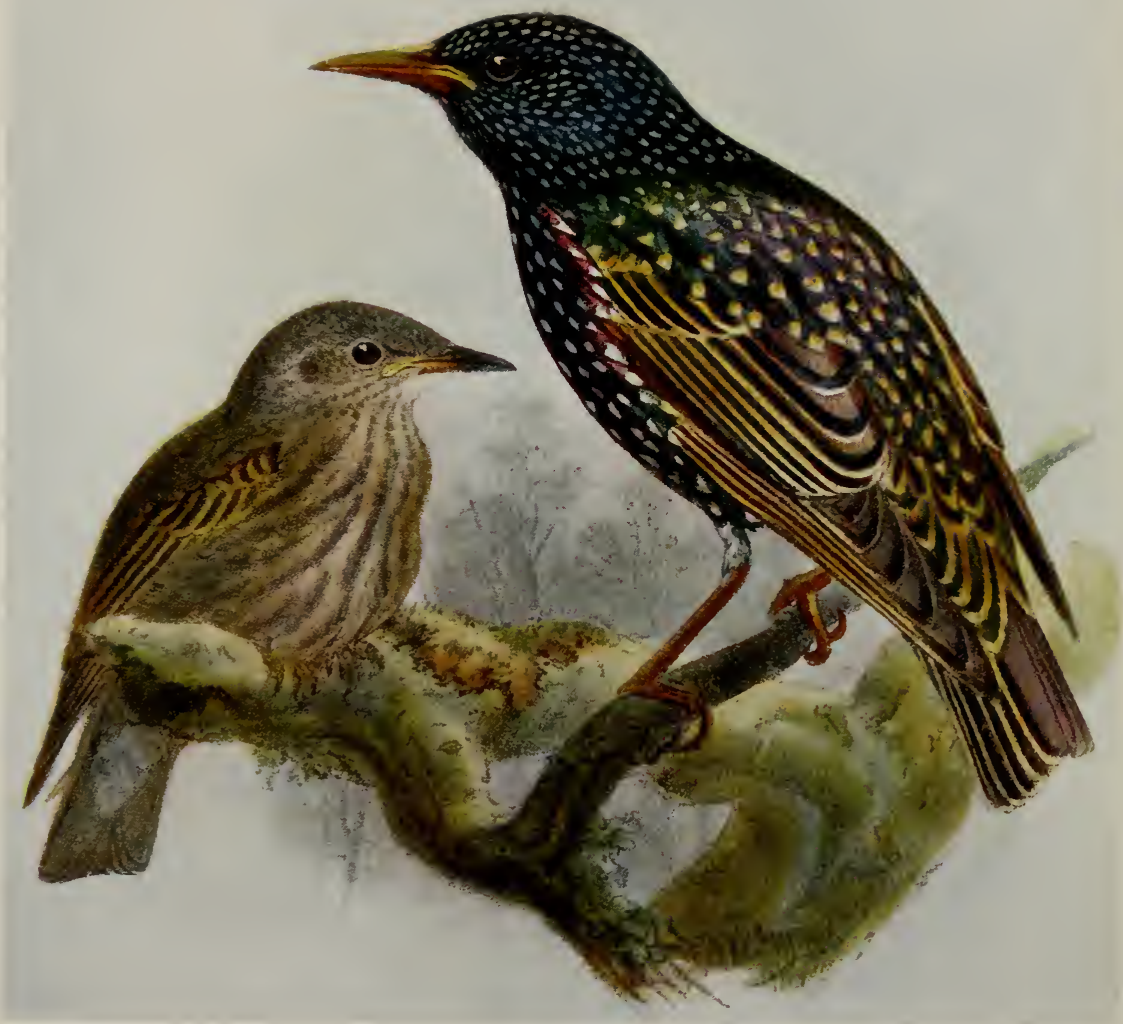





\section{The Starling}

haunts takes place, but the immense flocks of the autumn are never seen, and we can but suspect that Nature has in some way or other taken heavy toll of them.

Any hole in a tree or wall, the roof of a house, drain-pipes, church towers, or cliffs suit this species for a nesting-site. An untidy mass of straw, grass, and rubbish is collected to form a nest, and a few feathers, or wool, are added as lining. Five eggs of a uniform pale blue form the clutch, and two broods are reared in the season. The young when fledged begin at once to join with those from other nests and thus form the nucleus of the immense flocks which are, perhaps, one of the main characteristics of this species.

It feeds chiefly on insects, worms, and slugs, which are sought for in damp meadows and pasture-lands. It walks in a curious deliberate way, and on seeing a likely worm casting, it pushes in its closed beak, and after drawing it back with open mandibles, the hole, thus enlarged, is examined for the grub it may contain. It is also very partial to sheep runs, settling on the sheep's backs and relieving them of many and various ticks and parasites.

The sexes are practically alike and in winter the whole of the plumage is glossy black, with metallic reflections, the feathers of the upper parts being tipped with buff and those of the under parts with white. In summer it loses almost all the spots on the under parts and a large proportion of those on the back. The bill is lemon yellow in summer and blackish in winter. The young are greyish brown all over, rather lighter on the chin and under parts. In very old birds the feathers round the base of the bill wear off, leaving a bare patch as in the Rook. Length 8.5 in.; wing 5.2 in. 


\section{Birds of Britain}

\section{THE ROSE-COLOURED PASTOR}

\section{Pastor roseus (Linnæus)}

Eastern Europe and Asia is the true breeding home of this species, which wanders about in immense numbers, breeding gregariously wherever it happens to find itself at that season. Stragglers from these flocks often join with other migrating hosts of birds, and thus this species occurs as an irregular wanderer over the rest of Europe. The farther west, however, the rarer it becomes, and its occurrences in our islands, though noted from most districts, are not very frequent. It is about the size of the common Starling but has a longish black crest. Except for the back, shoulders, breast, and belly, which are rose pink, it is of a uniform metallic black. Length 8.5 in.; wing 5 in.

\section{THE CHOUGH}

\section{Pyrrhocorax graculus (Linnæus)}

This bird is one of the handsomest and at the same time our rarest member of the Crow family. With its glossy black plumage and brilliant red legs and beak it forms a beautiful sight to the ornithologist as he watches it flying over the wild and wind-swept headland that juts out into the Atlantic.

Its flight is extremely graceful and peculiar; a few beats of its wings, then it glides onward with outstretched pinions, 


\section{The Chough}

the ends of the outer primaries being well separated from each other; its wings close, it drops towards the ground, and then with a few more beats it recovers its former level and continues its flight. This species, which is only found on rocky coasts, is yearly becoming scarcer, but its chief enemy, if we except the ubiquitous egg-collector, is one of its own family, the Jackdaw. As this latter species extends its breeding quarters, so the Chough has to give way before it, being turned out of its nesting-holes till, weary of ineffectual attempts, it leaves the locality. In other places that king of Falcons, the Peregrine, will attack it, resulting in its very rapid extermination. This, however, is apparently an acquired taste on the part of certain Peregrines only, as we have known both species to nest on the same cliff without apparently interfering with each other in the least.

Any hole or fissure in the rock, or the ledge of some cliff, will provide this bird with a nesting-site, and a substantial cup-shaped structure of roots and twigs is built, and lined with wool, rabbit fleck, and hair. Three to five eggs are laid; they are pale greyish white in colour, spotted and streaked with grey or pale brown. Both parents attend to the wants of their young, feeding them on larvæ grubs and beetles. This species is almost entirely an insect-feeder and far less omnivorous than most of his kind, the long curved beak being especially useful for poking the soft earth or overturning the stones in its search for food. The note, which is very frequently uttered, is not unlike that of the Jackdaw but rather more metallic.

The adult is of a deep, glossy blue black all over. Bill and legs cherry red. The sexes are alike and the young 


\section{Birds of Britain}

only differ in having the bill and legs dull orange. Length $16 \mathrm{in.}$; wing $10.7 \mathrm{in.}$

This species is now only to be found in the wilder and more remote parts of the west of Scotland, Ireland, and Wales. A few solitary pairs may still be found in some parts of England, but they are rapidly disappearing.

\section{THE NUTCRACKER}

\section{Nucifraga caryocatactes (Linnæus)}

A few stragglers of this species have occasionally visited our east and south-east coasts in autumn, and at least two examples have been recorded from Scotland, but it has not so far visited Ireland. Fir forests in Scandinavia and Central Europe form the home of this bird, where it is resident and breeds early in the year while the snow is still on the ground. In appearance it is quite unlike any of our other species of Crow, being pale umber brown profusely spotted, except on the crown, with triangular white markings. Length 12 in.; wing $7 \cdot 5$ in.

\section{THE JAY \\ Garrulus glandarius (Linnæus)}

Considering the ruthless war waged on this unfortunate species by every gamekeeper throughout the country, it is 156 




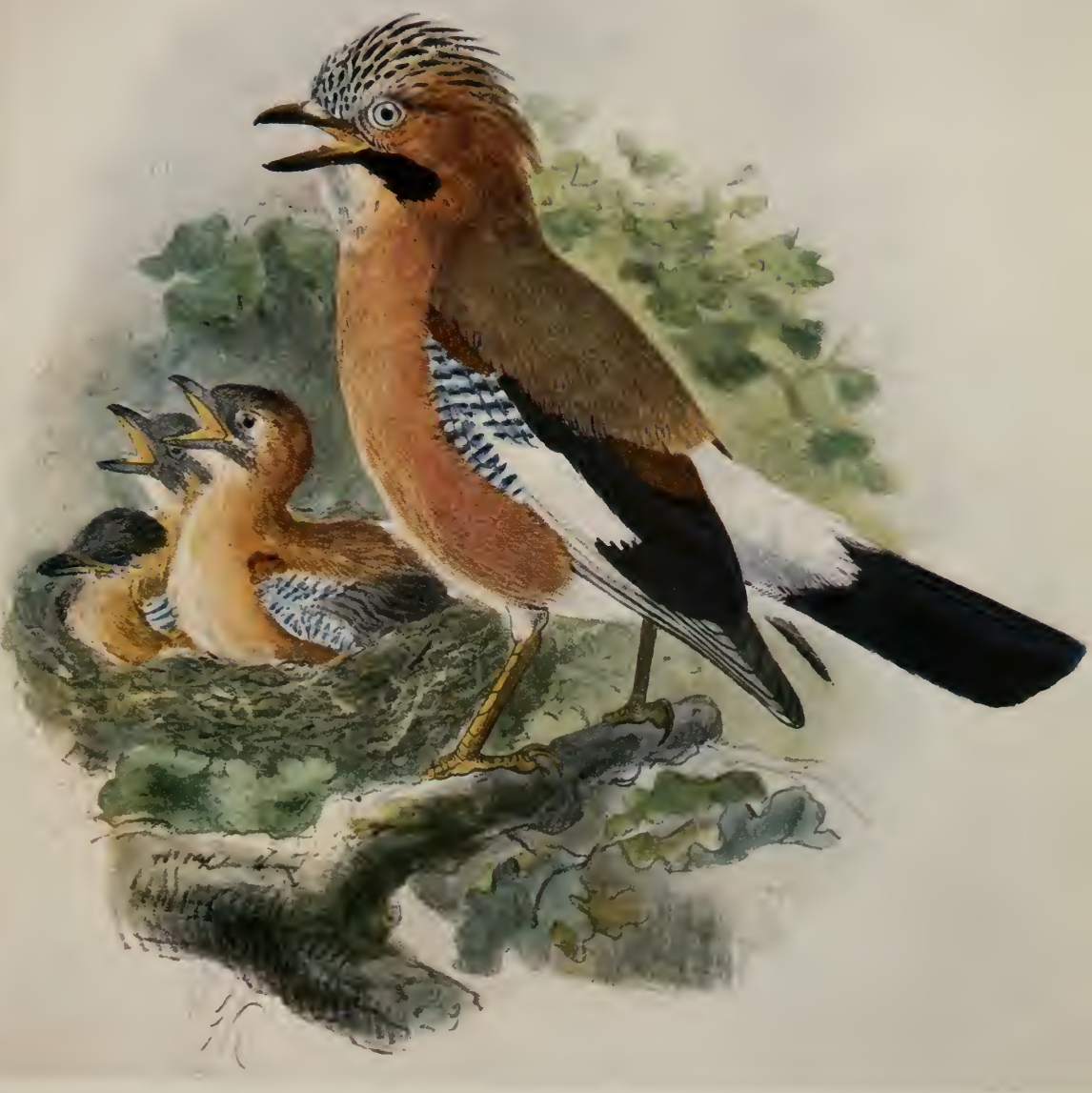





\section{The Jay}

little short of marvellous that we can still hear his harsh scream in most of our woods.

$\mathrm{He}$ is very wary and cautious, and spends most of his time, except when actually feeding, on the tops of the trees, flying off with many protestations to another part of the wood on the least sign of danger. His great supposed sin is the destruction of the Pheasants' eggs, though we doubt whether his depredations are sufficiently great to warrant his wholesale slaughter. The fox has been saved from extermination in the interests of hunting, and it is now conceded that, after all, his presence does not so greatly affect the interests of those whose sport lies with the gun rather than with the horse, and if only keepers could be taught to leave the Jay alone the loss of a few head of game, that would hardly be missed, would surely be more than compensated for by the sight of this beautiful species as he dodges through the wood in front of the beaters. No better watch-dog could be found, and many a trespasser will quit a wood owing to the tell-tale warning given by the Jay. Noisy and active as he is during the winter, he becomes in spring exceptionally quiet, and only when the nest is approached does he give any indication of his presence in the neighbourhood. The nest is generally placed some ten feet from the ground in the fork of a tender sapling and is made entirely of twigs and lined with fine roots. It is open and cup-shaped, and the eggs, small for the size of the bird, are pale green in ground colour, very thickly mottled with olive brown with, generally, a narrow black irregular line at the larger end. The young are chiefly fed on insects, spiders, and grubs, but 


\section{Birds of Britain}

this species is practically omnivorous and nothing comes amiss, large numbers of berries being eaten in winter. In this country he is strictly resident, rarely wandering far from the woods which formed his summer home, but in the northern parts of his range on the Continent he migrates, sometimes in considerable flocks, some of which visit our shores in autumn, and although these Continental birds are said to be distinguishable from our own native race, we suspect that it is largely owing to these immigrations that we can still number the Jay as one of our common indigenous birds.

The general colour of the nape, mantle, and under parts is vinous brown. Crown of the head whitish streaked with black; malar stripe black. Chin, rump, and under tail coverts white; tail and primaries black, the latter with white outer margins. Secondaries black, the outermost five with white bases. Wing coverts barred white, black, and blue. Length 14.25 in.; wing $7 \cdot 2$ in. The sexes and young are all alike in plumage.

This species is generally distributed, except in the north of Scotland and Ireland, where it becomes scarce.

It is perhaps worthy of note that in the Jays and Crows which build open nests, the nestlings have dark-coloured mouths with no marked light edging, whereas in the Jackdaw, that breeds in holes, the sides of the mouth are enlarged and whitish in colour and show up conspicuously in the semi-darkness of their home. 

MAGPIE

Pica nustica 


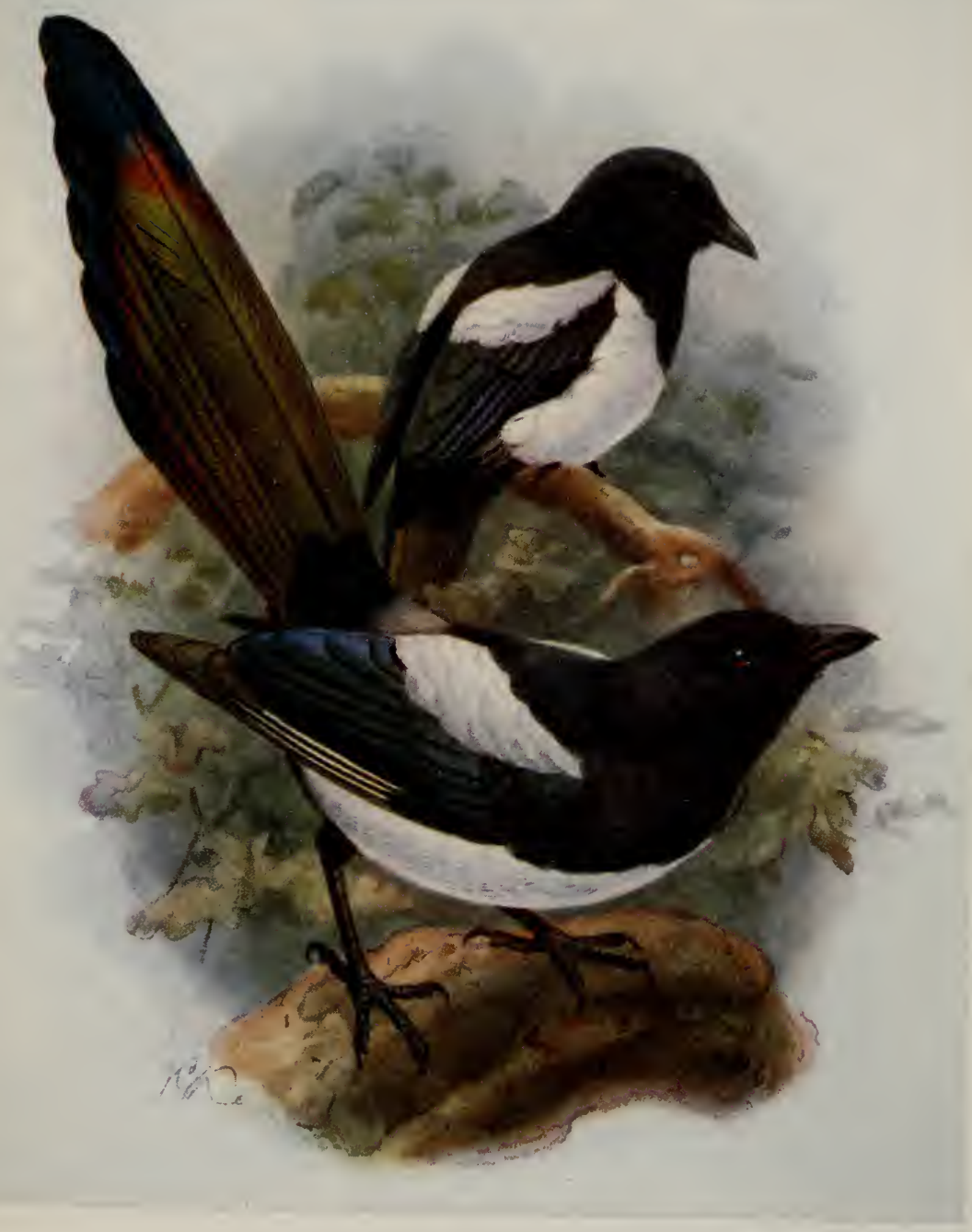





\section{The Magpie}

\section{THE MAGPIE}

\section{Pica rustica (Scopoli)}

This is another species against whom every man's hand in this country is raised. Being much less a bird of the woods and preferring to make its home in high trees growing in hedgerows, or even in tall hedges, it has unfortunately suffered much more than the Jay and is now very local in its distribution. Bold and omnivorous, it finds little difficulty in procuring a livelihood, and if it settles in the neighbourhood of a poultry or game farm it must be conceded that it will do considerable damage. On the other hand, it will also destroy countless worms, slugs, mice, and even young rats, so that it is by no means wholly mischievous, and in other countries where it is unmolested it becomes very tame and confiding, nesting in farm-yards or even in the towns, and those countries seem but little the worse for its presence. A fine showy bird, it is a pleasure to see him as he flies with rapid beats of his short wings across some field, rattling out his cheery chatter as he goes. What a perky chap he looks as he struts about on the fallow, or, having had his attention drawn by a strange object some yards off, approaches it with a few long hops and then with characteristic caution stops to examine it from a distance. Satisfied that it is harmless, he stalks to it with slow majestic walk, his head held high in the air and slightly inclined to one side; then suddenly he sees us-a harsh chatter and off he goes to the nearest cover. The nest is a huge domed structure substantially built of 


\section{Birds of Britain}

twigs, those with sharp spikes or thorns being used for preference. Inside, a deep cup is made of mud, and inside this again is placed a thick lining of grass. The eggs are six in number and of a bluish colour irregularly dotted, mottled, or splashed with olive brown. It is a strictly resident bird, rarely wandering far from its accustomed haunts and frequently going about in pairs.

The whole bird is glossy black with bluish and green reflections, except for the scapulars and belly, which are white. The rump is greyish. Length, including tail, $18 \mathrm{in.}$; tail 10 in.; wing $7 \cdot 75$ in. The sexes and young are all much alike in plumage.

\section{THE JACKDAW}

\section{Corvus monedula, Linnæus}

Abundant and gregarious in most parts of the country, this species may in winter be found associating with flocks of Rooks in the open pastures and arable land. It is a noisy bird and the call-note "che-ak" will generally warn us of its presence. It is found in all kinds of situations and localities, being equally at home in the wild open country, along the coast, rocky or alluvial, or on arable land, in well-timbered districts, and even in the middle of our busy cities; but from certain apparently suitable districts it is absent, and although abundant in some towns, in others it is hardly ever found. Along the coast where it does not occur, the Chough still holds its own, but as we noticed under that species the presence of the Jackdaw soon drives away the more delicate bird. 

JACKDAW

Corv'us monedula 


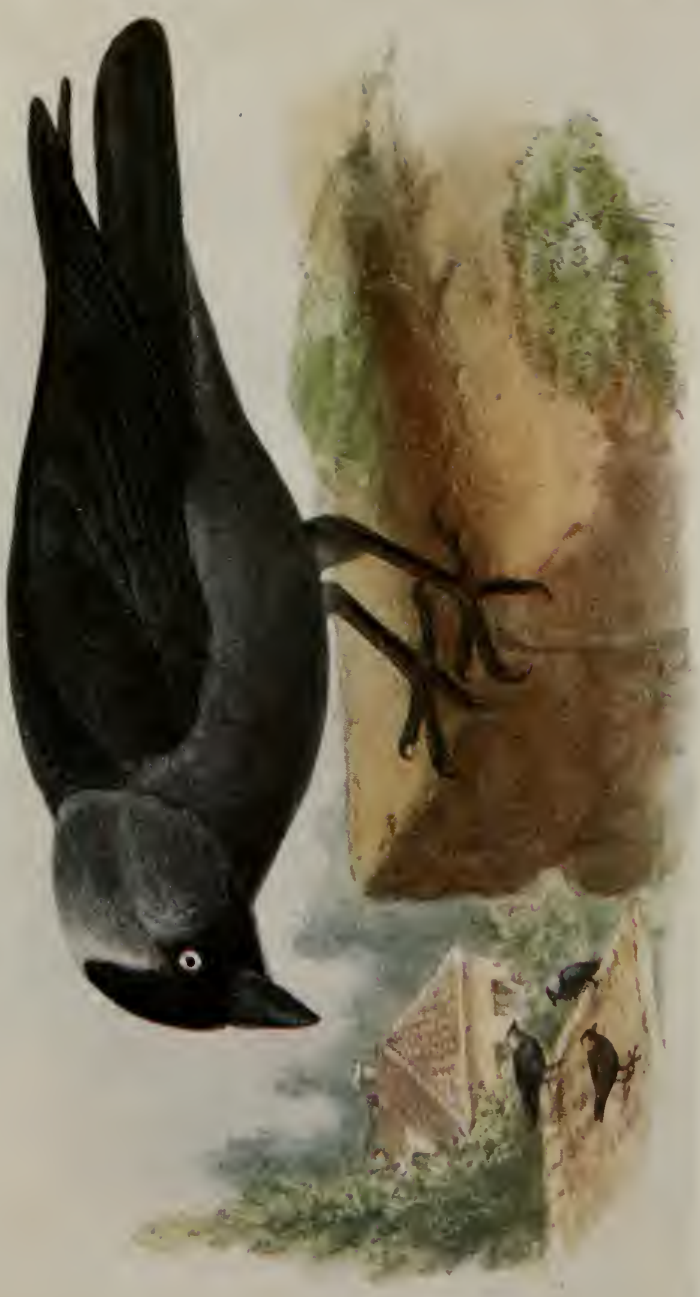





\section{The Jackdaw}

Practically omnivorous, he experiences no difficulty in procuring a living wherever he may be, but will usually be found associated with Rooks or Starlings on the pastures, often perching on the backs of sheep to rid them of the parasites with which they are infested. Holes in trees, walls, or ruins, church towers, chimneys, or cavities in rocks, provide suitable nesting-sites. A rough nest is built of sticks, lined with an abundance of fur, rabbit fleck, wool, and any other soft material.

The six eggs are pale blue in colour, with large distinct spots of olive brown.

Although this species is to be found among us at all times of the year, considerable migration both to and from these islands goes on in winter, large flocks sometimes arriving on our eastern coasts.

The sexes are practically indistinguishable, and are of a glossy purplish black on the head and back, and of a somewhat duller greyish black below. The occipital region, nape, and sides of the neck are clear grey, forming a sort of collar. The young birds are duller and lack the grey collar, which is only partially assumed in the first year. Length 13 in.; wing $9 \cdot 25$ in.

\section{THE RAVEN}

\section{Corvus corax, Linnæus}

There are few birds that can compare with the Raven in the majestic curves and sweeps of its flight as it skirts I6I 


\section{Birds of Britain}

the wild and rugged headland which forms its home, so that in spite of its occasional depredations on young and sickly lambs, it is unworthy of the persecution to which it is subjected. Scattered pairs are still to be met with round the rocky shores of England, while in the wilder parts of Scotland and Ireland it is still comparatively common. It chooses for its home some wild precipitous crag exposed to the fury of the south-westerly gales, and there it may be found at all times of year, ruling with uncontested sway some couple of miles of coast, where it feeds on any carrion or prey that can be found.

Early in the spring the old nest-a mass of sticks, driftwood, seaweed, and heather, warmly lined with wool and rabbit fleck-will be repaired, and at this season the male is magnificent to watch as he courts his mate in beautiful aerial flight. Early in March the eggs, three to five in number, are laid; they are bluish, densely speckled and blotched with olive brown. The female takes sole charge of the duties of incubation, while her mate, sitting near, keeps close watch and attacks with great boldness and fury any other feathered marauder.

Too often, however, their labours are in vain and man steps in and destroys the nest; but ever faithful to the old home, many pairs continue ineffectually to breed year after year near the same spot, till at last in their old age they succumb to some winter's storm and the spot is the poorer by the loss of one of our noblest birds.

After the young are fledged they remain with their parents for some months, till they are eventually driven out to make way for the new brood of the following year.

162 


\section{The Raven}

The adult is of a deep, glossy, blue black. The female and young only differ from the male in having less lustre on their plumage. Length 25 in.; wing 17 in.

\section{THE CARRION CROW}

\section{Corvus corone, Linnæus}

With every man's hand against it, the Carrion Crow, which as a scavenger might well be one of our most useful birds, leads a harassed existence. Singly or in pairs it wanders about the country, feeding on anything that comes in its way. Carrion is its chief delight, but in default of that it turns its attention to weak and sickly birds, mice, rats, etc., and, as is the case with other members of the Crow family, it does quite as much good by destroying vermin as it does harm by destroying eggs and young birds.

The nest is generally placed on the top of some high tree or on the ledge of a cliff. It is made of sticks with an inner foundation of mud and warmly lined with wool, bents, rabbit fleck, and hair. The eggs, three to five in number, are very variable in markings, but except in size resemble those of the Raven. For a short time after the young are fledged they wander about in family parties, but they soon separate, and after August more than a pair are seldom seen together, a fact which will help to distinguish it at a distance from the Rook, who is nearly always gregarious. In general appearance this bird is very like the Rook, but it may be distinguished by the following characters. The bill 


\section{Birds of Britain}

is much stouter and broader and not so long and slender; its colour is black with a greenish gloss and not of a purplish blue, and the feathers have white bases, while those of the Rook are grey; the bristles and feathers at the base of the bill are never worn away as is always the case with Rooks after their second moult. Length 19.5 in.; wing $13 \mathrm{in.}$ In this country it is generally distributed where not too strongly persecuted, becoming commoner in Scotland; but in Ireland it is very rare.

\section{THE HOODED CROW}

\section{Corvus cornix, Linnæus}

The question as to whether this bird, which interbreeds freely with the Carrion Crow where their ranges overlap, is or is not a good species need not trouble us here. Suffice it to say that in England it occurs numerously as a regular winter immigrant, large numbers crossing the North Sea and arriving on our eastern coasts. Over the rest of our islands its distribution is somewhat capricious. In Wales and the western counties it is rare, whereas in Ireland and Scotland it is well distributed and resident.

In habits it resembles the Carrion Crow but is more found on the sea-shore and estuaries than that species, though it is also found in the wooded districts. The back, shoulder, breast, and under parts are ashy grey, the rest of the body being black as in the Carrion Crow, of which in size and all other respects it is the exact counterpart.

$$
164
$$




\section{The Rook}

\section{THE ROOK}

\section{Corvus frugilegus, Linnæus}

There is no more delightful sound in early spring than the "caw" of the Rooks at their " rookeries," as their breeding places are called. Year after year they return regularly to the same clump of trees, on the tops of which they build a fairly substantial nest of sticks, with an inner foundation of mud which is in turn warmly lined with roots, straw, and fine grass. The sites chosen for their homes are more frequently than not near human habitations or on clumps of trees near a highway, and exceptionally, they may choose pollards or low bushes, but as a rule the nests are never less than twenty feet from the ground. The eggs are bluish, with olive brown spots and blotches resembling those of the Carrion Crow, but smaller and more variable.

The young leave the nest just before they can fly, and may then be seen sitting on the topmost branches of the trees as they sway in the wind. This is the time when they are shot for rook-pies, and also under the impression that if they are not thinned out the colony will be deserted. For this belief we are not aware that any proof exists, but curiously enough colonies left to themselves tend to diminish. These birds are rather capricious and will occasionally, even in the nesting season, desert the colony; the presence in the neighbourhood of a pair of Carrion Crows is sometimes the cause, but more often than not the reason is not apparent. As soon as the young can fly, towards the middle 


\section{Birds of Britain}

or end of May, the rookery is deserted : old and young keep together and wander about the fields and arable land, digging deeply with their powerful bills in search of larvæ and grubs, and destroying countless numbers of wire worms, that renowned pest to agriculture. In this country it does not migrate to any extent; certain plantations are used as regular roosting-places, and as evening draws on in the winter months, long strings of these birds may be seen slowly flying in their heavy characteristic manner to their nightly shelter. Although the flight appears heavy and laboured, they in reality travel at no mean pace, and in their daily search for food often cover great distances. As in the case of Jackdaws and Jays, there is a large immigration yearly on our east coast during October and November, for in Scandinavia and the northern portions of its breeding range it is a regular migrant. Throughout the whole of our islands it is a common bird, but is rather more local in Scotland, and it is only of recent years that it has regularly bred in the extreme north. From continual digging in the ground the feather follicles round the base of the bill become destroyed, leaving a whitish patch of bare skin which is an unfailing characteristic of the adult birds. In young individuals, however, the feathers extend to the base of the bill and do not appear to be permanently lost till during the second autumn moult. The sexes are alike; their colour is a uniform deep and glossy purplish blue. The young resemble their parents, but lack the gloss to their feathers. Length $19 \mathrm{in}$; wing 12.65 in. 

ROOK

Corvus frugilegus

Adult (right). Young (left) 


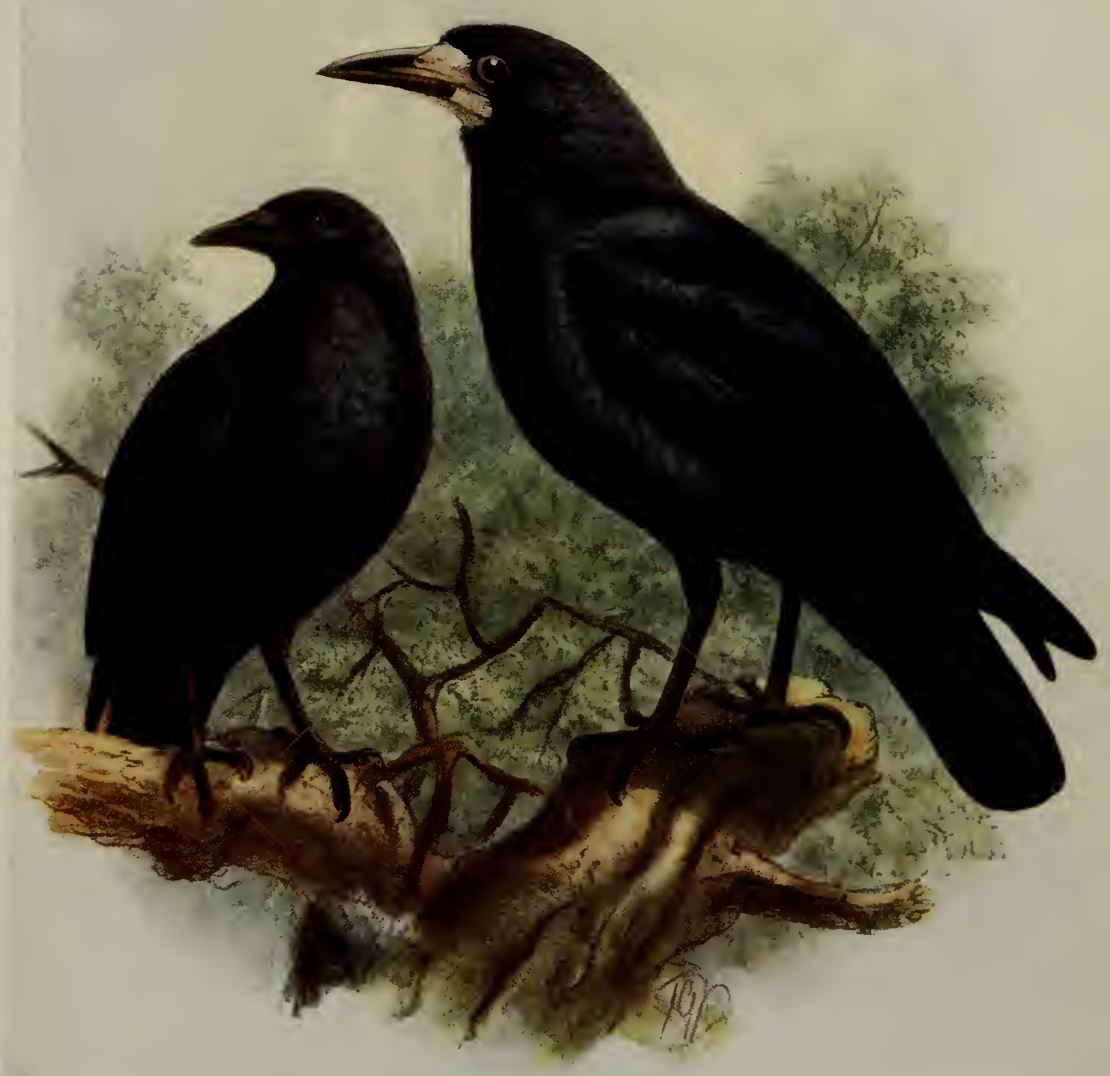





\section{The Skylark}

\section{THE SKYLARK}

\section{Alauda arvensis, Linnæus}

Of all other birds the Lark is perhaps the one which typifies most thoroughly the freedom of life, and brings to our minds scenes of wide open country, where, bright, free, and unrestrained, he pours forth his song in the boundless expanse of the air.

Hatched in a neat nest of bents and dry grass lined with finer materials and placed on the ground in the middle of an open field, the youthful Lark has early to contend with enemies. Mice and other ground vermin, or the heavy foot of some grazing cattle, frequently destroy the nest and its contents, and the fact that so many escape must be largely ascribed to good luck.

His food is of a very varied nature and nothing comes amiss. The young are fed exclusively on insects, but after leaving the nest they spend their time eagerly feeding on seeds, berries, or anything that comes their way. As summer wanes, giving place to autumn, they collect in large flocks and seek the stubble fields, where the scattered grain gives them abundant nourishment, and on which they become very fat. It is at such times, while they are asleep by night, that they are netted by hundreds for the market. This form of catching can, however, only be successfully carried out shortly after dark on the blackest of nights, for, like all wild animals, they seem to rest with one eye open, and should there be the faintest glimmer of light they will 


\section{Birds of Britain}

be up and away long before the bird-catcher is near them. In October they become restless, and many wander to the coast, and thence to other countries, their place being taken by the inhabitants of more northerly climates. So the months pass, until a northerly gale and severe frost moves even these hardy northerners, and at such times they may be seen migrating in millions (for they travel almost entirely by day), relentlessly pursuing a southerly course in front of the biting norther. With a change of wind and temperature a large number will drift back again, but the movement will not be so noticeable, and thus they pass their lives, wandering wherever the weather and food may dictate, till in the very early days of spring, or even on fine days throughout the winter, we may hear their voluble song, breathing as it does the joy of freedom in every note. This is almost always uttered on the wing. Springing from the ground with rapid, fluttering wings, he rises perpendicularly higher and higher till he is almost lost to sight in the clouds, though his song still drifts down to us with unaffected clearness; higher and higher he goes, and then in a spiral curve he slowly descends, the song ceasing as he reaches a spot within a few feet of where he rose.

Nest-building is begun in April, and several broods are reared in a season, the song being continued except when he is actually feeding young in the nest.

The adult has the general plumage of a warm brownish tint, mottled and streaked with a darker shade. There is a light-coloured superciliary streak. The chin, throat, and upper breast and flanks are brownish buff streaked with brown, rest of under parts yellowish white. The sexes are 

SKYI_ARK

Alauda arvensis

Adult (left). Young (right) 


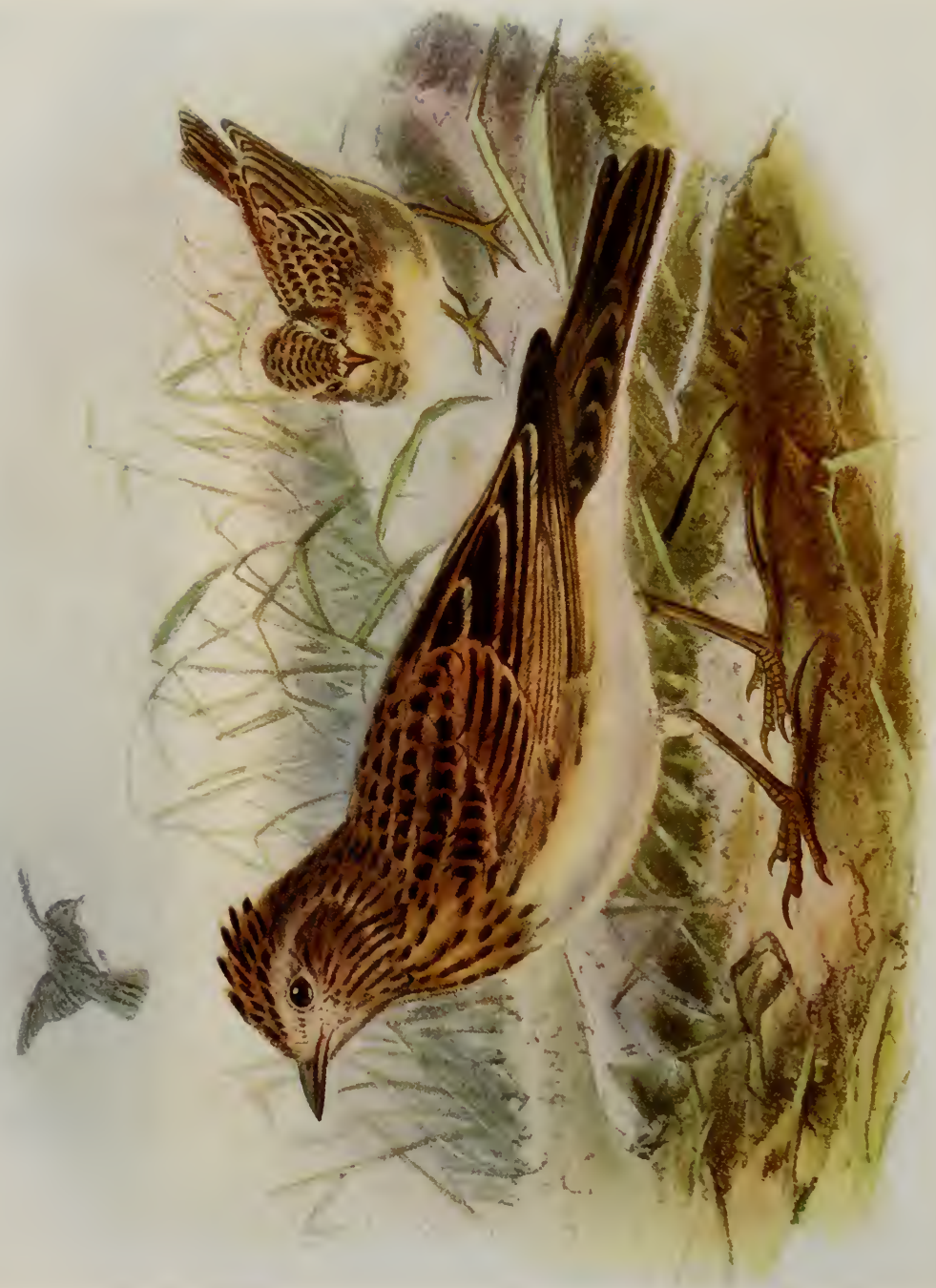





\section{The Skylark}

alike in plumage but the female is rather smaller. Birdcatchers measure them from tip to tip of the expanded wings, rejecting those which are under one foot, as females. The young have the chin and throat unspotted, and have pale edgings to the feathers of the upper parts. Length about 7 in.; wing (of male) 4 to 5 in.

\section{THE WOOD LARK}

\section{Alauda arborea, Linnæus}

The Wood Lark is a much rarer bird than the Skylark, and very local in distribution. Rows of trees bordering open fields are the localities chiefly favoured by this species, which, except that it frequently perches, and may often be heard singing from the topmost branch of a tree, much resembles its commoner congener in habits. It feeds almost entirely on the ground, living chiefly on insects. The nest is placed a few yards from the hedge and composed of bents and grass, with a lining of finer materials. The eggs, usually four in number, are of a creamy ground colour, very thickly freckled with reddish brown markings. This species may be most easily distinguished by its song, which is much sweeter and fuller in tone than that of the preceding bird, but lacks the power and exuberance. When rising from the ground to sing, it always does so in a wide spiral curve, differing in that respect also from the Skylark, which rises straight.

The sexes are alike in plumage and resemble the Sky-

$$
\text { I69 }
$$




\section{Birds of Britain}

lark, but it is a smaller bird and has a short hind toe and is more heavily streaked on the back. Length 6 in.; wing $3.6 \mathrm{in}$.

\section{THE CRESTED LARK}

Alauda cristata, Linnæus

The Crested Lark is a common species on the Continent, even as close to our shores as the north of France, but very few examples have been known to stray to this country. It is not gregarious like the Common Skylark, and the song is not usually uttered on the wing, but in food and other habits it does not differ much from our well-known species.

In general colour this species is much duller, and the beak is longer and stouter than the Skylark, but its chief characteristics are the long pointed crest, the large bastard primary, and the absence of white on the tail. Length 6.75 in.; wing $4 \cdot 1$ in.

\section{THE SHORT-TOED LARK}

\section{Alauda brachydactyla, Leisler}

This bird is a resident, or partial migrant, throughout the whole of Southern Europe, but it has been known to occur in Northern Germany, Belgium, and the north of France. In Great Britain about half-a-dozen examples have been taken at various times in the south and east.

Very similar in appearance to other Larks, but, as its 


\section{The Short-toed Lark}

name indicates, the hind claw is short. The under parts are white and unspotted except for a few streaks on the sides of the neck. Length 5.5 in.; wing 3.4 in.

\section{THE WHITE-WINGED LARK}

\section{Alauda sibirica, J. F. Gmelin}

This species breeds across Central Russia and through the Kirghiz steppes as far as the Altai, migrating southwards in winter. Has only once occurred in England. The bill is short and stout, and this species may be at once recognised by the white inner primaries and secondaries, which form a conspicuous patch. Length $7 \cdot 5$ in.; wing 4.6 in.

\section{THE BLACK LARK \\ Melanocorypha yeltoniensis (Forster)}

This species inhabits South Russia, Transcaspia, and Western Siberia. In the winter of 1906 a small flock, consisting of both males and females, arrived in Sussex, being presumably driven westwards owing to the severity of the weather.

The male has the entire plumage jet black, but in winter this colour is largely obscured by broad sandy margins to the feathers. The female is pale sandy brown with darker markings, under parts white, spotted on the throat and breast. Length about $7 \cdot 7$ in.; wing $5 \cdot 3$ in. 


\section{Birds of Britain}

\section{SHORE LARK \\ Otocorys alpestris (Linnæus):}

A very different bird is this from the other Larks with which we have been dealing. $\mathrm{He}$ is seldom seen in this country, and then only in small numbers and at irregular periods.

The wide tundras of the North form his home, and there he may be found plentifully, but as the long Arctic day gives way to the cold black night, he reluctantly retires and passes the winter in the temperate portions of the northern hemisphere. In these islands we are just on the fringe of his wanderings, and almost every year a few stragglers put in an appearance on our eastern coast in autumn; their visits are of but short duration, and as a rule they quickly pass away southwards. With very severe weather on the Continent, however, they may appear in some numbers towards midwinter, and at such times remain with us till at the first sign of coming spring they are off again to their dearly loved home in the North.

General colour above pale sandy brown, tinged with rufous on the back of the head and nape. Forehead and a superciliary stripe white; a band across the head, lores, cheeks, and a triangular band across the chest, black; rest of under parts white, inclined to rufous on the breast and flanks. The female is smaller and duller. Length about 7 in.; wing 4.4 in. 


\section{The Swift}

\section{THE SWIFT}

\section{Cypselus apus (Linnæus)}

The causes that govern the migratory movements of birds are still unknown. Some species are doubtless impelled by stress of weather or lack of food to seek other quarters, but what power can it be that brings the Swift thousands of miles from another continent to lay its eggs and rear its young, and then precipitately to retire again when the flies on which they feed are most abundant, and the warmest month of the year has hardly begun? It is one of the last of the summer birds to arrive, May being generally well advanced before we hear its harsh yet pleasant scream of "swee ree," as it swerves in rapid flight round the cottage or belfry which is to form its summer home.

This species is the most aerial of all our native birds, and is never seen to settle except when entering the hole under the eaves where it nests, and, in fact, owing to the length of its wing and shortness of its legs, it cannot raise itself from a level surface should it once settle.

Gregarious in its habits, it returns yearly to the same place, and, entering through a hole or crevice under the eaves, nests there in security. Swifts, as a family, differ from all other birds in using a sticky, mucous saliva, with which to bind together rough bits of straw, cobwebs, feathers, etc., which form their nest. The nests of certain foreign species are formed entirely of this saliva, and such nests are eaten with great relish and in large quantities by the 


\section{Birds of Britain}

Chinese. With our species, however, the amount of saliva used is comparatively small; it does not often collect material for its nest, but makes use of the accumulation of rubbish usually found under roofs, and, hollowing out a shallow depression, cements it into a permanent cup. Two or three dull, oblong, white eggs form the clutch. The young when first hatched are naked; they stay in the nest a long time, not leaving it until fully fledged. When, however, they leave their home and drop into the air for the first time, they fly off at once and appear as much at home on the wing as their parents. For a few days they return to the nest to rest, and then a week or two after they are fledged, about the beginning of August, they leave us for their tropical winter home. These birds occasionally perform curious aerial evolutions on warm summer nights. As darkness comes on they become very restless, screaming round the tower or belfry as they dash by in wide circles; gradually they rise higher and higher in the air till they become mere specks, and are finally lost in the darkness.

Here again our ignorance comes in and our story must end. Observers have sat up in vain till two or three in the morning, awaiting their return. Not one has reappeared, and yet the next day they will all be seen back again, apparently unwearied by their restless night, but rather enjoying to the full the marvellous powers of flight which they have inherited.

The sexes and young are alike in plumage and are of a uniformly dark sooty brown, the chin and throat being dull white. The tail is short and slightly forked; wings very long and narrow. The feet are extremely feeble, the 




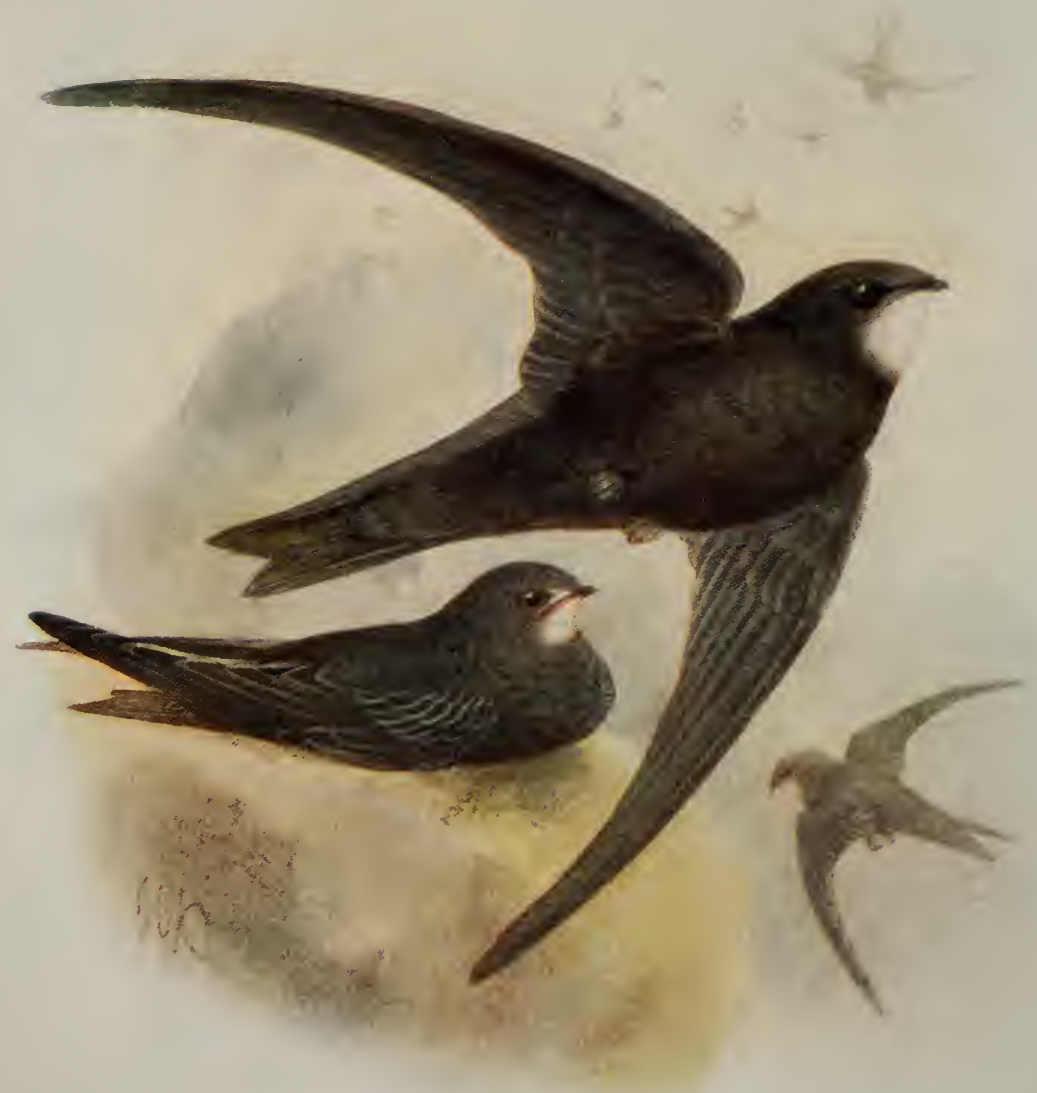





\section{The Swift}

four toes all directed forward and having sharp, recurved nails, which enable them to cling to perpendicular surfaces. Length $6.5 \mathrm{in}$; wing $6.8 \mathrm{in}$. It is generally abundantly distributed throughout our islands, but becomes scarcer in the North. It winters in Africa.

\section{THE ALPINE SWIFT}

\section{Cypselus melba, Linnæus}

This is a much larger species than our common Swift and has only visited these islands on very rare occasions, almost all the examples obtained having been taken in the south of England. It breeds in the high mountain ranges of Central and Southern Europe, and winters in Africa. From our common species it may be distinguished by its larger size, browner colour, and light under parts. Length 8 in.; wing 8.45 in.

Another species, the Needle-tailed Swift (Acanthyllis caudacuta) has occurred on two occasions in England. It breeds in Central Asia, migrating in winter to Australia, and except for these two instances is unrecorded from Europe.

\section{THE NIGHTJAR}

\section{Caprimulgus europæus (Linnæus)}

Arriving, the latest of all our migrants, towards the middle of May, and leaving again early in September, this 


\section{Birds of Britain}

strange bird is but little known to the majority of people, although by no means uncommon in suitable localities.

Its favourite haunts are gorse commons, and moorlands on the edge of woods, especially where bracken grows freely, and in such situations it may be found throughout our islands. The best time to see it is at dusk, when it comes out to capture moths, beetles, and other crepuscular insects which form its chief sustenance. Its flight is silent and very bat-like, twisting and turning with great ease and agility, now and again striking its wings together with a loud clap and uttering at the same time a sharp little whistle. When resting on a branch, which it invariably does lengthways, a curious reeling note or vibrating "churr" is uttered.

No nest is made, but the two white eggs, boldly blotched and mottled with brown and lilac, are laid on the bare ground without any attempt at concealment. The bird sits very closely, and her dull greyish plumage so assimilates with her surroundings that it is almost impossible to see her until she rises and circles round, uttering a harsh "chuck, chuck."

The young, when first hatched, are covered with an ashy grey down, and have, even at this tender age, the large mouth with enormous gape, characteristic of this family. They do not remain in the nest till fledged, but crawl about on the ground. They do not, however, attempt to feed themselves, and are carefully tended by their parents till they are well able to fly, when they at once quit this country to winter in tropical Africa.

The plumage of both sexes is nearly alike, and is ashy 176 


\section{The Nightjar}

grey, streaked and spotted irregularly with brown. The male has a white spot near the centre of each of the three outer primaries, and the two outermost pairs of tail feathers are tipped with white. These white markings are absent in the female. The young practically resemble the female Length 10.5 in.; wing $7 \cdot 55$.

One example each of two other species of this family, the Red-necked Nightjar (Caprimulgus ruficollis) and the Egyptian Nightjar (Caprimulgus cegyptius) have been taken in England. The first named is a native of Southern Spain and North Africa as far east as Tunisia; the breedingquarters of the other are in South-east Europe, Egypt, Nubia, and Tunisia. In general appearance they both closely resemble our common species; the Red-throated may, however, be recognised by the tawny collar encircling the head, and the Egyptian by the inner webs of the primaries being pure white.

\section{THE WRYNECK}

\section{Iynx torquilla, Linnæus}

Under the name of the "Cuckoo's Mate" this species is well known in our southern and south-eastern counties. Elsewhere in England it is rare or local, and in Scotland and Ireland it is of very irregular occurrence. The name "Cuckoo's Mate" is derived from the fact that its arrival usually coincides pretty closely with that of the Cuckoo, namely during the first week in April, but in other respects 


\section{Birds of Britain}

it has no connection in habits or distribution with the better-known species. Owing to its dull and unobtrusive plumage, and more especially from its custom of inhabiting gardens and woods, it is not easy to see, though to those who know its note, which is a sharp "qui, qui, qui," its presence will be frequently made known. It feeds chiefly on ants, which it searches for on the ground or on tree-trunks. These are rapidly conveyed to its mouth by a quick motion of its long extensile tongue, which is coated with a sticky mucus, and the rate at which this organ is shot forwards and backwards is almost incredible, and reminds one rather of the tongue in the chameleons and some other lizards. It breeds in the hole of a tree, and the six round white eggs are laid on the wood itself without any attempt at a nest. If the hole be visited during incubation the sitting bird will utter a peculiar hissing noise, and at the same time twist her neck in a most surprising manner. This habit, which is well calculated to make the observer believe the hole to be tenanted by a snake, has given rise to the name of "Snake-bird" as well as the better-known one of Wryneck. The sexes are alike in plumage, the general colour being greyish with dark streaks of brownish black on the nape and scapulars. Throat, upper breast, and flanks yellowish, becoming paler on the belly, with narrow black bars and arrow markings. The young are greyer, and have no yellow or arrow-shaped markings on the under parts. Length 7 in.; wing 3.4 in.

Towards the end of September it takes its departure, but some individuals frequently remain much later, and probably occasionally spend the winter with us. 




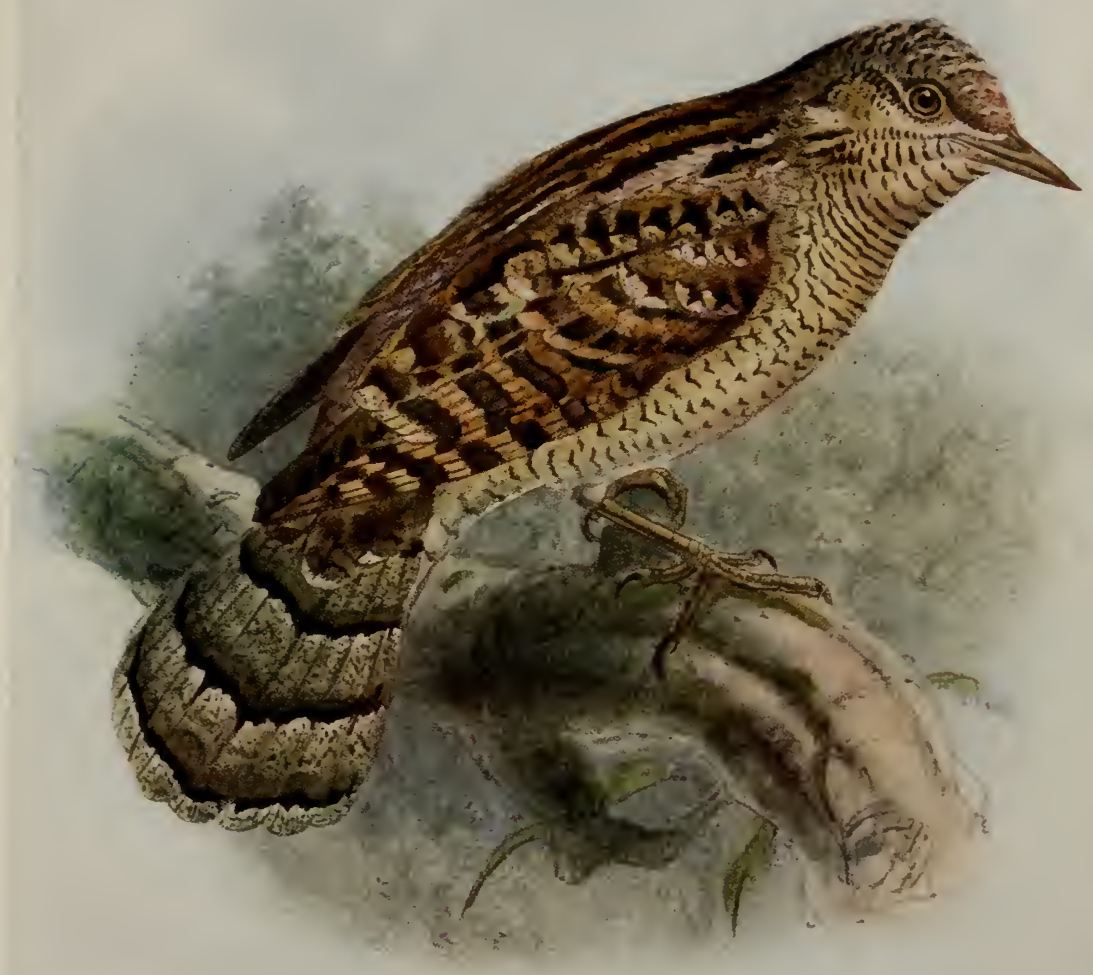





\section{The Green Woodpecker}

\section{THE GREEN WOODPECKER}

\section{Gecinus viridis (Linnæus)}

The cheery "pleu, pleu, pleu" of the Yaffle as it flies from one tree to another may be heard in most parts of England and Wales, though in Scotland and Ireland it is almost unknown. It is a moderate-sized and somewhat ungainly bird in its actions, spending its life among trees, though it by no means restricts itself to woods, especially in autumn, when it may frequently be seen ascending some hedgerow tree, with its characteristic jerking motion, the stiff and pointed tail feathers aiding it to cling to the trunk. Its food consists of insects, more especially beetles and ants, which it finds in crevices of the bark, but it often descends to the ground in search of food.

Its flight is direct and undulating, and it proceeds by a series of rapid wing-beats followed by a short falling period, when the wings are half closed. On the ground it progresses by short hops, and when searching a tree for food, it ascends spirally from the base in short jerks, flying off when near the top to recommence its search at the base of another. Early in April it begins to excavate a nesting-hole, choosing for preference a tree destitute of lower branches. A neat circular hole is chiselled out, which is carried in horizontally for some distance, and then turns downwards. No special nest is made, the glossy white eggs, about five in number, being laid on the bare wood.

The young remain in the nest till they are full fledged, and then scatter to earn their own living. 


\section{Birds of Britain}

The general colour of the male is olive green, shading into yellow on the rump and becoming greyer on the under parts. The crown and nape are crimson, and there is a malar stripe of the same colour edged with black. The female has less crimson on the head and the malar stripes are black. The young are mottled on the back and spotted on the under parts with blackish. Length 12.5 in.; wing 6.4 in.

\section{THE GREATER SPOTTED WOODPECKER}

\section{Dendrocopus major (Linnæus)}

Although it can nowhere be called abundant, this species is widely distributed in well-wooded districts as far north as Durham, but in Scotland it is a scarce bird, only nesting very sparingly in the south, and in Ireland it is almost unknown. A quiet and shy bird, it is rarely seen, keeping as it does to the higher branches of tall trees, and when possible keeping the trunk between it and any would-be observer. In its food and habits it resembles the Green Woodpecker, though it is comparatively seldom seen on the ground. The call-note is a sharp, short "chik," but it makes also a peculiar rattling sound by rapping its beak against a bough. This sound, which is more often heard in early spring, has been supposed to be made only at that season, but it may also be heard, though less frequently, at other times of the year.

In winter this species is much given to wandering, and every autumn our local birds receive further additions from I 80 




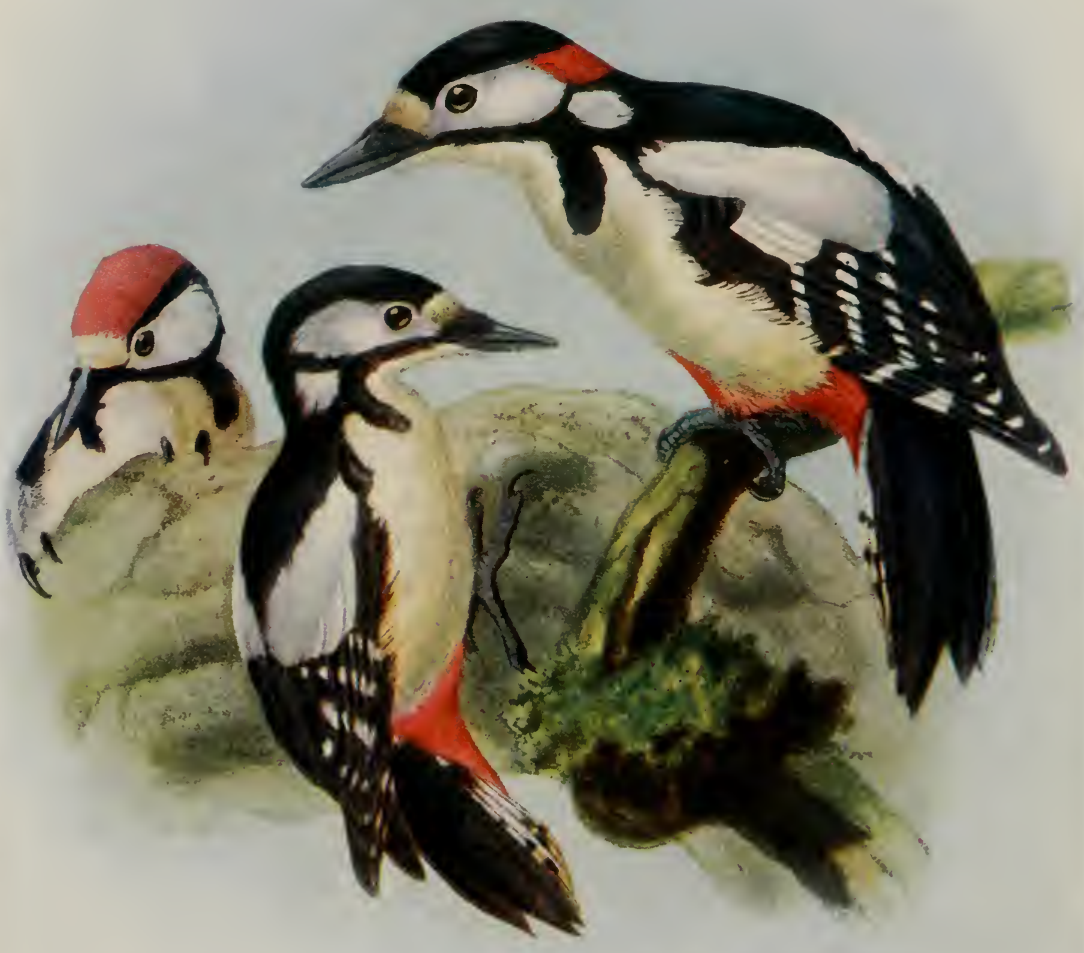





\section{The Great Spotted Woodpecker}

Scandinavia. It can hardly, however, be considered a regular winter visitor, as such immigrations are largely dependent ou the season, and it is only at irregular periods that really large numbers arrive.

The upper parts of the male are chiefly black; the forehead, cheeks, ear coverts, and scapulars are white; nape crimson; wing feathers black, barred with white on the outer webs; under parts whitish; vent crimson. The female lacks the red on the head, but the young of both sexes have the crown red. Length $9 \cdot 4$ in.; wing 5.5 in.

\section{LESSER SPOTTED WOODPECKER}

\section{Dendrocopus minor (Linnæus)}

In many well-wooded localities in the south, the Lesser Spotted Woodpecker may be almost considered common, though from its small size and partiality to the topmost branches of tall trees, it is but seldom seen. In Wales and north of the Midlands it becomes extremely local, and in Scotland and Ireland it has only been obtained as a rare straggler on a few isolated occasions. In food and habits it hardly differs from its larger congener, but the nest is generally hewn out in some dead tree. It has not occurred on migration. The male has the upper parts chiefly black, barred with white; the forehead buff; crown of the head crimson; nape and malar stripe black; cheeks white. The under parts are buffish white with black streaks on the flanks. The female has only got a little red on the fore part of the head. Length 6 in.; wing $3 \cdot 7$ in. 


\section{Birds of Britain}

\section{THE KINGFISHER}

\section{Alcedo ispida, Linnæus}

In spite of the ease with which he may be caught, and the demand for his skin brought about by his fatal beauty, we are still able to reckon the Kingfisher as a generally distributed species.

Representative of a family which is essentially associated with tropical climes, he still wears his brilliant dress in these northern latitudes, and resembles, as he darts with rapid flight down our rivers and streams, some huge turquoise.

Having fixed on a favourite piece of water, he seldom wanders far afield, but may be seen at all times of the year, sitting on an overhanging bough, ever and anon dropping into the water to seize some passing' fish. His prey being captured, he returns to his perch and kills the struggling fish by knocking it against his stand; it is then swallowed head first, and he resumes his motionless watch. If sport be slow, and he be hungry, he will wend his way with rapid flight down the river to try his luck in another place, and it is at such times that we shall probably get a momentary glimpse of his brilliancy, till a curve in the stream hides him from sight.

Mere cold does not seem to affect him in the least, but when the streams are frozen he suffers greatly from hunger, and after a day or two of frosty weather he reluctantly leaves his accustomed home for the milder reaches of the 182 

KINGFISHER

Alcedo ispida 


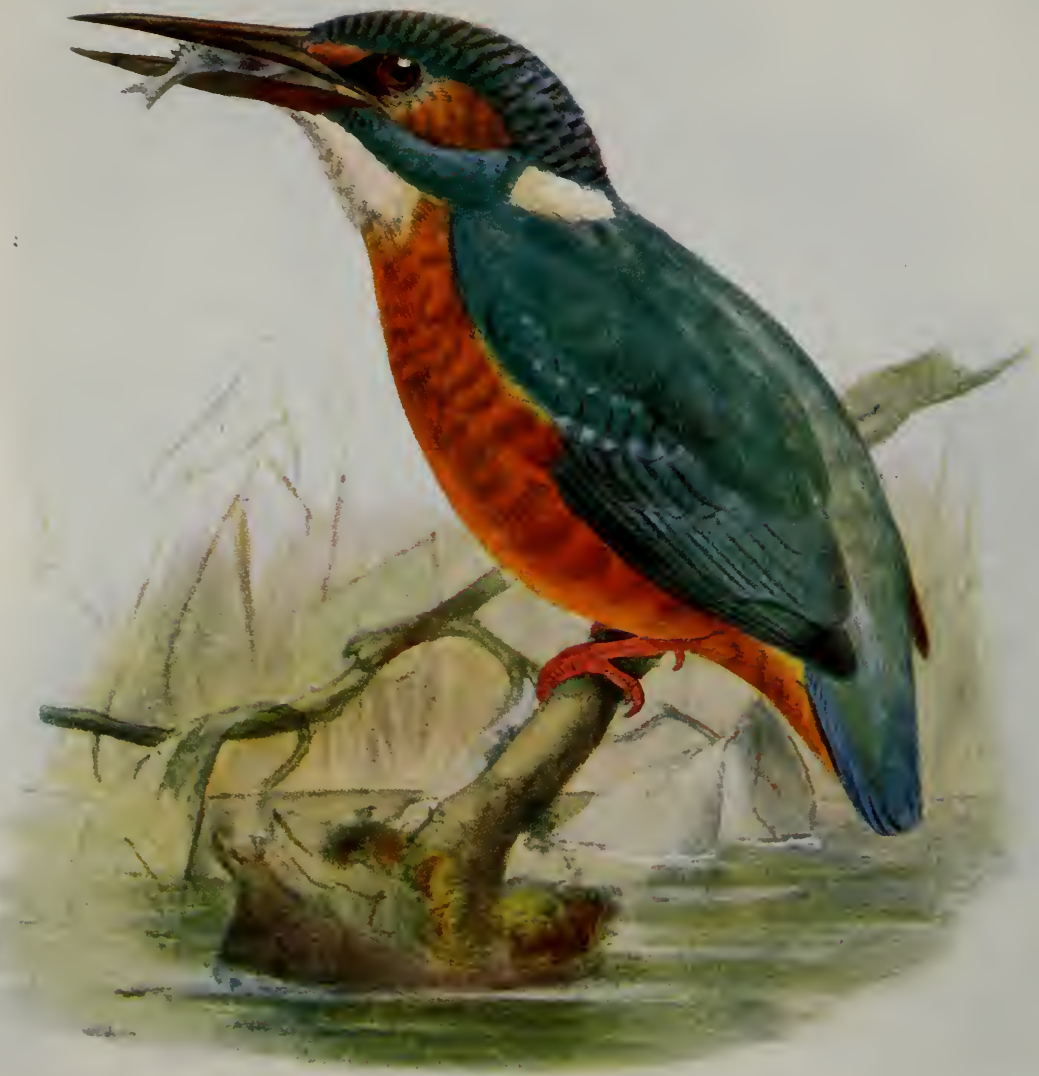





\section{The Kingfisher}

sea-shore, where the restless tide brings him in a continual supply of food. The sea-shore, however, is not to his taste, and at the first break-up of the frost he returns again to his inhospitable home. Early in April he turns his attention to housekeeping. Like most bright-plumaged birds, he has no song with which to woo his mate, but at such times they may often be seen chasing each other about up and down the stream, uttering their shrill and sharp call-note. A perpendicular wall in the bank of the river is chosen, and near the top of this they excavate a long low tunnel with the end slightly widened out to form a chamber. The nest is peculiar, being formed of a mass of small regurgitated bones, and on this the six pure white and highly glossed eggs are laid. As soon as the young are fledged and thoroughly able to earn their own living, they are driven away from their home and forced to seek winter-quarters elsewhere. Many, especially in the northern portions of its range, go to the sea-shore and migrate, while others seek out some quiet stream where they may fish in undisputed possession, till the return of spring impels them to seek a mate and form a home for themselves. The sexes are practically alike in plumage. The top of the head, wings, and malar stripe are dark greenish blue, mottled with lighter; back and rump brilliant cobalt blue; tail dark blue. The under parts, lores, and ear coverts are chestnut; throat whitish; bill black, orange at the base; legs deep red. The young bird is duller and shows traces of greenish on the breast. Length $7 \cdot 5$ in.; wing 3 in. 


\section{Birds of Britain}

\section{THE ROLLER}

\section{Coracias garrulus, Linnæus}

Although stragglers of this beautiful and brilliant species have frequently visited this country in both the spring and autumn migrations, it can by no means be considered as a regular visitor to our shores. It is very numerous in Southern Europe and breeds as far north as St. Petersburg and certain parts of Sweden; in the countries bordering the North Sea, however, it is decidedly rare. In winter it inhabits the southern portion of Africa, being numerous in Cape Colony and Natal.

The sexes are alike. The head, neck, and under parts are of a brilliant greenish blue, the mantle is brown, and there is a patch of gorgeous ultramarine blue on the lesser wing coverts. Length 12 in.; wing $7 \cdot 7$ in.

\section{THE BEE-EATER}

\section{Merops apiaster, Linnæus}

A good many stragglers of this southern species have occurred from time to time, chiefly in the southern half of England, but a few have also been taken in Scotland and Ireland. In Southern Europe it is extremely abundant throughout the summer, wintering in Africa. The sexes are alike. The head, neck, upper back, and a bar across the secondaries are chestnut brown; forehead white, turning to 


\section{The Bee-Eater}

green; lores and ear coverts black; tail green, two central feathers elongated and tipped with black. Throat yellow; a black band across the lower neck; under parts greenish blue. Length 11.25 in.; wing 6 in.

\section{HOOPOE}

\section{Upupa epops, Linnæus}

In the spring of every year, with unfailing regularity, a few misguided individuals of this interesting bird seek the hospitality of our shores, and, were they unmolested, would eventually settle as one of our permanent summer visitors in the southern counties. Unfortunately, apart from its striking plumage, which cannot fail to arrest attention, it is of a very confiding nature, stalking about lawns and grass fields with its peculiar walk, while it prods the ground with its long bill in search of grubs and insects. Such a sight is too much for the so-called collector or ignorant loafer, whose only idea on seeing a strange bird is to kill it, and thus it happens that our would-be guest either reposes as a fearful caricature in a glass case till moth and rust have done their work, or is frightened off to some other country where his appearance excites less curiosity and murder. From time to time, however, protected by some enlightened farmer or landowner, this species has been spared to pass the summer unmolested, and, choosing a hollow tree, preferably in an orchard or near some open grass fields, has reared a young brood to 


\section{Birds of Britain}

maturity and finally departed in peace to spend the winter in Southern Europe or Africa.

The nest is placed in a hole in some tree, and the eggs, seven in number, are of a uniform pale greenish blue.

General colour of the head, mantle, and under parts pale cinnamon; wings and tail black, broadly barred with white. Lower back broadly barred with black, white, and buff. The sexes and young resemble each other in plumage. Length 12.2 in.; bill 2.5 in.; wing 6 in.

\section{THE CUCKOO}

\section{Cuculus canorus, Linnæus}

The arrival of the Cuckoo, as heralded by his well-known note, is eagerly awaited by every one who lives in the country, ornithologist or otherwise, and so anxious are some to record his arrival, that they persuade themselves that they have heard him before the March winds have abated. There is little doubt, however, that this species rarely, if ever, arrives in March, and not before mid-April can his pleasing note be generally heard. Throughout the whole of our islands this bird is common and well known, inhabiting equally the wild open country, the enclosed arable land, or thickly-wooded estates. It feeds entirely on insects, especially caterpillars, those of the common Tiger-moth being an especially favourite delicacy. Its flight is direct and fairly rapid, the short wings and long tail giving it very much the appearance of a Sparrow-Hawk, for which it is I 86 

CUCKOO

Cuculus canopus

Adult (below). Young (above) 


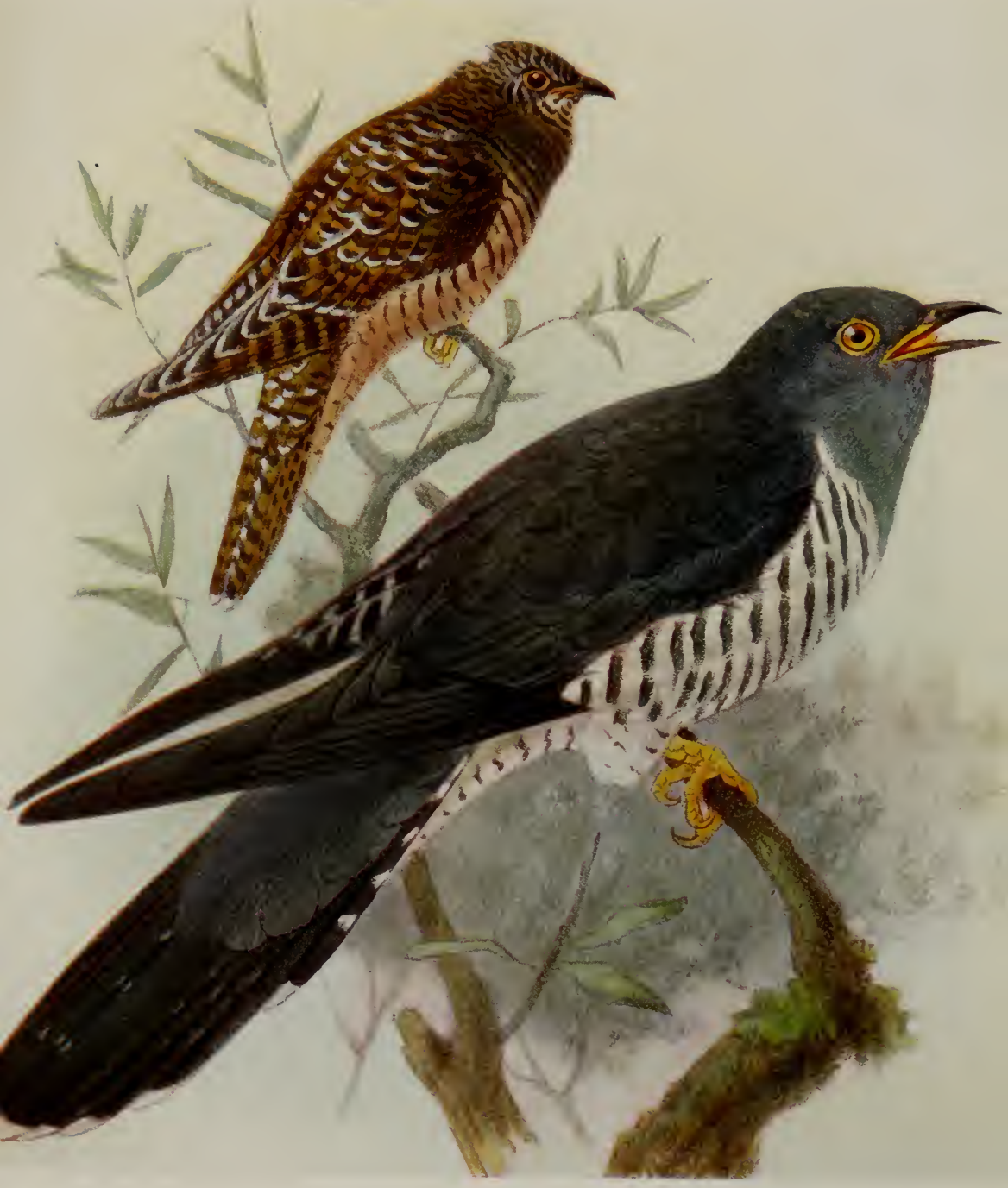





\section{The Cuckoo}

frequently mistaken by the smaller birds, and mobbed accordingly.

This bird solves housekeeping difficulties in the simplest way by leaving its eggs to the tender mercies of other species. It apparently usually watches other birds when building, and as soon as the chosen nest contains a few eggs, it lays its own egg on the ground, and picking it up in its beak deposits it in the nest, throwing out at the same time a few of the rightful eggs. The eggs are, as a rule, deposited one by one in a different nest of the same species, and when two Cuckoo's eggs are found in the same nest, they are almost assuredly the produce of two different birds. Having deposited its eggs, the mother Cuckoo takes no further interest in her progeny, but continues to lead a life of leisure, till early in August both sexes leave us for their southern winter-quarters. The eggs of this species are extremely variable, but as a rule are of a pale bluish or greenish ground colour, with reddish spots and mottlings; sometimes they agree so closely with the eggs of their foster-parents as to be almost indistinguishable, but such cases are exceptional. When the young Cuckoo has been hatched about twenty-four hours, he sets to work to eject the other nestlings by getting them on his back, in which there is a hollow, and pushing them over the side of the nest. He is most importunate in his demands for food, and continues to be a burden on the foster-parents long after he is able to feed himself. Once, however, he is fledged, he wings his way southwards and we see him no more, till he returns the following spring to gladden us with his cheering "cuckoo." Various species of insectiI 87 


\section{Birds of Britain}

vorous birds are made use of as foster-parents, and there is no doubt that much discrimination is exercised by the mother Cuckoo as to where and when to deposit her egg. The nests most favoured in this country are those of the Meadow Pipit, Pied Wagtail, Hedge Sparrow, Sedge and Reed Warblers, but over sixty different species of British Birds have been made use of at various times. Practically nothing is known as to whether Cuckoos pair, or if the female receives the attentions of several males, and the number of eggs laid by a single bird in the season is also donbtful, though about eight is said to be the number. Many interesting problems are thus still unsolved about one of our commonest birds, and if his character be not a very estimable one, we can but marvel at the workings of evolution which has enabled so curious and complicated a method of parasitism to be sufficiently successful to ensure the perpetuation of the race. It must be remembered that for the successful rearing of each young Cuckoo the mother has to find and recognise the nest of an insectivorous bird, and to lay her egg during the five days in which the foster-parent elect is laying her clutch. As regards the various stages of evolution that have caused the young Cuckoo to evolve as a murderer at his birth, and that have provided him with the means in the shape of a special hollow in his back, we know nothing, and can in the present state of our knowledge merely leave the problem in wonder and amazement.

The male is clear greyish ash on the back and throat; tail feathers blackish with small white spots on the margin. Under parts whitish, with dark bars on the flanks. The I 88 


\section{The Cuckoo}

young vary considerably and are generally dark brown, more or less barred with rufous on the upper parts. Length 13 in.; wing 8.5 in.

\section{THE GREAT SPOTTED CUCKOO}

\section{Coccystes glandarius (Linnæus)}

On three or four occasions this bird has been obtained in England and Ireland. It is a native of North Africa and South Spain, where it breeds, migrating in winter to South Africa. Its eggs are almost always deposited in the nest of a Magpie, but other members of the Crow family are sometimes chosen. The general colour is greyish brown, most of the feathers tipped with white; under parts white. The crown is grey, with long pointed crest. Length 15.5 in.; wing 8 in.

\section{THE AMERICAN YELLOW-BILLED CUCKOO}

\section{Coccyzus americanus (Linnæus)}

Some half-dozen examples of this American species have occurred on our western shores during the autumn migration. It is about the size of our Cuckoo, olive-brown above, and buffish white below. Each of the tail feathers are tipped with white. Length 11 in.; tail 6 in.; wing 5.40 in. 


\section{Birds of Britain}

\section{THE BARN OWL}

\section{Strix flammea, Linnæus}

After many years' patient preaching, the Barn Owl is at last beginning to be recognised as a friend to be encouraged, rather than as an enemy to be slain, and it is now on the increase throughout England, Wales, and Ireland. In Scotland it has always been local in the south and rare in the north.

The species is strictly nocturnal, and darkness has usually fallen before it sallies forth from its hiding-place in a barn, an old church tower, or a hollow tree.

It feeds almost entirely on rats, mice, and such small deer, and rarely takes any small birds, as they are always securely roosting by the time the Barn Owl comes out. From its habits of choosing barns and old buildings, this species more than any other is deserving of man's protection, since its favourite hunting-grounds are round the farm-yards, where it destroys those vermin that are of most immediate nuisance to the farmer.

The note is a harsh high-pitched scream, which has earned for it the name of "Screech Owl," but when in its hole it makes a heavy snoring sound, and has also a curious habit of waving its head from side to side. When seen from above down a dark hole, the motion being just dimly visible, it has a very uncanny appearance.

The eggs, oval in shape and pure white like those of all Owls, are laid without any attempt at a nest. They are 




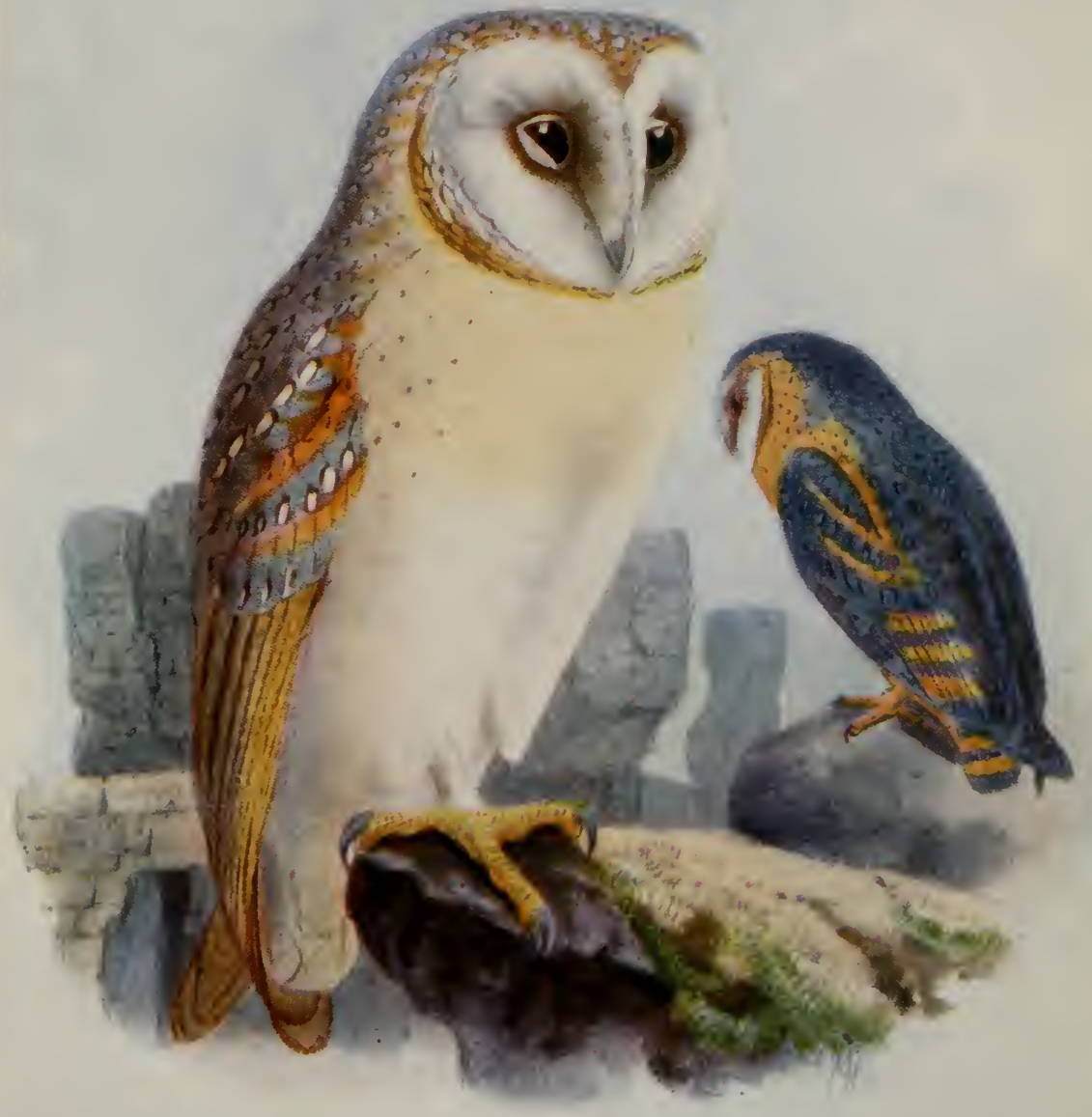





\section{The Barn Owl}

generally laid in clutches of two, at intervals of some days, so that four or six young of varying ages are generally found in the nest together. Unlike most of the other Owls, the first plumage of the young is composed of true feathers, whereas in most of the other species the young are at first clothed, with the exception of the wings and tail, in a plumage of downy feathers, which after being worn for a short time is exchanged for the full plumage.

The general colour above is buffish orange, minutely speckled and vermiculated with grey. The under parts are white, sometimes slightly buffish on the chest, and with a few minute black specks. The sexes are alike, but the female is said to be more speckled on the under parts. The young resemble the adults. Length 13.5 in.; wing $11 \cdot 25$ in.

\section{THE LONG-EARED OWL}

\section{Asio otus (Linnæus)}

Though it is distinctly commoner in Scotland, this species is not rare in any of the wooded districts of our islands. It is very partial to fir woods or evergreen plantations, and early in the year takes possession of an old nest or squirrel's drey in which to deposit its six white eggs. The young are chiefly fed on rats and mice, but moths and beetles are also eaten with relish, while small birds are not despised. The daytime is spent among the branches of the trees, and when alarmed by any noise the bird draws itself up and leans against the trunk of the tree, in which position it may 


\section{Birds of Britain}

easily be overlooked. It flies out at dusk and ranges the fields near woods for its prey.

In the northern parts of Scotland it is a regular migrant, but elsewhere within these islands it is resident, though immigrations from the Continent occur every year. It is a very silent bird, but occasionally gives rise to a short mellow bark.

The sexes resemble each other and are buffish, heavily speckled and vermiculated with dark brown, ashy, and white. The markings of the young are yellowish, and warmer in tint. The name is derived from two longish tufts of feathers above the facial disc, which can be erected at will. Length 14 in.; wing 11.5 in.

\section{THE SHORT-EARED OWL}

\section{Asio accipitrinus (Pallas)}

Unlike the preceding species, this bird inhabits fens, marshes, and open moorlands. In Scotland it nests fairly commonly, but in England it is decidedly rare and local as. a breeding species, while it has never been known to breed in Ireland.

The nest is placed on the ground, at the foot of a small bush in long sedge, or among heather. No real nest is made, but a few bits of grass or heather are arranged round the eggs. These are usually five in number, and, like all Owls' eggs, pure white. In some seasons these Owls become much more abundant in certain places, due generally 

LONG-EARED OWL

Asio otus 


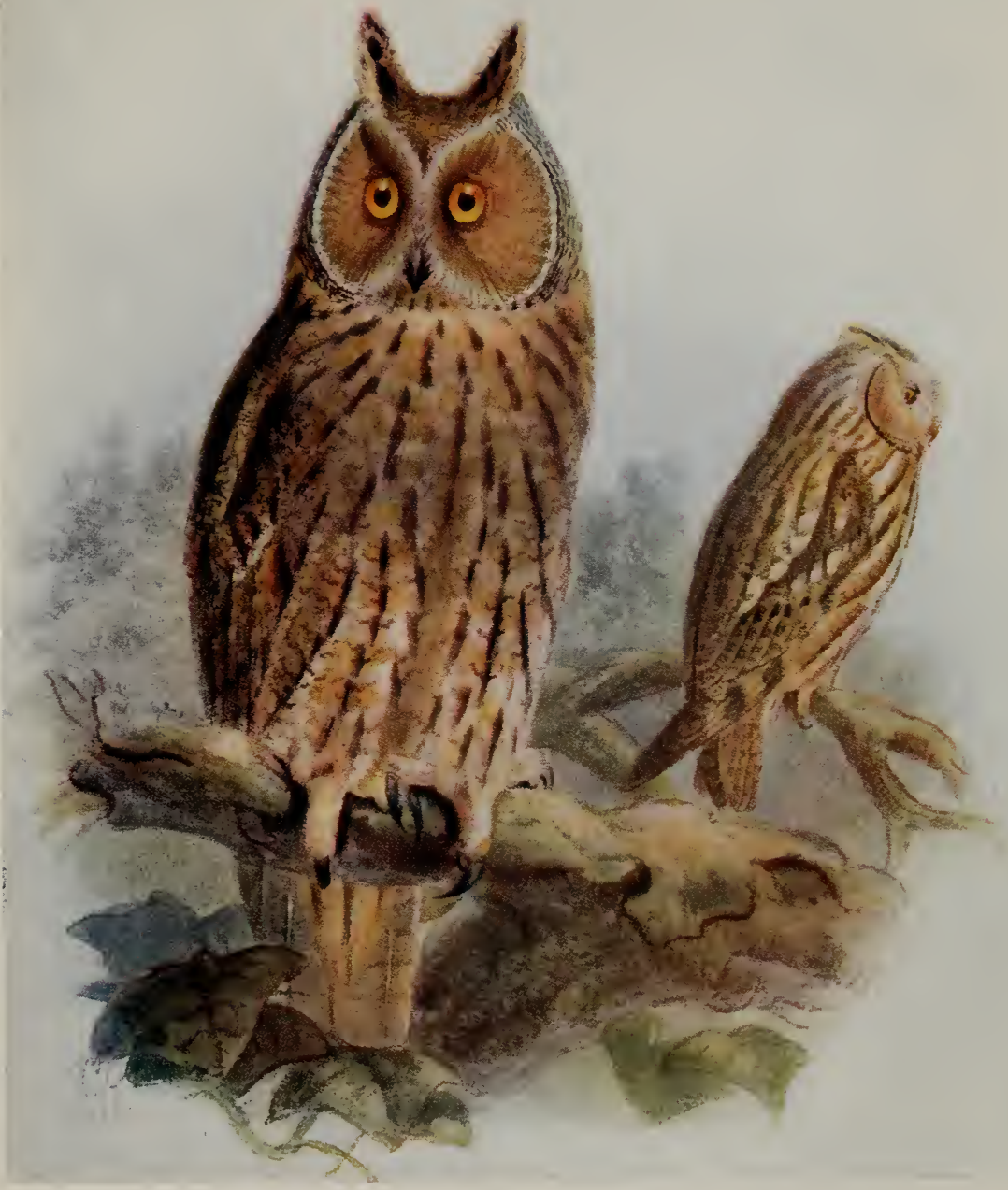





\section{The Short-eared Owl}

to a great increase in their food, which consists almost entirely of field-voles. In the years when these voles increase to an enormous extent, this species will also appear nesting in considerable numbers, where it was almost unknown before, and in such seasons as many as twelve eggs have been found in a clutch. It is by no means a nocturnal bird but takes its food by day, and may thus be easily noticed on its approach in a new locality. The flight is somewhat heavy and uncertain, frequently twisting about and rolling from side to side.

In autumn, large immigrations reach this country from abroad, and during the winter it becomes quite common in suitable places throughout England and Ireland. $\mathrm{He}$ is frequently flushed from the turnip-fields in October, and is for this reason known in some places as the "Woodcock Owl."

In plumage it resembles the preceding species, but the markings are bolder and the delicate grey vermiculations are entirely absent. The ear tufts are much shorter. Length 14.5 in.; wing 12 in.

\section{TAWNY OWL}

\section{Syrnium aluco (Linnæus)}

The Tawny Owl is a common inhabitant of the wellwooded parts of England, Wales, and Scotland, though in the north of the last-named country it becomes decidedly scarce and local. In Ireland it has not yet been obtained. 


\section{Birds of Britain}

It nests early in March, the eggs being usually placed in a hollow tree, though it often makes use of deserted nests of Rooks, Crows, or Hawks, and sometimes nests on the ground at the base of a tree. The eggs are white and glossy and much rounder in shape than those of the Barn Owl. It is extremely nocturnal, never appearing till quite dark, and seldom pursuing its prey in the open, but keeping to glades and rides in the woods. Its hoot is a loud "hoo hoo," and is repeated with great frequency. This species is never met with on migration, but is one of the most resident of birds, rarely wandering far from its birthplace.

The sexes are alike, except that the female is slightly larger. The general colour is usually of a warm tawny brown, mottled and streaked with darker shades of the same colour; the under parts are pale buffish white, striped with dark brown. There are two phases of this species which are alike in markings, but in one the predominating tint is red and in the other grey. Length 15 in.; wing 10 in.

\section{TENGMALM'S OWL}

\section{Nyctala tengmalmi (J. F. Gmelin)}

This species is an inhabitant of the pine forests of Northern Europe, migrating southwards in winter. A few stragglers have occurred in these islands from time to time. The general colour above is umber brown, spotted and marked with white; the facial disk is white with a dark 


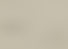


- TAWNY OWL

Syrnium aluco 


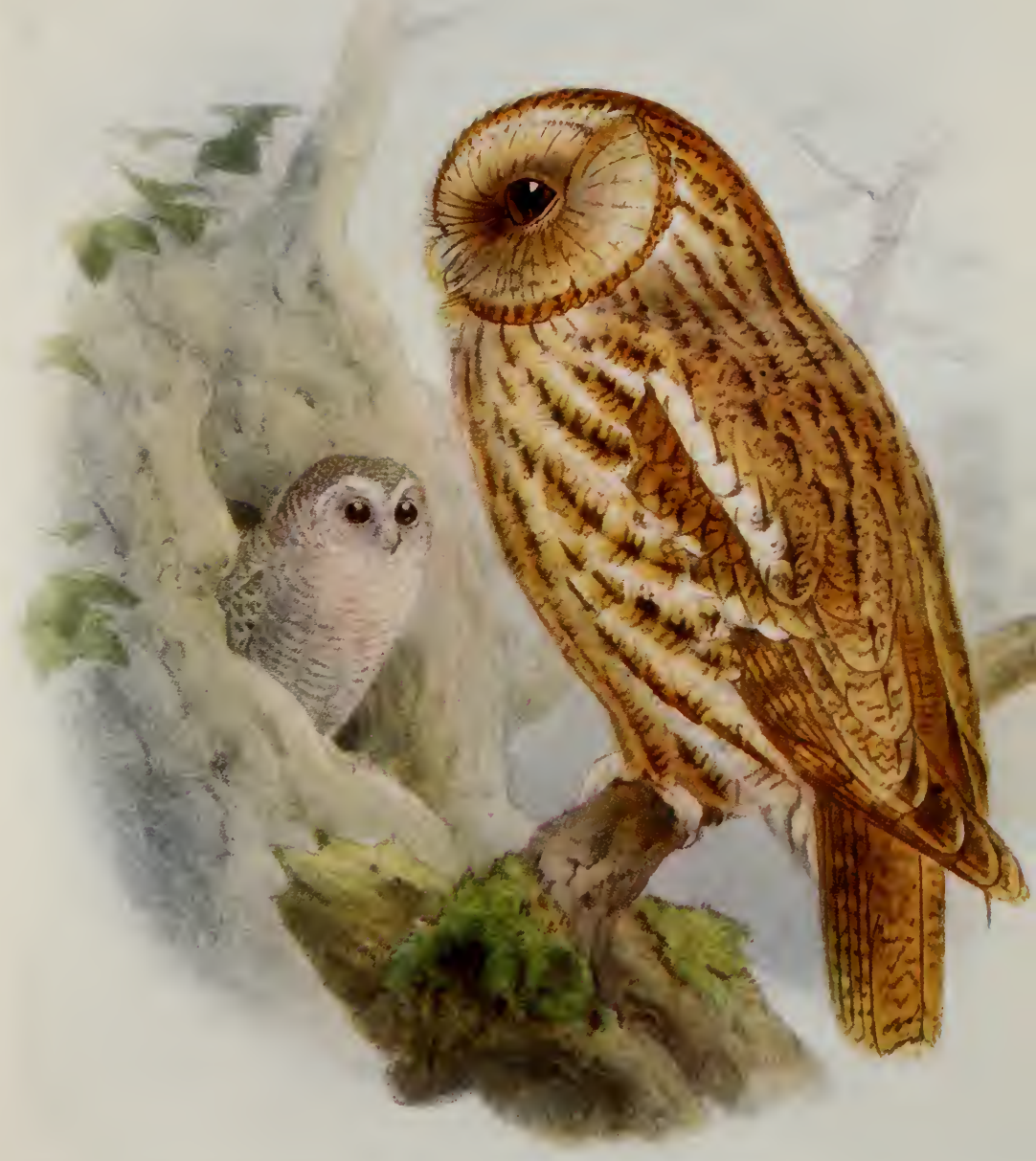





\section{Tengmalm's Owl}

outer ring; under parts whitish, barred and streaked with brown. Length 9 in.; wing 6.5 in.

The plumage of this species is exceptionally thick and downy; the feathers on the legs and toes especially so.

\section{THE LITTLE OWL}

\section{Athene noctua (Scopoli)}

This bird has undoubtedly occurred on many occasions as a straggler in this country, but its claim as a British Bird now rests on introductions which have been made in Kent, Northampton, Bedford, Yorkshire, and other places where it has more or less established itself as a breeding species, and is slowly extending its range from at least one of these centres. It is a small species, living chiefly on insects and mice, and is generally found in well-wooded country, where it may be often seen sitting on a dead tree or post, sunning itself, for it is largely diurnal in its habits.

The plumage above is a warm brown spotted with white; under parts white striped with brown. The female is rather larger than the male. Length about 9 in.; wing 6 in.

In this species the feathers on the legs and toes are quite short, being little more than bristles on the latter, a point by which it may be easily distinguished from the preceding species. 


\section{Birds of Britain}

\section{THE SNOWY OWL}

\section{Nyctea scandiaca (Linnæus)}

The Arctic regions both in summer and winter form the home of this large and handsome species, though many wander southwards during the winter months.

In the Shetlands and Orkneys it is a fairly regular winter visitor during severe weather, and it has frequently occurred in Scotland; to England and Ireland, however, its visits are few and far between.

The plumage is pure white, spotted and barred with dark brown, the amount of which varies greatly in individuals. Length of male $22 \mathrm{in}$; wing 15.5 in. The female is slightly larger.

\section{THE HAWK OWL}

\section{Surnia funerea (Linnæus)}

The Hawk Owl inhabits the pine forests of Northern Europe, Siberia, and North America. It has occurred here as a straggler on several occasions, the majority of examples having been shot in the western counties of England and Scotland, and belonging curiously enough to the American race, which has the bars of the under parts more ruddy than the European form. This latter form has, however, also been obtained on at least one occasion. 


\section{The Hawk Owl}

The upper parts are brown, spotted with white; under parts white barred with greyish or reddish brown. Its most characteristic feature is the tail, which is long and graduated, barred and tipped with white. Length about 15 in.; tail 7.5 in.; wing 9.2 in.

\section{THE SCOPS OWL}

\section{Scops giu (Scopoli)}

A migratory species, wintering in Abyssinia and Northern Africa, and breeding in Southern Europe, the Scops Owl has occurred as a straggler to our islands a good many times. The general colour is grey, barred and vermiculated with brown; it has two conspicuous ear tufts. The female slightly exceeds the male in size. Length, male, $7 \cdot 5$ in.; wing $5.8 \mathrm{in}$.

\section{THE EAGLE OWL}

\section{Bubo ignavus, T. Forster}

This large and fine species has been obtained several times in England and Scotland, but though some of the instances are undoubtedly those of genuine wanderers, it is so often kept in captivity that several occurrences must be looked upon as those of escaped birds.

It is widely distributed throughout the wilder districts of Europe, both in forest and open country, from Scandinavia to the Mediterranean. 


\section{Birds of Britain}

The general colour is dark brown, mottled with brownish buff above, and yellowish brown streaked with darker below. The female is larger than the male. Length of male $24 \mathrm{in}$; wing $18 \mathrm{in}$.

\section{THE GRIFFON VULTURE}

\section{Gyps fulvus (J. F. Gmelin)}

A single immature example of this species was taken in the spring of 1843, in Cork Harbour. The nearest breeding place of this species is in the Pyrenees, and thence eastwards it occurs throughout Southern Europe. The sexes are alike and their general colour is buffish brown; the head and neck are devoid of feathers but covered with buffish down, which is separated from the feathers of the neck by a broad ruff. Length 42 in.; wing 28 in.

\section{THE EGYPTIAN VULTURE}

\section{Neophron percnopterus (Linnæus)}

This is another South European species of which two examples have been obtained, one in Somersetshire and one in Essex.

The adult is white with black primaries, the head and neck being bare of feathers and yellow in colour. The young bird is dark brown and does not acquire its full plumage for three years. Length 26 in.; wing 19 in. 


\section{The Marsh Harrier}

\section{THE MARSH HARRIER}

\section{Circus æruginosus (Linnæus)}

Formerly this species used to breed regularly in many places in England, where large stretches of marsh-land suitable to its habits were to be found. A pair or two may occasionally still try to rear a brood in East Anglia, but owing to the drainage of the fens, it is no longer known in any of its former haunts. In Ireland, where it was formerly fairly common, its breeding area is restricted to one locality. To Scotland it has always been an extremely rare visitor. On migration small numbers of this species visit England and Wales yearly. The nest is a fairly substantial structure, built of reeds and grass, and placed on the ground. The eggs, which generally number five, are pale bluish white without any other markings.

In plumage this species varies greatly according to age; the adult male is dark brown on the back, head creamy white with dark streaks, wing coverts and tail silvery grey; primaries blackish. Under parts buff streaked with brown. In the female the tail and under parts are brown. Young birds are chocolate brown; the entire crown of the head is buffish white in the males, but in the females the nape only is yellowish. Length (of males) $21 \mathrm{in}$; wing $16 \mathrm{in.}$ 


\section{Birds of Britain}

\section{THE HEN HARRIER}

\section{Circus cyaneus (Linnæus)}

In England, thanks to the game-preserver, this species is now extremely scarce, and very few pairs, if any, are allowed to nest. In Scotland and Ireland, where it was formerly fairly plentiful, it is fast decreasing in numbers. On migration it is still not uncommon in the north, and the passage of stragglers through England is of yearly occurrence, but very few remain to spend the winter in any part of this country. It frequents large open moorlands, which, like all Harriers, it regularly quarters in its search for food. This consists of young birds, rats, mice, and frogs or lizards. The nest is made of roots, heather, and plant stems, and the eggs are bluish white, often faintly spotted with reddish brown.

The adult male is slate grey with white rump and white under parts, the throat and breast being bluish grey. The female and young are brown above with the exception of the rump, which is white; tail brown with five dark bars, whence the name "Ring Hawk," which is applied to the females and young of this species. Length 21 in.; wing 15 in.

\section{MONTAGU'S HARRIER}

\section{Circus cineraceus (Montagu)}

Although the commonest of our British Harriers, this species is nevertheless exceedingly scarce and local. It is a 200 


\section{Montagu's Harrier}

migrant, arriving towards the middle of April, and in some of the open moorlands and fenny localities in the south and south-east of England a few pairs yearly attempt to breed.

The sight of this grand bird, as it quarters the ground backwards and forwards in search of food, is an exquisite pleasure to the true naturalist, but in spite of the protection afforded by law, it is ruthlessly destroyed, either by the gamekeeper or the collector of British killed specimens, whenever seen. In habits it closely resembles the Hen Harrier. It nests on the ground, and its bluish white eggs are, as in the case of that species, often speckled with rusty red.

The upper parts, throat, and breast of the male are slaty grey; the hinder parts white, streaked with rufous on the flanks. Tail feathers greyish with five rusty red bars on all except the middle pair. The female, who is slightly larger than the male, is brown above and buff streaked with rufous below. The young resemble the female but are much darker below. Length about 18 in.; wing 15.4 in.

To Scotland and Ireland this bird is only a very rare straggler.

\section{THE COMMON BUZZARD}

\section{Buteo vulgaris, Leach}

Years ago this species might fairly have been called common in our islands, but the gamekeeper, who has much 


\section{Birds of Britain}

to answer for in the extirpation of many species, has not failed to wage war on this beautiful bird. If we still want to see him, as he soars round in graceful curves over his forest home, we shall have to journey to the wilder parts of Wales and Scotland, where alone he is still able to hold his own. Over the rest of our islands he is, as a breeding species, no longer extant, though every year a few migrants from abroad seek our hospitality, only to be killed by the first keeper that sees them.

The nest is placed either on a ledge of a cliff or in the fork of a tree, and is a bulky structure of sticks, lined and surrounded with fresh leaves, which are continually renewed as they wither. The eggs, four in number, are bluish white, marked with rusty red near their larger end. Both sexes incubate, and if the nest be approached, circle round and round the intruder with piteous "mewing" note. As far as game birds are concerned, this species is practically harmless, feeding almost entirely on ground game, frogs, and reptiles, so that no one can have any excuse for destroying it.

It is a very variable species; the general colour is dark brown above and below with a whitish band showing longitudinal dark stripes on the breast, but in some individuals there is very much more white. The young bird is usually paler on the upper parts. The female only differs from the male in her slightly larger size. Length about 22 in.; wing $15 \cdot 5$ in. 


\section{The Rough-legged Buzzard}

\section{THE ROUGH-LEGGED BUZZARD}

\section{Buteo lagopus (J. F. Gmelin)}

The Rough-legged Buzzard, which differs from the Common Buzzard in having the legs feathered to the toes, is a regular autumn migrant to this country, especially in the north and east of Scotland. In some years its numbers are much greater than in others, so that for a time it becomes common even down to the south and east of England. In Ireland it has only been noticed on a few rare occasions.

It is a common and numerous species on the Continent, breeding within the limits of the Arctic Circle, and wandering southwards in winter. In habits and appearance, except for the feathered tarsus, it resembles the preceding species. Length about 23 in.; wing $17 \cdot 2$ in.

\section{THE SPOTTED EAGLE}

\section{Aquila maculata (J. F. Gmelin)}

At long intervals stragglers belonging to this species have been taken in these islands, all of them during the last three months of the year.

This species is a summer migrant to Central and Southern Europe, from whence it migrates on the approach of winter to Africa, large numbers passing down the Nile Valley.

The adult is of a warm brown all over, but the young 203 


\section{Birds of Britain}

bird has the feathers of the upper parts tipped with buff, and the lower parts striped with ochreous. Length of male 19 in.; the female is slightly larger.

\section{THE GOLDEN EAGLE}

Aquila chrysaetus (Linnæus)

This magnificent bird has only been preserved to us as a breeding species owing to the strict protection afforded to the deer in the Highlands and some of the outlying islands off the west coast of Scotland. Thanks to this, it is slightly on the increase in some places, though, as it meets with a speedy death should it trespass over a grouse moor, it can never become generally common. It is a truly grand bird to watch as it soars and circles over the few miles of country to which it claims suzerain rights, and eminently worthy of protection as an object of natural beauty.

The eyrie, which is resorted to year after year, is placed on the ledge of a crag or more rarely in a tree. It is a vast accumulation of sticks, to which additions are made every year, and is lined with tufts of grass. The eggs, usually two in number, are bluish white, marked to a greater or lesser extent with reddish brown.

Its food consists chiefly of mountain hares, though it also takes birds, lambs, and occasionally the fawns of the deer; but although it does sometimes take grouse, they do not form its chief food, and certainly the numbers taken are not sufficient to warrant its destruction. 




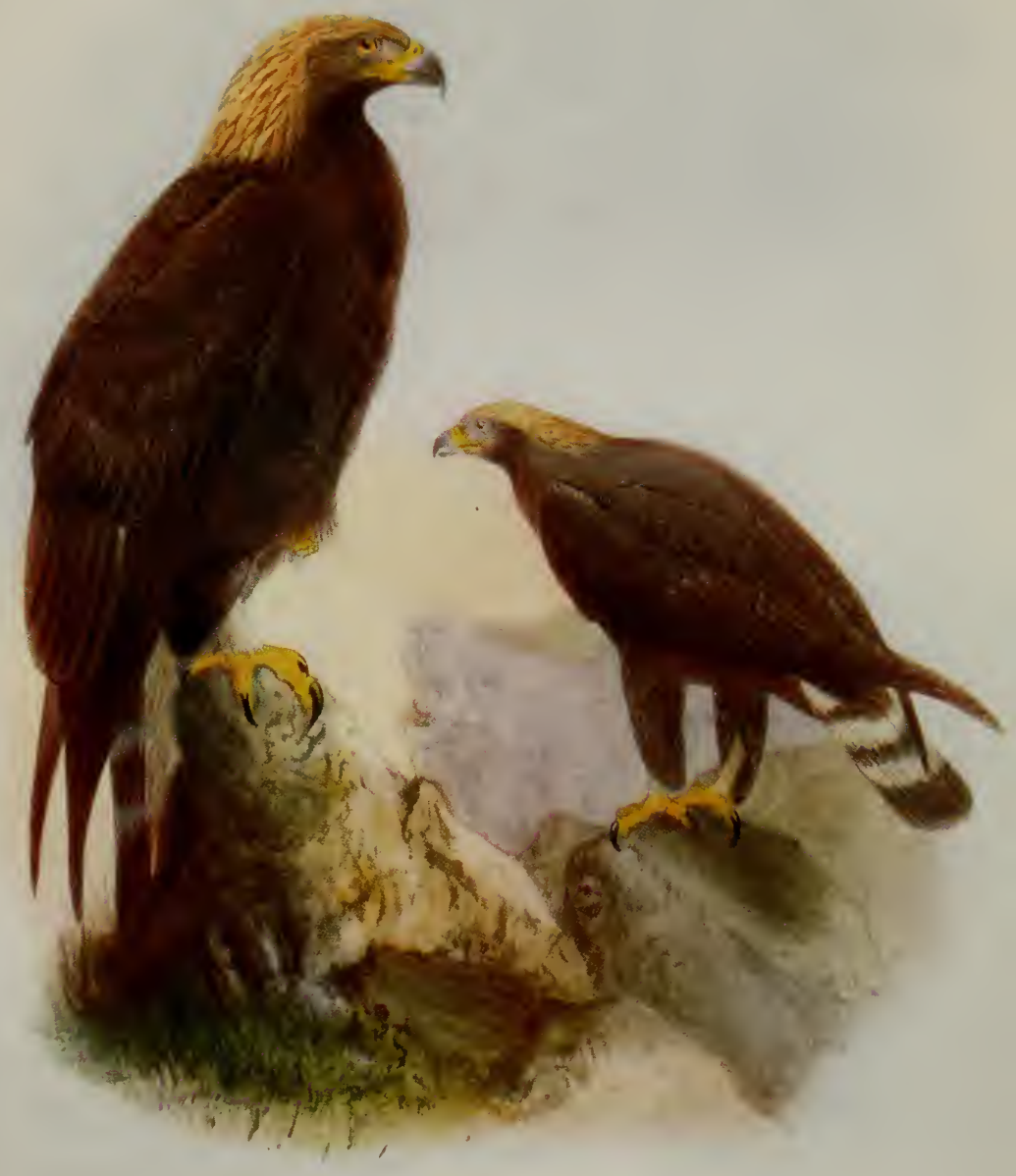





\section{The Golden Eagle}

It does not chase its prey, but having marked them down, pounces on them as they lie.

In Ireland a few pairs still breed in the wilder parts of the north and west, but elsewhere in our islands it is very rarely seen, as it is not given to wandering far from its accustomed haunts. In England it is exceedingly rare, most of the reported occurrences being immature examples of the next species.

The general colour is a uniform dark brown, tawny on the nape. Except in its larger size, the female resembles the male. Young birds may be distinguished by the white bases to the outer tail feathers. Length about 23 in.; wing 24 in.

\section{THE WHITE-TAILED EAGLE}

\section{Haliaetus albicilla (Linnæus)}

This species, which was never common in any part of our islands, is now only found as a breeding bird on a very limited number of stations on the west coast of Ireland and Scotland. In autumn immature birds are frequently observed round our English coasts on their southward migration.

The nest is placed usually on an inaccessible crag by the sea-shore, and is a vast accumulation of sticks and rubbish, which is yearly augmented. The eggs are two in number and dull white without any markings. The habits and food are similar to the Golden Eagle, but it occasionally takes fish, and feeds more readily on carrion. 


\section{Birds of Britain}

Old birds are dark brown with nearly white head and neck and white tail. Immature birds are brown mottled with fulvous on the upper parts and with a brown tail.

This species takes about five years to become adult, and all varieties between these two plumages may be met with. Length about 34 in. ; wing 25 in.

\section{THE GOSHAWK}

\section{Astur palumbarius (Linnæus)}

This species is common throughout the wooded districts of Northern and Central Europe, and has only occurred in these islands at long intervals, almost always on the east coast of Scotland or England. In Ireland it is practically unknown.

In olden times falconers (for this species was in great demand for hawking) used to liberate adults in the spring in order to procure the young when they nested, and in this manner there is no doubt that it became established for several centuries, but it is now over a hundred years since the last English-bred nestling was obtained.

It inhabits wooded districts, and seizes its prey, which consists of both mammals and birds, on the ground.

The adult is brown on the back; the under parts are white barred with dull black. The young is brown above and buff striped with dark brown below.

Length 20 in.; wing 12 in. The female is slightly larger. 


\section{The Sparrow-Hawk}

\section{THE SPARROW-HAWK}

\section{Accipiter nisus (Linnæus)}

Numerous and abundant throughout our woodland districts, it must be confessed that this species, especially when rearing its young, does undoubtedly considerable damage among the pheasant coops, and there is less to be said in favour of this bird than is the case with most of the other birds destroyed by the game-preserver.

Inhabiting woods, it is not so often seen as the windhovering Kestrel, nor is its flight powerful. When hunting, it flies low along a hedgerow or the outskirts of a wood, pouncing suddenly upon any hapless bird that may dart out in front of it. Birds form its principal prey, but it will also take mice, moles, or any other living thing which comes under its notice.

A substantial nest of sticks is built high up in some fir or evergreen. A former nest is often used, sometimes after a lapse of several years. The eggs are extremely handsome, being pale blue with very bold mottlings and markings of deep reddish brown. The same coppice is resorted to yearly, although one of the parents may be shot on the nest and the young destroyed.

The adult male, which is much smaller than the female, is slate blue on the upper parts, with rufous on the cheeks and ear coverts. The under parts are pale buff, barred with reddish brown, some individuals being much redder than others. The female is brown on the back and the under 


\section{Birds of Britain}

parts are whitish, barred with brown. The young, except in size, resemble the female, but the under parts are striped instead of barred.

This species is, however, extremely variable in colour and markings. Length of male 13 in.; wing $7 \cdot 7$ in. Female $15 \cdot 4$ in. ; wing 9 in.

\section{THE KITE \\ Milvus ictinus, Savigny}

Although once so abundant that it used, some two or three centuries ago, to feed on offal in the London streets, the remnant of our indigenous Kites are now reduced to some dozen individuals in the more remote parts of Wales. The gamekeeper, the egg-collector, and even the salmonangler have all combined to destroy this noble species, and even now, when it is far too scarce to do any harm, a vandal has recently shot one of the remnant, and owing to a fault in the administration of the law has got off scot free. It will not be until we have public opinion aroused sufficiently to protect our natural beauties that this ruthless extermination of any rare bird will be stopped. Certain species, e.g. Robin, Thrush, Nightingale, House Martin, etc., are so well protected by that opinion as to become almost too numerous in certain places. The shooting of many of our rarer wanderers can do no great harm if the lust for killing rare birds must be indulged in, but our rare resident or breeding migrants should never be destroyed. We cannot 208 


\section{The Kite}

replace what is thus killed, and these living bits of Nature form a heritage left us by former generations, which it becomes our duty to hand on to the future. For even in the immediate present the delight of seeing the living bird in its native haunts is not confined to ornithologists, but thousands, rich and poor, appreciate intensely the sight of one of our larger and rarer species, amidst its natural surroundings; and no censure can be too strong for the man who wilfully destroys that creature for his own selfish ends, whether for the sake of having its stuffed effigy in a glass case, or that he may bag a larger number of pheasants in due season. It is a crime as great or greater than the stealing of art treasures from our National Gallery.

The wide circling flight of the Kite is a magnificent sight, as it daily covers large tracts of country in search of its food. Offal and carrion are, or should be, the chief diet of this species, but in this country it chiefly subsists on small mammals and birds, becoming, at the nesting time, very bold and taking toll from the poultry-yard and game coverts.

The Kite was formerly common throughout England and by no means rare in Scotland, but for many years past it has been restricted to certain places, in almost all of which it is now extinct. It is only a very occasional wanderer to Ireland.

The nest is placed in a tall tree and composed of sticks, with a lining of any rubbish that can be found. The eggs, three in number, often only two, are pale blue, spotted and streaked with reddish. 


\section{Birds of Britain}

The adult is brown on the back and chestnut below, with darker stripes. Tail rufous and much forked. Head and neck whitish, with darker stripes. Length $25 \mathrm{in.;} \mathrm{wing}$ 20 in.

\section{THE BLACK KITE}

\section{Milvus migrans (Boddaert)}

This species, although a regular summer visitor to the valley of the Rhine and Moselle, has only once found its way to our shores. Its home is throughout Central and Southern Europe, migrating southwards from the more northerly portions of its range in winter.

The head and throat are whitish, streaked with dark brown; rest of the plumage brown, more rufous on the breast. The female is rather darker on the head. Length 24 in. ; wing 18 in.

\section{THE HONEY BUZZARD}

\section{Pernis apivorus (Linnæus)}

This migratory species, which is widely distributed throughout most of the wooded districts of Europe, visits us annually on both its spring and autumn migrations, and a few pairs generally attempt to nest in suitable localities. The greed of the egg-collector has sadly diminished the number of these summer residents, though with adequate protection moderate numbers might again be induced to spend the summer months in these islands. 


\section{The Honey Buzzard}

The adult has the head greyish; upper parts brown; under parts white, barred and spotted on the breast. Length about 23 in.; wing 17 in.

\section{THE GREENLAND FALCON}

\section{Falco candicans, J. F. Gmelin}

This species breeds in the Far North, in Greenland, Jan Mayen, and Novaya Zemlya, migrating southwards in winter. A good many examples have from time to time been taken in Great Britain, chiefly, as would be expected, in Scotland and Ireland.

The adult is white, streaked on the upper parts with black, and sometimes slightly spotted below. Young birds are much more heavily marked. Length $21 \mathrm{in}$; wing $14.5 \mathrm{in}$. The female is slightly larger.

This Falcon may be distinguished in all ages by the prevailing ground colour being white.

\section{THE ICELAND FALCON}

\section{Falco islandus, J. F. Gmelin}

This species is confined to Iceland, though very closely allied forms may be found in South Greenland and Labrador. Its visits to these islands have not been nearly so numerous as those of the former species.

The general colour of the upper parts is brownish grey, 


\section{Birds of Britain}

becoming greyer with age, with pale buff markings. Under parts whitish, the flanks barred with dark brown. Length of male $21 \mathrm{in}$; wing $14.5 \mathrm{in}$; the female is rather larger.

\section{THE GYR FALCON}

Falco gyrfalco, Linnæus

Two examples of this Scandinavian and North Russian species have been obtained in England.

It is very closely allied to the Iceland Falcon, but the head is darker and the under parts are very thickly barred. Length 19.5 in.; wing 14 in.

\section{THE PEREGRINE}

\section{Falco peregrinus, Tunstall}

This noble species, the king of Falcons, is still, we are glad to say, by no means uncommon round our coasts, though as a breeding bird it has been banished from most of its inland eyries. To those who still keep up the ancient sport of hawking, an amusement, which to our minds comes nearer true sport than any of its latter-day substitutes, the Peregrine is the favourite bird, and a grand sight it is to see this beautiful species "ring up" above his prey and "stoop" at him with half-closed wings and unerring aim, when pursuer and pursued come down to ground, the former to 

PEREGRINE

Falco peregrinus

Adult (left). Young (right). 


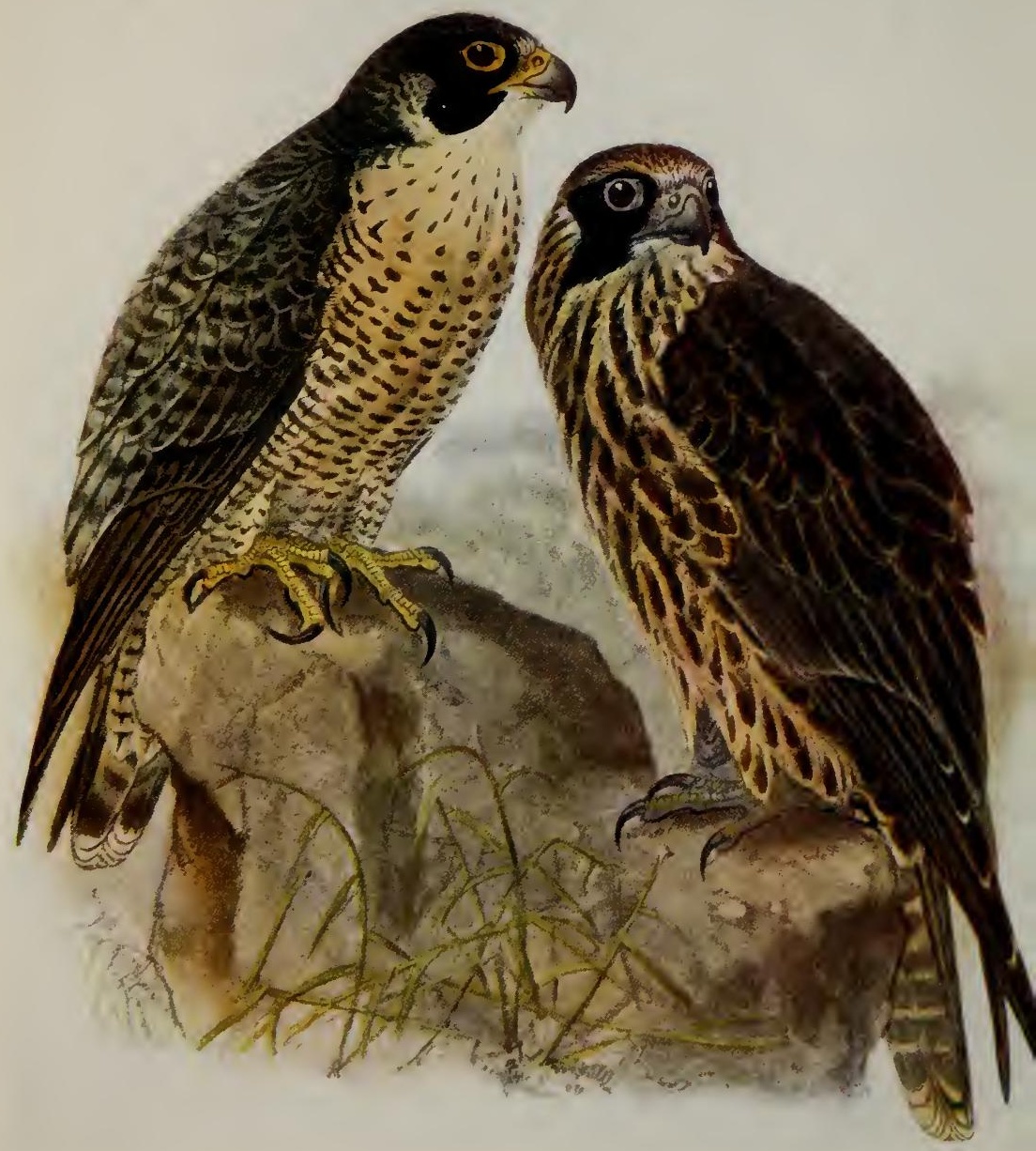





\section{The Peregrine}

earn the reward of his prowess and the latter to a happy despatch.

Agricultural conditions have had much to do with the decline of this sport, an amusement which lacks the onesidedness of a Pheasant or Partridge drive, and one in which the forces of nature are matched together.

The Peregrine, as its name implies, is a bird of passage, and visits on migration most parts of our islands. In the nesting season at the end of March or early in April it returns to its former eyrie, generally on some overhung ledge of a cliff on which there is a little earth, or more rarely in the old deserted nest of Rook or Crow. It adds no materials but lays its four beautiful yellowish eggs, which are thickly marked with deeper shades of orange and rufous, on the bare ground, or in the nest just as it was found. The young are covered at first with whitish down. Its food, which is always taken on the wing, consists of birds of all kinds, up to the size of a Crow, but Ducks, Sea-fowl, and Pigeons constitute, as a rule, its chief prey.

The young remain near their home for some time, till they are finally driven away by their parents, but the old birds, having once settled on a home, do not as a rule wander very far away from it. In its more northerly breeding haunts, however, both old and young migrate on the approach of winter.

The male, usually known in hawking parlance as the "tiercel," is much smaller than his mate, and has the upper parts slate grey; the under parts buffish white, barred with black. The crown and cheeks are also black. The female is browner and more thickly barred on the under parts. 


\section{Birds of Britain}

The young have buff margins to the feathers of the back and are striped instead of being barred below. Length of male 15 in.; wing 12.5 in. The female is larger.

\section{THE HOBBY}

\section{Falco subbuteo, Linnæus}

This species is very like a small Peregrine and comes to us yearly to rear its young. Although occurring throughout our islands, it is very local, being commonest in our southern and eastern counties. It very seldom nests north of Yorkshire, where it becomes rare. In the west of England and in Ireland it is almost unknown.

In flight and habits it closely resembles the Peregrine, its food consisting chiefly of small birds and insects.

An old Crow's or Magpie's nest is appropriated, and the eggs, usually three in number, closely resemble those of the Kestrel but are slightly smaller. Old and young leave us again in September.

The sexes are alike, and very dark slate grey on the back; chin white; under parts buffish, striped with black; thighs and vent red. Length about 13 in.; wing 10.5 in.

\section{THE MERLIN}

\section{Falco æsalon, Tunstall}

On moorlands and cliffs by the sea-shore, the Merlin is tolerably abundant from Wales northwards, but in the south 


\section{The Merlin}

of England it is rarely seen. The nest is a mere "scrape" among the heather, or when near the sea-coast a former Crow's nest on a cliff is frequently appropriated, and it has been known to lay its eggs in old nests on trees. The eggs are very like those of the Hobby and Kestrel, from which they can with difficulty be distinguished.

The Merlin preys almost entirely on small birds; its flight is very swift and powerful and it is very bold, attacking birds as large as itself. Larks and Thrushes are its favourite prey, and on the sea-shore it is very fond of Dunlins and other kinds of Sandpipers.

Resident with us throughout the year, it nevertheless wanders about a good deal during the winter and becomes generally distributed, but the adults for the most part remain near their breeding haunts.

The adult male is slate grey on the back, throat white, under parts buffish, striped with dark brown. Length 11 in.; wing $7 \cdot 8$ in.

The female is browner above and with pale under parts. She is also rather larger than the male. The young resemble the female but they are more rufous in tint.

\section{THE RED-FOOTED FALCON}

Falco vespertinus, Linnæus

This species is commonest in Eastern Europe, and is gradually extending its range northwards; it migrates to Africa in winter. Some thirty examples have at long 


\section{Birds of Britain}

intervals occurred in this country, chiefly in the east and south.

The adult male has the head, throat, breast, and upper parts very dark lead grey; thighs and vent chestnut. The female has the head and nape chestnut; upper parts slate grey, with darker bars; under parts pale chestnut. Length 11.5 in.; wing $9 \cdot 7$ in.

\section{KESTREL}

\section{Falco tinnunculus, Linnæus}

The Kestrel, or as it is sometimes called, "the Windhover," is one of the most graceful and harmless of our small Hawks. Year in, year out, he is with us, and his beautiful flight may be observed throughout these islands. He may be seen on any fine day high up in the air, remaining apparently motionless, but ever and anon keeping his position by a few rapid and quivering wing-beats, he will then turn slowly sideways and, revealing as he does so a red back and dark quills, he will describe a wide curve and again hang motionless in the wind. $\mathrm{He}$ is at last beginning to be recognised as one of the farmer's most useful friends, and as a perfectly harmless adjunct to the Pheasant covert, and thus he is yearly becoming more abundant. He feeds entirely on mice and small rodents, and only occasionally on small birds such as Larks.

Towards the end of April the Kestrel repairs with his mate to his former abode or to some convenient spot near 

KESTREL

Falco tinnunculus

Male (below). Female (above) 


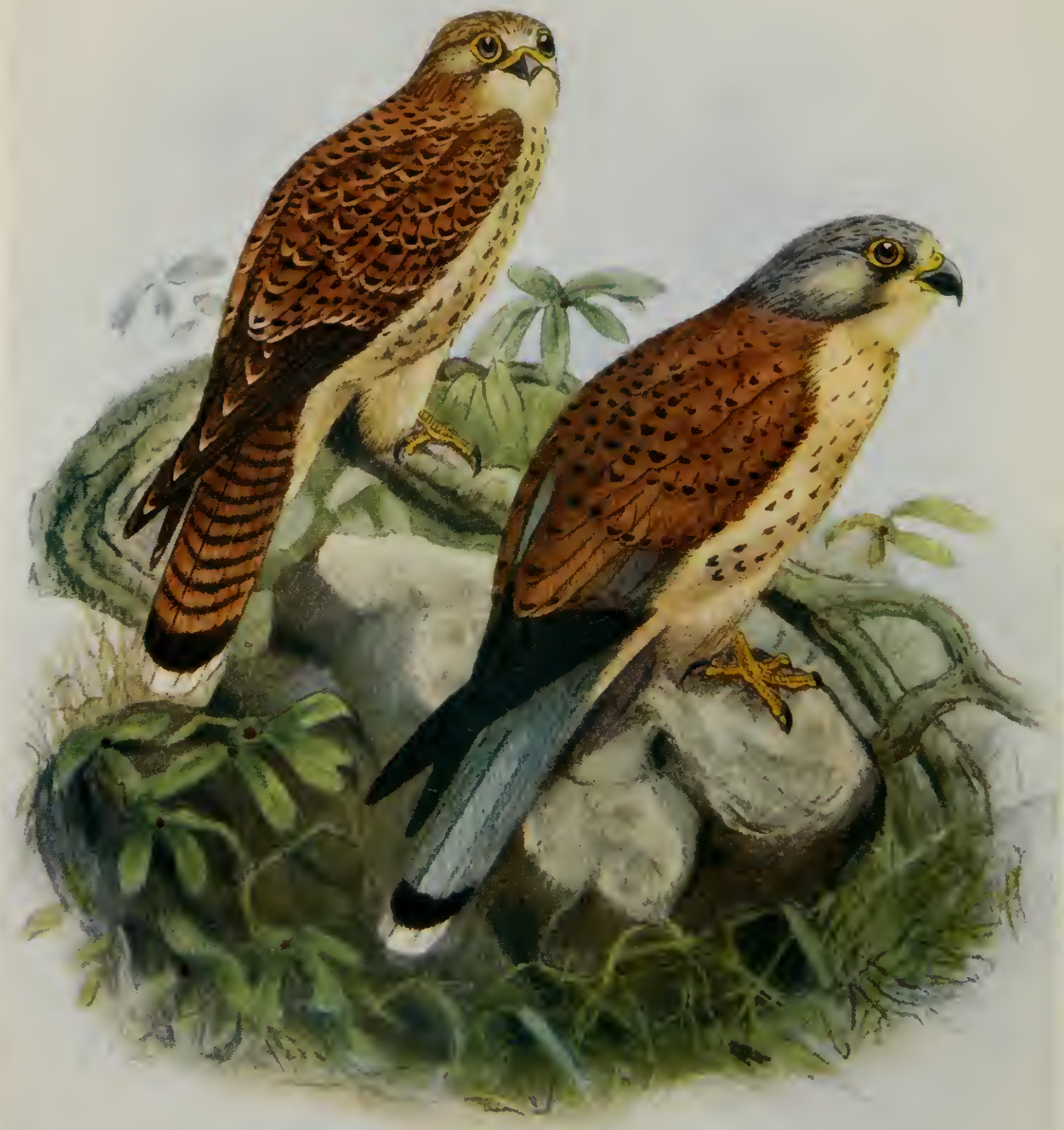





\section{Kestrel}

by. He does not build a nest for himself, but occupies the deserted home of a Crow or Magpie, a hole in a tree, if possible one which is open at the top, or the ledge of the cliff near the sea-shore. There, with little or no addition of material, the six eggs, of a beautiful rich red colour, are laid, but occasionally they have a paler ground colour and are blotched with deep red.

In about three weeks the young are hatched, and, as in the case of all birds of prey, are thickly covered with pale greyish down. At first their parents on bringing the food tear it up for them and allow the young to peck it from their beaks, but as they grow and their appetite increases (for their voracity at this age is enormous), the food is merely brought to the nest and the young tear it to pieces and eat it without further aid. Like several other birds, the Kestrel at such a time does not hunt in the immediate vicinity of his nest, and, except that he may occasionally be seen flying over, he is seldom "at home" to reveal the presence of his young. At the age of five or six weeks the young leave the nest; at first they do not fly much but remain perched near the nest and are still carefully watched and tended by the parents, while they gradually learn to catch and capture their own food.

At this time the family is always to be found near the nest, and that locality having been to a certain extent untouched, there is presumably abundant food for the young birds without their having to wander far afield. In this manner the summer passes, and as the days draw in and food becomes scarcer, the old birds become weary of their offspring and may frequently be seen fighting and driving 


\section{Birds of Britain}

them away. The young birds then take the hint, and leave the old folks at home, to wander forth all over the country and earn their living; many come down to the shore and emigrate, while others wander about till they find a suitable hunting ground in which to pass the winter.

With the advent of spring they have in their turn to seek a permanent home; perhaps they will meet with an older bird who has lost his mate during the winter and has a home ready, or perhaps they will inadvertently try to settle near an old eyrie and be driven away, but eventually a place will be found, and the inhabitants of a new district will be delighted, if they have eyes for Nature, by the charming ways and flight of their new visitors.

The adult male on the upper parts is of a deep chestnut, spotted or barred with black; under parts pale buff, striped with black. The head and nape are bluish grey, as is also the tail, which has a broad subterminal black band and is tipped with white. The female is more barred on the back and has the head brown, striped with darker. The tail is rufous, barred with black and slightly tinged with grey. The young resemble the female. Length 14 in.; wing $9 \cdot 5$ in.

\section{THE LESSER KESTREL}

\section{Falco cenchris, Naumann}

Very few examples of this small Hawk have been taken in this country. It is a summer visitor to Southern Europe, but towards the east it breeds in higher latitudes. 


\section{The Lesser Kestrel}

It may be distinguished from the Common Kestrel by its smaller size and white claws. Length $12 \cdot 26$ in.; wing $9 \cdot 2$ in.

\section{THE OSPREY}

\section{Pandion haliaëtus (Linnæus)}

This species may occasionally be seen on our shallow bays and estuaries or on inland lakes during the autumn migration, but its large size and conspicuous flight soon call forth a gunner and it is either shot or frightened away. It was never common in England, but in the eighteenth century it used to nest in a few localities. Nowadays only one or two eyries are known in the British Isles, and these are situated in remote parts of the Highlands of Scotland and zealously protected. Its food consists entirely of surface-swimming fish, on which it plunges from a considerable height.

The male has the head white, streaked with brown, rest of the upper parts brown; under parts white slightly spotted with brown on the breast. Legs greenish blue.

The female is rather larger and more spotted on the breast. The young have buff margins to the feathers of the back. Length 22 in.; wing 19 in.

\section{THE CORMORANT}

\section{Phalacrocorax carbo (Linnæus)}

With the Cormorant we come to quite another order of birds in which the feet, including the hind toe, are com- 


\section{Birds of Britain}

pletely webbed. Their food consists entirely of fish, which they obtain by diving and of which they consume an immense quantity.

The Cormorant is abundant round all our shores and nests in colonies on rocky cliffs.

Its breeding places are very numerous and may be said to occur pretty generally wherever suitable localities are to be found. The nest is an untidy accumulation of seaweed, and the eggs, usually five in number, are pale blue in colour, but are thickly covered with a white chalky encrustation.

The young are blind at first and covered with blackish down. They feed on half-digested food, which they procure by inserting their head and neck into the parents' crop. It is rather a sedentary bird, spending much of its time on rocks just above high-water mark; in diving it moves almost entirely by means of its feet, the wings being kept closely folded to its side. When searching for food it places its head under water, and on sighting a fish dives under with scarcely a ripple; on being captured the victim is brought to the surface and swallowed head first, and the search for another is recommenced. Having satisfied his hunger he mounts a rock and stands there erect, drying himself in the wind with outstretched wings, for in spite of their diving habits the feathers of these birds have very little power of resisting water, and after a prolonged immersion become quite saturated. It flies well and strongly with the head and neck outstretched in front and looks not unlike a Duck. In some places it nests inland near large lakes, and in such localities the nest is placed on trees. 



\section{SHAG}

\section{Phalacrocorax graculus}

Adult in breeding dress. Young on sea 


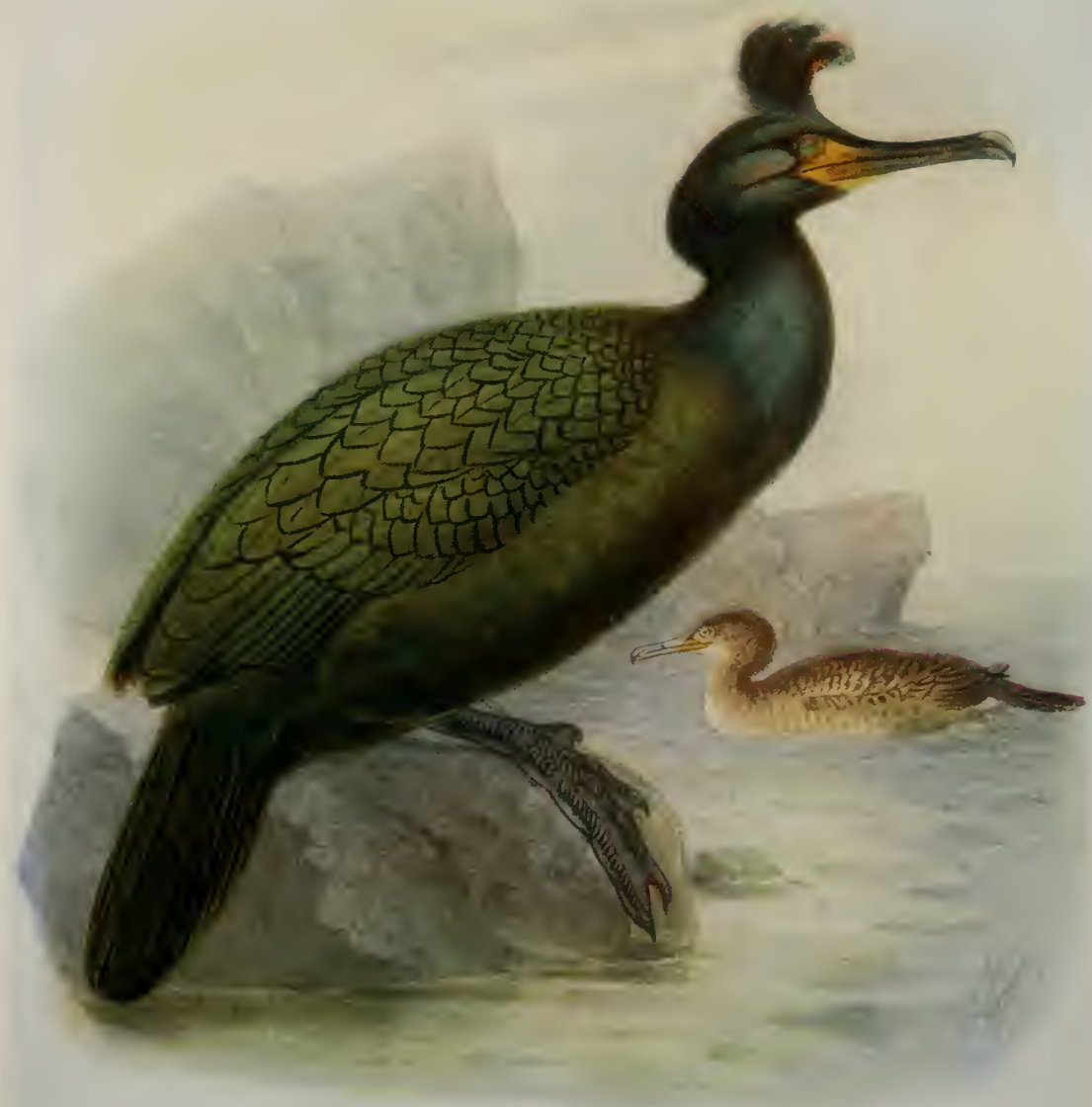





\section{The Cormorant}

The adult is of a deep glossy greenish black, which becomes more bronze in tint on the mantle. Many of the feathers on the head and neck are white, and there is a white patch on the thighs which is assumed during the winter and lost in May. The young are brownish and lack the gloss of the old birds; the under parts are whitish. They become adult in about three years. Length 36 in.; wing 14 in.

\section{THE SHAG}

\section{Phalacrocorax graculus, Linnæus}

The Shag is widely distributed round our coasts, especially those rocky portions abounding in caves, on the ledges of which it breeds. It is a smaller and more local species than the last, and is never found breeding inland and rarely in colonies. In all other ways it is a counterpart of its larger congener, with which it is often confounded by local fishermen.

During the breeding season it is rather noisy, the note being a harsh "kraik, kraik."

The adult is of a uniform glossy bronze green and wears for a short time in spring an upright and forwardly-directed crest. The young resemble those of the Cormorant except in size, but the tail has only twelve instead of fourteen tail feathers, and this forms an unmistakable character at all ages. The absence of the pale gular pouch will also enable this species to be recognised when on the wing. Length 27 in.; wing 10.75 in. 


\section{Birds of Britain}

\section{THE GANNET}

\section{Sula bassana (Linnæus)}

The Gannet is a local species, nesting in enormous numbers on certain rocks which have formed their home for centuries. These colonies are pretty well distributed round our coasts, especially in Scotland and Ireland, but in England, the Farn Islands on the east, and Grassholm in Wales, are their only strongholds, a former colony on Lundy Island being nearly, if not quite, exterminated. The Bass Rock, one of the largest and best known of these colonies, is, in summer, a sight never to be forgotten; the whole of the face of the cliff appearing entirely white, from the closely packed sitting birds, who at this season are very tame and allow themselves to be stroked while incubating.

The nest is a loose accumulation of seaweed and other materials picked up along the shore. A single egg only is laid, which, except in size, resembles that of the Cormorant. The young when first hatched are black and naked, but soon assume a thick covering of white down; they remain in the nest a long time, not leaving it until they are fully fledged.

A party of Gannets fishing is a beautiful sight; they are not divers like the Cormorant but feed on surface-swimming fish, and in winter often follow the shoals of herring and mackerel. Having marked his fish from high up in the air, the Gannet folds his wings and drops on it perpendicularly, striking the water with great force. When not at its breeding haunts it keeps more out at sea than its 


\section{The Gannet}

rock-loving congeners and is very seldom seen sitting on the shore.

The adult is pure creamy white, buff on the crown and nape, and with black primaries. In their first year the young are brown all over, each feather having a small triangular white spot at the tip. The adult plumage is not assumed until the fifth or sixth year, the plumage during youth being various intermediate stages. Length 34 in.; wing 19 in.

\section{THE COMMON HERON}

\section{Ardea cinerea, Linnæus}

Owing to its shy, retiring, and wary habits, this bird is still fairly common with us. It spends the late summer and winter in marshes by the sides of sluggish rivers and ditches, patiently waiting for some unwary fish to come within striking distance of its formidable bill. Frogs, snakes, rats, and mice are also equally relished, and it is by no means dainty or particular as to its food.

In former days it was strictly protected and used as quarry for hawking, in which chase the Hawk would often receive serious wounds from the deadly dagger-shaped beak.

The Heron nests in colonies on high trees, the nest being built of sticks, lined with small twigs, moss, and wool. Five eggs of a uniform greenish blue form the clutch, and the young, which are extremely helpless when first hatched, are carefully fed by their parents on predigested food. The flight of this species appears slow and lumbering. 


\section{Birds of Britain}

The legs are carried stretched out behind and the head and neck closely folded in to the body. When disturbed or alarmed they utter a harsh "frank, frank." Although usually nesting inland, they may often be found by the seashore in autumn and winter, especially during hard weather when their inland haunts are frozen over.

The adult is bluish grey on the upper parts; the head and neck are white with the exception of the crest, which is bluish black, as well as a row of dark longitudinal markings on either side of the neck. Under parts greyish white. Shoulders bluish black. The young resemble their parents but are browner and lack the long filamentous plumes on the back and base of the neck. The adult plumage is assumed by degrees, not reaching its full beauty till in the fourth or fifth year. Length 34 in.; wing 19 in.

\section{THE PURPLE HERON}

\section{Ardea purpurea, Linnæus}

The Purple Heron inhabits marshes in South and Central Europe, building a nest low down in the reeds, its nearest nesting place to us being in Holland. A good many examples, mostly immature, have occurred along our east coasts. On the back the adult is dark slate grey with rufous and buff dorsal plumes. Neck reddish, with dark elongated stripe down either side. Under parts rich maroon red. Immature birds are rusty red on the neck and upper parts, brownish on the under parts. Length 33 in.; wing $14 \cdot 25$ in. 


\section{The Great White Heron}

\section{THE GREAT WHITE HERON}

\section{Ardea alba, Linnæus}

Very few examples of this large species have occurred in Great Britain. It breeds on the Danube and thence eastwards in South Russia. The plumage is pure white, legs and feet black. This species has become much scarcer owing to persecution for its plumes, known as "ospreys." Length 33 in.; wing 17 in.

\section{THE LITTLE EGRET}

Ardea garzetta, Linnæus

This species breeds in Europe in the countries bordering the Mediterranean. It has only occurred in these islands on two or three occasions. Plumage pure white. Length 21 in. ; wing 11.25 in.

\section{THE BUFF-BACKED HERON}

\section{Ardea bubulcus, Audouin}

A scarce species in Southern Europe, but breeding in the marismas of Spain. It is often found perched on the backs of cattle. Only known in England from one example shot 


\section{Birds of Britain}

in 1805 . Plumage white, except the crown, nape, and back, which are saffron yellow. Length 20 in.; wing $9 \cdot 5$ in.

\section{THE SQUACCO HERON}

\section{Ardea ralloides, Scopoli}

The Squacco Heron breeds in suitable localities throughout Central and Southern Europe, and has visited this country on a good many occasions, generally during the spring immigration. Head, neck, and back pale buff, the crown and nape streaked with dark lines. Sides and front of the neck buff; under parts white. Length 20 in. ; wing 9 in.

\section{THE NIGHT HERON}

\section{Nycticorax griseus (Linnæus)}

This species has frequently occurred on our south and east coasts at irregular intervals, and on one occasion eight adult birds were destroyed during the breeding season, when they might possibly have nested. It breeds chiefly in Southern and South-eastern Europe, but a few pairs still nest in Holland and Northern Germany.

The crown, nape, and back of the adult are greenish black; the neck, tail, and wing coverts drab; the under parts greyish white. Length $23 \mathrm{in}$; wing $12 \mathrm{in.}$ 


\section{The Little Bittern}

\section{THE LITTLE BITTERN}

\section{Ardetta minuta (Linnæus)}

This species is abundant in summer throughout Central and Southern Europe, migrating to Africa for the winter months. To Northern Europe it is only a scarce straggler, but in the United Kingdom it has been obtained fairly frequently, especially in our eastern and southern counties, and there is little doubt that it has on more than one occasion stayed to breed. It inhabits thick reed-beds, and when disturbed either creeps away with great speed through the vegetation or remains motionless with head erect, in which position it closely resembles the reeds.

The male has the crown, nape, back, quills, and tail greenish black, the rest of the plumage buff, paler on the wing coverts. The female has the crown, nape, and back brown, and the under parts buff, streaked with brown. The young resemble the female. Length 13 in.; wing 6 in.

\section{THE COMMON BITTERN}

\section{Botaurus stellaris (Linnæus)}

Owing to drainage and cultivation, the Bittern, which used formerly to breed in various swamps and reed-beds, especially in our eastern counties, is now only known as a migrant. It still occurs yearly on our shores, and if 


\section{Birds of Britain}

unmolested it is probable that it would once more nest with us.

The nest is a heap of reeds placed on the marsh in the thickest part of a reed-bed. The eggs are usually four in number and of a uniform brownish olive colour. In the breeding season it utters a loud "booming" noise, but at other times it is a very silent bird.

The adult is buff, irregularly barred and streaked all over with black, except on the head, which is pure black. Sexes and young are alike in plumage. Length 28 in.; wing $13 \mathrm{in.}$

\section{THE AMERICAN BITTERN}

\section{Botaurus lentiginosus (Montagu)}

This bird was, curiously enough, first described from a specimen killed in Dorset. It is a purely American species, but a good many examples have been taken in all parts of the United Kingdom. It may be distinguished from the preceding species by its smaller size, darker coloration, and uniformly brown primaries. Length 24 in.; wing $11 \mathrm{in.}$

\section{THE WHITE STORK}

\section{Ciconia alba, Bechstein}

It is curious that a bird so common and well protected on the Continent should not be of more general occurrence 228 



\section{BITTERN}

Botaurus stellaris 


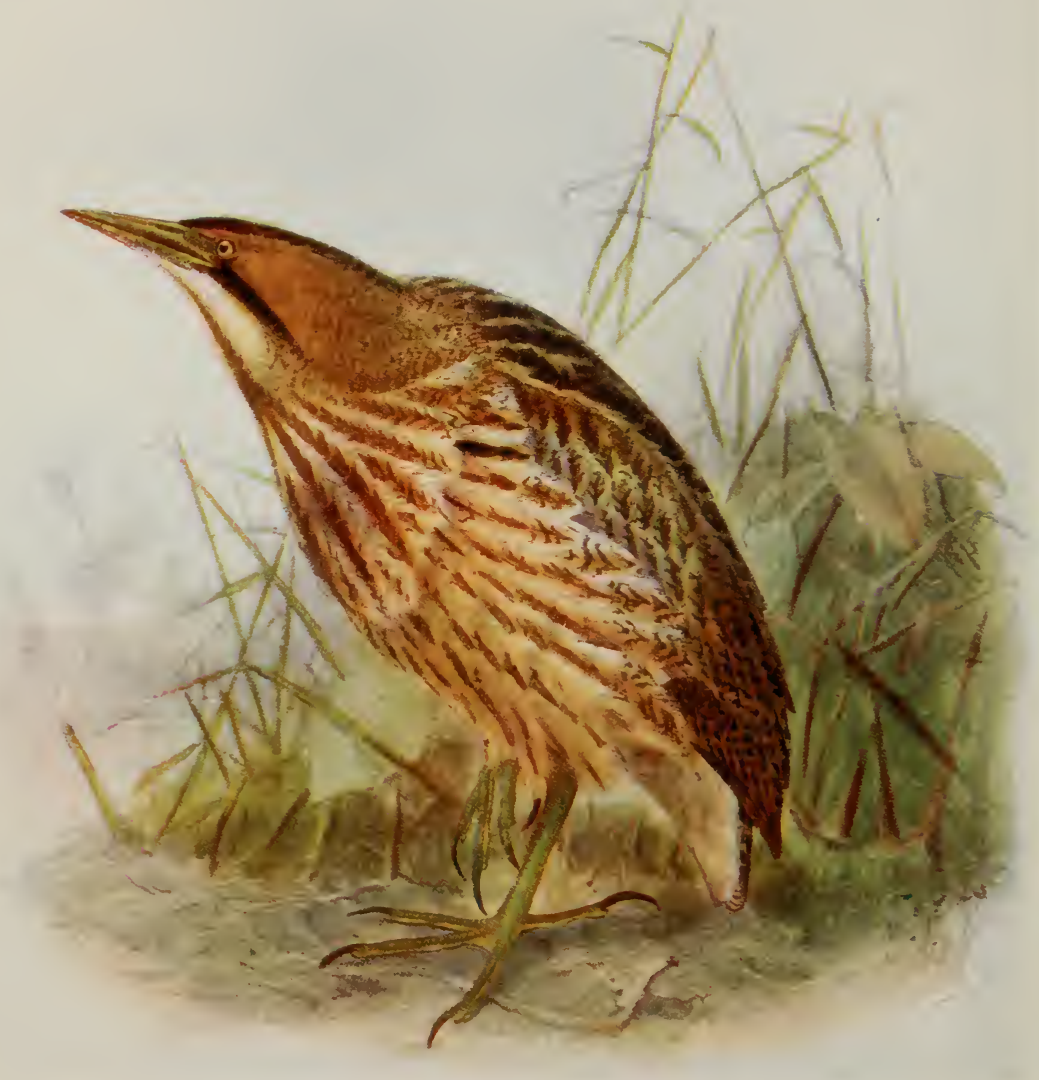





\section{The White Stork}

in these islands. It can only be considered a rare straggler, most of the examples having been seen in spring.

The whole plumage is white, except the quills, which are black. Legs and bill crimson. Length $40 \mathrm{in.}$; wing $23 \mathrm{in}$.

\section{THE BLACK STORK}

\section{Ciconia nigra (Linnæus)}

Some fourteen examples in all of this fine bird have been procured in England. It breeds in Sweden, Denmark and East Germany and thence eastwards in Central and Southern Russia. Like the White Stork, it is a migrant, wintering in Africa.

The whole of the plumage is black, with metallic reflections, except the lower breast and vent, which are white. Length 38 in.; wing 21 in.

\section{THE GLOSSY IBIS}

\section{Plegadis falcinellus (Linnæus)}

In the southern and eastern parts of England this species used to be well known as an autumn migrant, but of late years it has become decidedly scarcer. It breeds commonly in the marismas of Spain and the marshes of the Danube.

The head, neck, and under parts are a deep coppery brown; back, wings, and tail glossy brownish black. The bill is long and shaped like that of a Curlew. The sexes 


\section{Birds of Britain}

and young are alike in plumage. Length 22 in.; wing 10.75 in.

\section{THE SPOONBILL}

\section{Platalea leucorodia, Linnæus}

This species used formerly to breed in several localities in England, but these have long been deserted. It, however, still occurs on migration, and a few annually visit the Norfolk Broads in spring, where, as they are now strictly protected, it is to be hoped that they may once again be induced to nest. It still nests in Holland, but in other districts where it used to occur it seems to have died out as a breeding species, and is now restricted to more southern localities, such as the south of Spain, the Danube, and the Black Sea.

The whole of the plumage is white; gular pouch orange; bill black, with yellow tip; legs black. The sexes are alike in plumage. The young may be distinguished by the black ends to the quill feathers and the flesh-coloured bill. The adult plumage is not fully assumed till in the second or third year. Length 36 in.; bill 8.5 in.; wing 14.5 in.

\section{THE FLAMINGO}

\section{Phœnicopterus roseus, Pallas}

This curious and well-known bird is only a very rare straggler to our shores. It breeds in the Camargue district 230 


\section{The Flamingo}

at the mouth of the Rhone as well as in Spain, but its main breeding grounds are in Africa. It nests in colonies, the nests being conical structures, formed of mud, built near the edge of the water. It is now definitely ascertained that it sits with its long legs doubled up, and not straddle-legged as was stated by early travellers. The food consists of minute crustacea and other insects.

The adult is of a pale rose pink all over, darker on the wing coverts. The quills are black. Legs pink; bill rosy, with black tip. The young are of a pale mottled brown. Length about $5 \mathrm{ft}$.; wing 15 in.

\section{THE GREY LAG GOOSE}

\section{Anser cinereus, Meyer}

Although about a century ago this bird used to nest in the fens of Cambridge and Lincolnshire, it has long since ceased to do so, and the only places where it may still be found breeding in these islands are in the north of Scotland and in the Outer Hebrides. In winter it occurs on our coasts in company with other species of Geese, but it is by no means common, and the majority pass on to the south, reappearing on their way north in spring. The food consists chiefly of grass and other green food, which it seeks on salt marshes near the sea by day, retiring to the shore to rest at night. It is the only Goose that breeds in our islands. The nest is begun in the middle of April and consists merely of a "scrape" amongst the grass or heather which is lined, 


\section{Birds of Britain}

as incubation proceeds, with down plucked from the body of the female. The eggs are usually six in number and dull yellowish white in colour.

As soon as the female begins to sit the males gather together in small flocks and take no further interest in their mates. Geese are strong fliers, and, being very wary birds, extremely difficult to approach. In flight they usually assume a wedge-shaped formation known as a "skein." The note is a harsh "gaggle, gaggle," like that of our domestic Goose, which is supposed to have originated from this species.

There is some doubt as to the origin of the name Grey Lag, but it is now generally conceded to have been applied to this species because it lagged behind after the other Geese had gone to their breeding quarters in the north.

The adult is greyish brown on the upper parts and breast, the rest of the under parts being whitish grey with a few black feathers. The young are rather darker and lack the black feathers underneath. Length 34 in.; wing 17 in.

\section{THE WHITE-FRONTED GOOSE}

\section{Anser albifrons (Scopoli)}

This Goose, whose chief breeding grounds are in Siberia, though it also nests across the whole of Northern Europe, visits us in fair numbers every winter, but it is more abundant in the south and south-west than on the east coast, and is everywhere very local in its distribution.

It very closely resembles the Grey Lag Goose, but there 


\section{The White-fronted Goose}

is more white on the forehead; the bill is orange yellow with white nail, and the legs orange. Length $27 \mathrm{in.}$; wing 16 in.

\section{THE BEAN GOOSE}

\section{Anser segetum (J. F. Gmelin)}

This species nests throughout Northern Europe and Asia. It is common on our coasts in winter, and is in fact the most abundant of our wild Geese. In Scotland, however, it is not so numerous as the preceding species.

This bird feeds inland on grain and vegetation.

The bill is black, with an orange band across the centre and a black nail; the amount of orange on the bill varies, however, in individuals, and several forms have been differentiated, though the matter requires further confirmation before being finally accepted. The amount of orange in the bill may also vary, in some cases, during the life of a single individual. Legs orange yellow. There is no bluish grey on the shoulder of the wing, as in the Grey Lag and Pink-footed. Length 34 in.; wing 19 in.

\section{THE PINK-FOOTED GOOSE}

\section{Anser brachyrhynchus, Baillon}

On the east of England and Scotland this species is very plentiful during the winter, but in the south of England and on our west coasts it is comparatively rare, and its occurrence in Ireland is not yet authenticated. It 


\section{Birds of Britain}

breeds in Northern Europe and is apparently the only "Grey Goose" breeding on Spitzbergen.

The bill is black, with pink across the centre and a black nail. Legs pink. This pink colour has sometimes a yellowish tinge and so cannot be accepted as a definite character on which to diagnose this species. The wing, however, in the Pink-footed Goose is blue grey, approaching that of the Grey Lag, and this, together with its smaller size, will distinguish it from the preceding species. Length 28 in.; wing 17.5 in.

\section{THE SNOW GOOSE}

\section{Chen hyperboreus (Pallas)}

This is a North American species, breeding in Arctic Regions and wandering south in winter. It has occurred several times in Ireland, and small flocks were seen in Cumberland, Northumberland, and Yorkshire during the severe winter of 1890-91.

The adult is pure white, with black quills. The young is brownish grey on the back, lighter on the under parts. Length about 30 in.; wing 17 in.

\section{THE RED-BREASTED GOOSE}

\section{Bernicla ruficollis (Pallas)}

Only one or two examples of this rare Goose have been obtained in this country. It breeds in Eastern Siberia, 


\section{The Red-breasted Goose}

whence it migrates southwards past the Ural and Caspian Seas.

The general colour above is black; the ear patches, throat, and breast chestnut; lores and belly white; chin black. Length 21 in.; wing 14.5 in.

\section{THE BERNACLE GOOSE}

\section{Bernicla leucopsis (Bechstein)}

Nesting abundantly in Greenland and in some numbers on Spitzbergen, the Bernacle Goose is by no means uncommon in winter along the west coast of the United Kingdom as far south as Lancaster, as well as on the north coast of Ireland. Elsewhere in these islands it is decidedly rare. It feeds on grass pastures near the sea, almost invariably by night.

This species is commonly kept in captivity, where it breeds freely.

The crown of the head, neck, and upper breast are black; mantle grey, barred with black and white; forehead, cheeks, and chin white. Under parts greyish. Tail coverts pure white. Length 27 in.; wing 16 in.

\section{THE BRENT GOOSE}

\section{Bernicla brenta (Pallas)}

This species is one of the most abundant of our Geese, and is found in enormous flocks round our 235 


\section{Birds of Britain}

coasts throughout the whole winter. It breeds along the west coast of Greenland and also on the islands and northern coasts of Russia and Siberia. It feeds chiefly by day, and is fond of wading about in mud-flats or in shallow water feeding on aquatic vegetation.

The whole plumage is chiefly black, except the tail coverts, which are white, and a white patch on each side of the neck. Length $22 \mathrm{in.}$; wing 13 in.

\section{THE WHOOPER SWAN}

\section{Cygnus musicus, Bechstein}

Formerly breeding in small numbers in the Orkneys, this species now only visits us during the winter, its numbers depending largely on the severity of the climate in Northern Europe. It frequents bays, estuaries, and inland lakes, feeding on weeds and aquatic vegetation. The note is a loud "whoop, whoop, whoop," from which its trivial name has been derived, and is often uttered as they fly along the shore in a long straggling line. The sexes are alike in plumage, as are all palæarctic Swans, and this species may be distinguished by the colour of the bill, which is black at the tip and yellow at the base, the yellow extending forward beyond the openings of the black nostrils. The base of the bill is flat and quadrangular and not knobbed as in the Mute Swan. Length 60 in.; wing $25 \cdot 5$ in. 


\section{Bewick's Swan}

\section{BEWICK'S SWAN}

\section{Cygnus bewicki, Yarrell}

This species, which is smaller than the Whooper, visits us regularly every winter, and is in some places the commoner of the wild Swans. In Scotland it is abundant in some seasons as it is also in Ireland, but on the coasts of England and Wales it is always rather scarce. It breeds in the Far North to the east of the White Sea.

It may be distinguished from the Whooper by its smaller size and the extent of the yellow on the beak, which does not quite reach the nostrils. Length about 46 in. ; wing about 21 in.

\section{THE MUTE SWAN}

\section{Cygnus olor (J. F. Gmelin)}

In this country the Mute Swan is only met with in a state of semi-domestication, having been introduced at some early period of history. It is now, however, widely distributed throughout our islands. Inhabiting lakes, rivers, and ornamental waters, it feeds on aquatic weeds and grain, and is extremely useful in preventing an undue growth of weeds in ornamental ponds and lakes. The nest is a huge structure of straw and rushes, built upon the edge of the water, or in the centre of a reed-bed. The eggs, which vary in number 


\section{Birds of Britain}

from five to nine or ten, are of a uniform pale greeu, and are hatched after some five weeks' incubation.

The young, which are covered at first with greyish down, are carefully tended by both parents, and when tired nestle on their parents' back. In olden times the right to keep Swans on the Thames was granted by the King to many of the City Companies, and in the autumn of each year (a custom which is still continued) the young Swans are caught up and marked on the bill with the private mark of the Company to whom they belong. This is known as "Swan upping." The male is known as the "Cob" and the female as the "Pen," and the rules and regulations clearly state how the brood shall be awarded in the event of the Cob and Pen belonging to different Companies, while the landowner on whose ground they nest also comes in for a share.

At the nest the male Swan is very savage, attacking any intruder with his bill and with savage beats of his powerful wings; his mate, however, is very quiet and will allow herself to be pushed off the nest with no stronger protestation than a subdued " hiss."

This Swan is not mute as its name implies, but has a loud trumpet-like note, to which, however, it seldom gives utterance.

In a purely wild state, this species may be found breeding in Denmark and the south of Sweden, and it is a common breeding species in South-eastern Europe. From its northern breeding haunts it migrates in winter, many probably coming over to our shores.

The plumage is pure white; the bill reddish orange with 238 


\section{The Mute Swan}

a black knob at its base. This knob is much larger than in the male. The young are greyish drab. The so-called "Polish Swan" is a variety of this species, in which the young are white. Length about 56 in.; wing 27 in.

\section{THE COMMON SHELD-DUCK}

\section{Tadorna cornata (S. G. Gmelin)}

Although somewhat local in its breeding haunts, this species is fairly abundant round all our coasts in winter. It is a Sea-Duck, being seldom found far inland, and its food consists of small mollusca and marine insects, which it seeks on our flat estuaries and along the shore.

A rabbit-burrow in sand-dunes near the sea is chosen for a nesting-site, and lined with a little grass, to which is subsequently added an abundance of grey down from the body of the female. Occasionally it makes its own burrow, or other sites such as crevices between boulders or under furze bushes are selected. The eggs, generally ten in number, are creamy white. As soon as they are hatched the mother leads her brood to the shore, where they feed, making for the sea on the first sign of danger.

During the pairing season this bird is very noisy, the male uttering a short whistle, while both sexes run round each other with out-stretched neck, making a curious guttural chuckle.

In winter large flocks of these birds visit us from the Continent. These flocks may be seen resting out at sea by 


\section{Birds of Britain}

day and come in to feed on the soft ooze by night; they are of course more partial to flat and sandy parts of the coast, but may nevertheless often be found in small sandy bays on an otherwise rocky shore.

The head and neck are glossy bluish black; the scapulars and primaries black. There is a broad band of bright chestnut across the back and breast, and a black stripe along the centre of the under parts. Speculum green. The rest of the plumage is pure white. Legs flesh pink; bill crimson. The sexes are alike, but the female is smaller and duller. The male has a crimson knob at the base of his bill which swells up considerably during the breeding season.

The young bird lacks the chestnut band, the head and neck are dull brownish black, the scapulars greyish brown, and in its first autumn it assumes a plumage similar to the adult female, but duller. Length 25 in.; wing 13 in. Both sexes assume in July a much duller plumage, somewhat resembling that of the young in their first winter.

\section{THE RUDDY SHELD-DUCK}

Tadorna casarca (Linnæus)

The Ruddy Sheld-Duck is a South-eastern European species, breeding on the shores of the Levant and throughout Northern Africa, but it is rare on the north shores of the Mediterranean west of the Adriatic. It has several times been noted as a straggler to England, and in 1892 many flocks appeared in different parts of the country. 



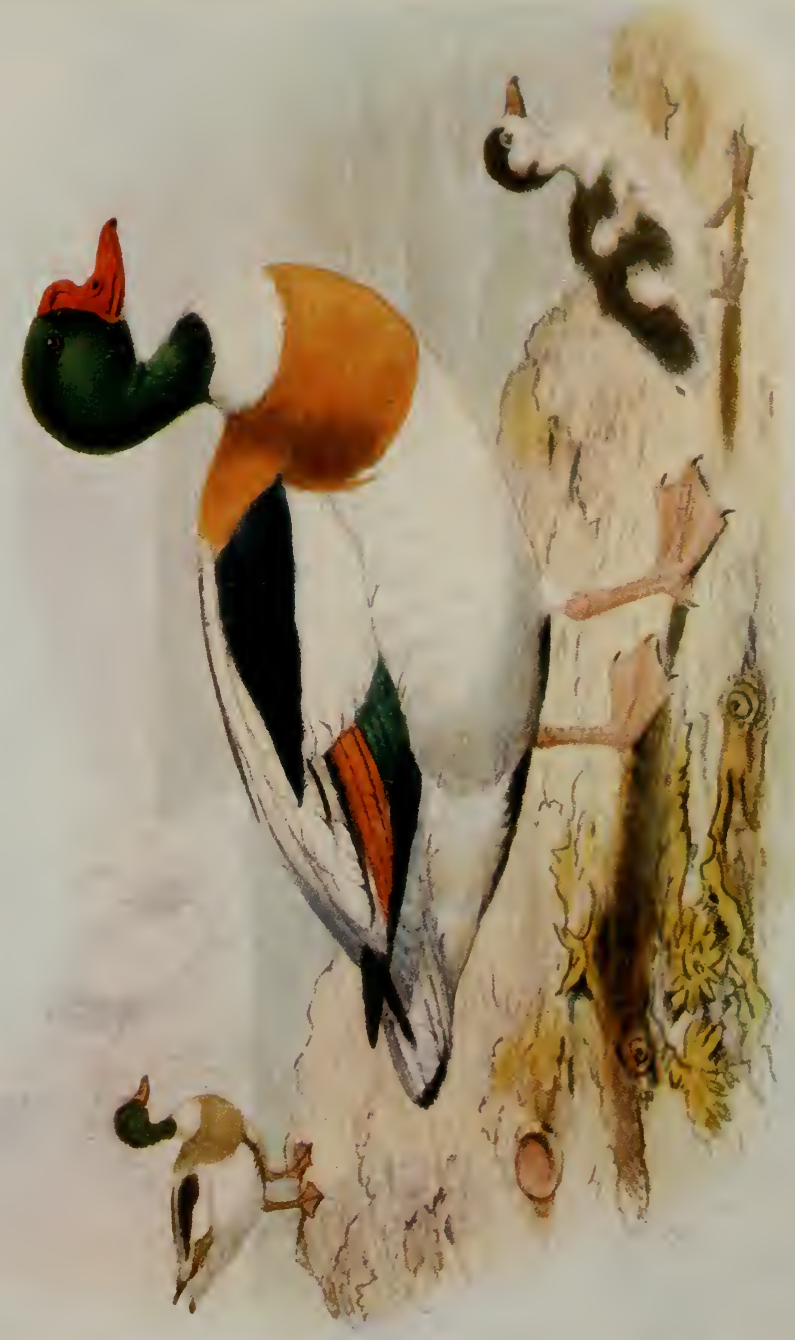





\section{The Ruddy Sheld-Duck}

The general colour is a deep orange brown, the head being rather lighter. The male has a narrow black collar during the nesting season. The female is much paler on the head, the forehead, lores, and a ring round the eye being nearly white. Length 25 in.; wing 14.5 in.

\section{THE MALLARD OR WILD DUCK}

\section{Anas boschas, Linnæus}

This is at once our commonest and most beautiful Duck. Owing to drainage of fen-lands and higher cultivation it is, perhaps, not so abundant as formerly, yet there are few marshes or low-lying lands of any extent in our islands, which do not afford a home to a few pairs of this species.

It feeds chiefly by night on worms, aquatic insects, water weeds, and grain, and prefers ditches overgrown with weeds or shallow ponds to open stretches of deep water. Early in March it chooses a nesting site, usually on the ground and at no great distance from water, but exceptionally it has been known to nest in trees, faggots, stacks, and other elevated places. No nest is formed, but a cup-shaped hollow is scraped out, which is warmly lined with down after incubation commences. The eggs, usually ten to twelve in number, are pale greenish yellow, and are always carefully covered up by the Duck on leaving the nest. They hatch after twenty-seven days' incubation, and the young are then taken to the nearest water, on or near which they remain for about two months till they can fly. If, 


\section{Birds of Britain}

however, they are much disturbed they will be led away by their mother to a neighbouring piece of water, often at some considerable distance.

In a wild state the Mallard, as the male of this species is called, is strictly monogamous, and during the whole of incubation he will remain in the vicinity of the nest, warning his mate of the approach of danger, and accompanying her when she comes off to feed. Once the young are hatched he retires to some secluded and sheltered piece of water, where he assumes a dull plumage, somewhat resembling that of the female. During this period he becomes very skulking, rarely showing himself on the open water. When his dull or "eclipse" plumage has been assumed, he casts all his flight feathers at once, and for a short time becomes incapable of flight. These grow again in about a fortnight, and then in September he begins to assume his brilliant colours once more, and comes from his secluded retreat to join his comrades. In the winter they gather in large flocks, which resort to open sheets of water or the sea, flighting every evening to the marshes and shore to feed, and retiring again at daybreak to rest on the water.

It is these daily movements of Duck that are known to sportsmen as "flights," and they afford excellent shooting to the gunner concealed on their route. Vast numbers of this and other species of Duck used formerly to be taken in decoys, but partly owing to decrease in the numbers of the fowl, or still more to the increase of shooters, who frighten them away, few if any decoys are now worked at a profit in this country. A decoy is a pond in a suitable locality near the sea surrounded by trees and having two or four 




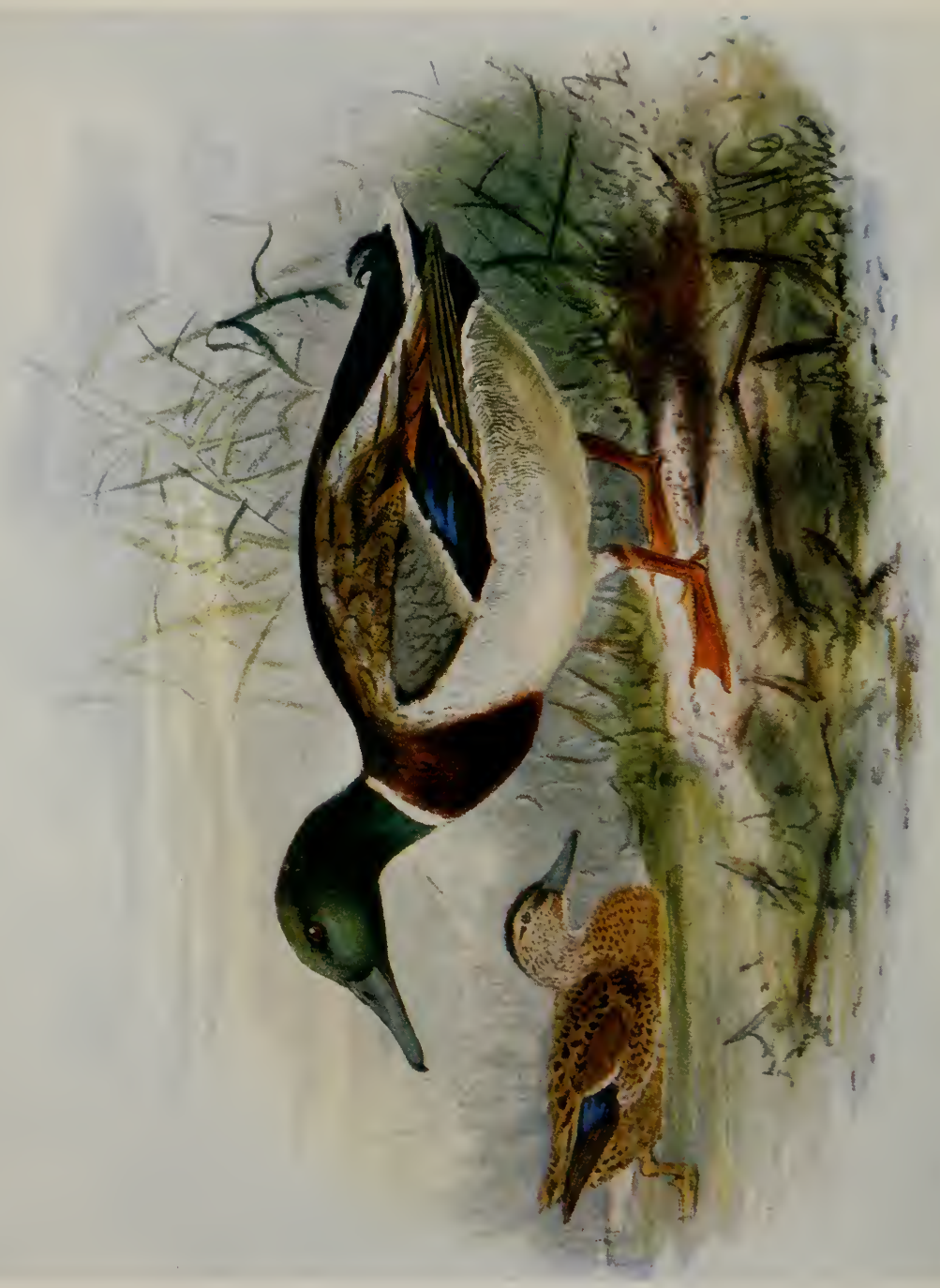





\section{The Mallard or Wild Duck}

curved arms known as "pipes" running up at the different corners. These pipes are covered with netting, and end in a small bag net. The Duck are enticed up by tame birds and by means of a red dog that they follow out of curiosity. When some way up the pipe they see behind them the decoyman, who has hitherto been concealed by an ingenious arrangement of reed-screens, and rather than turn back and face him, they rise and fly up the pipe into the net. The whole operation must be carried out in silence so as not to scare the other birds on the pond, who remain in complete ignorance of their comrades' fate. Absolute quiet and plenty of food are the essentials for the successful working of a decoy. They are still used in Holland, where they form a considerable source of profit to their owners; their number is limited, and a licence has to be paid for each decoy.

After the brood can fly the Duck loses her primaries and becomes incapable of flight for a short time, but as soon as her quills are grown the whole family move off to join the flocks, which are now rapidly forming. Large numbers visit us yearly from abroad, and a spell of severe weather in midwinter still further increases their numbers.

The male has a glossy green head and neck, the latter being encircled by a narrow white ring; rump and tail coverts glossy greenish black, the four central coverts upturned; chest and breast deep chestnut; rest of under parts pale grey, vermiculated with black; bill greenish yellow; legs orange. The Duck is dark brown, the feathers having paler edgings. The young resemble the female, but the males have assumed their full dress by October. The 


\section{Birds of Britain}

male in eclipse has a plumage which approximates to that of the female. Length $23 \mathrm{in.}$; wing 11 in.

\section{THE GADWALL}

\section{Anas strepera, Linnæus}

The Gadwall is a scarce visitor to our shores, occurring irregularly along the east coasts of Scotland and England, but it is very rarely seen in the west or in Ireland. In a few places in Norfolk, where it was originally introduced, it breeds, and has of late years considerably increased both there and in the surrounding counties. In habits it resembles the Mallard. The eggs are usually ten in number and of a delicate creamy pink. It may be easily recognised on the wing by its white speculum.

On the Continent it nests in Central and Eastern Europe, its breeding range extending to the far north of Russia. It winters in the Mediterranean basin.

The adult male is greyish brown, with darker mottlings on the head and neck; back dark brown, with greyish markings; median wing coverts chestnut; greater coverts almost black. Under parts white, grey on the flanks and vent. Under tail coverts black. The female is marked with dark brown and buff much like a Wild Duck, but is recognisable by the white speculum. The young somewhat resemble the female. The white speculum forms a distinctive mark of this species at all ages. Length $20 \mathrm{in.}$; wing 10.5 in. 


\section{The Shoveller}

\section{THE SHOVELLER}

\section{Spatula clypeata (Linnæus)}

This bird is by no means rare with us in winter, when large numbers come over from abroad. It is essentially an inland species, preferring small and sheltered pieces of water rather than wide open stretches. Its most characteristic feature is the large flattened bill with which it feeds on the surface-swimming animalculæ and other insects, the broad lamellæ of the mandibles forming an efficient strainer. When feeding three or four will often follow each other in a circle, each feeding in the other's wake. Of late years it has become more numerous as a breeding bird, and it now nests commonly in the Broads and other districts of Norfolk and the eastern counties. In Kent and the Midlands, Yorkshire and the North, it nests sparingly, as well as in some of the southern and eastern counties of Scotland. In Ireland it is a local but by no means scarce species. Except in the breeding season it is a very silent bird; when courting it moves its head up and down, uttering a low "took, took," which is answered by the female. The nest is generally placed at some distance from the water in the middle of a dry grass-field, where there is hardly any cover beyond a small patch of grass more luxuriant than the rest.

The eggs, which number from eight to ten, are pale greenish buff in colour. The female sits very closely, and the male remains in attendance at no great distance and 


\section{Birds of Britain}

accompanies her when she comes off to feed. The incubation period of this species is rather shorter than with most Ducks, and lasts between twenty-one and twenty-three days. The young are solely looked after by the Duck, and when first hatched their bills show no trace of the broadening and flattening, characteristic of the adult.

During the summer the Drake assumes an "eclipse" plumage, which somewhat resembles that of the Duck. In October he begins, unlike most other species, to assume an "intermediate" plumage, in which the head is very dark but not metallic, and the white of the breast is obscured by dark transverse bars. The full plumage is not usually complete till the end of February or early in March.

In this country our breeding birds are practically resident, only shifting from their nesting-quarters when frozen out. The majority of birds met with, however, in winter are immigrants from the Continent, who leave us again in March.

The adult Drake in full plumage is a beautiful bird. The head and upper neck are metallic green; lower neck, breast, and scapulars white; back brown; shoulders pale blue; greater wing coverts white. The under parts are deep chestnut; speculum green; bill black; legs orange.

The Duck is dark brown, with light rufous buff edgings to the feathers. Shoulders bluish. The young at first resemble the Duck, and in November begin to assume the "intermediate" plumage described above, except that the breast feathers are spotted and not barred. It does not always assume its full plumage in the first year.

$$
246
$$



SHOVELLER

Spatula clypeata 


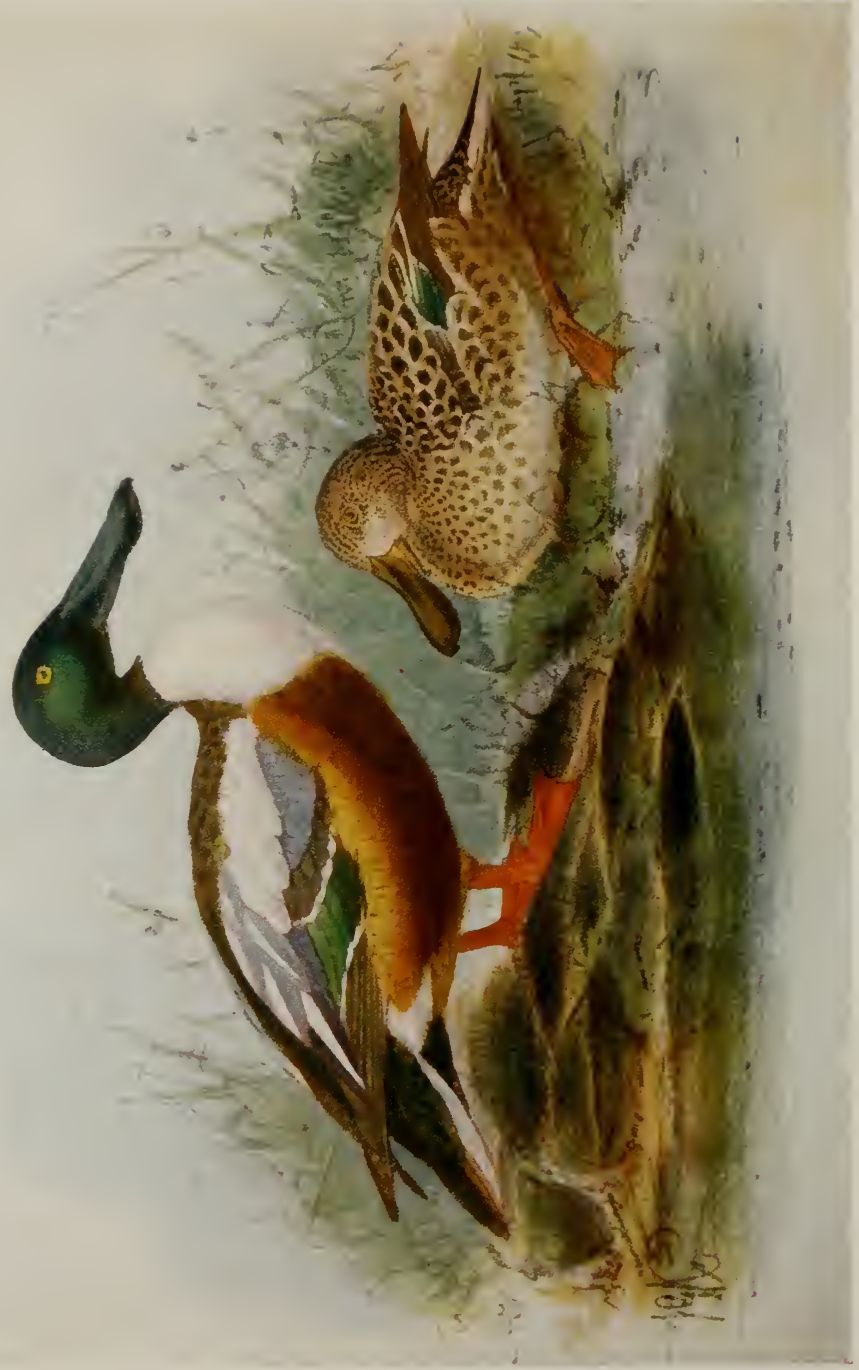





\section{The Pintail}

\section{THE PINTAIL}

\section{Dafila acuta (Linnæus)}

This species visits us in large numbers during the winter, arriving in September and not leaving our shores till April. During this period it is essentially a Sea-Duck, haunting shallow shores and estuaries, where it feeds on aquatic vegetation, crustacea, and other animal life brought in by each tide. It is commoner on the east coast than elsewhere owing to the large tracts of shore suited to its habits, but it may be found in smaller numbers on the west and in Ireland, wherever suitable localities exist.

It is only of late years that it has been known to nest in this country, a small colony having established themselves on one of the Scotch lochs. Elsewhere it breeds abundantly throughout Northern Europe, migrating southwards in winter. The nest is placed in a dry situation, at some little distance from the water. The eggs are rather elongated in shape and pale buffish green in colour.

The adult male has a brown head, greenish black on the nape. A white stripe runs down the neck on either side, merging into the white of the under parts. Back and flanks dark brown, mottled with grey. Wing coverts buff; speculum bronze green; tail black, the two central feathers much elongated; under tail coverts black; bill and legs slate grey. The female is of varying shades of buff and brown. The elongated neck and general shape of this species is sufficient to distinguish it from others of its family. 


\section{Birds of Britain}

The young resemble the female, and moult directly into their full plumage in their first autumn. The eclipse plumage of the Drake, which is dark brown above and smoky grey below, is lost about October. Length 26 in.; wing $11 \mathrm{in.}$

\section{THE TEAL}

\section{Nettion crecca (Linnæus)}

This is the smallest of our native species of Duck, and is fairly common throughout our islands at all times of the year, but its numbers are largely augmented in winter by the arrival of vast flocks from abroad. It may be found in winter near the mouths of rivers and shallow estuaries as well as inland; its food consists of grain, insects, worms, slugs, and molluses.

It breeds throughout our islands, but more abundantly in the north. The nest is generally placed at some distance from water on a dry moorland or rough grass-field, and this species makes a rough nest of leaves and grass, lined with down. The eggs, eight to ten in number, are creamy white.

The male has the crown, nape, cheeks, and throat chestnut; an elongated patch of purplish green behind the eye, the rest of the upper parts vermiculated with black and white except the rump and tail coverts, which are black. Under parts white, the lower part of the neck and breast being spotted and sometimes of a yellowish tinge; flanks vermiculated with black. Speculum green and purplish black. Bill black, legs brownish grey. The female is 248 


\section{The Teal}

mottled with brown and buff. The young resemble the female. The male in his eclipse dress, which is worn till late in October or November, resembles the female very closely, more so in fact than is the case with any other species. Length 14.5 ; wing $7 \cdot 25$ in.

\section{THE AMERICAN GREEN-WINGED TEAL}

\section{Nettion carolinense (J. F. Gimelin)}

This species has only occurred three or four times in these islands. The male differs from the Common Teal in having some greyish vermiculated feathers on either side of the breast, and the buffish white lines on the face are very slightly defined. The female cannot be distinguished from our native species. Length 16 in.; wing 7.25 in.

\section{THE BLUE-WINGED TEAL}

\section{Querquedula discors (Linnæus)}

This American species has been taken at least once in the United Kingdom. The male has the throat, forehead, and crown dark lead colour, and a long crescentic patch of white in front of the eye. Cheeks and neck dull lavender grey. Length 16 in.; wing $7 \cdot 25$ in. 


\section{Birds of Britain}

\section{THE GARGANEY}

\section{Querquedula circia (Linnæus)}

This is one of our scarcest species, coming to us as a summer immigrant from April to September, and remaining in a few suitable spots to breed. It is commonest in Norfolk, and may also be found in Hants, Kent, Suffolk, and Yorkshire. Elsewhere its occurrences are rare and only consist of stragglers on migration.

It breeds regularly on the Continent from Sweden southwards, becoming commoner in the east.

The nest is usually placed in a dry and often open situation, where there is but little cover. The eggs resemble those of the Teal, but are rather greener in tint.

The crown and nape of the male are dark brown, with a conspicuous white stripe passing backwards over the eye. Cheeks and neck brown ticked with white. Back dark brown; wing coverts bluish grey. Chin black; breast pale brown, with dark crescentic bars; remainder of under parts white. Vermiculated on the flanks. Speculum green; bill black; legs greenish. Female somewhat similar to Duck of the common Teal, but may be distinguished by the presence of a light stripe over the eye. The feathers of the back are dark with light margins, not barred as in the Teal, while the feathers of the breast are also entirely dark with white margins. Length 16 in.; wing 7.8 in. 


\section{The Wigeon}

\section{THE WIGEON}

\section{Mareca penelope (Linnæus)}

The Wigeon is one of our commonest winter visitors, arriving in large numbers from early in September onwards, and frequenting estuaries, bays, and tidal waters, but rarely wandering far inland. Although feeding also on marine insects and crustacea, it is chiefly a vegetable eater, living almost entirely upon Zostera marina.

In Scotland a good many pairs remain to breed, and during the summer it frequents high moorlands and inland waters. The nest is placed in a tuft of rushes or among heather, and the eggs, usually ten in number, are of a delicate creamy white. The note is a melodious whistle, which may be expressed as "whee you."

The male has the head and neck chestnut, with a broad buff stripe extending backwards over the crown; back grey uniformly vermiculated; throat and upper neck chestnut; breast white, vermiculated on the flanks; shoulders white; speculum green. In the eclipse plumage the head is dark chestnut, grizzled with brown; back brown, with chestnut edgings to the feathers; flanks chestnut; under parts white. The female is dark brownish grey above, lighter on the wing coverts, and white underneath. Length 18.5 in.; wing 10.5 in. 


\section{Birds of Britain}

\section{THE AMERICAN WIGEON}

\section{Mareca americana (J. F. Gmelin)}

One or two examples of this species have occurred in this country at long intervals. It may be distinguished from our Wigeon by the forehead and crown being dull white, the cheeks and neck whitish, speckled with brown, and a green stripe passing backwards from the eye. The female has the head and neck yellowish white, speckled with black. Length 19 in.; wing 10.25 in.

\section{THE RED-CRESTED POCHARD}

\section{Netta rufina (Pallas)}

The Red-crested Pochard, whose nesting home is in South-Eastern Europe, though it also nests sparingly in the Rhone delta and Spain, is only a rare straggler to these islands, and most of the examples have been obtained in Norfolk, where as recently as last year, 1906, a flock of eight appeared, and needless to say were soon all shot.

It is a much larger bird than the Common Pochard, and may be distinguished by its rufous crest, red bill, and legs, though differing also in many other particulars. There are sixteen tail feathers instead of fourteen as in the genus Fuligula. Length 22 in.; wing 10.5 in. 

WIGEON

Mareca penelope 


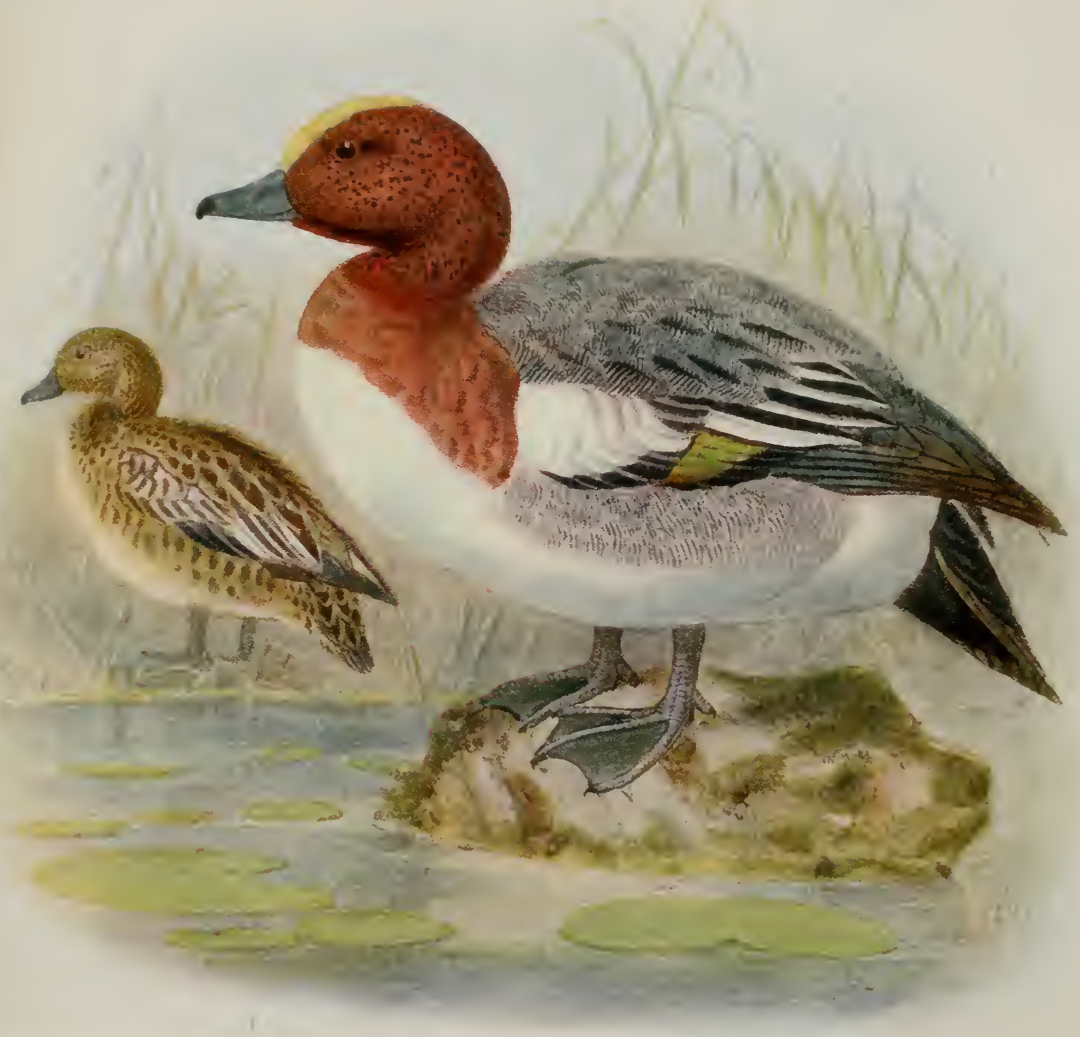





\section{The Common Pochard}

\section{THE COMMON POCHARD}

Fuligula ferina (Linnæus)

With this and the preceding species we come to the second division of the Ducks, which are known as Diving Ducks, in contradistinction to the others which are known as surface-feeders, although quite capable, when alarmed, of diving. Diving Ducks may be recognised by having the legs placed further back on the body, thus rendering their progress on land rather difficult, and by the hind toe being lobed.

The Pochard is chiefly a winter visitor to our shores, occurring not uncommonly in most seasons, but being in some years much more numerous than in others. It chiefly frequents the sea-coasts, feeding on crustacea, molluscs, and a certain amount of marine or aquatic weeds, which it procures almost entirely by diving, but it is by no means exclusively confined to such localities, and is frequently met with on inland waters, provided they are of sufficient size. In spring the majority leave us for their breeding haunts on the Continent, but as a breeding species with us it is on the increase, and may be found in a certain number of favoured localities throughout England and Scotland. In Ireland, where it is fairly abundant during the winter, it has only been known to nest on a few occasions.

The note of the male is a low whistle, but both sexes utter an alarm-note, which may be syllabled as "curre." The nest is always placed in thick cover close to the water's 


\section{Birds of Britain}

edge, and the eggs, which number seven to ten and are fairly large for the size of the bird, are of a greenish drab colour.

The adult male has the head and neck chestnut; the breast and upper parts black, the latter being finely freckled with grey. Under parts greyish white. Bill black, with a broad band of slate grey across it. Legs bluish grey. In its eclipse plumage the head becomes much browner, and the chest is brown, faintly barred with lighter. The female has the head, neck, and chest dull brown; the chin light, the rest of the plumage being like the male but duller. The young resemble the female. Length 19 in.; wing 8.25 in.

\section{THE FERRUGINOUS DUCK}

\section{Fuligula nyroca (Guildenstädt)}

In England this species has been observed on a good many occasions, though some of the instances may have been those of escaped birds. It has also been obtained in Scotland and Ireland. It breeds fairly abundantly throughout Central and Southern Europe, where it is resident.

The male has the head, neck, and upper breast rich chestnut brown, the rest of the upper parts brown, under parts white. The female is duller. It may always be recognised by the white irides. Length $16 \mathrm{in.}$; wing $7 \cdot 75$ in. 


\section{The Tufted Duck}

\section{THE TUFTED DUCK}

\section{Fuligula cristata (Leach)}

This species is the commonest of our Diving Ducks, nesting in increasing numbers on many of our inland waters throughout England, Scotland, and Ireland.

In winter, as is the case with most Ducks, large numbers arrive from abroad, and may be found in shallow bays, estuaries, and inland waters in company with other species.

In food and habits it much resembles the Pochard, and is very good eating after it has been in inland waters for some time.

The nest is placed on rushes, and the eggs, which sometimes number as many as thirteen, are greenish buff, and are said to hatch after about twenty-three days' incubation.

The adult male has the crest, head, and neck purplish black; speculum white. Under parts, including the flanks, snow white. Bill slate grey; eye golden yellow; legs bluish. In the eclipse plumage it becomes much browner, somewhat resembling the female.

The female is sooty brown above and greyish brown below, and her crest is much shorter than that of the male At the end of summer she becomes white round the base of the bill for two or three months, but individuals vary much in this respect. The young resemble the female, and have a whitish forehead. Length $17 \cdot 25$ in.; wing 8 in. 


\section{Birds of Britain}

\section{THE SCAUP DUCK}

\section{Fuligula marila (Linnæus)}

Breeding in the far north of Europe this species visits us in considerable numbers during the winter, feeding on molluses, crustacea, and small fish, which are plentiful on our low, flat, alluvial shores. It goes about in large flocks, and although obtaining much of its food by diving, it is also fond of feeding on the soft ooze left bare by the receding tide. The note is a harsh "scaup."

It is only during the last two or three years that it has been proved beyond doubt to nest in a particular locality in Scotland, where it is strictly preserved.

The nest is placed among stones or rough grass near some pool or mere, and the eggs, which are pale greenish grey, are usually about ten in number.

The male has the whole of the head, neck, breast, and upper parts black, the mantle being thickly vermiculated with white. Under parts white; bill greyish blue; eyes pale yellow; legs bluish. The female has those parts which are black in the male dull brown, and the vermiculations on the back are very scanty. There is a white band round the base of the bill. The young resemble the female, and immature Drakes do not acquire their full plumage for two or three years. Length 19 in.; wing 8.5 in. 

TUFTED DUCK

Fuligula cristata 


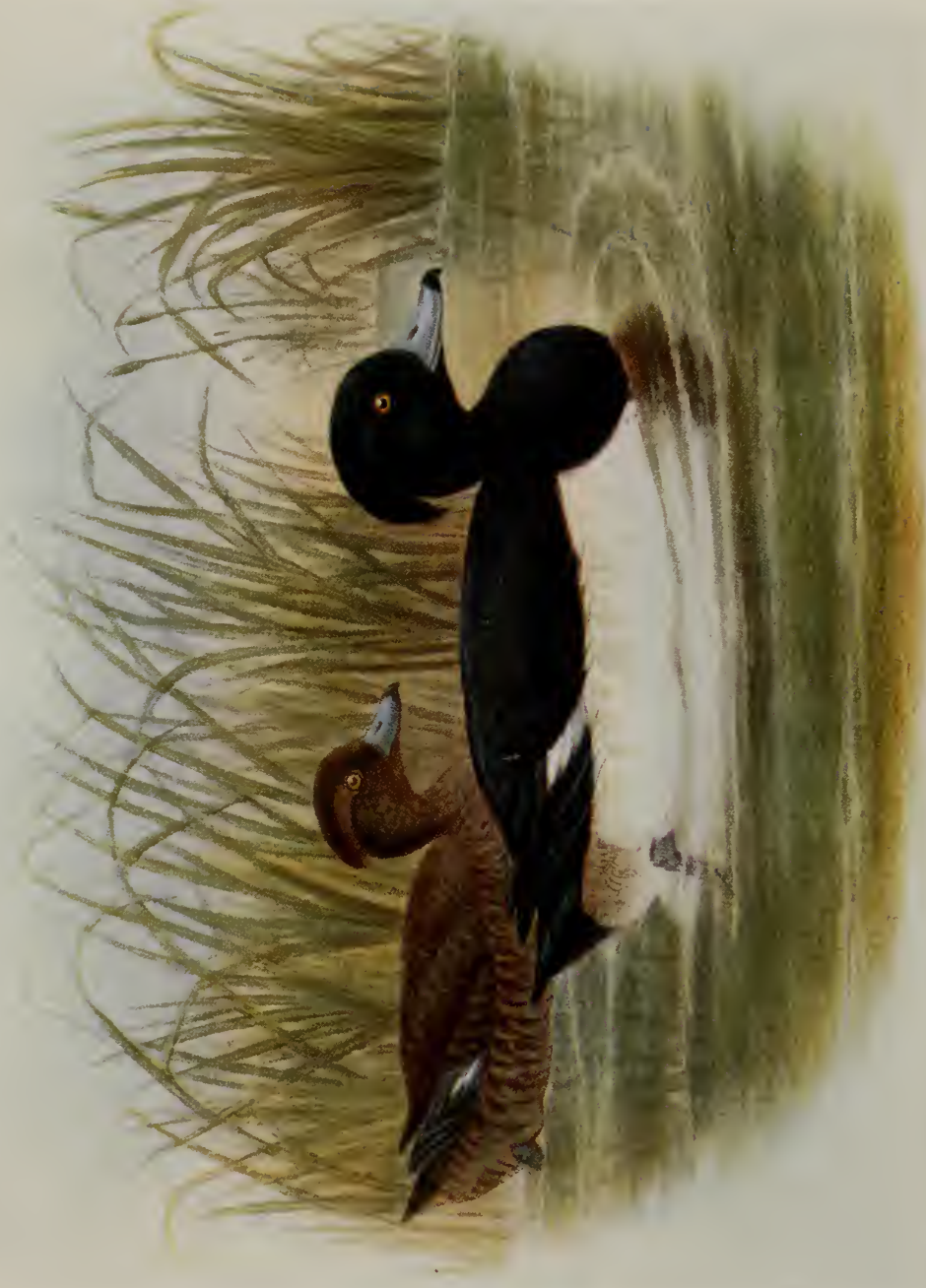





\section{The Golden-eye Duck}

\section{THE GOLDEN-EYE DUCK}

\section{Clangula glaucion (Linnæus)}

Breeding in Northern Europe, this species generally arrives here in October, and may be found sparingly on inland rivers and lakes, as well as in estuaries, becoming commoner in the north. In food and general habits it much resembles the preceding species, but its nest is placed in holes of trees at some distance from the ground, the old hole of a Black Woodpecker being frequently made use of in Scandinavia. The Lapps, in order to obtain the eggs of this and other kindred species, place nest-boxes in the pine and birch woods, the majority of which are tenanted by this species. The eggs, about twelve in number, are bright green. It has never been known to nest with us.

The male has the head and upper neck glossy greenish black, with a conspicuous white oval patch under each eye; the rest of the upper parts, except the scapulars, black; scapulars, a large wing patch, and under parts white. Bill bluish black.' Legs yellow, with black webs. The female has the black parts in the male replaced by greyish brown, and the white wing patch is much smaller in extent. The white spot below the eye is absent. The neck and breast are greyish. The young resemble the female. Length 18.5 in.; wing 8.25 in. 


\section{Birds of Britain}

\section{THE BUFFEL-HEADED DUCK}

\section{Clangula albeola (Linnæus)}

Only two or three examples of this North American species have been obtained in this country. In general coloration it bears a distant resemblance to the Golden-eye, but the male may be recognised by the presence of a large triangular white patch on the head, having its apex at the back of the eye. The female is a dull-coloured bird of various shades of brown. Length 15 in.; wing 6.75 in.

\section{THE LONG-TAILED DUCK}

\section{Harelda glacialis (Linnæus)}

Like many other of our Ducks this is a species which breeds in the north and only visits us in winter. It is fairly common in the north of Scotland and adjoining islands, and there is some evidence that it may occasionally have stayed to breed in the Shetlands. On the east of England immature examples are sometimes shot, especially in severe winters, and the same may be said for the north of Ireland. Over the rest of our islands it is decidedly a rare bird.

Like most Diving Ducks, its food consists of crustaceans and molluscs, and during the winter it is rarely found inland; in the breeding season, however, it frequents small meres and ponds, feeding largely on aquatic vegetation. 


\section{The Long-tailed Duck}

The nest is placed near the water on the ground, and warmly lined with down. The eggs are of a bluish green colour.

In its plumage this species is somewhat peculiar. It assumes in October a black-and-white plumage, in which the head and neck are white except for a brownish grey patch on the cheeks and an oval patch of dark brown on each side of the neck. The upper parts, breast, wing coverts, and central tail feathers, which latter are much elongated, are black. The scapulars, secondaries, outer tail feathers, and under parts white. Bill black, with pinkish band. Legs lead grey. In April, just previous to the breeding season, the white portions of the upper parts are changed, and become of various shades of brown or tawny. The female lacks the elongated tail feathers, is duller, and has the white portions brownish; otherwise she resembles the Drake and undergoes similar changes of plumage. Length, inclusive of tail, 25 in. ; wing 8.8 in.

\section{THE HARLEQUIN DUCK}

\section{Cosmonetta histrionica (Linnæus)}

Iceland is the nearest breeding resort of this species, which nests also in Eastern Siberia, and only three or four examples have occurred on our coasts.

It is a very peculiarly marked Duck ; the general colour above is bluish black, with a white spot at the base of the bill and behind each ear; a white line runs backwards over 


\section{Birds of Britain}

the crown, and another down the sides of the neck. A white ring, bordered with black, encircles the lower neck, and there is another similar one across the breast; the under parts are dark greyish brown. Length 17 in.; wing 8 in.

\section{THE EIDER DUCK}

\section{Somateria mollissima (Linnæus)}

This exclusively Sea-Duck is not uncommon from Northumberland northwards, where it is resident, and breeds in all suitable localities; but over the rest of our coasts it is rare, and only met with occasionally.

In food and habits it calls for no special comment. The nest is placed usually on low rocky islets among the herbage or in crevices of the rocks, but it is sometimes found at considerable distances from the water and often at some height above the sea. Five is the usual number in a clutch, the eggs being large, somewhat pointed, and greenish grey in colour. This bird is famous for the down with which its nest is lined, and on this account is stringently protected in many places abroad. The first two nests are generally taken, the Duck being allowed to hatch her third clutch unmolested.

The Drakes are extremely handsome birds. The head and neck are black, with the exception of a white line running backwards from the crown to the nape, which is green. The cheeks, back, wing coverts, and long sickleshaped secondaries (characteristic of the Eider Ducks) white. Wings, rump, and tail black; breast warm buff. Rest of 260 


\section{The Eider Duck}

under parts black. Bill and legs greenish. In the "eclipse" plumage the whole of the head and white portions of the body (except the wing coverts) become dull brownish black. The female is rufous buff, with darker bars. Length 23 in. ; wing $11 \mathrm{in.}$

\section{THE KING EIDER}

\section{Somateria spectabilis (Linnæus)}

Essentially an Arctic species, and rarely wandering south even in winter, this species is a somewhat scarce visitor to our shores, though a good many examples have been taken, especially in the north. The large raised orange tubercle at the base of the bill and the dark clear-cut $\mathrm{V}$ mark underneath the chin, form fairly distinctive characters by which this species may be recognised, though an imperfect $\mathrm{V}$ mark is sometimes found on the Common Eider. The sickle-shaped secondaries are black and not white, as in the Common Eider. The female is smaller, but otherwise resembles the Common Eider, though on close examination she may be distinguished by the shape and extent of the backward prolongation of the beak sheath. Length 21 in.; wing 10.5 in.

\section{STELLER'S EIDER}

\section{Somateria stelleri (Pallas)}

This is an Arctic species, nesting sparingly in Europe and more commonly on the tundras of Eastern Siberia. It 26I 


\section{Birds of Britain}

is not very rare on the coast of Norway in winter, where many migrate westwards. Two examples only have been obtained in Great Britain.

It is the smallest of our Eiders. The male has the head white, with a bluish black patch across the occiput and on the chin. The rest of the upper parts are bluish black, except the falcate secondaries, which are striped with white. Under parts rufous chestnut. The female, except in size, is very like the Common Eider, but darker. Length 18 in.; wing 8.5 in.

\section{THE COMMON SCOTER}

\section{Edemia nigra (Linnæus)}

This species, except during the breeding season, is almost exclusively a Sea-Duck, spending most of its time some distance out at sea, only approaching the shallower water near the shore for food, and rarely entering bays or estuaries, except under stress of weather.

It is very common round all our coasts, but commonest, perhaps, in the North Sea, where flocks of many thousands may often be seen during the winter months.

The main breeding grounds are the wide tundras of Northern Europe and Siberia, but a few pairs nest in the north of Scotland. The nest is usually placed on an islet in a small lake or mere, and composed of a few tufts of moss and heather lined with down. The eggs, eight or nine in number, are yellowish white in colour. As a rule it is a 262 

COMMON SCOTER

Edemia nigra 


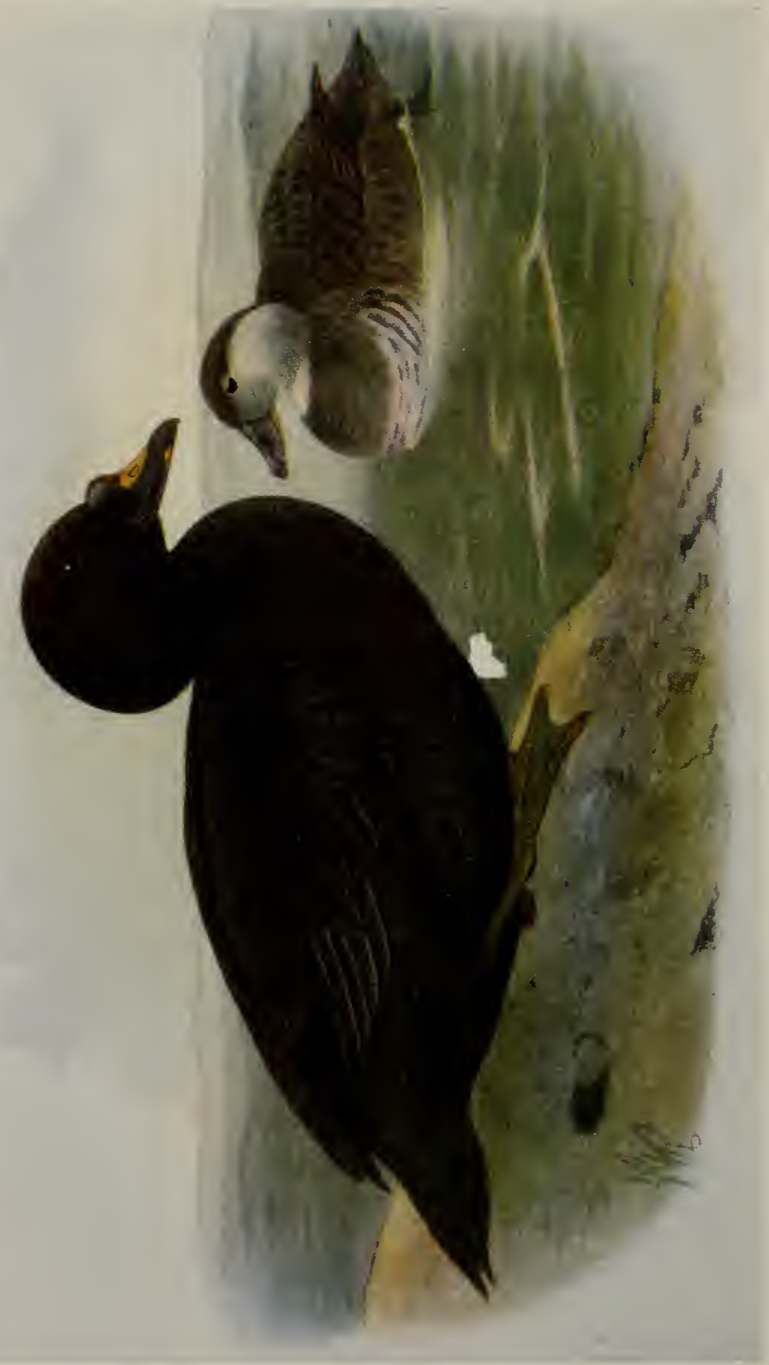





\section{The Common Scoter}

silent species, but during the breeding season the male utters a flute-like "tui, tui, tui."

The male of this species is of a deep black all over, whence it is often locally known as the "Black Duck." Bill black with a bright patch of orange yellow down the centre of the upper mandible. The female and young are sooty brown and lack the orange on the bill. Length 20 in.; wing 9 in.

\section{THE VELVET SCOTER}

\section{Cdemia fusca (Linnæus)}

This species closely resembles the last in habits, but is much scarcer round our coasts and generally keeps farther out to sea.

It is a rather larger bird than the Common Scoter, and of a dense velvety black, with a small white spot behind each eye and a white bar across the wing. The bill is orange yellow, with a large black basal knob and a narrow dark line along the culmen. Legs orange. The female is brown, rather lighter underneath, and has a dull white patch before, and a smaller one behind, each eye. Bill dark. Legs reddish. Length $22 \mathrm{in.}$; wing 10.75 in. 


\section{Birds of Britain}

\section{THE SURF SCOTER}

\section{Edemia perspicillata (Linnæus)}

This North American species has on several occasions occurred on our coasts.

The male may be at once distinguished from the other Scoters by the presence of a broad patch of white on the forehead and another on the nape. In the female the nape patch is present though often indistinct. There is no white bar across the wing. Length 21 in.; wing 9.5 in.

\section{THE GOOSANDER}

\section{Mergus merganser, Linnæus}

The Goosander is the first of the three species of "Sawbills" that are found in this country. Unlike other Ducks, the bill is moderately long and narrow, and both mandibles have a very rough toothed surface enabling them easily to secure and hold their prey, which consists entirely of fish. They are all expert divers. On the east coast of England this species is not uncommon during the winter months, frequenting estuaries and freshwater lakes, but in the south and west it is of irregular occurrence. In Scotland it is known to nest in a few localities, but on the west coast and in Ireland it is decidedly rare. The nest is placed down a hole among rocks, or in a tree, and in Sweden and Lapland 264 


\section{The Goosander}

it makes extensive use of the nest-boxes put up for it and other species by the Lapps. The eggs, which may be as many as thirteen in number, are creamy white. The note is a very harsh "kaar," and when swimming this bird is not unlike a Cormorant in general outline. When wounded it will always attempt to escape by diving.

The male has the head and neck dark glossy green; back and scapulars brown, passing to grey on the rump; wing coverts white; lower neck and under parts creamy white, tinged with pink in the living bird. Bill and legs red. The female is rufous brown ou the head, greyish on the upper parts and flanks, and buffish white below. She is rather smaller than the male. The young resemble the female. Length $25 \mathrm{in}$; wing $11 \mathrm{in.}$

\section{THE RED-BREASTED MERGANSER}

\section{Mergus serrator, Linnæus}

Nearly allied to the preceding species, the Merganser is fairly common round our shores in winter, and nests in considerable numbers in Scotland, both on lakes and tarns, as well as on the coasts in the north and west. In Ireland it is a very common resident, breeding especially abundantly on the west coast. In habits and food it resembles the Goosander, but is less frequently found inland and far more partial to the sea than that species. The nest is not placed in a hole but in thick cover at no great distance from water; the eggs, generally about ten in number, are of a pale 


\section{Birds of Britain}

greenish drab and are never of that creamy tint which distinguishes those of the former species. In these Ducks the male apparently helps the female in attending on the young and in catching the small fry on which they live.

Although smaller, this species is not unlike the Goosander ; the male may always be recognised by his reddish breast, streaked with black; the wing patch is white, barred with black, and on the breast at the point of the wing there is a conspicuous tuft of white feathers, with black margins; the long falcated inner scapulars are black. The female has a distinct black bar across the wing patch, but in other respects, except size, closely resembles the Duck Goosander. Length 24 in.; wing 9.5 in.

\section{THE SMEW}

\section{Mergus albellus, Linnæus}

This species, the smallest and scarcest of the Sawbills, only comes to us in the winter, its breeding haunts being near the limit of tree growth throughout Northern Europe. It may be found on inland rivers and lakes, as well as in sheltered bays and estuaries on the coast. Immature examples with a red head, known as "Red-headed Smews," far out-number the adults, and old males in full plumage are rarely seen.

This is one of the species that occupies the boxes in Sweden and Lapland, and the discovery of its eggs, fifty years ago, was due to the energy and perseverance of an English266 



\section{RED-BREASTED MERGANSER}

Mergus serrator 


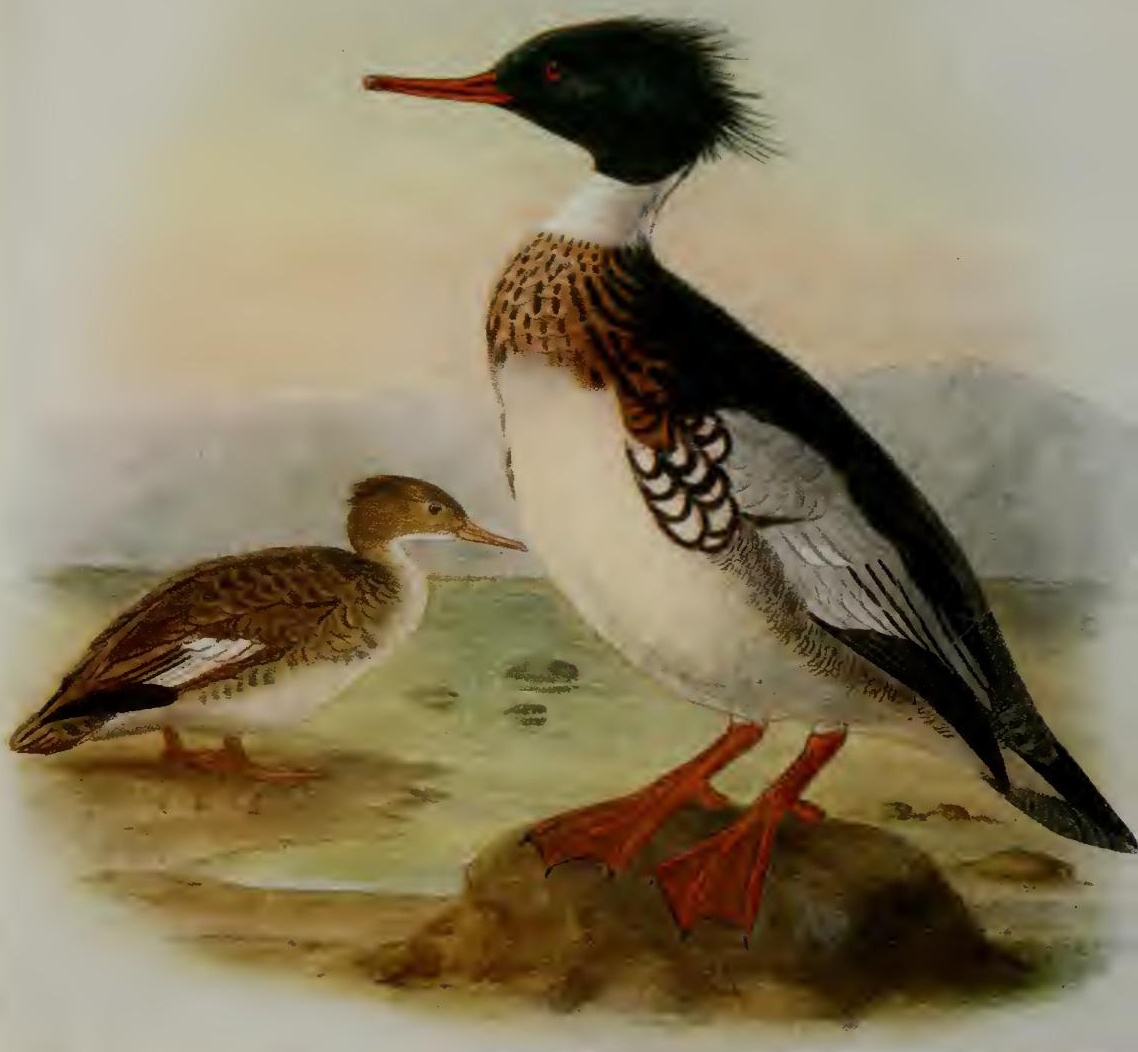





\section{The Smew}

man, John Wolley, who, after four years' search, succeeded in obtaining three eggs together with a sitting bird. The eggs are cream coloured and not unlike those of the Wigeon, but they are slightly smaller.

The adult male is entirely white, except for the mantle and quills, which are jet black. The rump, upper tail coverts, and tail are bluish grey, and the flanks delicately vermiculated with the same colour. Stretching half-way across the breast is a narrow black bar, and a shorter but broader one starts a little farther back. There is a black patch between the bill and the eye on each side, and another high up on the occiput joining its fellow on the opposite side, this black crescent being broken by the overlapping of the slightly elongated feathers of the head.

The "eclipse" plumage somewhat resembles that of the immature male, from which it may always be distinguished by the mantle remaining black. The female is smaller; head and neck reddish brown; remainder of upper parts and breast ashy grey; under parts white. Length 17.5 in.; wing $7 \cdot 6$ in.

\section{THE HOODED MERGANSER}

Mergus cucullatus, Linnæus

This is a North American species, which has only very rarely visited our shores. It may be distinguished by a semicircular crest or hood over the head, the posterior half of which is white, with a dark edge. The general colour 


\section{Birds of Britain}

is dark brown above and white below. Length 19 in.; wing $7 \cdot 75$ in.

\section{THE WOOD PIGEON}

\section{Columba palumbus, Linnæus}

Whereas in the case of many species one has to record their increasing scarcity and approaching extermination as far as these islands are concerned, with the Wood Pigeon the case is very different. Nesting in the woods throughout the country, where, owing to strict preservation, trespassers are forbidden and raptorial birds shot, this species has of late years increased with amazing rapidity and may be found in winter in flocks of thousands, which often do considerable damage to the crops. Although as a rule very shy and wary, it becomes in towns, where it is unmolested, absurdly tame, and it may now be found in the London parks and squares disputing with the omnipresent Sparrow the crumbs of bread thrown out by passers-by. It is curious and interesting to note that it is very conservative in its habits, rarely settling on any of the buildings like the wild domestic Pigeons, which are descended from the Rock Dove, but always keeping to the trees and gardens, leaving its tame relative in undisputed possession of the streets and buildings. On one occasion at least it deigned to avail itself of civilisation, for a nest was recently found in one of the parks composed almost entirely of ladies' hairpins.

The nest is usually placed on a tree, but sometimes in bushes or hedgerows. It is made of twigs laid loosely on 268 


\section{The Wood Pigeon}

each other, and is such a flimsy structure that one would never imagine it capable of forming an efficient nursery for so large a bird. Two eggs only are laid, which, as with all Pigeons, are pure white. Two or three broods are often reared in the season, both sexes taking their turn at incubation and rearing the young:

Pigeons when first hatched are covered with coarse yellowish down and are very helpless; they are fed for the first ten days on a sort of soft curd known as Pigeon's milk, which is secreted in the crop, or is, as has been stated, the secretion of two glands placed on each side near the crop, but this latter point requires confirmation. They are fed by regurgitation, the young bird inserting its beak into that of the parent.

The note of the Wood Pigeon is a soft melodious "cooroo, coo, coo." When courting he expands his tail, blows out his crop, and holding his head high in the air utters his coo; he then bows, and raises his expanded tail. His hen, who usually shows but little enthusiasm over the display, has probably moved a little farther off, and the display ends with an awkward hop towards her.

The flight is rapid and sustained, but in the nesting season, and occasionally at other times, an upward soaring flight is indulged in over their nesting home. Its food consists chiefly of grain, seeds, beechmast, and acorns; but at certain seasons, especially when the snow is on the ground, large quantities of green food are eaten, tender turnip tops being much sought after.

The adult is a delicate bluish grey all over, having a violet green metallic patch on the sides of the neck, bounded 269 


\section{Birds of Britain}

on each side by a patch of white. The breast is a rich vinous purple. Tail and wing feathers nearly black. Bill yellow; legs red. The sexes are alike; and the young resemble their parents, but are duller in colour and lack the metallic and white patch on the sides of the neck. Length 17 in.; wing 10 in.

\section{THE STOCK DOVE}

\section{Columba œnas, Linnæus}

The Stock Dove is rather smaller and considerably less common than the previous species, but is nevertheless by no means uncommon in England, and has greatly increased of late years, especially in Scotland. In Ireland it is still a rare and local species. The name "Stock Dove" is not due, as many erroneously suppose, to its being the race from which our domestic Pigeons spring, but to its habit of nesting in the stocks and boles of old timber. Such places are, however, by no means exclusively used, for it also nests in caves, ledges of cliffs, and rabbit-burrows. Otherwise its habits are not materially different from those of the Wood Pigeon. As a rule it goes about in pairs, and large flocks are never met with, even when migrating from its more northerly breeding quarters.

It is a smaller and duller bird than the Wood Pigeon, lacking the white spot on the neck; while the vinous purple on the breast is not nearly so bright. There are traces of two indistinct wing bars. Length 13.5 in.; wing 8.8 in. 

STOCK DOVE

Columba anas 


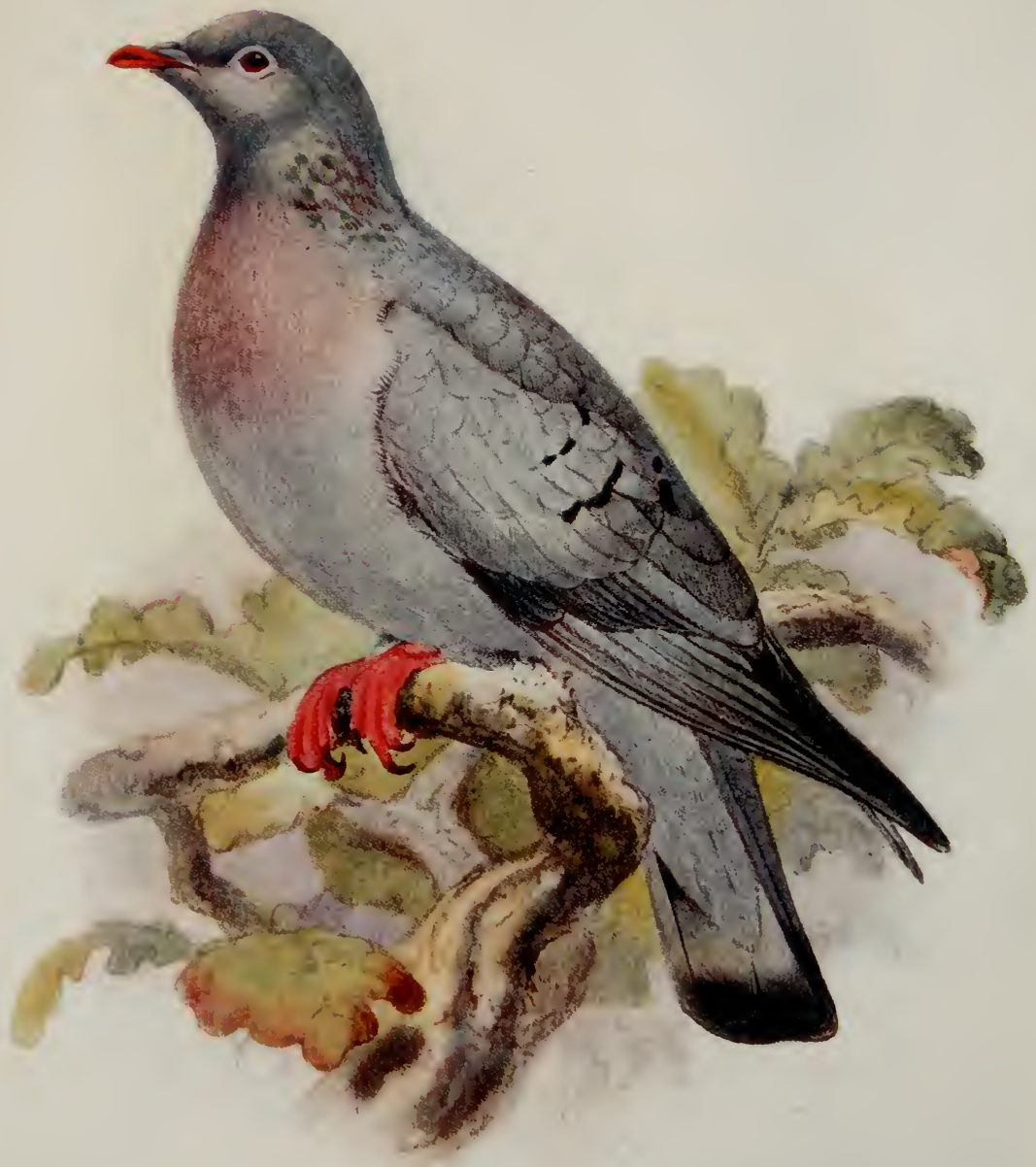





\section{The Rock Dove}

\section{THE ROCK DOVE}

\section{Columba livia, J. F. Gmelin}

The Rock Dove is the original species from which most of our domestic varieties have been derived. It is only on the wildest and most inaccessible parts of our coast that this species can now be found in its pure state, as in all the more inhabited portions it has become interbred with feral domestic birds. It is a resident with us, breeding in caves along the coast, although on the Continent it also frequents inland and mountainous regions. The nest, built of sea-weed, is placed on a small ledge near the roof of a cave, those into which the sea comes up with each tide being chosen by preference.

They breed very early, and at least two broods are reared in a season, and in small caves which are only tenanted by one pair, two nests may often be found and are used alternately, the second clutch being usually laid before the young of the first brood are ready to fly. It is worthy of note that in this and many other species, where for the young to move from the nest before they are fledged would mean instant death, they remain actually in the nest itself till fully fledged, and do not take their first flight till they are almost as strong on the wing as the old birds.

This habit is in marked contradistinction to Rooks and many other small birds that leave the nest and perch on the branches round, long before they can fly. The Gulls 


\section{Birds of Britain}

form also another example, as by nature they would and do run from the nest, if the nest is on the ground, but if placed on a narrow ledge they hardly move from it until fully Hedged.

In habits this bird resembles the other Pigeons; though its method of courting, which must be well known to most people, is slightly different. The male has a curious habit, shared also by the Stock Dove, of driving the hen for a few days before she lays. On these occasions his whole time is spent in keeping her on the move, and he never lets her settle or rest for a minute except on the nest.

The sexes are alike, and pale grey all over, except the rump, which is white. Across the wing are two distinct and clear-cut black bars, while the metallic patch on either side of the neck is rather more extensive than in the Stock Dove. Length $14 \mathrm{in}$; wing $8.8 \mathrm{in.}$

\section{THE TURTLE DOVE}

Turtur communis, Selby

This small species is only a summer immigrant with us, arriving early in May and leaving again for its winter home in Southern Europe and Africa in September. In England it is a common and widely distributed species, but in Scotland and Ireland it is rare, only occurring on migration, though it may sometimes have nested in the former country.

It frequents woods, coppices, and tall hedgerows, con- 




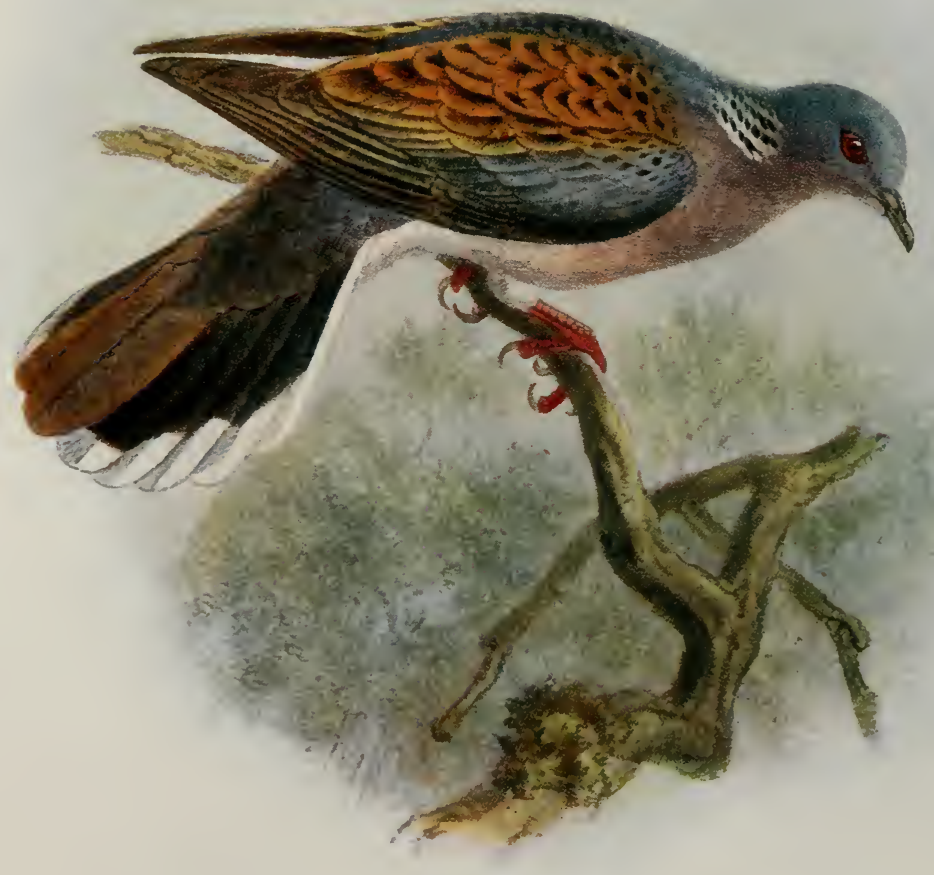





\section{The Turtle Dove}

structing a frail nest of twigs on which to lay its two white eggs. It feeds on seeds and grain, gathering in large flocks in the open fields in autumn before migrating. The note is a prolonged purring "coo."

The male has the head, nape, wing coverts, rump, and flanks bluish ash, and a patch of black feathers tipped with white on each side of the neck. Rest of the back dark brown with broad rufous edges to each feather. Throat and breast pale vinaceous, rest of under parts white. Tail feathers dark brown, tipped with white. Length 11.25 in.; wing $6 \cdot 8$ in.

A single example of the Rufous Turtle Dove (Turtur orientalis, Latham) was obtained near Scarborough. It inhabits India and the East, and hardly differs from our common species, but may be distinguished by its slaty blue rump.

\section{PALLAS' SAND GROUSE}

\section{Syrrhaptes paradoxus (Pallas)}

The real home of this species is east of the Caspian, spreading through Asia to Mongolia and Southern Dauria. On several occasions during the last fifty years Europe has witnessed an extraordinary immigration of these birds, which spread westwards in countless numbers. The first wave to reach our islands arrived during the latter half of 1859 , and four years later a larger invasion took place, the birds spreading throughout the country. The largest 


\section{Birds of Britain}

immigration, however, took place in 1888 , in which year several pairs nested with us in Yorkshire and other places. In 1889 a special Act of Parliament was passed for their protection, but it came too late, for by that date they had all been slaughtered or had left for more peaceful localities.

The eggs are two in number and of a warm stone buff colour, with purplish blotches; they are laid in a depression in the ground with no attempt at a nest. Their food consists almost entirely of seeds and grain. The general colour is yellowish buff, greyer on the head and barred on the back with black. Under parts greyish buff, mottled on the gorget and banded on the belly with black. Feathers of the vent and feet white. The female and young are duller and more uniformly spotted. Length $14 \cdot 75$ in.; wing $9 \cdot 1 \mathrm{in.}$

\section{THE CAPERCAILLIE}

Tetrao urogallus, Linnæus

Although originally an inhabitant of Great Britain, this species became extinct over a hundred years ago from causes which are by no means clear. In 1837 it was introduced into Perthshire and a few other districts in Scotland, where it has increased largely, and is at the present time gradually spreading southwards through the pine, oak, and birch forests.

It is essentially a forest-haunting species, rarely, if ever, 274 


\section{The Capercaillie}

wandering far from the woods, where its call of "peller, peller, peller," may be continually heard during the spring months, and sometimes again in autumn.

Like most game birds, it is polygamous, and an old cock is very jealous of his hens, savagely attacking other males that oome near him. When 'courting he performs various evolutions, drooping his wings and erecting his tail, and calling out vigorously at the same time. Their food consists chiefly of various seeds and berries, and in their season the tender shoots of the Scotch fir.

The nest is merely a "scrape" in the ground, generally at the foot of a tree, and the eggs, some twelve in number, are reddish brown spotted and blotched, with darker shades of the same colour. The young feed largely on insects and worms, and are especially fond of ants. The male takes no part in the incubation or tending of the young.

The male is very dark grey on the upper parts, breast glossy green, and the remainder of the under parts black. The feathers of the chin and throat are elongated. Length 36 in. ; wing 16 in.

The female, who is much smaller, is brownish all over, mottled and barred with buff and white. Length about 26 in.

\section{THE BLACK GROUSE}

Tetrao tetrix, Linnæus

On the moors and woods of Scotland this is a common species, and it is also found locally in a few places in the 


\section{Birds of Britain}

west of England, but in some of its other English haunts, notably the New Forest, it has died out.

Like the Capercaillie, they are polygamous, and gather together in spring, the cocks fighting and showing off in a variety of evolutions to the hens. Eventually each cock retires with his hens, and breeding commences in earnest. The nest is merely a scrape in the heather or on the outskirts of a wood, and the eggs, generally ten in number, are yellowish, spotted with reddish brown. The young feed chiefly on insects, but when adult, grain, berries, and the tender shoots of many plants constitute their diet. In autumn they visit the harvest-fields in large numbers at daybreak and dusk. The adult male is bluish black all over, with white under tail coverts and a white wing bar. Length 22 in.; wing 10.5 in. The female, usually known as the "Greyhen," is of a warm brown, barred and marked with black.

\section{THE RED GROUSE}

\section{Lagopus scoticus (Latham)}

This is the only exclusively British species which is found nowhere else-if we except the local races of many of the smaller birds, which can only be distinguished on a very close examination. Our Grouse differs from the "Ryper" of Norway, which is its nearest ally, by its black primaries, and in the fact that it does not assume a white dress in winter.

It inhabits moorlands from the limit of heather growth 276 

RED GROUSE

Lagopus scoticus

Male (left). Female (right) 


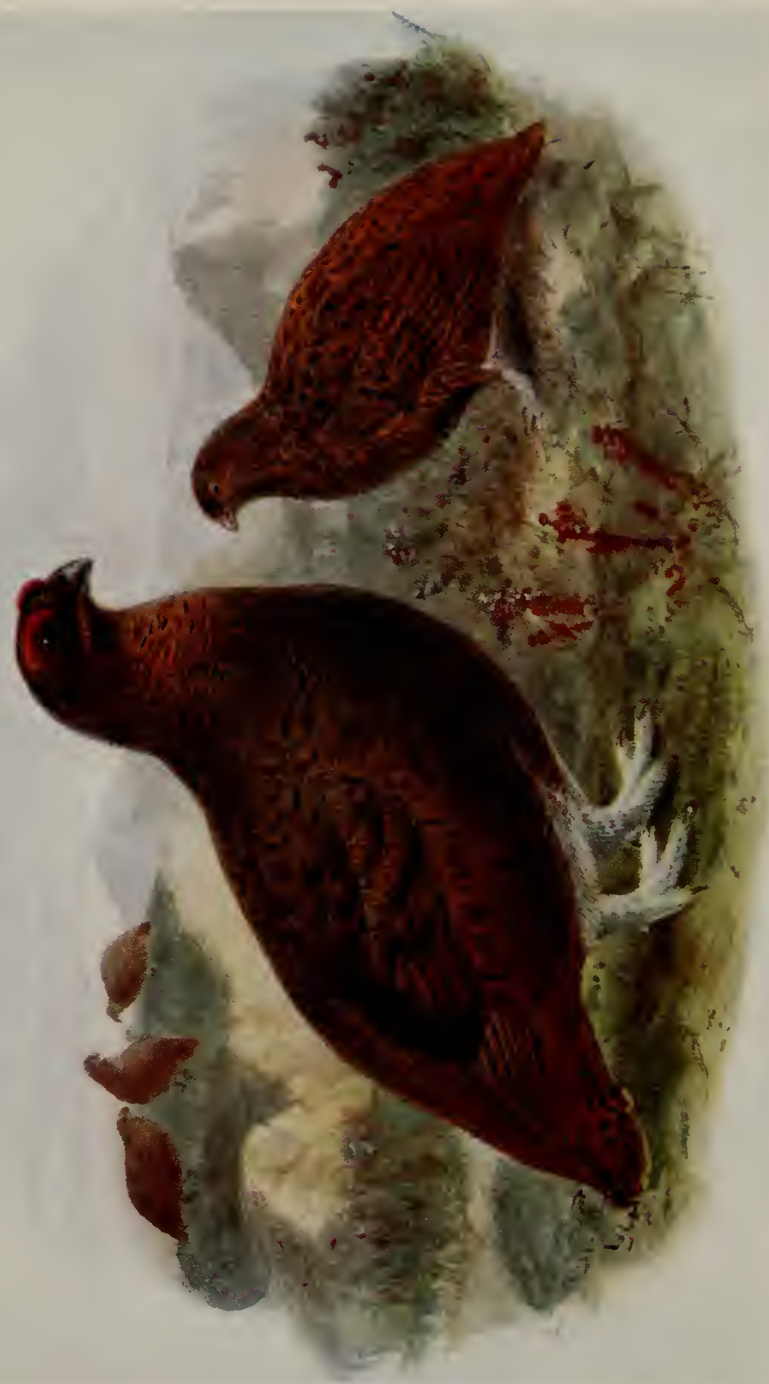





\section{The Red Grouse}

to the coast-line, and is generally and widely distributed throughout Scotland and the northern half of England, as far south as Glamorganshire in Wales, but on the east it does not occur south of the Trent. In Ireland it is fairly well distributed, but not so common as in Scotland.

Unlike the two former species, the Red Grouse is strictly monogamous, pairing very early in the season, when his callnote of "go back, go back," may frequently be heard. The nest is a scrape among the heather, no materials being added. Ten to twelve eggs form the usual clutch; they are very handsome, being of a pale ground colour, thickly and profusely marked with dark reddish brown.

The male waits on the hen during incubation, warning her of the approach of danger with a sharp "kok, kok, kok." Their food consists of various seeds and berries, together with the leaves and shoots of plants, and the tips of ling and heather; in autumn they also visit the harvest-fields.

The young are fed on insects. This species keeps, as a rule, in family parties, only packing together during severe weather in the less exposed places, but where they are much driven and shot, they are often found in large flocks.

They vary considerably in their plumage, about which more information is needed. The male is dark brown, barred with reddish, and is often nearly black on the breast and whitish on the vent. The female is similarly coloured, but lighter. Length 16 in.; wing 8.4 in. 


\section{Birds of Britain}

\section{THE PTARMIGAN}

\section{Lagopus mutus (Montin)}

Closely allied to the Red Grouse, the Ptarmigan is found on the higher slopes of the Scottish Highlands from Perthshire northwards. Elsewhere in these islands it is unknown.

In habits and food it hardly differs from the Grouse; the nest is placed among stones on the ground, and the eggs, except in being rather smaller and slightly lighter in colour, are undistinguishable from those of that species.

The Ptarmigan passes through a complicated plumage cycle, having three distinct plumages; in summer the male is dark brown, vermiculated with grey on the head, breast, and upper parts. Wings white, tail dark brown, belly white. The female is pale yellowish brown, barred with dark brown. In autumn the upper parts become slate grey, finely vermiculated with dark brown, and in winter both sexes are entirely white, except that the male has black lores. Length $14.5 \mathrm{in}$; wing $7.75 \mathrm{in}$.

Most of the so-called "Ptarmigan" in our poulterers" shops are the Willow Grouse or "Ryper" from Scandinavia and Russia. They may be distinguished by their larger size and the absence, in the males, of the black lores. 


\section{The Pheasant}

\section{THE PHEASANT}

\section{Phasianus colchicus (Linnæus)}

This species is so well known that we need occupy but little space in dealing with it.

It is now generally distributed throughout our islands, and was first introduced into England, to which it is not an indigenous bird, from a district of South Russia near the Black Sea, at some period previous to the Norman Conquest. 'To Scotland and Ireland it was imported during the latter half of the sixteenth century. During the last hundred years another species, the Chinese Ring-necked Pheasant, has been imported, and has so interbred with the original birds that the pure Colchian Pheasant is hardly ever shot at the present day.

The Pheasant is a woodland bird, roosting on trees and roaming in the fields during the day in search of its food, which consists chiefly of grain and seed, but during the summer months many insects are eaten. It is polygamous, and the nest is placed in thick cover on the ground; ten to twelve pale brown eggs form the usual clutch. The hen is said to be a bad mother and to desert her eggs if disturbed, but this has probably been largely brought about by the artificial conditions under which they are now kept.

In spite of their size and proportionately short wings, they are strong fliers, and when well on the wing progress at a considerable pace; if possible, however, they generally 


\section{Birds of Britain}

try to escape by running and squatting low on the ground until closely approached, when they rise with their wellknown "whirr." The male has a short "crow," accompanied usually by a rattling of the wings.

No description of this well-known bird is needed. The Chinese form only differs from the original breed in having a white ring round the neck.

\section{THE PARTRIDGE}

\section{Perdrix cinerea, Latham}

In England the Partridge is an exceedingly abundant species, but in Scotland and Ireland, although,well distributed, it is much more local. It is strictly monogamous, pairing very early in the year, but nesting operations are rarely commenced before the end of April or early in May. The nest is a scrape in some hedge bottom, or on a grassy bank, and often contains as many as fifteen to twenty eggs, which are somewhat pyriform in shape, and of a uniform olive brown in colour. This species chiefly inhabits the open cultivated districts, where it feeds on various seeds and grain, but in summer insects are largely consumed, and the young are at first fed on them exclusively.

During the early autumn and winter the various families keep together, forming the well-known "coveys," but if the weather be severe these birds will "pack" in large flocks like Grouse.

A description of this well-known bird is hardly necessary 280 

PARTRIDGE

Perdix cinerea 


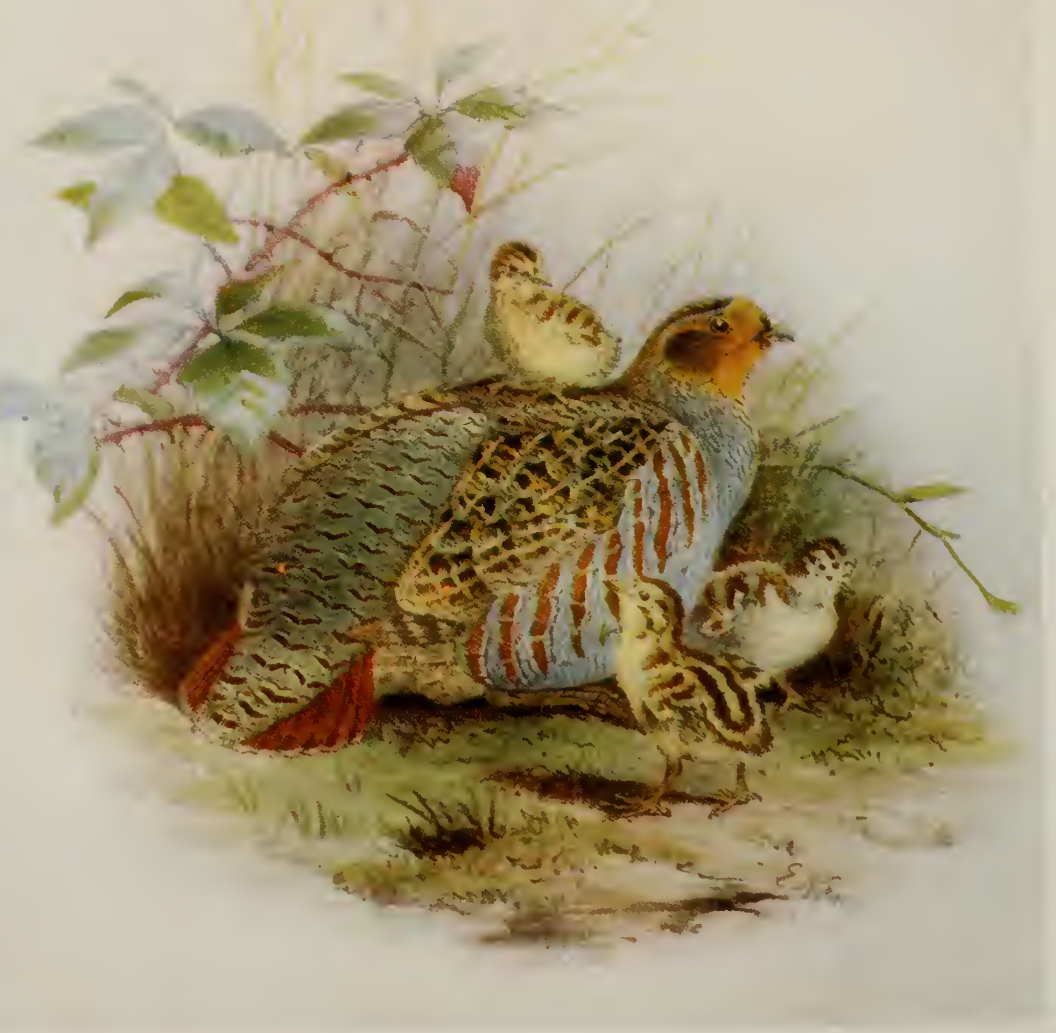





\section{The Partridge}

The male differs from the female in the brighter yellowish chestnut of the head and greyer neck, and the wing coverts are longitudinally striped with buff in the male, but in the female they are barred.

In young birds the general tone of the plumage is paler, and the feathers have a median buff longitudinal stripe. Length 12.5 in.; wing 6 in.

\section{THE RED-LEGGED PARTRIDGE}

\section{Caccabis rufa (Linnæus)}

This species has been introduced into this country at various times from 1770 onwards, and is now well established in several districts. Its home on the Continent is the east and south of France, Spain, and North-western Italy, where it inhabits dry and mountainous districts. In this country it can only be called common in the East Anglian counties, though it is also found on both sides of the Thames valley and in some parts of the Midlands. The damp climate of the west does not suit it, and attempts to introduce it into Scotland and Ireland have failed.

In food and habits it is somewhat similar to the Common Partridge, but its habit of running instead of getting on the wing renders it less desirable as a sporting bird, and its flesh is decidedly inferior. It lays its eggs in banks or under hedges, well concealed by thick cover, without any attempt at a nest beyond a slight scrape. The eggs are yellowish white, speckled with brown, and are slightly larger 


\section{Birds of Britain}

than those of the Common Partridge. The note is a harsh "clink, clink, clinkar," and the male assists the female in rearing the young.

They are not quite so gregarious as the preceding species, and old males, except during the breeding season, frequently lead a solitary existence.

The sexes are alike in plumage, but the male has a blunt spur. The throat and cheeks are white, bordered with black. Sides of neck and breast grey, spotted with black. Crown grey; stripe above the eye white. Rest of upper parts warm rufous brown. Under parts fawn colour; flanks grey, boldly barred with black and chestnut. Bill and legs deep coral red.

The young are brown on the throat and breast. Length 13.5 in. ; wing 6.22 in.

\section{THE QUAIL}

\section{Coturnix communis, Bonnaterre}

This species is only a summer visitor to this country, though examples have been known to spend the winter with us. Never very abundant, it has of late years become decidedly scarcer, and can now only be considered an uncommon and local bird.

Delighting chiefly in dry, broken, uncultivated land, it becomes scarcer in the north, but has been known to nest as far north as Caithness. The nest is a "scrape" in the grass, and the seven to twelve eggs are yellowish white 282 


\section{The Quail}

blotched with umber brown. The male has a melodious callnote, which may be syllabled as "clerk, lik, lik," to which the female answers with a soft "peu, peu." The food consists of grain, seeds, and insects, and at the times of migration this bird becomes exceedingly fat and very good eating. The Quails that are found in our markets are usually snared in Italy during the spring migration, and used to be sent alive to this country, but they are now killed and sent dead. It was a migration of this species that supplied the Children of Israel with food in the desert, and large flocks still pass through Palestine yearly on migration.

The Quail is not unlike a small Partridge, and is of a uniform sandy brown on the upper parts, with paler shafts to the feathers. The chin and throat are white, with two brown crescentic bars, and sometimes a brown streak down the centre. The breast is buffish and the under parts white. This species shows a certain amount of variation in minor details of plumage. Length $7 \mathrm{in}$.; wing $4.4 \mathrm{in}$.

\section{THE LAND-RAIL}

\section{Crex pratensis, Bechstein}

Grass lands throughout England, Scotland, and Ireland form the summer home of this well-known and abundant species. It is a migrant, arriving towards the end of April and leaving our shores again in September, though a few individuals occasionally remain and pass the winter in Ireland and some of the western counties of England. It 


\section{Birds of Britain}

is always more abundant in the west, and during the last few years has become comparatively scarce and local in our eastern and south-eastern counties.

The Rails are birds of poor flight and skulking habits, rarely taking to their wings unless hard pressed, and even at such times flying but a short distance with legs hanging down, and soon dropping again into the nearest cover. Immediately on his arrival the male Land-Rail, or Corncrake as it is often called, utters his well-known crake-a harsh "craak, craak," repeated with monotonous frequency, especially during the long summer evenings and again before dawn.

The nest is placed in dense cover in the middle of some grass- or corn-fields ; it is a deep "scrape," generally hollowed out by the cock, and lined with bents and grass. Eight to ten eggs are the usual clutch; they resemble those of the Missel Thrush, being greenish white, spotted and blotched with red, brown, and greyish. The male, who takes no part in the incubation, is very attentive to his mate, bringing her delicate tit-bits and accompanying her when she leaves the nest. Their food consists of worms, slugs, snails, and other insects, as well as grain and seeds, so that it is practically omnivorous. When the young are hatched the "craking" ceases, and both parents brood and tend the young. These when first hatched are jet black, and become fully feathered in about a month or five weeks, their wing feathers being the last to grow. Although they can run and leave the nest as soon as hatched, they do not feed themselves for some days, but take all their food from their parents' beaks. If the first clutch of 284 

LAND - RAIL

Crex pratensis 


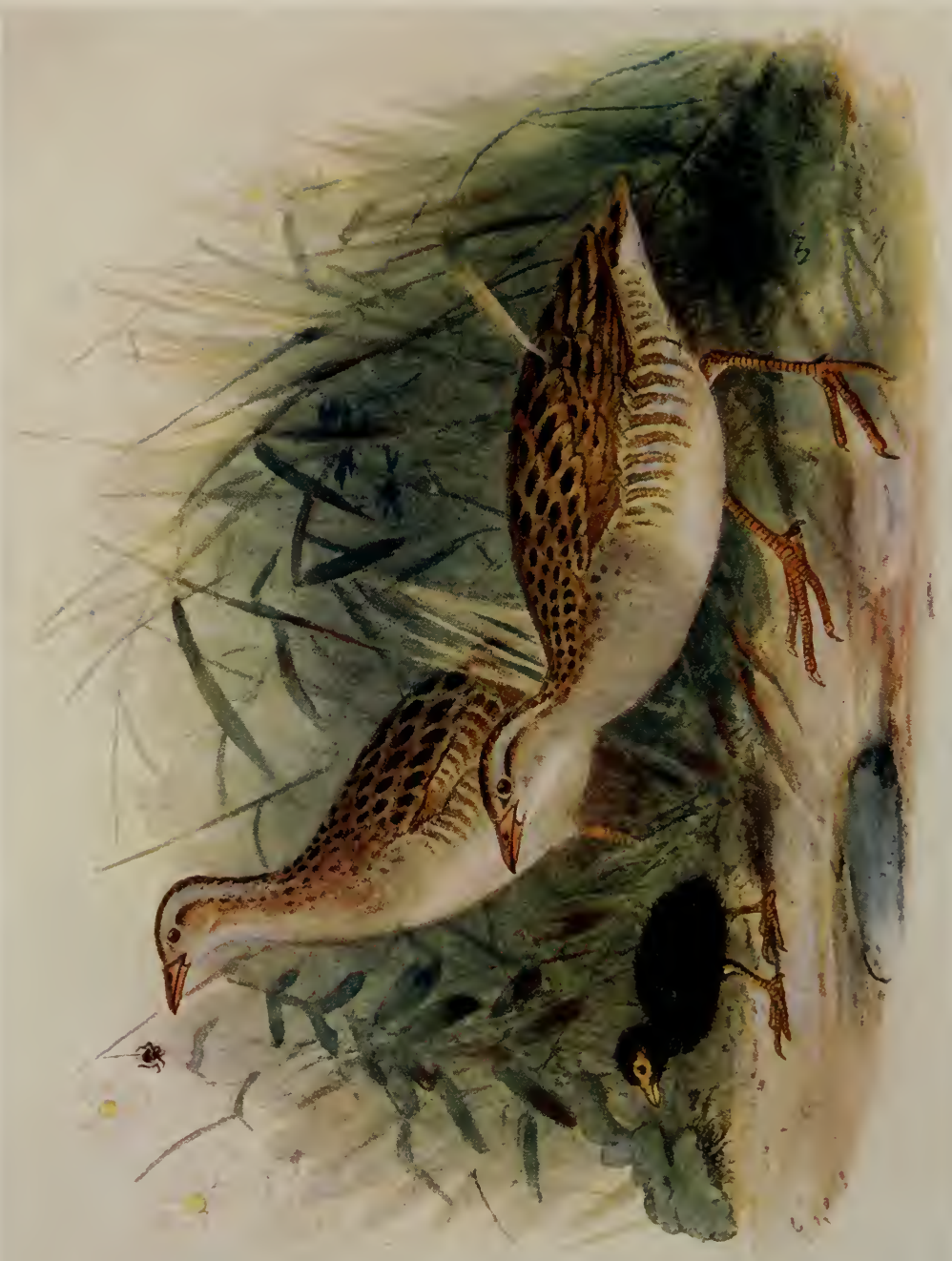





\section{The Land-Rail}

eggs is destroyed the craking recommences, and a second clutch is laid.

During the autumn moult this species, in common with the others of its family, casts all its primaries at once, and is for about ten days incapable of flight.

In winter it is found throughout Africa as far south as Cape Colony.

In winter the sexes are practically identical, the upper parts being dark brown, with rufous edgings to the feathers : wing coverts chestnut; throat and abdomen white; breast pale brown; flanks barred with brown and buff. After the spring moult the male has part of the head, throat, and breast ash grey. The female is greyer than in winter, but much browner than the male, especially on the breast. The young resemble the adults in winter, but the rufous margins are much broader. Length 10.5 in.; wing $5 \cdot 25$ in.

\section{THE SPOTTED CRAKE}

\section{Porzana maruetta (Leach)}

This is a smaller species than the preceding, and is found in marshes and swamps. They visit us in small numbers every summer, and remain to breed in suitable localities far more commonly than is usually supposed. It is, however, a very skulking species and its only note is a low "kwit, kwit," so that it is seldom either seen or heard, and the few birds that are killed on migration are the only evidence we usually 285 


\section{Birds of Britain}

get of its presence. In Scotland it is rarer, but has been found nesting in Elgin and has occurred on migration in the Shetlands. In Ireland it is a yearly immigrant, but only a few nests have been found. Except in its liking for damper places, it resembles the Corncrake in most of its habits.

The nest is placed in a reed-bed or tussock of sedge, often entirely surrounded by water. It is formed externally of coarse weeds and lined with finer materials. The eggs, usually eight to ten, are olive buff, spotted and flecked with reddish brown. The young when first hatched are black and take to the water readily, swimming about with the ease of young Moor-hens.

The male is greenish brown on the upper parts, the feathers having darker centres as well as a few small white spots; breast brown, spotted with white; rest of under parts grey; flanks barred with brown. This bird shows no great differences in plumage, the sexes and young being much alike. Length 9 in.; wing 4.5 in.

\section{THE LITTLE CRAKE}

\section{Porzana parva, Scopoli}

The little Crake is a migrant breeding in Central Europe. To Great Britain it is a very rare straggler, and has only been taken about a dozen times, and only one instance is noted from both Scotland and Ireland.

It is a rather smaller bird than the preceding species, 286 




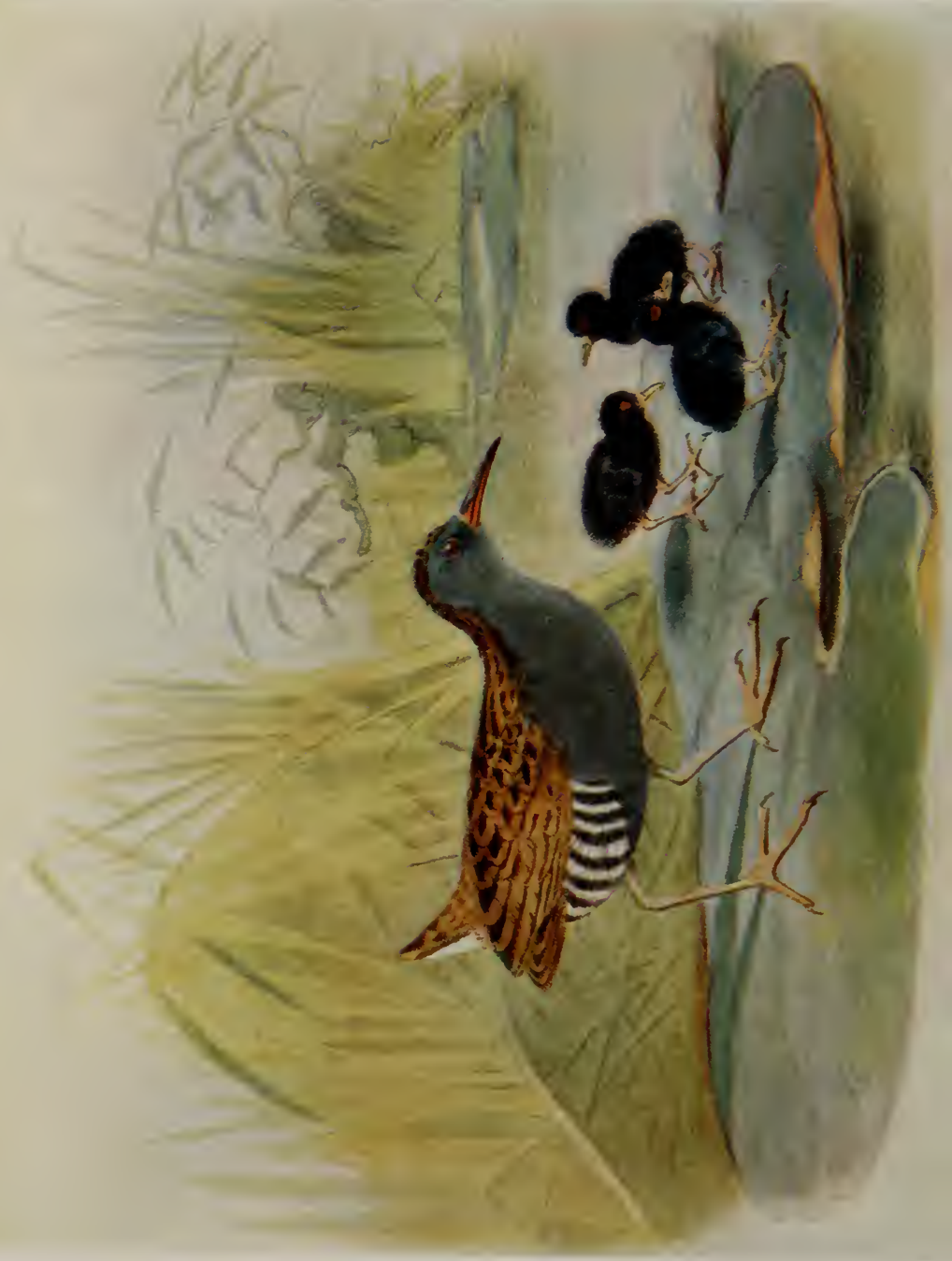





\section{The Little Crake}

from which it may be readily distinguished by the absence of spots on the throat or breast. Length 8 in.; wing $4 \cdot 2$ in.

\section{BAILLON'S CRAKE}

\section{Porzana bailloni (Vieillot)}

This species has only been met with in these islands on the spring and autumn migrations; on one or two occasions it has been recorded as having bred in the eastern counties, but although there is no great improbability about this, British-taken eggs have never been thoroughly authenticated. On the Continent it breeds freely in Western Europe, from Holland southwards as far east as North Italy.

In plumage it closely resembles the Little Crake, from which it may always be distinguished by having the outer web of the first primary white. Length 7 in.; wing $3 \cdot 45$ in.

\section{THE WATER-RAIL}

\section{Rallus aquaticus, Linnæus}

This species is tolerably abundant throughout Great Britain wherever swamps and sedge or reed-beds are sufficiently large to afford it cover. It is most abundant in winter, when our native birds receive large additions from the Continent, especially during severe weather.

During the breeding season it is very noisy, making a 287 


\section{Birds of Britain}

loud and peculiar noise, known in some localities as "sharming." Extremely loth to take wing, but swimming, and diving with great facility, it is very difficult to get a sight of this bird, except during severe weather, when the cover is more scanty, and lack of food compels it to leave its usual haunts. The nest is placed in a thick tuft of sedge or reeds and is a deep cup-shaped structure of flags; the eggs are pale creamy white, flecked with a few reddish spots, and are seven to nine in number. The food consists of worms, snails, and other aquatic insects and plants.

The adult has the back dark brown, with broad olive brown margins to the feathers; cheeks, neck, and breast lead grey; vent buff; flanks black, barred with white. Bill red. Length 11.5 in.; wing 4.75 in.

The young have the under parts dull brownish, barred on the flanks with dark brown. The female has occasionally some of the wing coverts black, barred with white, but this is a very variable feature. This species is subject to considerable differences in size and also in the intensity of colouring on the beak, breast, and under parts.

\section{THE MOOR-HEN}

\section{Gallinula chloropus (Linnæus)}

This is the commonest, tamest, and best known of the Rails, and occurs abundantly throughout the British Isles wherever some water surrounded by cover is found, even though it be a small ditch or pond. It has even penetrated 288 




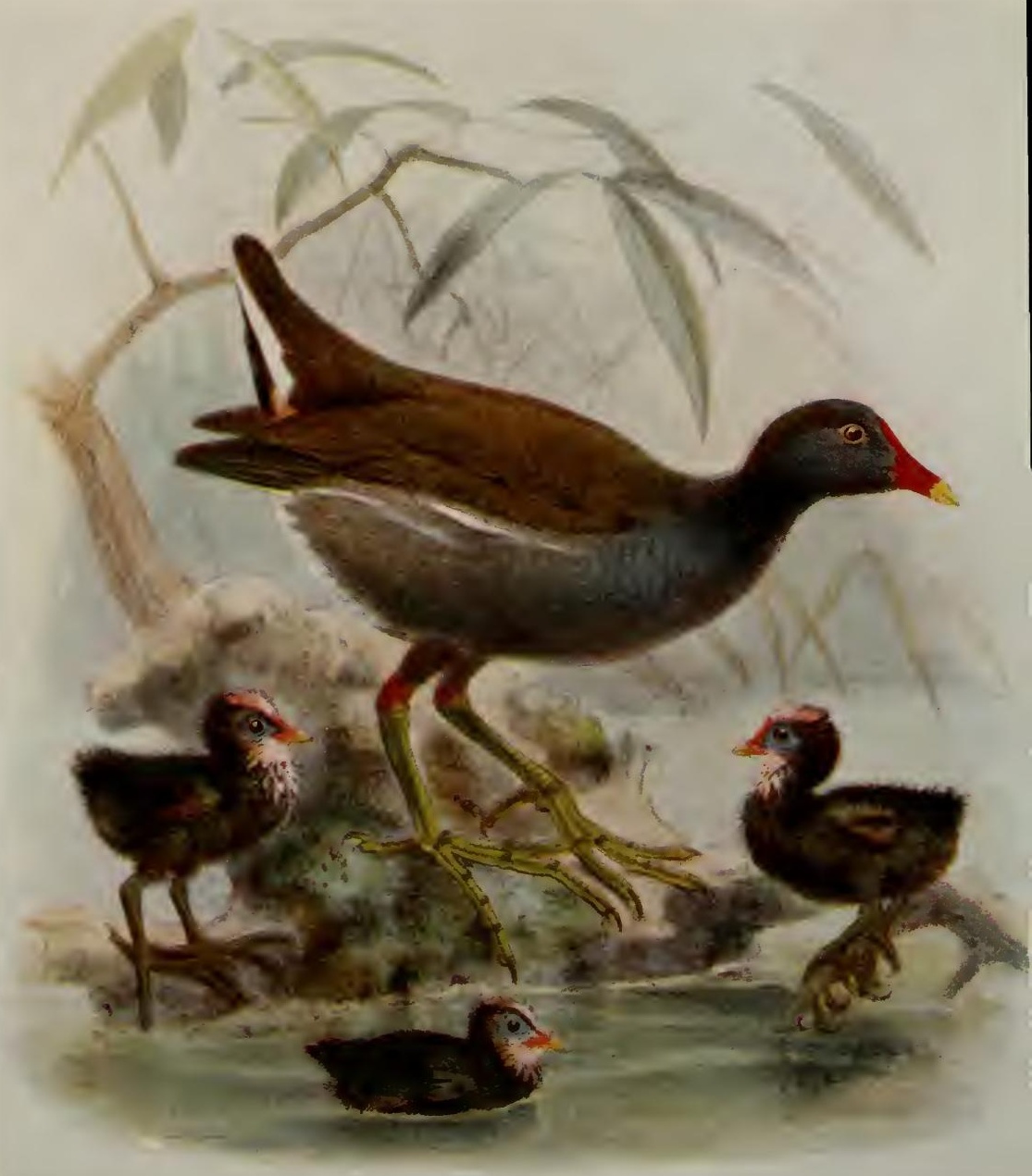





\section{The Moor-hen}

into the heart of London, and may be watched as it comes out to pick up the crumbs thrown by the passer-by, and takes them back to her young concealed in the rushes. Their food consists of insects, worms, slugs, aquatic vegetation, and a certain amount of grain. In some districts considerable damage is done in early spring to the watercress beds, the fresh tender shoots being nipped off as soon as they start to grow.

In April several nests are partially begun; these are generally situated in clumps of sedge or rushes, but are sometimes built under bushes, or even trees, at some height above the ground. In one of these partially-built structures the eggs will be laid, and as soon as the site has been definitely chosen a considerable amount of material is added, and the higher leaves of the sedge are often bent over so as to conceal it from above. The young when first hatched are black, with the base of the beak bright red like that of their parents, but after about a fortnight this colour is lost, the beak and frontal plate becoming brownish green. The first few weeks are spent entirely on the water or in the thick cover fringing the banks of a pond or stream, and at such times the half-completed nests are utilised as nurseries on which to brood the young. Both parents feed and tend the young, and on the approach of danger safety is sought by diving. When swimming the Moor-hen proceeds slowly, with a curious bobbing motion of the head and neck, and on land, when undisturbed, it walks slowly, raising its tail at every step and thus displaying the white under tail coverts; if alarmed, however, it lowers its head and runs with considerable rapidity and shows no white whatever. 


\section{Birds of Britain}

It remains on the ground all day and roosts at night among the sedges and rushes, but in frosty weather it invariably roosts on trees.

The sexes are much alike: the upper parts dark olive brown; head, neck, and under parts bluish grey; the flank feathers streaked with white, under tail coverts white. Bill bright red at the base, with yellow tip in summer; dull olive brown in autumn and early winter. Legs greenish yellow. The young have the chin white, under parts greyish brown; they are also greyer on the back than the adults. Length 13 in.; wing 6.75 in.

\section{THE COOT}

\section{Fulica atra, Linnæus}

The Coot is found on most of the open sheets of water throughout the country; it differs from its other congeners in being far less skulking and spending most of its time out on the open water, and procures much of its food by diving. Its feet are lobed, that is to say, have flat extensions of the skin which is constricted at the joints, down all the toes.

The nest is a huge structure of reeds and rushes placed well away from the shore, in a small clump of reeds, and the eggs, which number seven to ten, are very pale stone colour, minutely speckled and dotted with dark brown. The young bird when first hatched is black except for his head, which is sparsely covered with coarse down-like hairs of a red and orange tint.

Its food consists of aquatic insects and vegetation, as is 290 


\section{The Coot}

the case with the Moor-hen. In winter, although a resident, it collects in large flocks, and many visit the bays and estuaries round the coast, receiving considerable additions to their numbers from the Continent. The Coot is extremely wary and difficult to approach, taking wing on the least sign of danger; it flies well and fast, carrying its legs stretched out behind, but has to run along the surface of the water for some distance before it can rise. The sexes are alike and have the whole of the plumage sooty black, with a narrow white bar across the wing. Bill and frontal plate white; legs dark green. Length 15 in.; wing 8.5 in.

Although as a rule this bird casts its primaries at once, this is not invariably the case, as it sometimes moults them in pairs like the majority of birds.

\section{THE CRANE}

\section{Grus communis, Bechstein}

Three centuries or more ago the Crane bred regularly in our eastern counties, and for long afterwards it used to appear as a regular migrant every winter. At the present time, however, it is an extremely scarce and irregular visitor. It still breeds in Southern Scandinavia and thence southwards and eastwards throughout the whole of Europe. Its general colour is dark slaty grey, devoid of any markings. The inner secondaries are long and drooping and conceal the tail. The adults have a red warty patch on the crown. Length 45 in.; wing 21 in. 


\section{Birds of Britain}

\section{THE GREAT BUSTARD}

\section{Otis tarda, Linnæus}

In the early part of the sixteenth century the Great Bustard was well known and widely distributed throughout the moors and plains of England and the lowlands of Scotland. The increasing population, and cultivation of waste lands, gradually diminished localities suitable to its habits, and in 1838 the last eggs of our indigenous birds were taken.

At intervals irregular wanderers still occur in different parts of our islands, and several attempts to reintroduce this fine species in recent years have failed. In Spain, parts of Germany, and Southern Russia, this species is still to be found as a resident and breeding bird, but over the rest of Europe it is only known as an irregular visitor.

The male has the head bluish grey; rest of upper parts brownish buff, barred with black; wing coverts white; quills blackish. Breast banded with chestnut and grey; belly white. Length 43 in.; wing 24 in.

The female is smaller and lacks the band on the breast.

\section{THE LITTLE BUSTARD}

Otis tetrax, Linnæus

The Little Bustard is ouly a scarce visitor, and has most frequently occurred on our southern and eastern coasts. It 


\section{The Little Bustard}

is a south European species, but breeds regularly on the plains of France, where it arrives in April and leaves in September.

The general colour of both sexes is sandy brown, streaked and vermiculated with black on the upper parts; the under parts are chiefly white. In summer the male has the throat and upper breast black, shading to grey on the chin, and crossed with irregular white bars. Length 17 in.; wing $9 \cdot 5$ in.

\section{MACQUEEN'S BUSTARD}

\section{Otis macqueeni, J. E. Gray}

This is an Eastern species, breeding from Asia Minor eastwards towards the Caspian and Aral Seas, and has only occurred on two or three occasions in these islands.

This species may be recognised by having a crest of white feathers tipped with black, and a blackish ruff on the sides of the neck. The rest of the plumage above is buff, vermiculated with black, and the under parts are white. Length 38 in.; wing 15.5 in.

\section{THE STONE-CURLEW}

\section{Edicnemus scolopax (S. G. Gmelin)}

The Stone-Curlew is a summer visitor to this country, frequenting wild, sandy " brecks," and undulating chalky downs. 


\section{Birds of Britain}

It is therefore a somewhat local species, being commonest perhaps in the "breck" district of Norfolk and Suffolk; it is also found on the downs of most of the southern and eastern counties, as well as on the Chilterns and in one or two other counties to the north, but in the west of England, Scotland, and Ireland it is entirely absent, and has only occurred on very few occasions.

Sandy brown in colour, it assimilates so well with its surroundings that it is very difficult to see, and when approached will often "squat," stretching its neck out to its fullest extent, and so escape observation. It runs with great rapidity and flies strongly, its flight rather resembling that of a Pigeon, while the white bars on the wing coverts show up conspicuously. Its food, which is chiefly taken at dusk and dawn, consists of insects of all kinds, especially beetles.

Living as it frequently does in districts away from water, it journeys nightly to a favourite watering-place. The note is a loud whistling cry, which is uttered at night, and during the early spring these birds are very noisy.

The two eggs are deposited towards the end of April or beginning of May on the bare ground, a spot where there are many loose stones, among which they are very difficult to see, being usually chosen. In colour the eggs are pale clay spotted and streaked with dark brown, those in the same clutch being often very dissimilar in markings. Both sexes assist in the duties of incubation and rearing of the young, who, when first hatched, are pale buff with a longitudinal dark line down each side of the back. Their legs are much thickened, a feature common to many Limicoline birds, and this has led to this species being sometimes known 

STONE CURLEW

Edicnemus scolopax. 


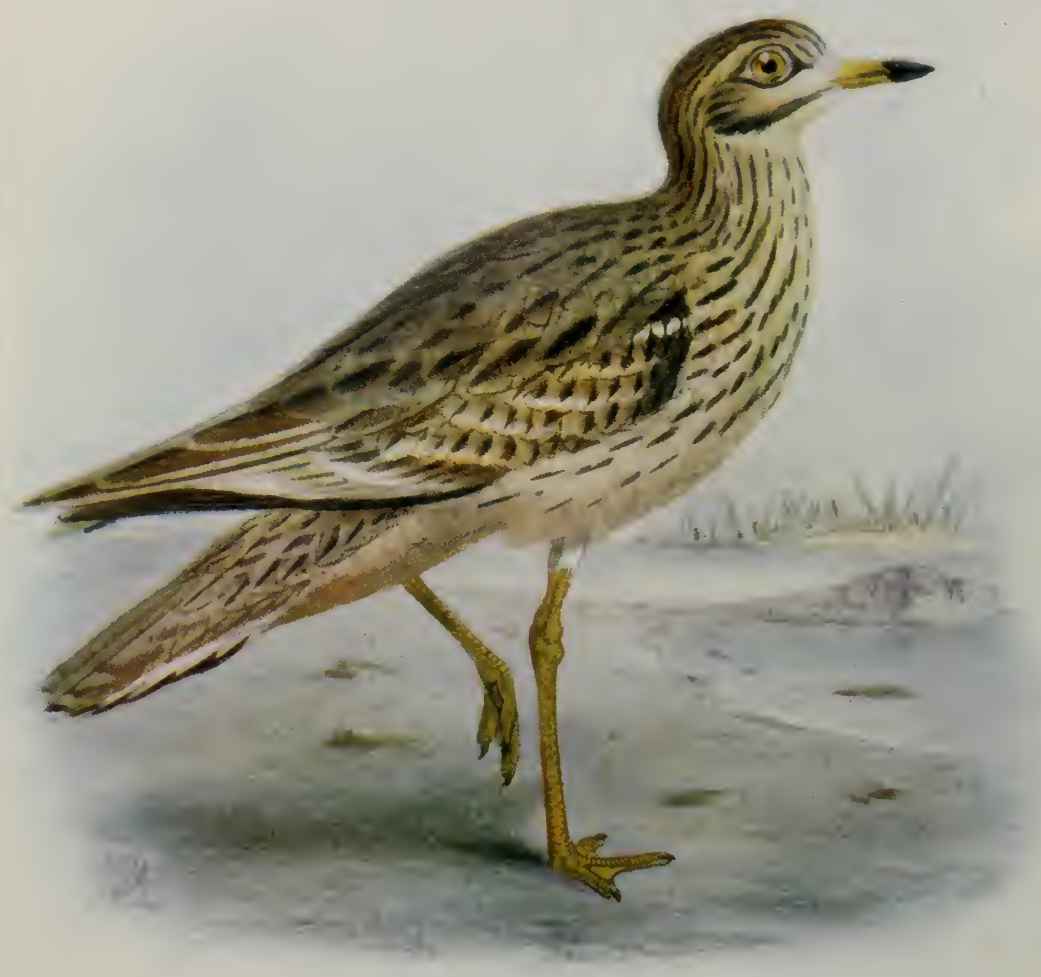





\section{The Stone-Curlew}

as the "Thick-Knee." In August old and young gather together in flocks and shortly afterwards take their departure, though occasionally individuals have been known to pass the winter in this country.

The sexes are alike in plumage. The upper parts are of a uniform sandy brown, with dark streaks down the centres of the feathers; some of the wing coverts tipped with white to form two narrow bars. Neck and breast pale brown streaked with darker. Throat and belly white. There is also a white stripe under each eye. Bill yellow with a black tip; legs greenish yellow. Length 16 in.; wing $9 \cdot 25$ in.

The young are similar to their parents but browner, and the tail feathers are more barred.

\section{THE PRATINCOLE}

\section{Glareola pratincola (Linnæus)}

The Pratincole is a native of Northern Africa, Asia Minor, and Palestine, but it also nests in certain suitable districts in South Europe, where it is only known as a summer visitor. In England it has not infrequently been taken on both spring and autumn migrations.

The adult has the upper parts clove brown. Tips of secondaries, tail coverts, and bases of tail feathers white. Under wing coverts chestnut. Throat buff, margined with black; breast brownish, turning to white on the belly. Length 10.5 in.; wing 7.5 in. 


\section{Birds of Britain}

\section{THE BLACK-WINGED PRATINCOLE Glareola melanoptera (Nordmann)}

This is the Eastern form of the above, nesting from the shores of the Black Sea eastwards to the Altai. Two specimens, which came over in company with the commoner species, were shot in Kent in June 1903.

It may be recognised by the under wing coverts being black and the absence of the white tips to the secondaries.

\section{THE CREAM-COLOURED COURSER}

\section{Cursorius gallicus (J. F. Gmelin)}

Inhabiting dry and arid regions south of the Mediterranean, this species has nevertheless wandered up to our islands on several occasions, and curiously enough always on the autumn migration, between October and December. The general colour above and below is sandy buff; quills and under wing coverts blackish. There is a dark stripe behind the eye, and the nape is bluish black, this colour extending forward to the eye. Length $10 \mathrm{in}$.; wing $6.3 \mathrm{in}$.

\section{THE DOTTEREL}

\section{Eudromias morinellus (Linnæus)}

A lonely, bleak and bare wind-swept moorland, where the scanty herbage is kept short by the elements and the 296 


\section{The Dotterel}

wandering flocks of mountain sheep; and where the sounds of nature are supplied on most days by the wind as it rushes down the valleys between the rounded hill-tops, to the accompaniment perhaps of the Curlew's wild whistle, or where on the few calm days in summer a deathly silence prevails, broken only by the humming of a bee as it visits the purple heather, or the clear "go back, go back" of the male Grouse. In such a spot one may hear a low monotonous whistle, or have one's attention attracted by a small flock of rapidly flying birds skirting the crest of the hill; these are Dotterel, and this is their summer home. This bird is extremely, one might almost say foolishly, tame, though often owing to this tameness it will escape observation, for, instead of taking wing as we approach, it will either stand motionless, or running to the far side of some patch of heather remain unseen, as its colours harmonise so well with the surrounding heather.

The nest is a mere scrape in a bare spot, and hardly any materials are brought together, though a few bits of moss and lichen may be arranged round the eggs. These are three in number and are greenish in colour, very boldly blotched and marked with brown. Both sexes perform the duties of incubation and attend to the wants of the young when hatched.

In this country this species is only a migrant, and in September leaves the hill-tops, and passing through the lower lying counties of England wings its way to other climes.

The sexes are alike and are sandy brown on the back, with longitudinal fulvous markings; there is a white stripe 


\section{Birds of Britain}

over the eye. Chin white; breast ash brown, bordered with a narrow white transverse band; lower breast chestnut; belly black. In winter the under parts are pale ash brown. The young have rufous edgings to the feathers of the back, but otherwise resemble their parents in winter dress. Length 9 in.; wing 6 in.

\section{THE CASPIAN PLOVER}

\section{Egialitis asiatica (Pallas)}

Two examples of this eastern Plover, which inhabits the Caspian and Aral Sea region, were obtained near Yarmouth in May 1890.

It is not unlike our Common Ringed Plover, but lacks all the black markings on the head, and the band across the breast is bright chestnut, edged along its posterior margin with black. Length 7.5 in.; wing 5.6 in.

\section{RINGED PLOVER}

AEgialitis hiaticola (Linnæus)

Few people can have walked along our shores without having their attention attracted by the plaintive whistle of this delightful little bird. It will suddenly be seen flying past, the dark ring showing up in contrast to its white breast, while as it gets farther away a light line across the out298 


\section{Ringed Plover}

spread wing will also help to distinguish it. When it settles, especially if among stones and shingle, we shall have hard work to see it, while the oft-repeated note, sounding first on one side and then on the other, and coming apparently from the dark stones themselves, tends to bewilder us. There is no month in the year when we cannot find this bird on our shores whatever be the weather-amidst a howling winter's gale and driving sleet, or under the blazing summer's sun, when we can see the heated air vibrating over the burning stones, he is still there, apparently absolutely unmoved by the all-powerful forces of nature. But the time to see him at his best is in May; we are walking along when suddenly his well-known note strikes our ears, and we see him running along in front of us; we sit down to watch him and he in his turn will suddenly stop, and then running to some stone slightly higher than its neighbours, stand up and watch us. His mate soon joins him and together they stand, now running a few yards and then turning round give us another look, while they bob their heads up and down at the same time with a motion so characteristic of the Plovers. Finally, seeing that we do not go away they both get up and, calling out as they do so, fly off; but in a minute or so one of them is back again, sitting and watching us from his old stand. They have evidently a nest somewhere near, and equally, evidently, the hen has evaded our vigilance and is closely sitting on her treasures. Disappointed we rise to go, and on our doing so the hen rises apparently from the ground within six feet of us and runs away.

One step, and there on the bare stones are four pearshaped eggs lying close packed, with their narrow ends to 


\section{Birds of Britain}

the centre, and practically indistinguishable from the shingle on which they lie. In colour they are pale clay, uniformly covered with black spots and mottlings. As soon as the birds see that their treasure is discovered they fly round us, calling out continually till we pass on, leaving the hen to resume her duties. The young are covered with thick down when hatched, and are brown, mottled with black on the back; below white, with a black ring round the chest. They leave the nest as soon as they are hatched, and very shortly begin to feed themselves on the various spiders, flies, and other small insects that abound in such places. Both parents carefully watch and tend them, flying up on the approach of danger, while the young squat closely on the ground, where they become almost invisible. Their wings grow when at the age of five weeks, by which time they are nearly as large as their parents, and are then well able to take care of themselves and wander away to join the flocks of their own kind, or to amalgamate with other passing wanderers, and add their cries to swell the sounds of the shore, which are such a delight to every naturalist.

The sexes are alike in plumage. General colour above pale sandy brown; below white. Forehead white, succeeded by a black band; lores and band across chest black. Legs bright yellow; beak black, yellow at its base.

The young resemble the adults, but lack the black band on the forehead; the chest band is brown concolorous with the upper parts. The legs olive green.

Generally distributed along the shore and in some inland sandy places throughout the British Isles. 

RINGED PLOVER

Egialitis hiaticola

Male (right). Young (left) 


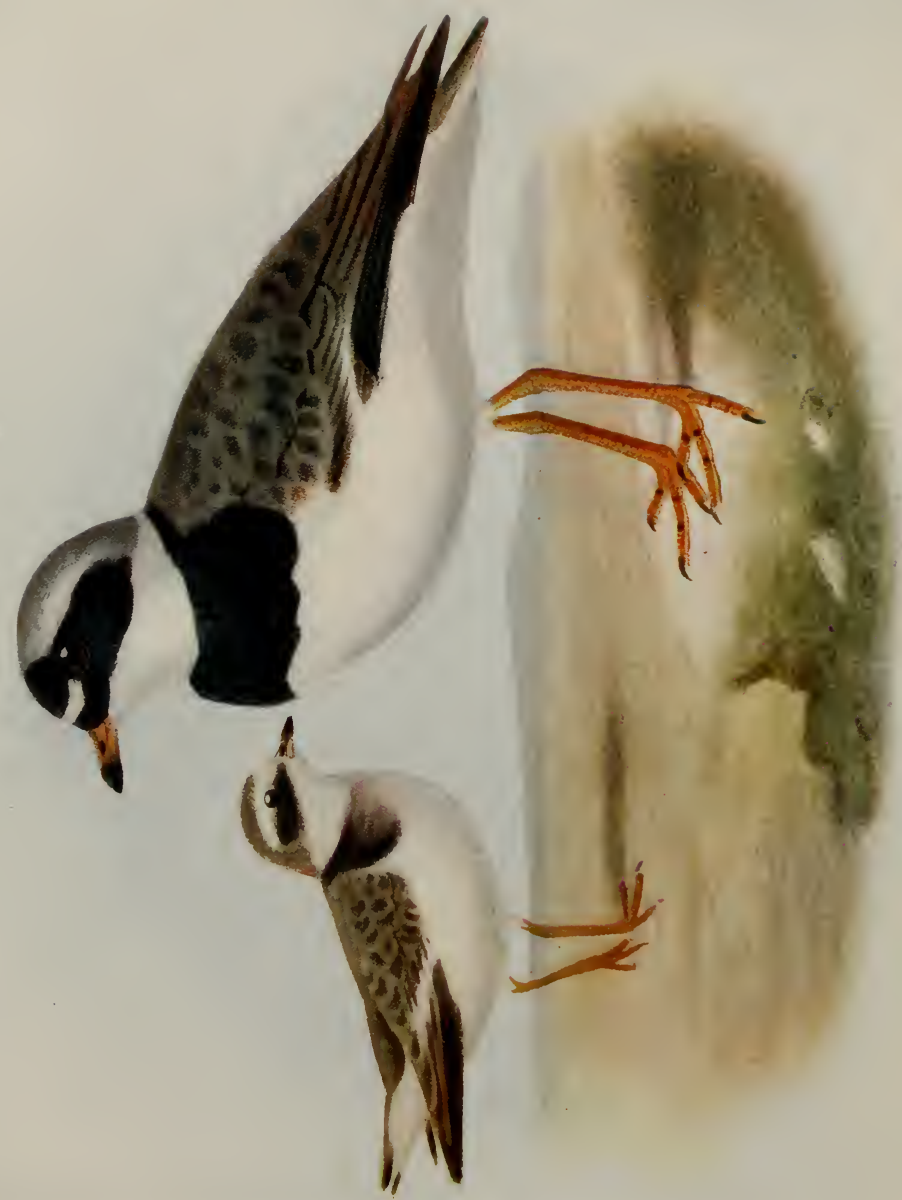





\section{The Little Ringed Plover}

\section{THE LITTLE RINGED PLOVER}

Egialitis curonica (J. F. Gmelin)

This species breeds in Scandinavia and throughout Europe, being rather scarcer in the west. To our shores it is only a very occasional straggler, not more than half-adozen authenticated instances being known.

It resembles the preceding species, but is rather smaller in size, paler in colour, and the bill is narrower, longer in proportion, and wholly black. The best characteristic, however, is that the shafts of all the primaries, except the outer ones, are dusky, whereas in the Ringed Plover they are all flecked with white to form a conspicuous bar when the wing is opened. Length $6.5 \mathrm{in}$; wing $4.5 \mathrm{in}$.

\section{THE KENTISH PLOVER}

\section{Egialitis cantiana (Latham)}

As the Ringed Plover is one of our commonest shore birds, so the present species is one of our rarest, and it will never be met with unless a special journey is made to that lonely stretch of shore, which is its only home in these islands. In habits it is almost the counterpart of the Ringed Plover, but is a true migrant, arriving in April and leaving in September. The note is a short monosyllabic whistle and quite distinct from that of the preceding species. 


\section{Birds of Britain}

It is a smaller bird than the Ringed Plover, which it otherwise resembles, except that the dark band across the chest is broken in the centre. Female and young resemble the male, but the band on forehead and chest is brown instead of black, and of the same colour as the upper parts. Length 6.25 in.; wing 4.25 in.

\section{THE KILLDEER PLOVER}

\section{Agialitis vocifera (Linnæus)}

Only two examples of this American species have been shot in England. It is a larger bird than any of our other Ringed Plovers, which it somewhat resembles, but it may be recognised by its rufous rump and upper tail coverts, a black subterminal bar and white tip to all the tail feathers except the central pair, and the presence of two narrow black bands across the breast. Length 9.5 in.; wing 6.5 in.

\section{GOLDEN PLOVER}

\section{Charadrius pluvialis, Linnæus}

The home of the Golden Plover is on the lower slopes of those hills the tops of which the Dotterel takes as his own, for the Golden Plover prefers the cover afforded by the tall heather and the more abundant and varied insect diet of the lower lands. 


\section{Golden Plover}

As we walk up the hill we first hear his shrill whistle, and soon see him coming to meet us. Settling some yards ahead, he pipes his whistle incessantly, and then as we approach he flies on to some other upstanding boulder, and so on for perhaps half-a-mile, till, having escorted us to the limits of the ground over which he claims suzerain rights, he hands us over to the ruling chief of the next territory. Thus in a walk over the hillside we find ourselves incessantly accompanied by one of these birds, whose cry is never out of our ears. We have, however, only noticed half the game, for the birds that have been accompanying us are almost always male birds: his duty it is to stand on some exposed mound while his hen crouches amid the heather on her precious eggs, four pear-shaped beauties, the black spots and markings showing up against their greenish ground colour. On the first appearance of any intruder he will sound his pipe and fly off towards us, while his mate quietly leaves her eggs, and, flying low, circles round till we see her apparently coming up from a direction diametrically opposed to that in which her treasures lie. It will be unavailing for us to lie in wait hoping to watch her return to the nest, unless we are completely concealed, for he will keep a close eye upon us, and until his warning whistle is quiet she will not return. When the young are hatched both birds meet and follow us, while in response to the warning, the young squat close to the ground, under some sheltering piece of heather, and so defy detection. In autumn these birds collect in large flocks, and though many remain on the moors all the year round, the majority come to the marshes near the sea and gradually pass southwards. 


\section{Birds of Britain}

The sexes are alike in plumage. The whole of the upper parts are dark brown, with two or more yellow spots on the margins of each feather. The throat and breast are black, bordered by a clear-cut white line. Bill and legs black. In winter the black on the throat and chest is replaced by white, with pale brownish mottlings across the latter. Length 11 in.; wing 7.5 in.

The young resemble their parents in winter but the yellow is brighter, and there are traces of yellow across the breast. It is generally distributed throughout these islands, breeding commonly on the moorlands, and becoming much more numerous in Scotland.

\section{THE LESSER GOLDEN PLOVER}

\section{Charadrius dominicus, P. L. S. Muiller}

This species is subdivided into two forms, one of which is found in Eastern Asia, while the other is an inhabitant of North America.

Examples of both these forms have been shot in the United Kingdom, although the American form, as might be expected, has occurred the more frequently of the two.

Both these forms may be distinguished from our common species, which they closely resemble, in having the axillaries smoke grey instead of white. Length about 9 in.; wing 6.75 in. 

GOLDEN PLOVER

Charadrius pluzialis

(left)

GREY PLOVER

Squatarola helvetica

(right) 


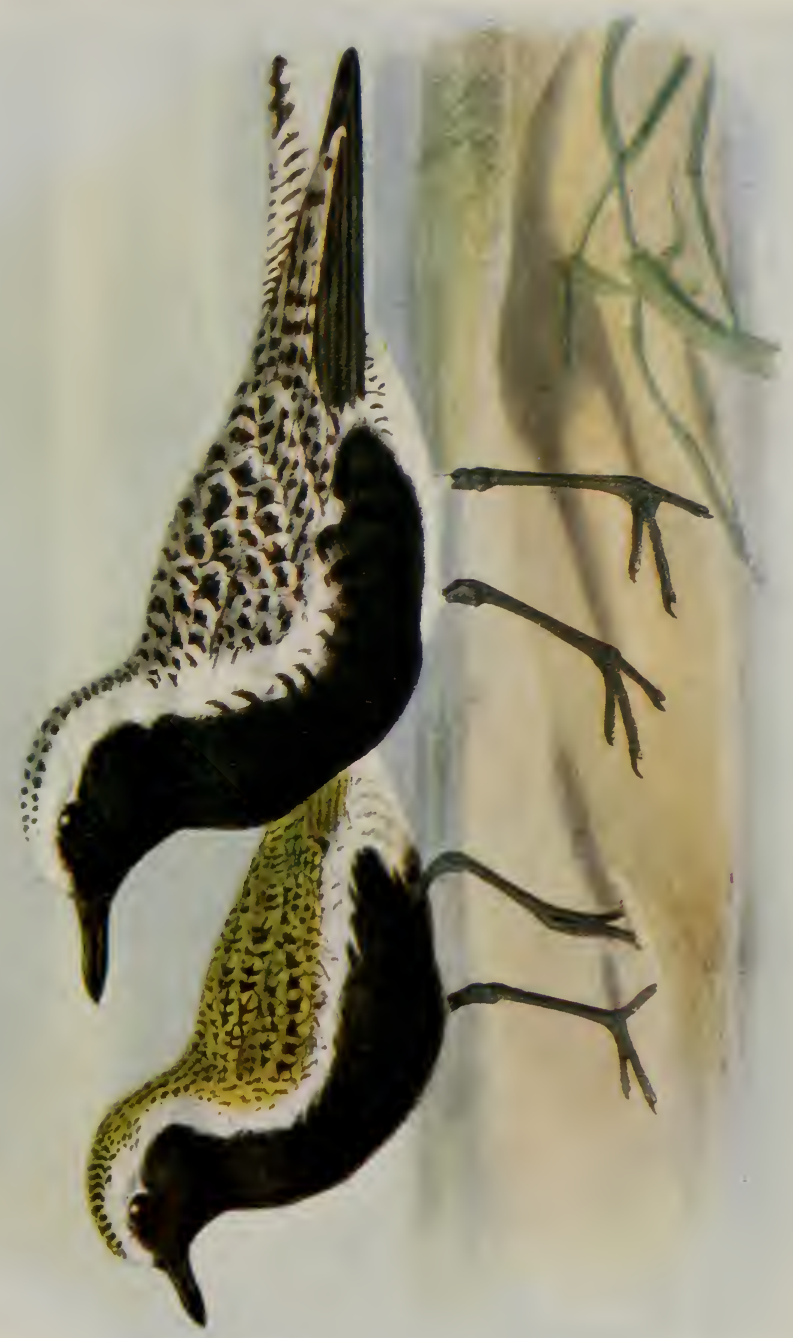





\section{Grey Plover}

\section{GREY PLOVER}

\section{Squatarola helvetica (Linnæus)}

Very similar to the Golden Plover in general appearance, but the yellow spots are replaced by whitish, and the hind toe is lacking. A few weeks in spring and autumn along the shore is all the time this bird spends with us; he passes the winter in the warm tropics of Africa, wandering southwards as far as the Cape, and then, obeying some mysterious impulse of which we can form no conception, he journeys in May northwards, and passing over many spots, which would to our ignorant eyes afford him food and shelter sufficient for the rearing of his young, he seeks out the wild and lonely tundras of Europe and Siberia.

There during the eternal day of an Arctic summer he rears his family, and as soon as they can fly, old and young are back again on our shores. For some weeks they remain, slowly passing to the south, and, unlike the Golden Plover, rarely coming inland; but by the middle of October they are all back enjoying once more the burning sun of the tropics.

The white tail coverts and absence of the hind toe will prevent any confusion between this species and the Golden Plover. Length 11.5 in.; wing 7.75 in. 


\section{Birds of Britain}

\section{THE SOCIABLE PLOVER}

\section{Vanellus gregarius (Pallas)}

This species is a native of South Russia and the AraloCaspian area. Until a few months ago, when a second example was procured in Kent, it had only once (in 1860) been taken in England.

The general colour above is drab; crown of the head black, margined with white. Quills black; secondaries white; tail white, with a subterminal brown band. Chin white; throat buff; breast brown; belly black; flanks and under tail coverts deep chestnut. Length 12 in.; wing 8 in.

\section{THE LAPWING}

\section{Vanellus vulgaris, Bechstein}

No wild bird has perhaps to pay so large a tribute in eggs and individuals to man, and yet remains as common and abundant, as the Lapwing.

Early in March he appears on the marsh or watermeadows, where he or his parents before him have been accustomed to spend the summer; sometimes dry fields at some distance from the water are chosen, but as a rule it is never far from a river, stream, or even a moderate-sized pond. Although many pairs often nest in the same field, fierce battles take place between the males for the mates of 306 


\section{The Lapwing}

their choice, but there is more "show" than strife, lengthy aerial chases with much calling out but very little serious fighting. Once, however, these early difficulties have been overcome, the colony settles down in peace, a few ousted pairs being left to seek some fresh ground.

The nest is merely a shallow platform of roots and bents, placed on a small hollowed-out "scrape" on the ground. Over the actual choice of a site there seems to be some difficulty, as many "scrapes" are generally to be found within a few yards of the spot eventually chosen. Towards the latter end of March the four pear-shaped eggs, so well known in poulterers' shops, are laid, and the hen commences her incubation duties, which last about nineteen days. During this period her mate wanders about in the vicinity of the nest, keeping an ever-watchful eye for any intruder. As soon as we are seen approaching he is up in the air, flying round with a great noise and performing at the same time a curious tumble, but recovering himself before touching the ground; after two or three minutes of these antics however, he goes away, having apparently no further interest in us or the place. We may then walk about the field in vain so far as that pair is concerned, for they will not return to settle while we are there and the eggs are so protectively coloured that the chances of our seeing them, even if we walk right by them, are exceedingly remote. While we were watching the male bird perform his curious antics, the hen, warned by his cries, quietly slipped off the nest, and flying low skimmed the next hedge and so away, and he, having watched her safely into a neighbouring field, goes off to join her and leaves us to find the eggs if we can. 


\section{Birds of Britain}

If we retire, however, they will not be long gone; he will soon fly back, and having ascertained that the danger is over and uttered no warning cry, she will immediately follow, and settling near the nest, run to it and once more cover her eggs. When the young are hatched, however, matters are very different; both birds will then rise, and flying round our heads beseech us with piteous cries to leave their young alone.

These cries serve the purpose of making the young squat and hide, and their greyish green down with black mottlings so exactly assimilates in colour with the ground, that they are almost impossible to see. The young leave the nest as soon as they are hatched, and utter a feeble cry not unlike that of the adults; at first their parents feed them most carefully, picking up grubs, flies, spiders, or any other insect that comes their way, while the young run up and take it from their beaks, but in a few days they feed themselves, though still carefully watched and fed by their parents. When they are full grown, at about six weeks old, they collect in large flocks and wander over the country. In October and November enormous flocks come over from the Continent and settle often for three weeks or a month in a particular field, which is usually resorted to yearly by these birds. As winter comes on they wander about according to the weather, wherever they can find suitable food, but with the first warm days of February the return north begins, and March finds them back once more in their summer home.

The upper parts are of a beautiful metallic green, the crown of the head and crest being almost black. Quills 308 



\section{LAPIVING}

Vanellus vulgaris

Adult, summer (right). Young (left) 


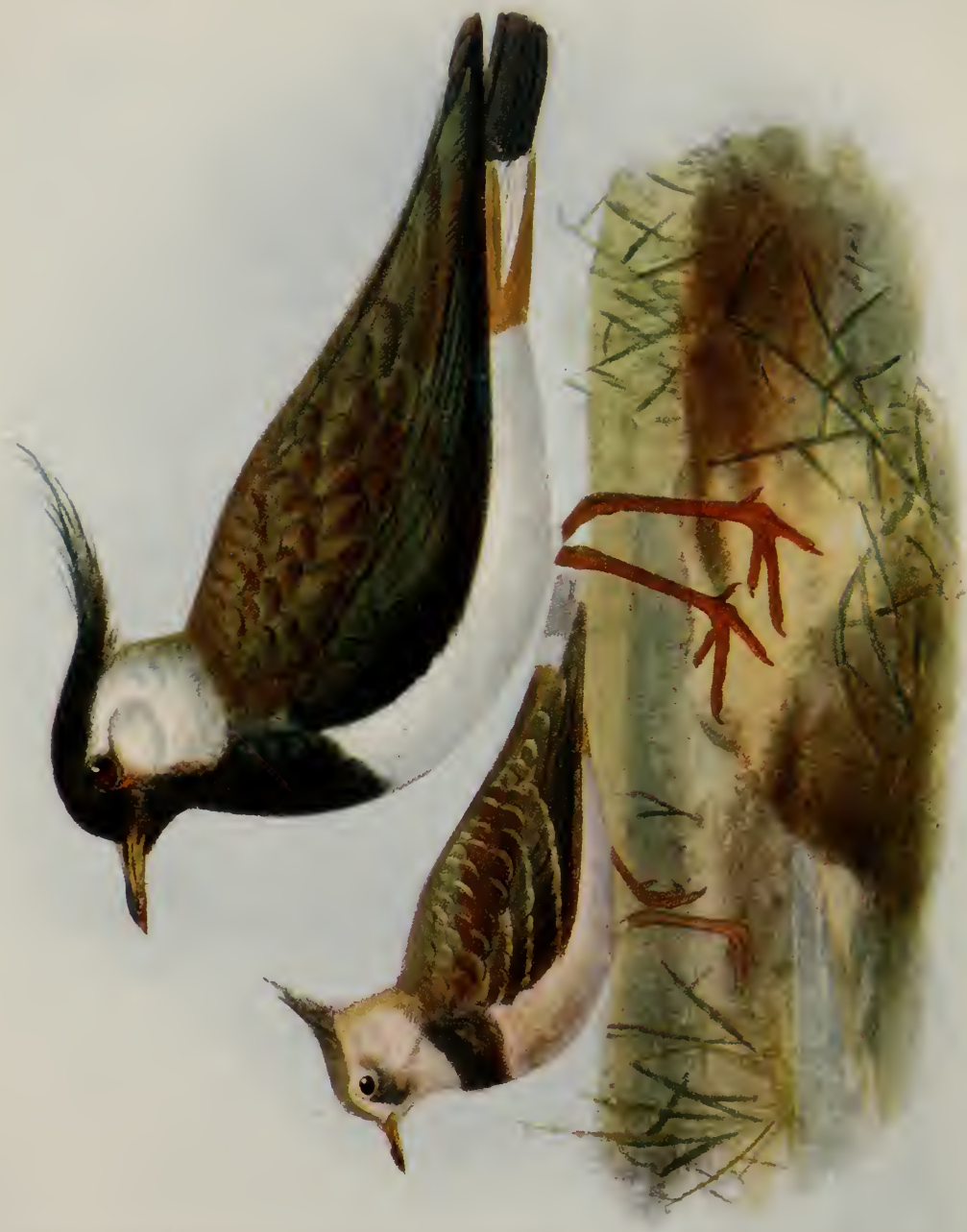





\section{The Lapwing}

black, tipped with grey on the three outer pairs; tail feathers white, with a broad subterminal band of black on all save the outer pair; breast black; under tail coverts chestnut; rest of under parts white. In summer the chin and throat are black. In the female the crest is rather shorter and the outline of the extended wing is straighter. Length 12.5 in. ; wing 8.75 in.

The young bird has buff margins to the feathers of the upper parts.

\section{THE TURNSTONE}

\section{Strepsilas interpres (Linnæus)}

Breeding in the Far North as well as on some islands in the Baltic, the Turnstone is only a migrant to our shores, spending some weeks with us in autumn and returning again on a flying visit on its way to its breeding-quarters. A small minority spend the whole winter with us, and occasionally birds in full nuptial dress have remained in one locality all through the summer, but its nest has never yet been found in these islands.

Although it may be met with along almost any part of the coast, it is most partial to rocky places and spots where shingle banks are found amongst patches of mud. Its food consists of insects and crustacea of all kinds, and its name is derived from the habit of turning over stones for the sake of the insects that are thus exposed.

The nest is generally placed on the sea-shore close to high-water mark, little rocky islets just off the shore being 


\section{Birds of Britain}

very favourite localities. The eggs are four in number and very characteristic of this species, being greenish grey in ground colour, spirally streaked with brown. It is a late breeder, rarely having eggs before the beginning of June.

After the nesting season it at once moves southwards, young being met with on our shores by the middle of August. At this time of year it collects in small parties of from twenty to forty, and where not disturbed they are fairly tame and allow their curious method of feeding to be easily observed.

This bird is very variable in plumage when adult: the head and neck are variegated with black and white; mantle variegated with chestnut and black. Rump and under parts white. Tail brown; breast and shoulders chiefly black. The female resembles the male, but is slightly larger. Most of the chestnut colouring is lost in winter. The young have the upper parts brown, the feathers edged with white. Under parts white. Collar and a patch on each side of the breast dark brown. Length 9 in.; wing 6 in.

\section{THE OYSTER-CATCHER}

\section{Hæmatopus ostralegus, Linnæus}

No one who has been along the shore in winter can have failed to notice the large flocks of black-and-white birds-Sea Pies as they are often called-sitting on a sandspit and, like Canute of old, defying the tide. There they sit, till, when the water is just about to touch their feathers, 


\section{The Oyster-Catcher}

they all rise as though with one mind, and shrieking out their shrill call as they go, pass along to the next promontory which will afford them dry foothold for a few minutes longer. Such is the Oyster-Catcher and such his life, restless as the tide itself near which he lives. $\mathrm{He}$ is a common and abundant bird throughout the year on all our coasts, feeding more especially on mussels and limpets, which its powerful wedge-shaped bill enables it to detach from the rocks. Other food such as crustacea and marine insects are also eaten. Early in spring the large flocks begin to break up into pairs.

As a rule the nest is on the shingle or the top of a low rock just above high-water mark, but where the rocks are steep and precipitous it is placed on the top of the cliff, many feet above the sea-level. In Scotland they sometimes nest inland along the river banks. The nest is merely a slight depression round which a few suails' shells or stones are laid, and it is to this habit rather than from its food that it owes the name of Oyster-Catcher. The eggs, two or three in number, are pale clay, freckled and spotted with black. Incubation is carried on by the hen, while her mate stands on some point of vantage from where, on the approach of a stranger, he gives vent to his loud and noisy "keep, keep, keep," which is continued until the supposed danger is past. On the first note of alarm the hen leaves her nest and soon joins in the chorus with her mate.

The young when first hatched are dark greyish brown, mottled and striped with black; they are at once taken to the shore and are very carefully watched over by their parents, who, when the tide is out, take them a considerable distance 


\section{Birds of Britain}

below high-water mark. One brood only is reared in the season, and as soon as the young can fly they begin to gather again into flocks.

The head and neck, scapulars and mantle, lesser wing coverts and tip of the tail are black, the rest of the plumage white. Bill orange vermilion; legs pink. The sexes are alike, and in winter there is a white crescent round the top and front of the neck, and the bill is horn-coloured at the tip. The bill is continually growing and so counteracting the wear and tear to which it is subjected. Length 16 in.; wing $9 \cdot 75$ in.

\section{THE AVOCET}

\section{Recurvirostra avocetta, Linnæus}

If only the amasser of British killed specimens could be exterminated and the protection laws of this country more rigidly enforced, the Arocet might once more become a local breeding species in some of our counties. At present, howerer, a few birds arrive in our southern and eastern counties yearly, and it is to be feared that but few live to cross over to their breeding grounds in Holland. It used formerly to breed in considerable numbers in the marshes of Kent and Sussex, and along our flat eastern shores, but on the west and in the north it has never been more than an extremely rare and local visitor. The nest is placed on the mud or sand in an estuary, and at no great distance from the water, and consists merely of a very small collection of dry bents and grass. The eggs are three to four in number and pale clay 

OYSTER-CATCHER

Hamatopus ostralegus

Summer 


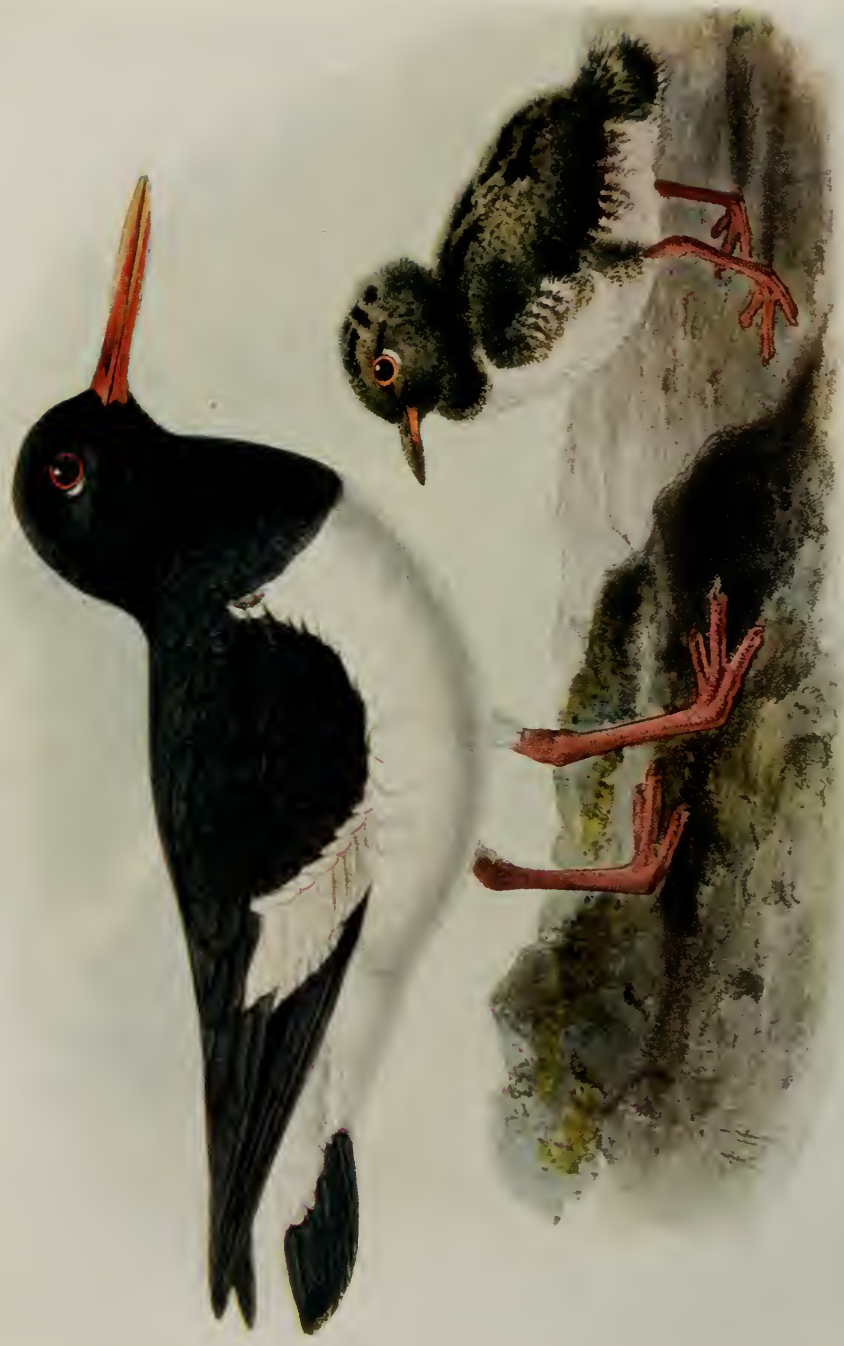





\section{The Avocet}

in colour, speckled with black. The note is a clear "kluit," generally uttered on the wing, and when disturbed these birds are very noisy. Their food consists of small insects and crustacea, which are captured by a sideways motion of its curiously shaped bill. It almost always feeds in shallow water, and when feeding walks along, slowly moving the bill from side to side on the surface of the mud. It usually flies high, and from its coloration and long neck is not unlike a Sheld-Duck when at a distance, but its clear and loud "kluit, kluit," soon betrays its identity.

The sexes are alike; the head and back of the neck, scapulars, median and tertiary wing coverts and some of the primaries black. Rest of the plumage white. Bill black; legs pale blue. In the young the black portions are brownish. Length 10 in.; bill $3 \cdot 2$ in.; wing $8 \cdot 5$ in.

\section{THE BLACK-WINGED STILT}

\section{Himantopus candidus, Bonnaterre}

This species is only a very scarce straggler to our shores, generally during the summer months. Its chief breeding grounds are along the shores of the Danube and Black Sea, and in the marismas of Southern Spain, whence it migrates to Africa in winter.

In the adult the mantle and wings are greenish black; tail grey; the rest of the plumage white. Bill black, and the long legs rose pink. Length 13.6 in.; bill 2.5 in.; wing $9.5 \mathrm{in}$; legs $10 \mathrm{in.}$ 


\section{Birds of Britain}

\section{GREY PHALAROPE}

Phalaropus fulicarius (Linnæus)

This species only appears as an irregular autumnal visitor on our south-eastern and southern shores, though it has been obtained both in Scotland and Ireland. In food and habits it resembles the Red-necked Phalarope, but its breeding range is more northerly, and is in fact circumpolar. It is extremely tame, and allows a close approach as it swims in shallow sheltered places a few feet from the margin of the shore, beach pools, or inland ponds, where it happens to be.

Its visits to this country are almost always in autumn, when it is in the grey plumage, which is grey on the back and white beneath, with a white forehead and a black streak running backwards through the eye. Bill black. The sexes are alike and the young similar but buffish on the chest.

A few solitary examples are sometimes seen in nuptial dress during the spring or very early autumn. In this plumage the head and back are black, with rufous margins to the feathers; cheeks white; under parts chestnut. Bill yellow. The male is rather duller in plumage than the female. Length $8 \cdot 25$ in.; wing 4.9 in. 

GREY PHALAROPE

Phalaropus fulicarius

(left)

RED-NECKED PHALAROPE

Phalaropus hyperboreus

(right)

Both in winter 


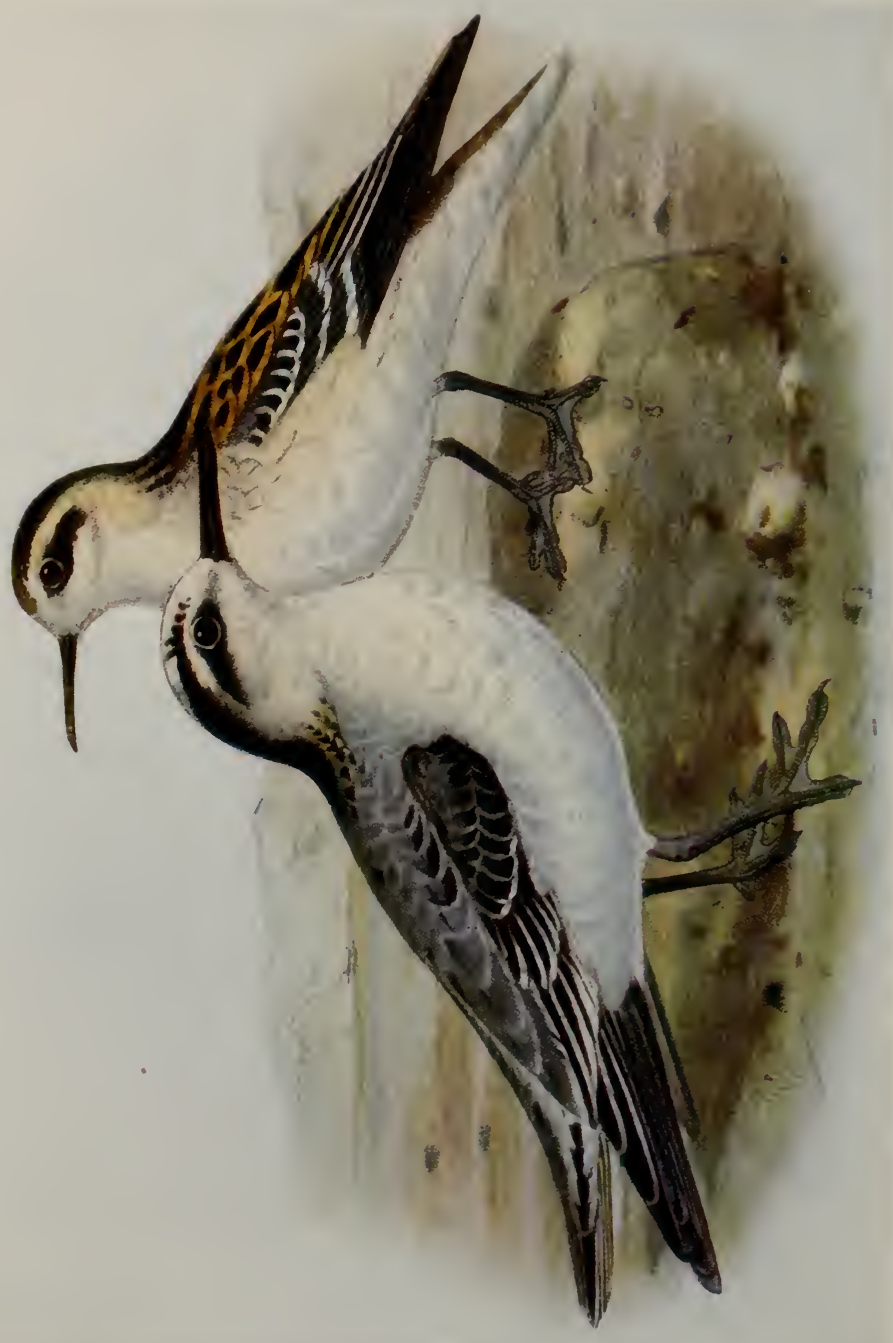





\section{The Red-Necked Phalarope}

\section{THE RED-NECKED PHALAROPE}

Phalaropus hyperboreus (Linnæus)

The Phalaropes are delightful little birds of very aquatic habits, and form a splendid instance of how similar environment tends to the production of similar structure. They may be easily recognised from other limicoline or wading birds by their very close feathering, especially on the breast, and their lobed feet, while in the Grey Phalarope, especially, the bill is somewhat flattened, so that in these birds we find a tendency towards the flattened bill as in Ducks, lobed feet as in the Grebes, and the peculiar thick feathers on the breast characteristic of Petrels and Gulls. The Phalaropes have also another peculiarity unique among British birds, although shared by several other groups in different parts of the world, namely that the duties of incubation and rearing of the young are conducted entirely by the male bird, and in correlation with this habit the female does all the courting and is brighter in plumage.

One or two spots in Scotland and Ireland are the only remaining places in our islands where this delightful bird may be found nesting, and as an antumn and winter visitor it is decidedly rarer than the preceding species, and very seldom found inland during the winter months. When visiting us it will usually be seen swimming in some sheltered tidal pool or in one of the ditches of the marsh, close to the sea-wall. Its food consists of small insects 


\section{Birds of Britain}

and crustacea. At its breeding haunts it is extremely tame, running about within a few feet of the intruder.

Its summer home is usually on some inland bog, and the nest is placed on a small tussock in a very wet place, often entirely surrounded by water. The eggs are four in number, very pyriform in shape, and large for the size of the bird, but owing to the nest being a deep cup, the surface of the eggs that has to be actually covered by the bird is comparatively small.

In colour they are pale olive very thickly spotted and streaked with black. The male undertakes all the duties connected with the young, the female taking no notice of the nest after the laying of the last egg. Frequently the female at the beginning of the breeding season is accompanied by more than one male, so that it is probable that polyandry exists in this group, as it has already been proved to do in other cases where the courting is undertaken by the female.

The call-note is a low "wit, wit, wit." In summer the head, neck, and shoulders are lead grey, the back and wings darker, with a mixture of pale rufous. A bar across the wings white. Sides and front of the neck chestnut; breast lead grey; chin and rest of under parts white. The male is rather duller than the female. In winter the forehead, crown, and under parts are white, feathers of the back grey, with white margins. The young have rufous margins to the feathers of the back, but otherwise resemble their parents in winter dress. Length $7.5 \mathrm{in}$; wing $4.4 \mathrm{in.}$ 


\section{The Woodcock}

\section{THE WOODCOCK}

\section{Scolopax rusticula, Linnæus}

The Woodcock is best known in these islands from the vast numbers that annually arrive during October to pass the winter with us. Although fairly well distributed at this time of year, they are most abundant in Ireland and our western counties, where they form one of the chief objectives of the shooter.

As its name indicates, the Woodcock spends most of its time in woods and plantations, flying every evening to wet meadows and marshes in the neighbourhood, where it feeds on worms and other insects, and returning to the woods before daybreak. On its passage to and from its feeding ground it always follows certain tracks, which are in consequence often known as "cock-roads." Early in March the vast majority take their departure for their breeding grounds in Northern Europe, but some remain to nest with us, and of late years its numbers as a breeding species have considerably increased.

The nest is a slight depression among dead leaves, generally at the foot of a tree. The eggs are four in number and yellowish white in colour, blotched with ash grey and reddish brown. When the young are hatched they are sometimes removed by the parents, the female being said to carry them by holding them pressed closely to her body between her legs. In common with all Snipe, the eye is placed far back on the head, and it has recently been 


\section{Birds of Britain}

shown that the external aperture of the ear is placed forwards in front of and below the eye.

The sexes are alike in colour and are reddish brown on the back, vermiculated with dark brown. The under parts are drab, barred with a darker shade. There is much individual variation in tint. Length $14.29 \mathrm{in}$; wing $7 \cdot 5$ in.

The young resemble their parents, but are rather more barred on the back.

\section{THE GREAT OR SOLITARY SNIPE}

\section{Gallinago major (J. F. Gmelin)}

A few individuals of this species, chiefly immature birds, visit our south and east counties yearly in autumn. Over the rest of the United Kingdom it is an exceedingly rare and irregular visitor.

It breeds in Scandinavia and across Northern Europe, extending southwards into Russia, Poland, and North Germany; over the rest of Europe east of the Rhone Valley it is common on migration and during the winter months.

It may be distinguished from the Common Snipe by its larger size, proportionately shorter legs and bill, and more boldly barred under parts. It has sixteen or more tail feathers. Length 10.5 in.; bill 2.3 in.; wing 5.5 in. 

WOODCOCK

Scolopax rusticula 


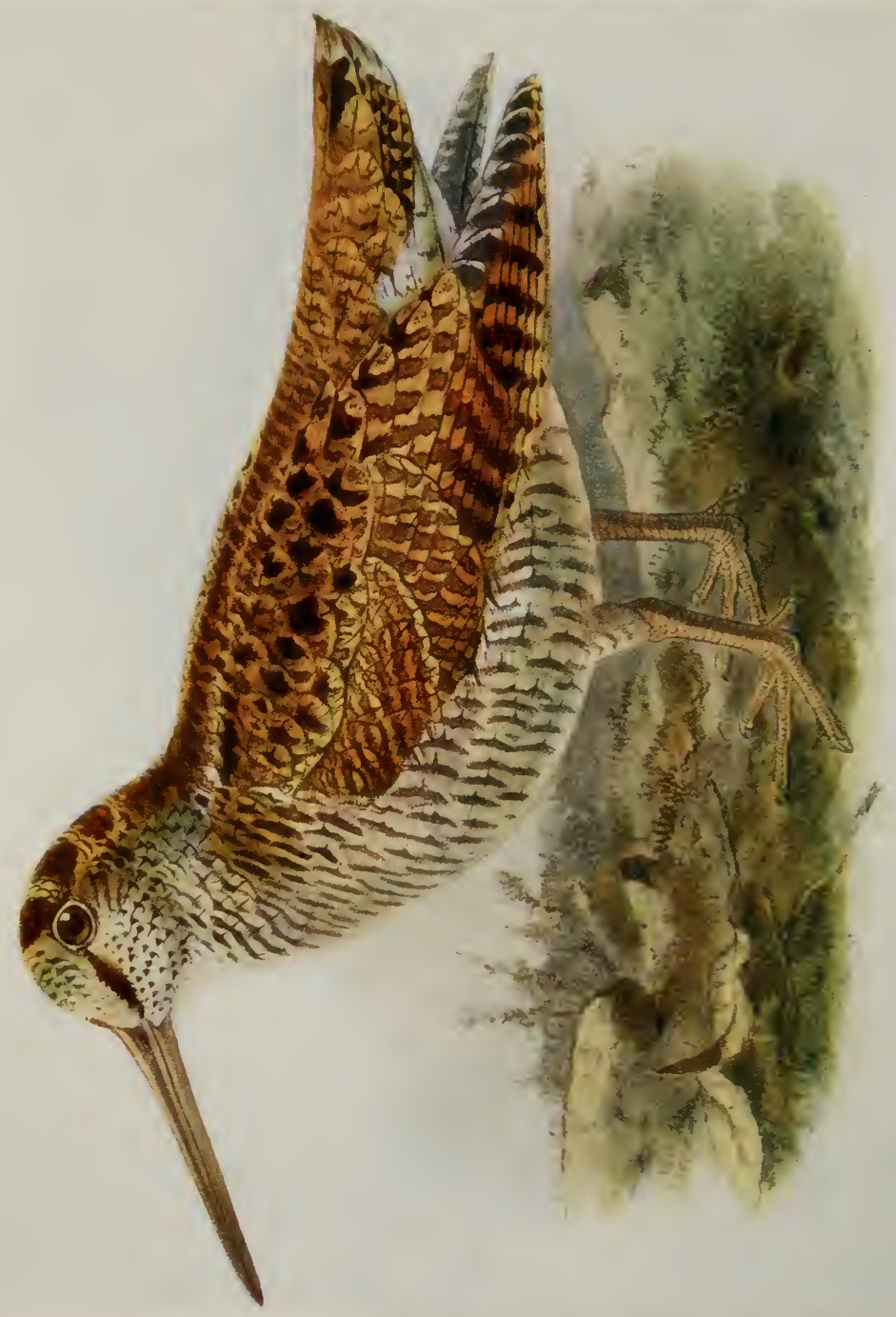





\section{The Common Snipe}

\section{THE COMMON SNIPE}

Gallinago cœlestis (Frenzel)

This bird is found wherever swamps, marshes, and damp meadows suitable to its habits are still left, and is a common resident throughout Great Britain, receiving large additions to its numbers from the Continent every autumn.

Very early in April it begins to nest, making a fairly deep "scrape" in a damp spot, generally in some rough grass or other cover, and lining it with a few bents and leaves. The eggs, four in number, as is the case with all wading birds, are greenish olive, spotted and blotched, often spirally, with various shades of brown, and there are also a few black markings near the larger end. The young when first hatched are reddish chestnut, mottled with black and white.

During the breeding season this species may often be seen "drumming" or "bleating." This is a sound much like the "bleating" of a goat, and considerable doubt as to how it was produced has long existed, although a Swedish naturalist stated many years ago that it was brought about by the rapidly vibrating tail feathers as the bird descended at a certain angle through the air. This has recently been clearly proved as correct by an English observer, Mr. P. Bahr, who points out that the sound is produced by the two outer tail feathers, which during the flight are held out widely separated from the rest of the tail. The sound can be produced artifici- 


\section{Birds of Britain}

ally by placing these feathers on a cork and rapidly whirling them round with a piece of string. During the breeding season it utters also a loud vocal "chip, chip," when on the ground, while when suddenly flushed the alarm-note of "scape, scape" is well known. Its flight is very rapid and direct when once on the wing, but on first rising it flies in short zig-zags, offering a very difficult shot. Sometimes, however, it will "squat" on the approach of danger, and even on a bare patch of mud becomes almost invisible, so well do its colours harmonise.

Its method of "squatting" is rather peculiar, for it puts its beak down and its body and tail well in the air and generally pressed up against some growing vegetation. In this position the two light dorsal stripes appear like blades of grass, and all trace of the contour and shape of the bird is lost.

The sexes are alike in plumage. The general colour above is' dark brown, with a light buff stripe across the crown and two stripes of a similar colour down the back, which is also mottled with buffish. Cheeks and chin are white, flecked with dark brown; chest and flanks ash brown; rest of under parts white. The young resemble their parents. Length 10.75 in.; bill 2.5 in.; wing 5 in.

There is a dark variety of this bird, known as Sabine's Snipe, which is occasionally met with, especially in Ireland. It has the whole of the under parts ash brown, barred with black, and the light stripes on the back are absent. Intermediates between the normal and the true Sabines are not uncommon. 


\section{The Jack Snipe}

\section{THE JACK SNIPE}

\section{Gallinago gallinula, Linnæus}

Breeding in the north-western corner of Europe, as far east as Archangel, the Jack Snipe is only a winter visitor to this country, arriving towards the end of October and often not leaving our shores till well on in summer, but there is no authenticated case of its ever having bred with us. In habits it closely resembles the Common Snipe, but lies much closer when being "walked up," and then rising at one's feet goes off at a great pace. It is a more solitary bird than the Common Snipe, and a single individual may often be found for a whole winter in the same spot.

During the breeding season it "drums" in the same manner as the Common Snipe, the noise having been compared to the cantering of a horse on a hard road. The eggs are similar in colour and only very slightly smaller than those of the Common Snipe.

It may be recognised by its short bill and smaller size, and from its having only twelve instead of fourteen tail feathers. Length 7.5 in.; bill 1.5 in.; wing 4.25 in.

\section{THE BROAD-BILLED SANDPIPER}

\section{Limicola platyrhyncha (Temminck)}

This species, although it may sometimes have been overlooked, is a very scarce wanderer to our shores. Nesting 


\section{Birds of Britain}

on the tundras of North Europe, it migrates eastward in winter to the shores of the Levant.

Its general appearance in winter is much like the Dunlin, but its somewhat flattened bill and the small amount of white on the secondaries and upper tail coverts form distinctive characteristics. Length 6.5 in.; bill 1.2 in.; wing $4 \cdot 25$ in.

\section{THE AMERICAN PECTORAL SANDPIPER}

\section{Tringa maculata, Vieillot}

The American Pectoral Sandpiper has occurred more frequently in Great Britain than any other of the American Sandpipers, some thirty or forty examples having been shot, and with two exceptions they have all occurred during the winter months.

Its breeding range is in Arctic America, whence it migrates to the tropics of America for the winter, and presumably those examples that visit us have come via Greenland, Iceland, and the Faroes.

The upper parts are brown, with lighter margins to the feathers; chin and throat whitish; breast buff, streaked with brown. Length 8 in.; bill 1.1 in.; wing $5.3 \mathrm{in.}$ 


\section{The Siberian Pectoral Sandpiper}

\section{THE SIBERIAN PECTORAL SANDPIPER}

Tringa acuminata (Horsfield)

The Siberian Pectoral Sandpiper is very closely allied to the above. It breeds in Eastern Siberia and is found in winter down the Asiatic coast. Two examples have occurred in England.

It differs from the American form in its smaller size and more rufous coloration, while the markings on the breast are arrow-shaped. Length $7 \cdot 4$ in.; wing 5.25 in.

\section{BONAPARTE'S SANDPIPER}

\section{Tringa fuscicollis, Vieillot}

This is an American species, breeding in Arctic regions and migrating in winter along the whole of the Atlantic sea-board of America. About a dozen examples have been procured in England and one in Ireland.

In appearance it is like a small Dunlin, but may be recognised by its smaller size, shorter bill, and white upper tail coverts. Length 7.25 in.; bill 0.9 in.; wing. 4.75 in. 


\section{Birds of Britain}

\section{THE DUNLIN}

\section{Tringa alpina, Linnæus}

Of all our shore-birds the Dunlin, or, as it is sometimes called, the Ox-bird, is the most numerous. At all times of the year and round all our coasts it may be seen running about and feeding on the animal life to be found among the rocks or in the soft muddy ooze recently left by the ebbing tide. It is almost always found in flocks, which are often made up of thousands of individuals, and when disturbed from one place they may be seen twisting and turning on the wing in graceful flight, preparatory to settling again on some rich feeding-ground. At times it is most absurdly tame, so that it is possible to walk right among a flock, which will continue feeding or resting as though unaware of the presence of a stranger. Suddenly an individual will sound the little alarm-note, and the whole flock will rise as though governed by one mind, even those who were asleep flying off in full possession of their faculties as though they had been on the alert all the time. In summer many leave us to nest in Northern Europe, while others betake themselves to inland moors or salt marshes round the coast on which to breed. It cannot be called a common nesting species with us, but it has been found in suitable places throughout the United Kingdom, becoming more numerous in the north.

The nest is a shallow "scrape" among heather, rough grass, or some other cover, and during the nesting season the 



\section{DUNLIN}

Tringa alpina

Winter (above). Summer (below) 


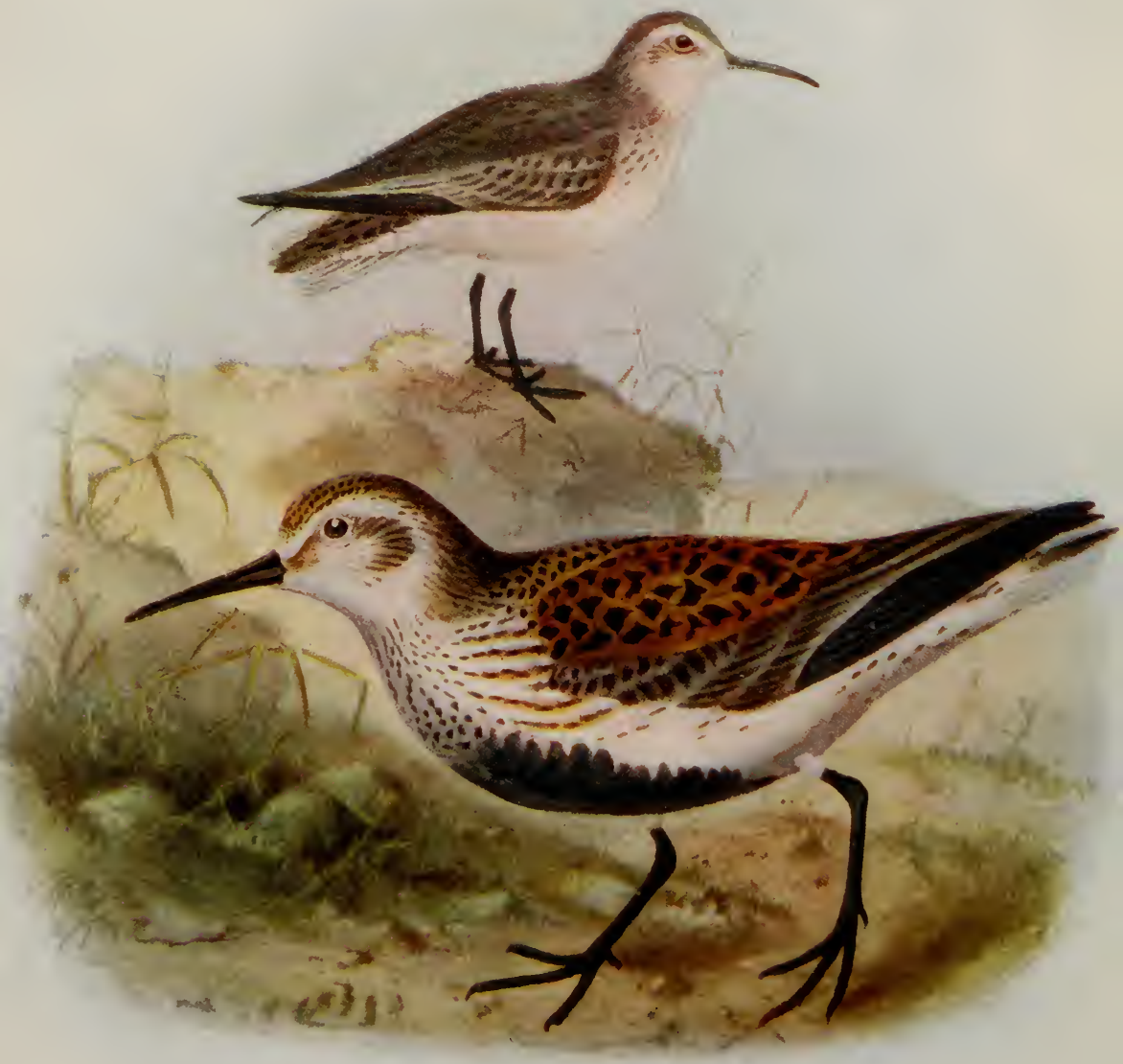





\section{The Dunlin}

male has a pretty little trill, which is generally uttered on the wing as he flies over the nest.

The eggs are greenish white, spotted and blotched with reddish brown. The young when first hatched are covered with reddish down, mottled with black and white.

In its winter dress the adult Dunlin is grey above and white below with a whitish bar across the extended wing. In spring the crown of the head is rufous, streaked with black. Mantle black, with broad rufous margins; the neck and throat white, streaked with black, breast black; belly white. The sexes are alike, the female being usually slightly the larger. Length about $7.5 \mathrm{in}$; bill $1.7 \mathrm{in.}$; wing $4.5 \mathrm{in}$. This species, however, varies greatly in size.

The young in autumn have the back nearly black, the feathers having narrow buff and rufous margins; the under parts are white, buff across the breast, and thickly spotted, especially on the lower breast, with black. The amount of spotting, however, as well as the colour of the breast, varies greatly in individuals.

\section{THE SEMIPALMATED SANDPIPER}

\section{Tringa pusilla, Linnæus}

A single example, the first to be recorded in Europe, of this American species, was shot in Kent on the 17 th September 1907. In general appearance it resembles a Little Stint, but is rather paler and more sandy in colour, and may easily be recognised by its longer bill and partially webbed toes. Length 5.6 in.; bill 0.85 in.; wing 3.7 in. 


\section{Birds of Britain}

\section{BAIRD'S SANDPIPER}

\section{Tringa bardi (Coues)}

This is an American species, and has recently been twice obtained in England.

In winter it closely resembles a Dunlin in general appearance, but is slightly streaked on the back. Its summer plumage is quite distinct. Length about 8 in.; wing $4 \cdot 7$ in.

\section{THE LITTLE STINT}

Tringa minuta, Leisler

This, the smallest of our shore-birds, is not a very common species. It occurs yearly on the autumn migration, along our eastern and southern coasts, but on the west it is very irregular in its appearance and decidedly rare. Its breeding-grounds are the tundras of Northern Europe, though it is decidedly scarce as a breeding species in the north-west; it winters in the tropical regions of the Old World.

In its habits and food it closely resembles the Dunlin, but its much smaller size enables it to be easily recognised.

In plumage it is practically a miniature Dunlin, but it lacks the black on the breast, which in the breeding plumage has a reddish tinge. Length 6 in.; bill 0.7 in.; wing 3.55 in. 


\section{The American Stint}

\section{THE AMERICAN STINT}

Tringa minutilla, Vieillot

This species has occurred in this country on two or three occasions. It is practically the counterpart of our species and can only be distinguished by its rather smaller size and darker colour. Length $5.25 \mathrm{in}$; wing $3.5 \mathrm{in}$.

\section{TEMMINCK'S STINT}

\section{Tringa temmincki, Leisler}

Although nesting much nearer to our shores than the Little Stint, this species is a very rare and irregular visitor to this country. It breeds commonly in Norway as far south as Trondhjem and eastwards across Russia beyond the limit of tree growth. In winter it migrates eastwards as far as India.

In appearance it is not unlike a very small Common Sandpiper, whereas the Little Stint resembles a small Dunlin. It may, however, be further recognised by the shaft of the outer primary being nearly white, and the two outer tail feathers being quite white. Length 5.75 in.; bill 0.6 in.; wing $3.8 \mathrm{in}$. 


\section{Birds of Britain}

\section{THE CURLEW SANDPIPER}

Tringa subarquata (Güldenstädt)

This bird arrives on our shores from the middle of August onwards, leaving us again in October, and a few are met with on the return journey in May. Although by no means as numerous as many other shore-frequenting migrants, it is not uncommon on certain parts of the coast, especially on the east and south, but is much rarer in the west. It may be recognised by its white rump and by the partially decurved bill, to which it owes its trivial name.

There is nothing to specially distinguish it in habits from the other species of Waders, and it will generally be found associating with Dunlins.

The breeding-grounds are in Arctic Siberia east of the Yenesei, and it winters in the tropical regions of the Old World.

In autumn the adult is brownish grey on the upper parts, white on the rump and under parts. The young birds may be recognised by the light margins to the feathers of the back and a buffish tint on the chest. In the spring plumage the upper parts are chestnut, streaked with black and grey. The under parts are chestnut, sometimes barred or spotted with brown, the feathers having white margins. Length 8 in.; bill 1.4 in.; wing $5 \cdot 1$ in. 


\section{The Purple Sandpiper}

\section{THE PURPLE SANDPIPER}

Tringa striata, Linnæus

The Purple Sandpiper is a winter resident on our rocky shores, and if somewhat local is nevertheless well distributed wherever suitable localities are found.

It has not yet been known to breed within the British area, but it is not unlikely that further investigation may prove that it does so on the Shetlands. Its nearest authenticated breeding-ground is on the Faroes; it breeds also in the north of Norway, Iceland, Greenland, and other circumpolar islands westward to Arctic America, but there is no evidence of its nesting in Siberia. The nest is placed on the sea-shore or on rocky fells near the margin of a lake, and the eggs are usually pale greenish buff, with reddish-brown markings. Both sexes incubate, and the male takes chief care of the brood; if disturbed after the young are hatched, the parent runs about in evident distress, and looks in the low scrub more like a rat than a bird. Their diet consists of insects, crustacea, and other living food, which may be found among the sea-weed growing on rocks; and the most exposed situations are visited as soon as the tide has uncovered the weed.

In summer the adult has the upper parts dark brownish grey, the feathers being spotted with rufous and tipped with whitish. The under parts from the chin to the breast dark grey, with brownish streaks; belly and flanks white, 


\section{Birds of Britain}

the latter spotted with brown. Three inner secondaries white, showing up conspicuously in flight. In winter the upper parts have a purplish gloss, and the breast is brown, with indistinct mottlings. The young have light margins to the feathers. Length 8.57 in.; bill 1.1 in.; wing 5 in.

The short legs give this bird a "squat" appearance and generally afford a clue to its identity.

\section{KNOT}

\section{Tringa canutus, Linnæus}

In autumn numbers of this species visit our shores, where for a few weeks it is one of the commonest birds, being found on all our coasts except in the west of Scotland. Large numbers leave us again after a few weeks' sojourn, but a fair number remain with us in wide estuaries or sheltered bays throughout the winter. A return migration takes place in spring, the birds being then in the full red plumage of the breeding season; but these soon pass on and only a few weakly and non-breeding birds are left with us during the summer.

For a long time the breeding home of this bird was unknown, and even although it was discovered breeding over thirty years ago, it is only within the last four or five years that authentic eggs have been obtained and brought home from East Siberia. Its chief breeding-grounds are the Arctic regions of North America and the north of 


\section{Knot}

Greenland, and in winter it is found down both sides of the Atlantic.

In its food and habits it does not differ from its congeners, with whom it may often be found associating.

In winter the adult is grey on the upper parts and white below, with a few greyish flecks or bars on the upper breast. The young bird is browner, with light margins to the feathers of the back, the breast pale buff pink, with a few grey flecks. In nuptial plumage the head and neck are reddish brown, streaked with black; upper parts black, the feathers having marginal spots of chestnut and white tips; under parts chestnut, spotted with black; vent and flanks whitish, mottled with hlack. Length $10 \mathrm{in.;}$ bill $1.5 \mathrm{in}$; wing $6.5 \mathrm{in}$.

\section{THE SANDERLING}

\section{Calidris arenaria (Linnæus)}

From its habit of frequenting sandy stretches along our shores, and less frequently near inland lakes, this species has gained its trivial name. To this country it is only a migrant, young birds arriving from their northerly breedinggrounds as early as the middle of August; the old birds follow a week or so later, many of them still retaining traces of the nuptial plumage. They stay with us only a short time, and early in October the majority have left us to winter on the shores of the Mediterranean, very few remaining behind. In May the return migration commences, 


\section{Birds of Britain}

but they only stay for a very short time to rest and then continue their journey to the Far North.

Their food consists entirely of marine insects, sandhoppers, and other crustacea, but at their summer-quarters large quantities of the northern saxifrage are consumed. It is very tame, allowing a close approach as it runs about on the sand, and appears conspicuously white among the Dunlins and other shore-birds with which it consorts. The note is a sharp "wick."

Its breeding range is entirely circumpolar, and the eggs are greenish, spotted with brown, not unlike miniature Curlew's.

In its winter plumage, in which it is most commonly met with in this country, the upper parts are pale grey and the under parts white. In its spring plumage the feathers of the back are black, with rufous margins; the chin, throat, and breast chestnut, with a few dark brown spots; vent white. In autumn the rufous edgings on the back of the old birds have almost entirely worn away. Length $8 \mathrm{in}$; ; bill 0.9 in.; wing 4.7 in.

This species may always be distinguished by the absence of the hind toe.

In autumn the young have the back black, spotted with white; the under parts white, with traces of buff on the sides of the breast. 


\section{The Ruff}

\section{THE RUFF}

\section{Machetes pugnax (Linnæus)}

Formerly this species used to be a regular summer migrant to our shores, breeding in the fen countries and other suitable places, but now, although a few birds visit this country in spring, and possibly a few may still breed, it is only as an autumn visitor that it will be generally found. Even on passage it can hardly be called common, but on our east and south coasts a good many pass through, halting merely for a few days. On the west and in Ireland it is decidedly rare and irregular in its appearances.

This species differs in its nesting habits from all other Waders. The males, who don a special showy ruff in spring, meet at their breeding-quarters on some raised mound and display their finery to the hens. Apparently they are very pugnacious, as they will often jump up and peck at another male, using their feet also after the manner of a gallinaceous bird, but on close observation it will be seen to be all "show," and we have never seen a proper fight between two males. On the arrival of a female the males spread out their ruff and remain motionless in front of her, and as she moves away they will jump up, and quivering with suppressed excitement again display their charms, to which she is apparently quite indifferent. Although said to be polygamous, the question is still open to doubt; from among her many admirers the female chooses one, and observations, so far as they go, seem to show that she only pairs with 


\section{Birds of Britain}

one male. A male, unless chosen, never pursues the female or interferes with her in any way, but trusts merely in his external beauty to attract her attention.

The nest is placed among rough herbage in a fairly damp place. It is a deep cup, well lined with grass and bents. The eggs, usually four but often three in number, are greyish green, blotched and spotted with various shades of brown. Except during the actual pairing the male takes no part in the housekeeping, and when the females are sitting the males may be seen together in flocks. In food and other habits this species resembles the majority of Waders.

In winter the sexes are alike, except that the imale is very much larger than the female. The upper parts are of a uniform brownish, and the under parts brownish grey, with white margins to the feathers; belly white. The young resemble the adults but are darker on the back, the feathers of which have rufous or buff margins. The neck and breast are of a pale pinkish buff.

In spring, the male grows a long ruff on the neck and upper breast as well as a backwardly directed ear tuft on each side of the head. This ruff can be raised or depressed at will, and is of a variety of colours, hardly any two being exactly alike. The face also becomes covered with a mass of warty carbuncles. The feathers of the back and flanks are black, mottled, spotted, or barred with chestnut. The female has no ruff, but becomes darker on the back and breast. Length of male 12.5 in. ; bill 1.5 in.; wing 7.25 in.: of female $10 \mathrm{in}$; wing 6 in. 


\section{The Buff-breasted Sandpiper}

\section{THE BUFF-BREASTED SANDPIPER}

Tringites rufescens (Vieillot)

Several examples of this American species have been obtained on our shores. This bird is somewhat like the preceding species although much smaller, but it may always be recognised by the black markings on both sides of the inner webs of the primaries and secondaries. Length $8 \mathrm{in}$; bill 0.9 in.; wing 5.25 in.

\section{BARTRAM'S SANDPIPER}

\section{Bartramia longicauda (Bechstein)}

This is another North American species, of which some eight or ten examples have been procured in this country.

Its general colour is pale tawny buff, barred and mottled with blackish. For a Sandpiper its tail is distinctly long and barred. Length 11.5 in.; bill 1.2 in. ; wing 6.6 in.

[We may note here that the Sandpipers we have hitherto been dealing with have had the tail plain, whereas in the remaining ones, which belong to the genus Totanus, the tail is barred.] 


\section{Birds of Britain}

\section{THE COMMON SANDPIPER}

Totanus hypoleucus (Linnæus)

This inland species, which is a summer migrant to our islands, is common and well distributed along the margins of lakes and on the gravel shores of streams and rivers. In the south and east, where suitable localities are scarce, it only occurs on migration, but elsewhere it breeds regularly.

The note is a plaintive "wheet, wheet, wheet," generally uttered on the wing. It is a very pleasing bird in its actions, running along the margin of the water and moving its body with a peculiar and delicate see-saw motion. When flying it remains fairly low down and follows the course of the stream, generally keeping over the water. Its food consists of worms, flies, and insects. The nest is placed on the ground, usually near the margin of some water, or on a rocky or gravel islet. The spot chosen is sometimes quite bare, or at other times thickly overgrown with brambles and rough vegetation. For a wading-bird it constructs a fairly substantial nest of grass and leaves, etc., and the eggs are of a pale clay buff, spotted with brown. The young when first hatched are greyish green with longitudinal dark stripes.

In August or early in September they begin to leave their summer-quarters and may then often be found in the salt marshes and on tidal ditches near the shore, but they do not remain there long, and by October they have all left, 


\section{The Common Sandpiper}

with the possible exception of a few stragglers that spend the winter in some of the south-western counties.

In summer the upper parts are bronzy brown, irregularly barred and flecked with blackish; sides of the neck and breast grey, with dusky streaks; rest of under parts white. In autumn the upper parts are uniformly brown, or nearly so, and the under parts lighter and with fewer streaks. The young have buff margins to the feathers of the back and lack the dark streaks on the throat. Length 8 in.; bill $1 \mathrm{in}$.; wing $4 \cdot 25 \mathrm{in}$.

\section{THE SPOTTED SANDPIPER}

\section{Totanus macularius (Linnæus)}

This American species has been recorded on several occasions in these islands. It is closely allied to the Common Sandpiper and resembles it in plumage, but in the spring dress it is more spotted on the under parts, and in autumn it is greyer above, and lacks the bronzy tint of our native bird. All the secondaries are barred with ash brown, whereas in the Common Sandpipers the eighth and ninth are nearly white. Length 7 in.; wing $4.2 \mathrm{in.}$

\section{THE WOOD SANDPIPER}

\section{Totanus glareola (J. F. Gimelin)}

This species is a regular but somewhat scarce visitor to our shores on migration. In Ireland and the west it is extremely 


\section{Birds of Britain}

rare, but in the south-east corner of England it occurs in small numbers yearly, especially in autumn. Formerly a few pairs used to nest in one or two suitable localities, but they have long ceased to do so. In the west of Europe it does not breed south of the Baltic, but in the east it breeds in the valley of the Danube and also possibly in Northern Italy.

The nest is placed on the ground in a marshy spot, and when they have eggs or young the birds are extremely noisy if their haunts are invaded. In this country it is generally found on salt marshes near the sea and very rarely inland.

The sexes are alike: the back brown, spotted with white; upper tail coverts white; shafts of the quills dusky, except that of the outermost one, which is white. Under parts white, streaked with brown on the throat and breast, the flanks being barred with the same colour. Axillaries white. The young bird is similar, but the white spots are larger and more elongated, and the outer tail feathers are barred on both webs instead of on the outer one only. Length $8.5 \mathrm{in}$.; bill $1 \cdot 1$ in.; wing 5 in.

\section{GREEN SANDPIPER}

\section{Totanus ochropus (Linnæus)}

This is a much commoner species than the last, and haunts inland streams, especially in the neighbourhood of trees and woods. It is most numerous during the autumn 


\section{Green Sandpiper}

migration, but many pass the winter with us, and it has been suspected of breeding on more than one occasion, but positive proof of this has not been forthcoming.

In the north and west of Scotland it is scarce, but otherwise it is widely distributed throughout the country. On the Continent it nests in marshy woods from the Arctic Circle southwards to Central Russia, Poland, and East Germany, its migrations extending to Africa in the winter.

In its nesting habits it differs from all others Sandpipers, for it lays its eggs in the deserted nest of some other bird, generally that of a Thrush, Blackbird, or Jay. The eggs are greenish grey, with small brownish spots. Its food consists of worms and insects.

In plumage it very closely resembles the preceding species, but the back is darker and the spots much more minute. It may, however, always be distinguished by the dusky shaft of the outermost primary and the brownish black axillaries. In young birds the spots on the back are less plentiful and of a more buffish tint. Length 9.5 in.; wing 5.5 in.

\section{THE SOLITARY SANDPIPER}

\section{Totanus solitarius (Wilson)}

This is an American species, which, like so many of its New World congeners, has occasionally and at long intervals straggled to these islands.

Its nearest ally is the preceding species, from which it may be recognised by having all the tail feathers, except 


\section{Birds of Britain}

the central pair, boldly barred with black. Length 8.25 in.; wing $5 \cdot 2$ in.

\section{THE YELLOWSHANK}

\section{Totanus flavipes (J. F. Gmelin)}

Two examples of this American species have been obtained, the first near Nottingham and the second at Marazion in Cornwall.

In general appearance it is not unlike a young Pedshank, but the legs are longer and more slender, and the axillaries are barred and not white. Length 10.75 in.; wing 6 in.

\section{THE GREATER YELLOWSHANK}

\section{Totanus melanoleucus (Gmelin)}

A solitary example of this species was shot on the 16th September 1906 at Tresco in the Scilly Islands. It is an American species and is not unlike a very large Redshank, but the legs are longer in proportion and yellow in colour. Length $12 \cdot 15$ in.; bill 2 in.; wing 8 in.

\section{THE COMMON REDSHANK}

\section{Totanus calidris (Linnæus)}

The Redshank is a common breeding species in suitable localities throughout our islands. 


\section{The Common Redshank}

In winter it occurs abundantly round all our coasts and causes much annoyance to shooters from its habit of flying up on the least alarm and warning all the other less wary fowl, with its shrill " tui too too."

The nest is usually situated on some inland marsh or low-lying grass field intersected with ditches. It is a very slight structure of grass and bents well concealed in a tussock of grass or tuft of rushes. The four eggs are of a pale stone colour, mottled and blotched with rich reddish brown. During the nesting season this bird becomes very noisy, and if the nesting site be approached, especially after the young are hatched, they fly round the intruder or sit on some bank, calling out vigorously all the time. It is a most interesting sight to take a sporting dog to where they have young and watch the way in which time after time these birds will decoy the dog away by fluttering under his very nose until they have led him to what they consider a safe distance, when they will spring in the air and with a cheery note return to their brood. This habit is common to many species and orders of ground-nesting birds, but unless we take a keen hunting dog with us we shall fail to realise what an excellent device it is for safeguarding the young from mammalian vermin. The food and habits of this species call for no special comment, as it does not greatly differ from its congeners.

In winter the adult is greyish brown on the back; secondaries nearly white; rump and under parts white, with a few dark streaks on the neck and breast. Bill black with a red tip; legs red.

In summer the upper parts are yellowish brown 


\section{Birds of Britain}

barred and spotted with blackish, the under parts white, profusely streaked on the neck and sides of the breast with ash brown, the flanks being barred with the same colour. Length 11 in.; bill 1.8 ; wing 6.25 in.

The female resembles the male, and the young may be recognised by the feathers of the mantle having buff spots and the legs being yellow.

The white secondaries are very conspicuous in flight.

\section{THE SPOTTED REDSHANK}

Totanus fuscus (Linnæus)

The Spotted Redshank is a rare migrant on both the spring and autumn migrations. In Scotland, Ireland, and the west of England it is almost unknown, but in the eastern counties a few probably occur every year on passage, but their stay is of such short duration that they are often unnoticed.

It breeds in the north of Scandinavia and Russia, laying its eggs in very dry situations at a considerable distance from its marshy feeding-ground. The young are, however, taken to the marsh as soon as they are hatched.

In summer the male has the upper parts black mottled with white, except the rump, and upper tail coverts, which are white, barred with black. Under parts black. Bill black, red at base of lower mandible; legs and feet deep red. The female at this season often has a white chin. In autumn the upper parts and neck are ashy brown 

REDSHANK

Totanus calidris

Adult, summer (right)

SPOTTED REDSHANK

Totanus fuscus (Linnæus)

Young in autumn (left) 


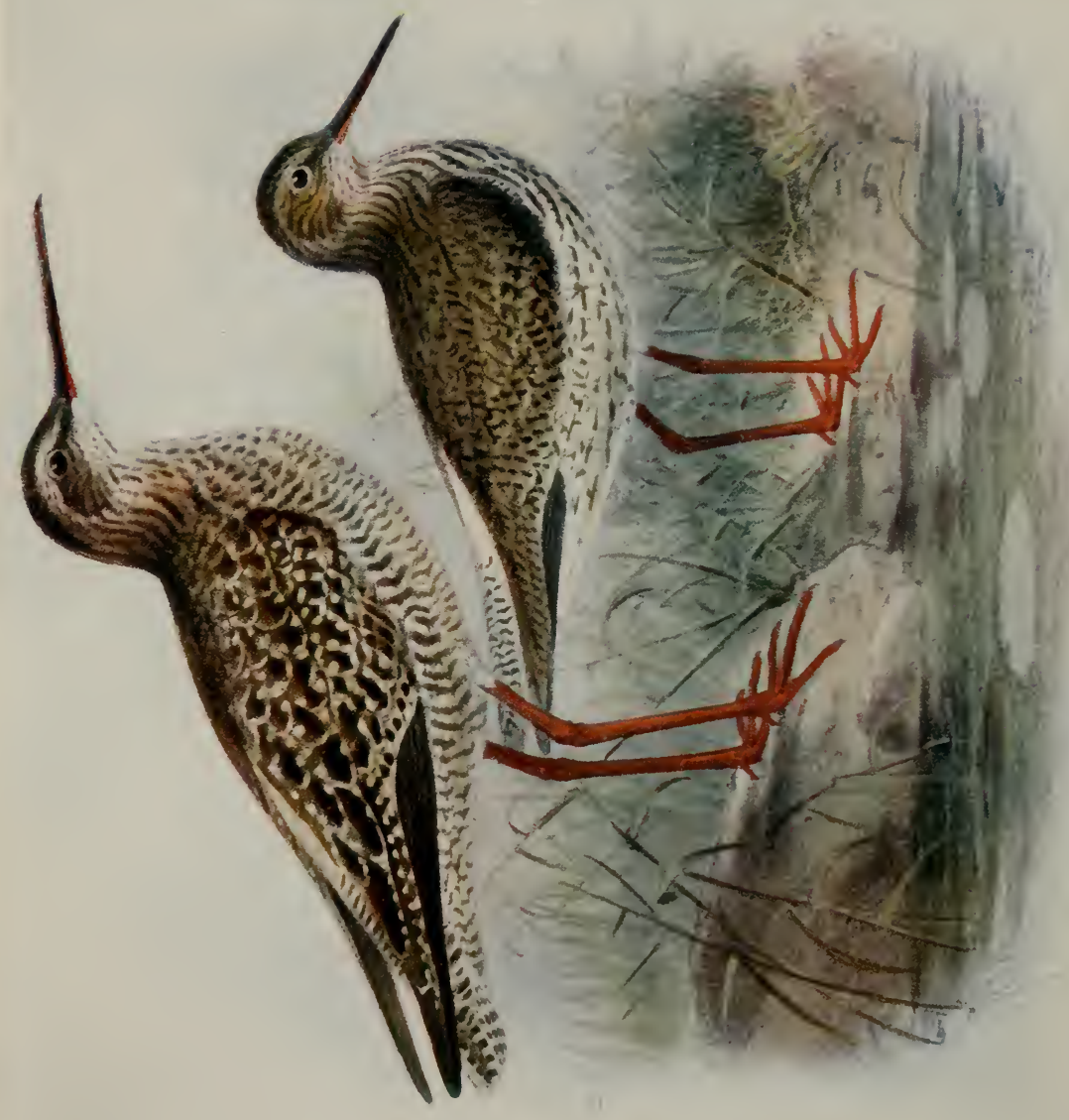





\section{The Spotted Redshank}

mottled with white; under parts white. The young differ from the autumn plumage of the adults in having the chin white and the rest of the under parts thickly barred with ash brown. Length 13 in.; wing 6.6 in. This species lacks the white wing bar.

\section{GREENSHANK}

\section{Totanus canescens (J. F. Gmelin)}

In a few places in Scotland where large tracts of pine forest exist some small boggy swamps varying in size from two or three acres to perhaps half an acre, may be found situated in the midst of the woods. These swamps form the summer home of the few Greenshanks that nest with us. The eggs are placed on a tussock in the centre of one of these bogs, so that to reach them is by no means an easy matter, and so cunning are these birds that they are seldom seen feeding on the swamp where they nest, but prefer to dine elsewhere. The eggs are generally of a light stone colour, boldly blotched and marked with darker brown. As soon as the young are hatched the parents remain in constant attendance, and should any one disturb the peace of their solitude, fly round, calling out incessantly. Amid such surroundings, therefore, be it in Scotland, Sweden, Finland, or elsewhere, the Greenshank is born, but as soon as he is able to fly at about five weeks old he departs with his parents for the nearest seashore where the mud-flats exposed at each tide afford him abundant nourishment. $\mathrm{He}$ is a wild and restless bird, and 


\section{Birds of Britain}

continually utters his clear " tui-tui" when on the wing. As a rule he is more partial to ditches filled and emptied at every tide than a broad flat expanse of mud, and by walking quickly along a ditch he may often be closely approached and watched as he probes the soft ooze for worms, shrimps, sandhoppers, or anything that may come handy. At the least sign of danger, however, he is off, calling out as he rises and displaying a very conspicuous white rump. Although liking to associate with others of his kind, his wild flight soon breaks up the family party, so that by the time he reaches our shores in August and September it is generally in twos and threes. The abundance of food on the shore has not been without its effect, and he is at this time of year exceedingly fat, doubtless a wise provision, as both old and young are moulting and migrating, which must be a serious tax on their system. They stay but a short time with us, and by the beginning of October the last of them has gone and their ringing "tui-tui" no longer enlivens the shore. In April they will return, but they are then anxious to reach their summer home, and brief as is their passage in autumn it is still shorter in spring, and if we wish to see them then it must be at their home in Scotland or farther north.

In summer the back is nearly black, each feather being margined with white; rump white; head white streaked with dark brown. Under parts white with a few blackish streaks on the throat and upper breast. In winter the back is greyer and the under parts are pure white. The sexes are alike. The young are browner on the back, and have buffish margins to the feathers. Length $14 \mathrm{in.;} \mathrm{wing}$ $7 \cdot 25$ in. 


\section{The Red-breasted Snipe}

\section{THE RED-BREASTED SNIPE}

\section{Macrorhamphus griseus (J. F. Gmelin)}

Some half-dozen examples of this American species have been met with in England, all of them during the autumn months.

At this time of year, except in size, it resembles a Dunlin; but in spring the under parts are chestnut, spotted on the breast, and barred on the flanks with dark brown. The feathers of the back are black, edged and barred with rufous. Rump and upper tail coverts white barred with black. The shaft of the outermost primary is pure white. Length 10 in.; wing 5.5 in.

\section{THE BAR-TAILED GODWIT}

\section{Limosa lapponica (Linnæus)}

On migration this species visits us in fair numbers, being found on low sandy shores and sheltered estuaries. A few remain throughout the winter, but by far the larger number pass on to Africa after a short sojourn. In May there is a return migration, especially along the east coast, the birds being then in full nuptial plumage.

It breeds in the northern portions of Europe, and in winter it is found throughout Southern Europe as well as in Africa. The note is a loud "louey, louey." 


\section{Birds of Britain}

In autumn the sexes are alike, and the general colour is brownish grey above and white below. The tail feathers are brown with no bars, but the tail coverts are barred at all seasons.

The young have a shorter beak than the adults, and are brown chequered with buffish above and dull buff below. The tail feathers are broadly barred.

In spring the male has the back blackish with tawny markings, the head and neck chestnut with dark streaks. Whole of the under parts deep chestnut, the sides of the breast spotted with brownish black. Rump white. Tail whitish with brown bars. Length 15.5 in.; bill 2.25 in.; wing $8 \mathrm{in}$. The female is much larger and has very little of the ruddy tint.

\section{THE BLACK-TAILED GODWIT}

\section{Limosa belgica (J. F. Gmelin)}

During the first half of last century this species used to nest in small but diminishing numbers in the fens and marshes of Lincolnshire and East Anglia. It is now only met with on passage, and even at such times it is by no means common, and in Scotland and Ireland it is scarce and its visits very irregular. On the Continent it breeds in South Scandinavia, Central Russia, Poland, North Germany, Denmark, and Holland, migrating during August to the Mediterranean basin.

Their food consists of insects and worms, which in this 346 


\section{The Black-tailed Godwit}

country are chiefly sought for in marshes near the shore. In the autumn plumage the general colour is ash brown above and greyish below. There is a conspicuous white wing bar, and the tail feathers are mostly black with white bases. In spring they have the mantle brown, mottled with black; head, neck and breast pale chestnut, the latter being barred with black. The female is considerably larger and rather duller than the male. The young in their first autumn resemble their parents, but have the neck and upper breast tinged with buff. Length 16 in.; wing 9 in.

\section{THE CURLEW}

\section{Numenius arquata (Linnæus)}

The Curlew is an abundant resident throughout the United Kingdom. In the winter it is essentially a shorebird, moving about in large flocks, which may be found in the meadows and pasture-lands near the coast; these flocks journey to the shore twice daily to feed on the mud or rocks left bare by the ebbing tide. In April it leaves the coast to nest on the heath-covered moors, and though it breeds in larger numbers in Scotland it is well distributed in the north and west of England and Ireland.

The nest is a shallow "scrape" with hardly any lining, and is placed among the heather or in a grass field. The four eggs are very pyriform in shape and are olive green in colour blotched with brown; the duties of incubation are undertaken by both sexes. It is extremely wary, rising on 


\section{Birds of Britain}

wing at the least alarm and calling out its loud "cour lie," which may be heard a considerable way off. Its food consists of worms, slugs, snails, and other insects, and when on the shore, small fish and crustacea are added to the bill of fare.

The general colour is a pale brown, with dark streaks; rump, vent, and upper tail coverts white. In winter the under parts are very pale in colour, almost white. The female is larger and the young in their first plumage are spotted rather than streaked on the back. Length 21-26 in.; bill 4·7-6 in.; wing $11 \cdot 5-12 \cdot 25$ in.

\section{THE WHIMBREL}

\section{Numenius pheopus (Linnæus)}

The Whimbrel only passes through these islands on migration, though a few pairs breed on the Orkneys and Shetlands. The spring passage generally takes place in May, from which it is known in some countries as the May-bird. In habits and food it closely resembles the Curlew, but its note is very different, being a rather melodious rippling whistle, which may be syllabled as "telly, telly, telly, tet." The fells of Arctic Europe form its chief nestinggrounds, whence it migrates in winter to the shores of the Mediterranean.

In plumage it is very similar to the Curlew, but may always be distinguished by having the crown of a uniform dark brown with a pale stripe down the centre. It is also 348 

CURLEW

Numenius arquata 


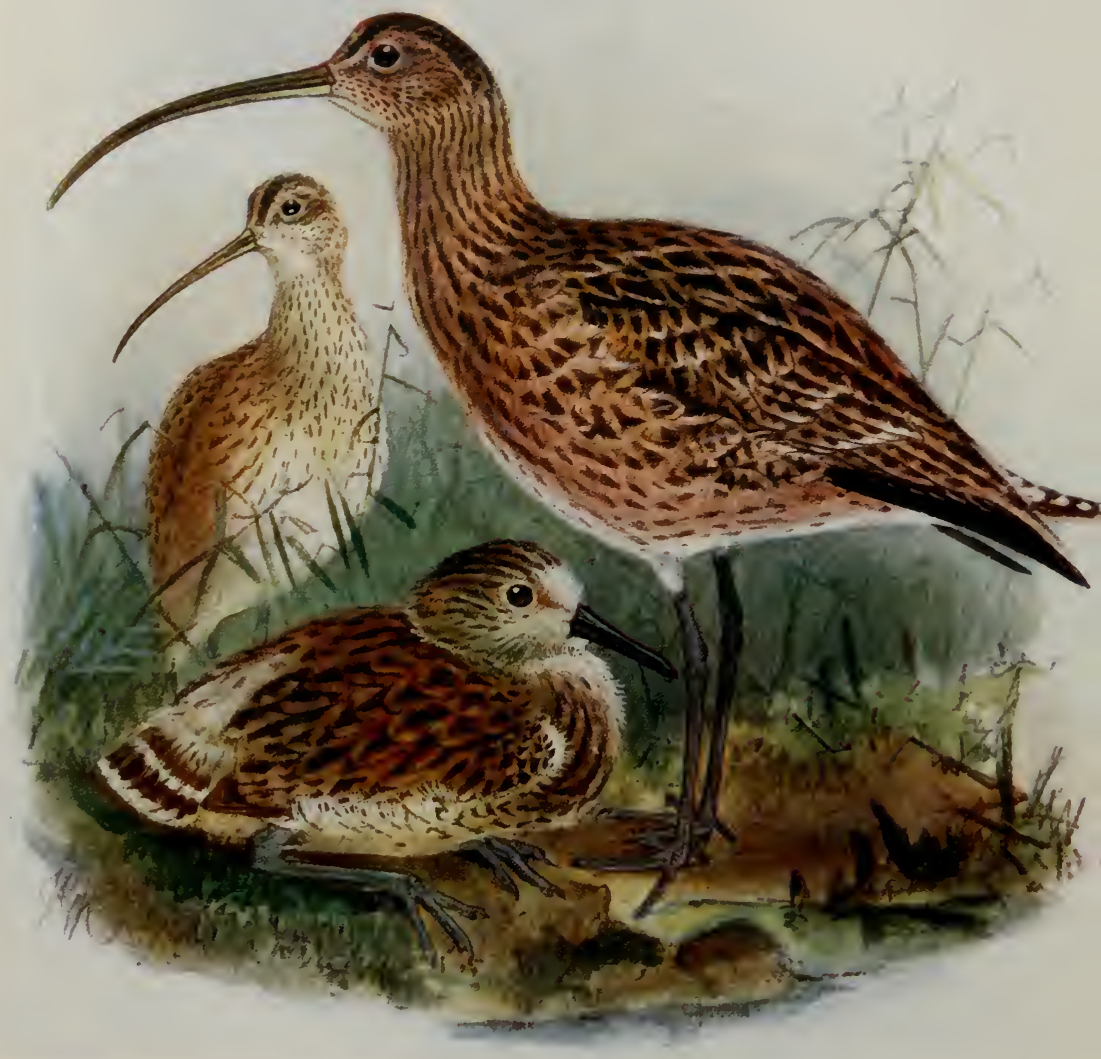





\section{The Whimbrel}

a much smaller species. Length 17.5 in.; bill 3.4 in.; wing $10 \mathrm{in.}$

\section{THE ESKIMO CURLEW}

\section{Numenius borealis (J. F. Forster)}

The home of this bird is in Arctic America, and some eight or nine examples have been procured in this country.

In appearance it is rather like a small Whimbrel, but it may be recognised by the absence of barring on the primaries, no white on the rump, transverse arrow-head markings on the under parts, and the axillaries being chestnut barred with brown. Length 14 in.; wing 8.25 in.

\section{THE BLACK TERN}

\section{Hydrochelidon nigra (Linnæus)}

Up till the middle of last century the Black Tern was a regular summer visitor to our shores, remaining to breed in the fens and marshes of England. For the last forty years, however, it has only occurred on passage, the adult birds passing through in April and May, and flocks in immature plumage being found along the east coast in the autumn. To the west of England and Scotland it is a very irregular visitor, and the same may be said of Ireland.

It nests in colonies on inland marshes, the nest being an accumulation of decaying vegetation floating on the surface of the water. The eggs, three in number, are olive green 


\section{Birds of Britain}

blotched with dark brown. Its food consists largely of aquatic insects and their larvæ, dragon-flies and such like, but it also feeds readily on small fish.

South of the Baltic it breeds in suitable localities throughout Europe, migrating from its more northerly summer quarters to Africa.

The adult in summer has the head, neck, and under parts dark greyish black, the rest of the plumage slate grey, except the vent and under tail coverts, which are white. Bill black. In winter the forehead, nape, chin, throat, and under parts are white. The young resemble the adults in winter, but the upper tail coverts are lighter and the back and wing coverts are greyish mottled with brown. Length 10 in. ; wing 8.5 in.

\section{THE WHITE-WINGED BLACK TERN}

\section{Hydrochelidon leucoptera (Schinz)}

This species, which is nearly allied to the preceding, breeds in the marshes of Central and South-eastern Europe. It is a very scarce and irregular visitor to our eastern and south-eastern shores, especially in spring.

In habits it resembles the Black Tern, from which it may be distinguished in summer by its red bill, white tail and tail coverts, and whitish wing coverts. The young may be distinguished from those of $H$. nigra by their longer toes and much paler rump and tail. Length 9.5 in.; wing 8.25 in. 


\section{The Whiskered Tern}

\section{THE WHISKERED TERN}

\section{Hydrochelidon hybrida (Pallas)}

This is a more southern species than its congeners, breeding in Spain, on the delta of the Rhone, and eastwards in Turkey, Greece, and South Russia. To our shores it is a very rare visitor, some half-a-dozen specimens only having been obtained.

In summer it is not unlike the Black Tern, but it may be recognised by the bill, which is stouter and red; the black of the head and nape is sharply contrasted with the grey of the back. A broad white stripe runs backwards from the base of the bill. Chin and throat grey, shading to black on the belly. In winter the forehead and under parts are white. Length 11.5 in.; wing 9.25 in.

\section{THE GULL-BILLED TERN}

\section{Sterna anglica, Montagu}

With this species we come to the true Terns or SeaSwallows, the preceding species being known as Marsh Terns. The Gull-billed Tern is only a very scarce straggler to our shores, being a southern European species though occurring yearly as far north as Denmark.

In habits there is nothing to distinguish it from our commoner species.

In summer the adult has the whole of the upper parts, 


\section{Birds of Britain}

including the tail, pearl grey; head and nape dense velvety black; primaries blackish. Under parts pure white; bill and legs black. In winter the head is white streaked with black. Length 15.5 in.; wing 13 in.

\section{THE CASPIAN TERN}

\section{Sterna caspia, Pallas}

This large Tern is, like the preceding, only a rare straggler to our shores. It nests in Denmark and various islands on the Baltic, as well as in the Mediterranean basin eastwards to the Aralo-Caspian area.

Plumage much as in preceding species, but the tail nearly white. Bill vermilion red; legs black. Length 20 in. ; wing 16 in.

\section{THE SANDWICH TERN}

\section{Sterna cantiaca, J. F. Gmelin}

This species arrives on our coasts about the middle of April and at once repairs to its breeding-stations. In England these are very few in number and mostly in the north, but occurring equally on the east and west coasts. In Scotland the colonies are rather more numerous, while Ireland can only boast of one in the north.

It nests on the bare shingle, the nests being usually placed quite close to each other. Two or three eggs of a pale stone colour, spotted and blotched with reddish brown and black, form the clutch. 


\section{The Sandwich Tern}

Like all Terns, this bird is a powerful flier, and seizes the fish on which it feeds by plunging into the water with considerable force. Its note is a loud and harsh "kirhitt," which may be heard some way off and often enables this species to be detected when among other Terns. It leaves our shores as soon as the young are well on the wing, and though a few stragglers may occur on the coast during the autumn it is by no means a common species, and needs all the protection it can get, if it is to remain an annual summer visitor to our shores.

The adult male in summer has the crown of the head black; the rest of the upper parts pearl grey; rump, tail, and under parts white, the breast being suffused with a delicate rose tint which soon fades after death. Bill black with a yellow tip. Legs black. The female is similar but slightly smaller. In autumn the back of the head and nape are white, the latter being lightly mottled. In the young the head is white mottled with black. The feathers of the back and wing coverts have black and brownish crescentic markings and white tips. The tail is also marked with angular lines of black, the outer feather being almost entirely greyish. Length 16 in.; bill 2.5 in.; wing 12 in.

\section{THE ROSEATE TERN}

\section{Sterna dougalli, Montagu}

This Tern still nests in small numbers round our shores, but it is extremely scarce and somewhat erratic in its choice of breeding-quarters, which often vary from year to year. 


\section{Birds of Britain}

It arrives very late in May, and leaves our shores as soon as the young can fly, so that it is not often met with on migration. It breeds sparingly on the coast of France, but its chief breeding-quarters are along the Atlantic coast of the United States.

In general habits it resembles its congeners, but it is an exclusively sea Tern, obtaining most of its food some distance out at sea.

In plumage it is almost indistinguishable from the two following species, but it may be recognised at all ages by the white inner margins to the primaries reaching the tip and even some little way up the outer web. The bill in the breeding season is black; legs and feet red. Length $15 \cdot 5$ in. ; wing 9 in.

\section{THE COMMON TERN}

\section{Sterna fluviatilis, Naumann}

This species arrives in May and nests in colonies round the whole of the coast as well as on some inland waters. In England it is the commonest Tern, but in Scotland and Ireland the Arctic Tern is almost if not quite as numerous, and both species may often be found nesting on the same island or beach.

Its food consists of small fish and crustacea, which it catches after the manner of all Terns by dropping down on them with closed wings from a moderate height.

They nest in colonies on rocks, shingle beaches, or near the margins of large inland waters, and very little attempt 

COMMON TERN

Sterna fluviatilis

Summer. Young flying 


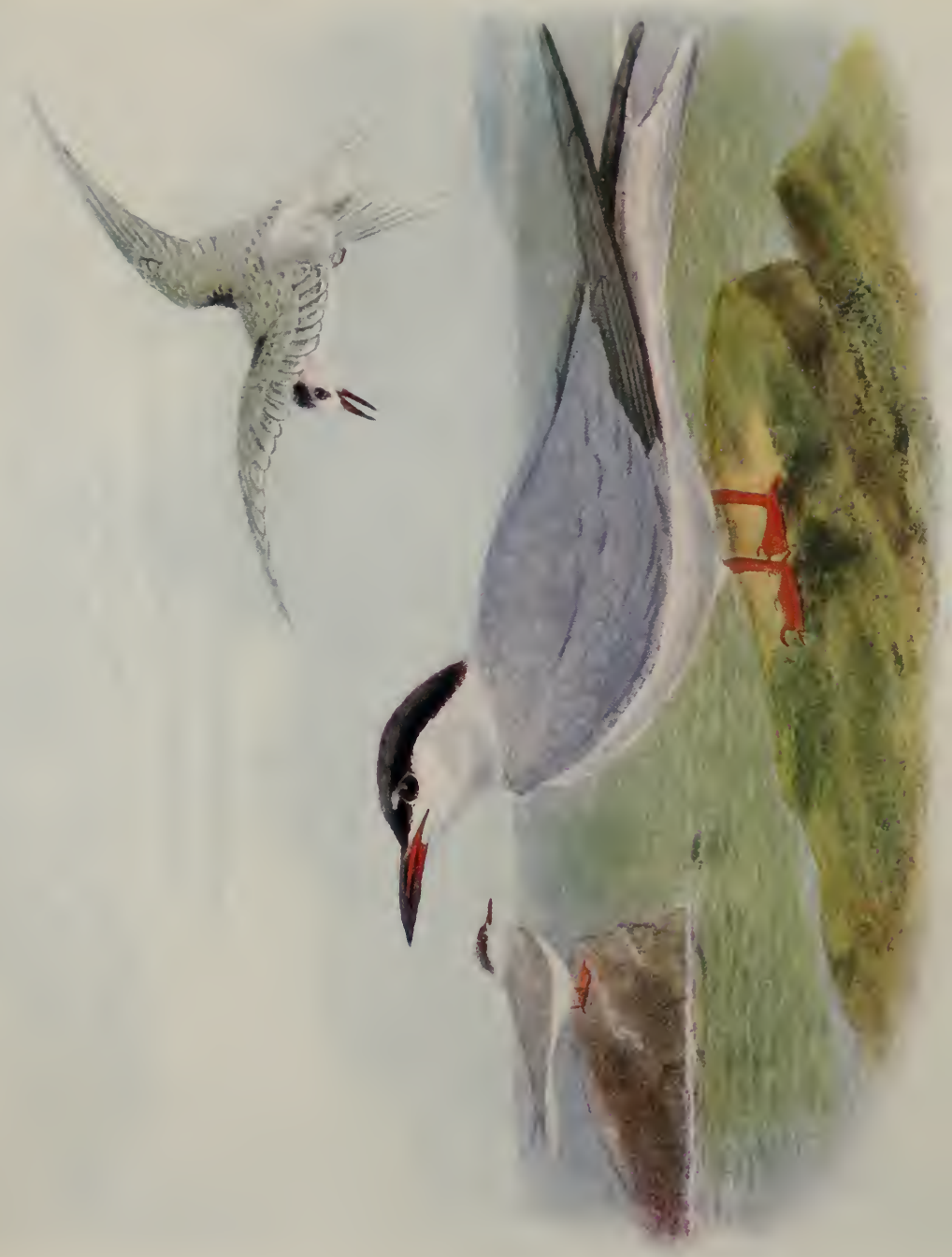





\section{The Common Tern}

at a nest is made, though this species almost invariably gathers a few bents together. The eggs are usually three in number, often only two, and are very variable in colour, being as a rule greenish or stone buff, with brown and grey spots and markings.

The note is a sharp "kik-kik," but during the nesting season they utter a loud "ee-arre," which is rather characteristic of this species.

The young are covered with pale brown down mottled with black, and leave the nest as soon as they are hatched, but they remain near the spot until they are fully fledged and well able to fly, as they are during that period entirely dependent on their parents for food.

Soon after the young can fly, old and young gradually disperse along the coast, slowly working southwards till by the beginning of October the last straggler has left for its winter quarters in Africa.

In summer the adult has the crown of the head and nape black, the rest of the back pearl-grey; rump white; tail feathers white with greyish outer webs. Under parts white tinged with grey. Bill orange red with horn-coloured tip; legs coral red. The sexes are alike. In winter the forehead is sprinkled with white and the under parts nearly pure white. The young in its first plumage has the head white; spotted with blackish brown, the feathers of the back pale pearl-grey barred with buff or brown and tipped with white; by late autumn, however, the back is pure grey with the exception of a dark band along the carpal joint. Bill and legs yellowish. Length 14.25 in.; bill 1.7 in.; tail 6.5 in.; wing $10 \cdot 5$ in. 


\section{Birds of Britain}

\section{THE ARCTIC TERN}

\section{Sterna macrura, Naumann}

Except in a few minor points of plumage and in its distribution this species is the counterpart of the preceding one. In England it is only met with on migration, though a few pairs may nest in the north, but in Scotland it is the commonest Tern, breeding in increasing numbers northwards. In Ireland it breeds commonly, especially on the wind-swept islets of the north and west. Elsewhere it breeds in circumpolar regions, and has been met with in winter in Antarctic seas, so that it has a latitudinal range of from $82^{\circ} \mathrm{N}$. to $74^{\circ} \mathrm{S}$., probably the largest range recorded for any one species.

Its nesting habits are similar to those of the Common Tern, and as a rule it collects absolutely no materials for a lining, but lays its eggs in a shallow "scrape" or even on the bare rock. The eggs are indistinguishable in colour from those of the Common Tern, but are on the average slightly smaller. To the experienced ear the note is also rather different, but that difference is too slight to be expressed on paper.

This species may be distinguished from the preceding species by its blood-red bill, which is not darker at the tip, and the shorter tarsi. The under parts, especially in summer, are much darker, and the stripe on the inner web of the flight feathers is narrower and darker than in S. fluviatilis. In other respects these species are almost indistinguishable. Length $14.5 \mathrm{in}$; bill $1.6 \mathrm{in}$; tail 7.5 in.; wing $10 \mathrm{in.}$ 


\section{The Little Tern}

\section{THE LITTLE TERN}

\section{Sterna minuta, Linnæus}

This is the smallest of our Terns and is a summer visitor, breeding in fair numbers on shingle beaches round the coast but becoming scarcer in the north.

It may often be seen fishing in small parties at the tidal mouth of some small stream, especially when the tide is flowing. At such times it flies slowly towards the sea till it sees a fish, when it stops, hovers for a moment, and then drops on its prey, rising immediately from the water to resume its search; after progressing a short distance it will wheel back and return to its starting-point.

The eggs are laid on the bare sand or shingle without any attempt at a nest; they are usually three in number and of a pale stone colour spotted with grey and brown. The note is a sharp "kik."

In summer the head and nape are black, except for the forehead, which is white. Upper parts grey, tail and under parts white. Bill yellow with a black tip. Legs orange.

The young have the head white, streaked with blackish brown, mantle grey with buffish tips, under parts white. In their first autumn plumage they are very similar to the young of the Sandwich Tern, the feathers of the back being marked with black, brown, and white. Length 9 in.; wing 6.75 in. 


\section{Birds of Britain}

\section{THE SOOTY TERN}

Sterna fuliginosa, J. F. Gmelin

Stragglers of this tropical species have on two or three occasions been met with on our coasts.

There is a white band across the forehead, which extends backwards over the eye on each side; rest of the upper parts deep sooty black; under parts white; outer web of outer tail feathers white. Bill and legs black. Length 17 in.; bill $2 \cdot 1$ in.; tail $7 \cdot 5$ in.; wing $11 \cdot 75$ in.

\section{THE NODDY}

\section{Anous stolidus (Linnæus)}

Like the former, this is a tropical species, which has on two occasions wandered to our shores.

The general colour is a dark chocolate brown all over except for the head, forehead, and crown, which are lavender grey. Length 16 in.; wing 10.5 in.

\section{SABINE'S GULL \\ Xema sabinii (Joseph Sabine)}

This circumpolar species is a very rare autumnal visitor to our shores. Its chief breeding-grounds are the Arctic $35^{8}$ 


\section{Sabine’s Gull}

regions of North America, whence it migrates southwards, in winter.

The adult has a slate grey back; the head and neck are very dark grey, tail and under parts white. In winter the forehead and crown are white. In their first autumn the young are ash grey on the occiput, nape, and back. The tail feathers have broad black tips. Length 13 in.; wing $10 \cdot 75$ in.

This species may always be recognised by the forked tail.

\section{THE WEDGE-TAILED GULL}

\section{Rhodostethia rosea, Macgillivray}

This extremely scarce Arctic Gull is said to have been obtained in Yorkshire on one occasion. It may be recognised by the wedge-shaped tail.

The adult is grey on the mantle; the rest of the plumage, except for a narrow black ring round the neck, is pure white. Length 13.5 in.; wing 10.25 in.

\section{BONAPARTE'S GULL}

\section{Larus philadelphia (Ordigny)}

This is a common North American species, of which some three examples have been taken in the United Kingdom.

In summer the adult has the head and neck black; 


\section{Birds of Britain}

mantle grey; tail and under parts white. The black on the head is lost in winter. Length 14 in.; wing 10.25 in.

This species may always be recognised by the white margins to the inner webs of the two outer primaries.

\section{THE LITTLE GULL}

\section{Larus minutus, Pallas}

This species, which is the smallest of our Gulls, is an irregular autumn visitor to our shores. It breeds in Northern Russia and possibly on some of the islands of the Baltic, migrating in winter to the Black Sea and Mediterranean.

In summer the head and neck are black; mantle grey, primaries grey edged with white, rest of plumage white except the underside of the wing, which is black and forms a distinctive characteristic in the adult. Length 11 in.; wing 8.75 in.

\section{THE BLACK-HEADED GULL}

\section{Larus ridibundus, Linnæus}

The Black-headed Gull is an extremely abundant species throughout the United Kingdom at all times of the year. In summer it resorts to various inland marshes and bogs, where it nests in immense colonies, some of which have been in use for centuries. In autumn and winter it is found all along the coast and up tidal rivers, a great many coming to 360 

BL.ACK - HEADED GULL

Larus ridibundus

Summer 


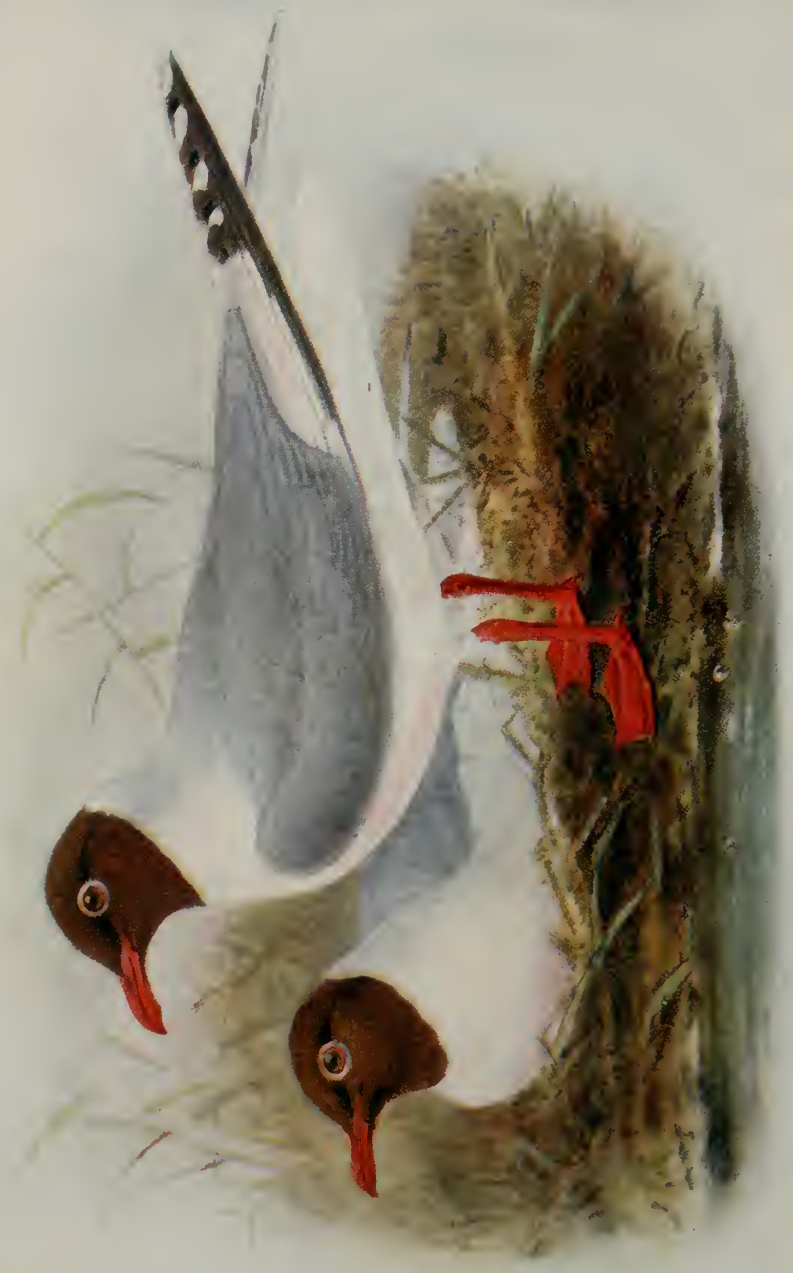





\section{The Black-headed Gull}

London, where they are extremely tame and show great agility in catching bread and other morsels of food thrown to them by pedestrians. The bird is practically omnivorous. When inland it follows the plough and feeds largely on worms and beetle grubs which are thus laid bare; but on the seashore, fish, crustacea, marine insects, and garbage are greedily devoured.

The nests are placed in a very wet and boggy place, surrounded, if possible, by water, but small ponds or tarns in marshy land are chosen in preference to large sheets of water. The nest is a large untidy heap of weeds and sticks. Four eggs, which are greenish, spotted and blotched with various shades of brown, form the usual clutch. The young hatch after about three weeks' incubation, and are covered with pale brown down mottled with black. They leave the nest when two or three days old, but for a week or ten days at least are entirely dependent on their parents for food; after that, however, though still fed by their parents, they pick up a good deal for themselves. They fly when about six weeks old. This gull is extremely noisy at all times, but when the nesting-ground is approached the babel of harsh screams is deafening. Although usually settling on the ground, this bird can perch with ease, and does so not infrequently when at its breeding haunts.

The sexes are alike, and in winter have the back pearl grey, wing feathers white with dark margins to the inner webs, head white with two indistinct dark crescents connecting the eyes and ears respectively, rest of the plumage white. Bill and legs white. In summer the head, with the exception of a narrow white circle over the eye, is dark brown. 


\section{Birds of Britain}

Bill and legs much darker than in summer. The young in their first plumage are mottled with pale brown, but soon become like the adult except for a black bar on the tail and pale brown wing coverts. The brown head is often only partially assumed in their first summer. Length 16 in.; wing 12 in.

\section{THE MEDITERRANEAN BLACK-HEADED GULL}

Larus melanocephalus, Natterer

This southern species has only once been taken on our shores, though, as it visits the west of France not uncommonly, there is no great improbability in its occurrence here. Its true habitat is the Mediterranean basin.

It is slightly smaller than the preceding species, and the head is jet black, not brown. The beak is also stouter. In young birds the first five primaries are chiefly dark brown, whereas in our species the shafts and contiguous portion of the inner webs are white. Length $15.5 \mathrm{in}$.; wing 11.75 in.

\section{THE GREAT BLACK-HEADED GULL}

Larus ichthyaètus, Pallas

This species is found in Egypt, the Levant, the Red Sea, and Persian Gulf, and only one example is known to have occurred on our shores. 


\section{The Great Black-headed Gull}

The large size and black head are sufficient to distinguish this species when adult; young birds may be recognised by the clear-cut dark band across the tail and by the white margins to the onter webs of the secondaries. Length of male $26 \mathrm{in}$; wing 19 in. The female is much smaller.

\section{COMMON GULL}

\section{Larus canus, Linnæus}

This bird is by no means the commonest of our Gulls, but may nevertheless be found in fair numbers along all our coasts in winter.

It does not breed in England, and in Ireland there are comparatively few colonies; but in Scotland, on the low islets round the coast as well as on the lochs and tarns inland, it is abundant in summer as well as in winter.

It usually nests in small colonies of six or eight pairs on some low-lying islet near the coast or on a lake, but it avoids during the breeding season precipitous coasts and exposed situations. The nest is placed on the ground and composed of a few bits of grass, seaweed, and heather without any attempt at concealment. The eggs, usually three in number, are olive brown streaked and spotted with blackish; like most Gull's eggrs, however, they vary considerably in colour. In food and habits it closely resembles the Black-headed Gull. Its ordinary note is a harsh cry, but during the nesting season it tries, somewhat feebly, to initate the well-known call of the larger Gulls. 


\section{Birds of Britain}

In summer the plumage, with the exception of the wings and mantle, is pure white. The mantle and most of the wing feathers are delicate bluish grey, but the three outer pairs of flight feathers are black with a white mirror towards the tip. Bill greenish with yellowish tip, legs greenish yellow. The sexes are alike, and in winter the head is flecked with brown. The young in autumn may be distinguished by the black bar on the tail and brownish wing coverts. Length about 17 in.; wing about 15 in.

\section{THE HERRING GULL}

\section{Larus argentatus, J. F. Gmelin}

This is the commonest of all our Gulls, and may be found abundantly throughout the year, round all our coasts. It nests in colonies, usually on the ledges of precipitous cliffs, although small low islets are occasionally resorted to. The nest is composed of grass, seaweed, and other vegetable débris, and the eggs, three in number, are greenish brown with brown and grey markings, but they are not infrequently of a uniform pale blue. Incubation is undertaken by both sexes. The young as a rule remain in or near the nest till fully fledged, but when the nest is low down near the shore they leave it much sooner. The Herring Gull is practically omnivorous ; fish, rats, crustacea, and garbage thrown up by the tide are all equally appreciated, and when nesting near colonies of Guillemots and Cormorants it systematically hunts the ledges and devours any uncovered eggs it can find. During the 364 

HERRING GULL

Larus argentatus

Summer 


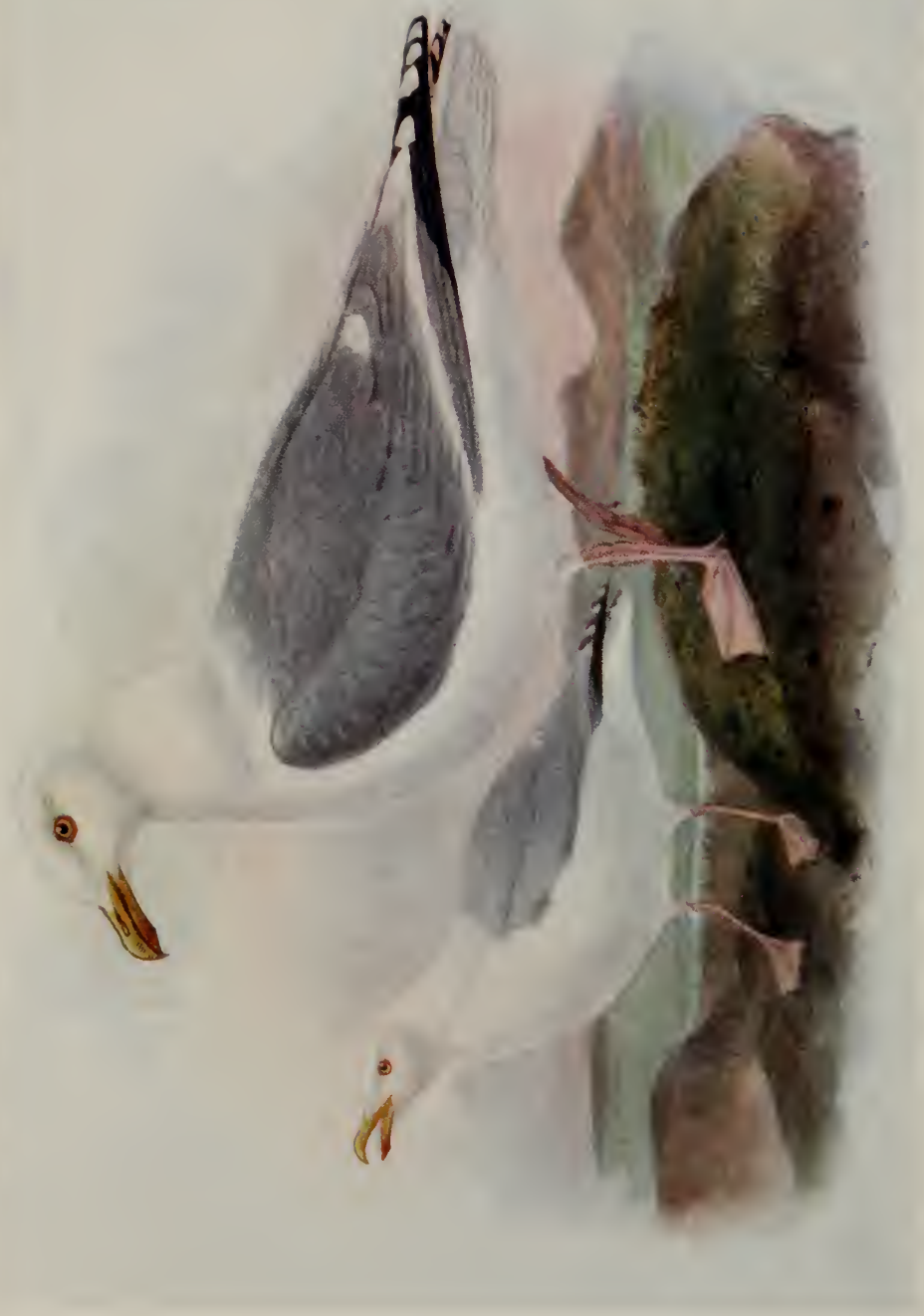





\section{The Herring Gull}

nesting season it is very noisy and utters a variety of cries; at times the head is bent right down and suddenly thrown up in the air with a loud "ollick, ollick," which cry is taken and repeated all over the colony. Young Gulls first commence to utter this note, which is not peculiar to the nesting season or to this species, at about three months old. If the colony be approached the birds utter a short "ow-ow"; the pairing note is a deep "mau," not unlike a cat's "miau," and a soft purring "ououou," the latter note being uttered while the bird sits down and toys with grass or other material at hand.

The adult in summer has the mantle French grey, secondaries grey tipped with white, outer primaries black with white tips and large subapical " mirrors." The rest of the plumage is white. Bill yellow with a red patch at the basal angle. Legs flesh-coloured. The female is said to be smaller than the male, but the difference is not always very apparent. In winter the head and neck are streaked with brownish.

The young in the first autumn are mottled all over with pale brown. They do not become fully adult until their fourth year, though they may sometimes breed in their third year. The adult plumage is assumed gradually, and there is much individual variation both as regards the time and method in which it is assumed. As a rule, however, some grey feathers appear on the back during the first summer; after the second autumn moult the under parts are chiefly white flecked with brown, but the back is chiefly brown. In their second summer much of the brown on the head and under parts is lost, the mantle becomes very grey, and 


\section{Birds of Britain}

the bill begins to show signs of yellow. The wing coverts and tail are, however, still very mottled.

After the third autumn moult the under parts, head, and neck are much as in the adult birds but more thickly mottled, the back chiefly grey, but the wing coverts, wings, and tail are still very brownish. In their third summer they are practically in adult plumage except for the wings and tail and a remnant of black on the bill. After the fourth autumn moult they are in full adult plumage except that the bill may still show some traces of black and occasionally the tail has some brown flecks, but by the time their fourth summer comes round they are in full adult plumage and breed.

Immature birds are seldom seen among colonies of adults during the summer, and it is still somewhat doubtful where they spend the summer; possibly round some islets out at sea where food is plentiful. Length $24 \mathrm{in}$; wing $17 \mathrm{in.}$

\section{THE LESSER BLACK-BACKED GULL}

\section{Larus fuscus, Linnæus}

Very closely allied to the Herring Gull, this species is tolerably common everywhere, but is rather more local in the breeding season. In England it nests but sparingly and only in the west, but in Scotland it becomes much more abundant, and in some districts commits considerable havoc among the game-birds on the moors.

It chooses for its breeding-quarters some grassy slope on the top of the cliffs or on an islet in one of the numerous 366 


\section{The Lesser Black-backed Gull}

firths in the west of Scotland. In Ireland it is generally distributed and nests sparingly round the coast. In all its habits this species so closely resembles the Herring Gull that further description is unnecessary.

The adult only differs from the preceding species in being black on the mantle and wing coverts, and in the colour of the legs, which are yellow. Length 22 in.; wing 16 in.

It is almost impossible to distinguish the young of this species in their first autumn.

\section{THE GREATER BLACK-BACKED GULL}

\section{Larus marinus, Linnæus}

This species may be found during the winter on almost any part of our shores, but it is by no means so abundant as the Herring Gull.

As a breeding species in England it is rather scarce, chiefly owing to lack of suitable places, but in Scotland it is abundant. It is a bold and majestic species, with a fine soaring flight, but we must acknowledge that it is terribly destructive to weakly lambs and young water-fowl. Practically omnivorous, nothing comes amiss to this rapacious bird, and its food consists largely of carrion and other refuse of the shore. Although it has often been denied, this and other species of Gulls can completely immerse themselves and pick up food from the bottom in at least three feet of water, and we have repeatedly observed 


\section{Birds of Britain}

them do so in captivity. Having marked some food at the bottom of the water, they rise to a height of about four feet and forcibly precipitate themselves into the water with halfopen wings; they are nevertheless extremely buoyant, and occasionally bob up on to the surface again before they have attained their object.

An isolated "stack" or islet in a loch is commandeered by a pair of these birds for their summer home. The nest, composed of grass and rubbish, is usually placed on the highest point. They lay two or three eggs, which are stone buff in colour, blotched and spotted with light brown and grey.

The most usual note is a deep "ow, ow, ow." In plumage the adult is almost the counterpart of the preceding, but the legs are flesh-coloured. Length 23 in.; wing 19 in.

The young are mottled and barred with various shades of brown and buff, but are rather lighter in colour than those of the Herring Gull. The adult plumage is assumed by precisely the same stages as in the other species, and they may occasionally become fully adult in their third summer.

\section{THE GLAUCOUS GULL}

\section{Larus glaucus, 0. Fabricius}

This large white-winged Gull is an annual visitor to the north of Scotland, but southwards it becomes scarcer, and it is only in very severe weather that it visits the south of 

GREATER BLACK - BACKED GULL

Larus marinus

Summer (right). Young, first autumn (left) 


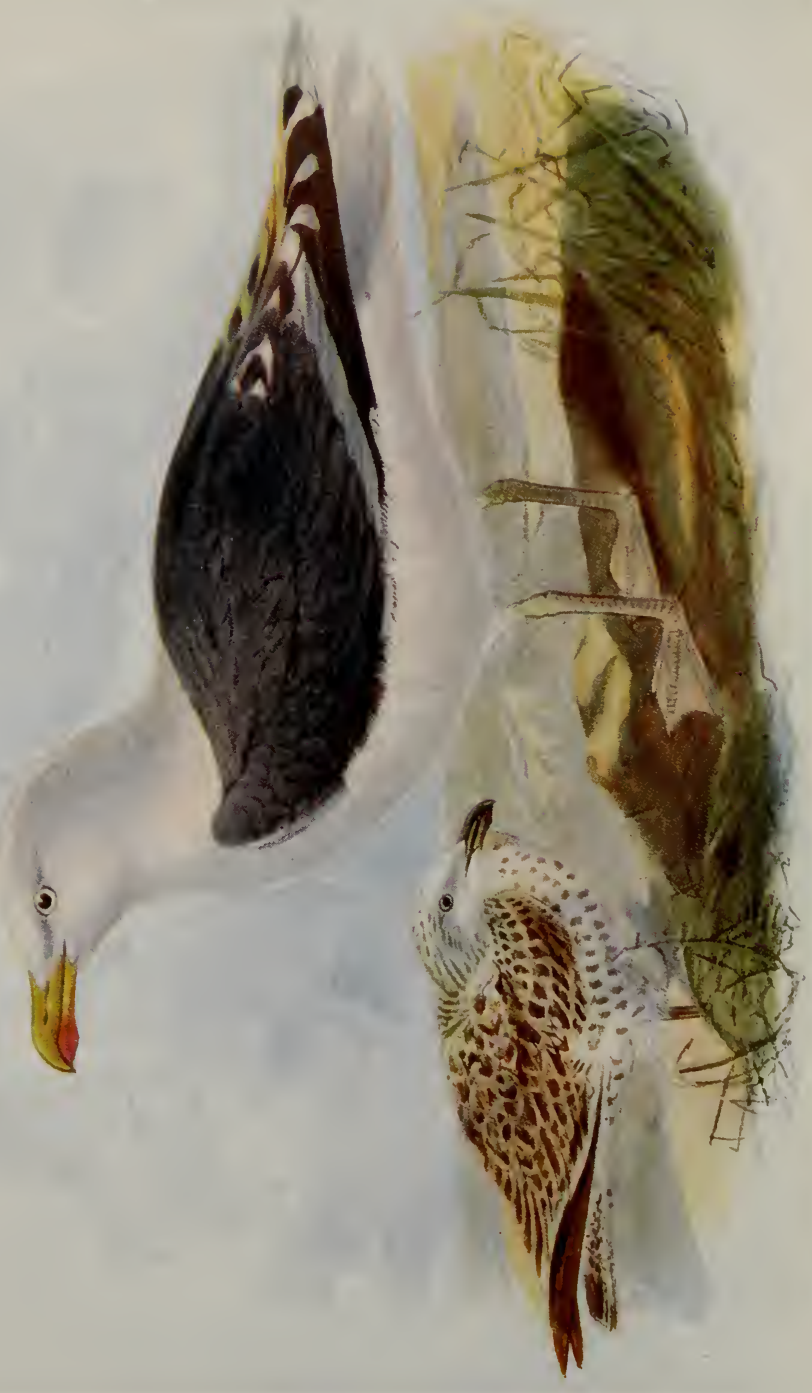





\section{The Glaucous Gull}

England. Its breeding range is circumpolar, its nearest breeding-place to our shores being in Iceland.

The mantle and wings are pearl-grey, with white tips to the secondaries and outermost webs of the quills. Orbital ring vermilion. Legs pink. Immature birds are whitish uniformly and thickly mottled with ash grey. Length 29 in. ; wing 18 in.

\section{THE ICELAND GULL \\ Larus leucopterus, Faber}

This species is very closely allied in plumage and habits to the preceding. It is a winter visitor to the shores of Scotland, only coming south in severe weather. It breeds on Jan Mayen Islands and Greenland, and is only a winter visitor to the island whose name it bears.

Except in size it is almost a counterpart of the Glaucous Gull, but the orbital ring is flesh-coloured, and the legs yellowish. Length 22 in.; wing 16 in.

\section{THE KITTIWAKE GULL}

\section{Rissa tridactyla (Linnæus)}

With the Kittiwake we come to a species of Gull which differs in its general build from those we have hitherto dealt with. It is rather shorter in the leg, which gives it a 


\section{Birds of Britain}

somewhat "squat" appearance, and it does not run about on land with the same facility. In correlation with this we find it to be a much more pelagic species, and though found commonly round our shores, it gets most of its food on the water and is rarely to be found among the large flocks of other Gulls that spend much of their time on the shore itself. Its food consists almost entirely of fish, in pursuit of which it dives and swims under water with ease.

It nests on the ledges of precipitous cliffs in immense colonies, and in some cases the population of these colonies must amount to very many thousands. The nest is built of seaweed and other flotsam, and is often larger than the narrow ledge on which it is placed. The eggs, two or three in number, are usually pale greyish white, blotched and zoned with ash grey and brown; the shell is rougher in texture than in the other species. They are laid very late in the season, so that it is generally July before the young are hatched. Both sexes take part in the incubation, and the young are entirely nidicolous, not leaving the nest till they are well able to fly.

In summer the adults very closely resemble the common Gull, but it is a smaller bird, and the black legs, on which the hind toe is absent, form an unfailing characteristic. In winter the nape and hind neck are grey like the mantle. Length 15.5 in. ; wing 12 in.

The young bird in its first autumn has the nape greyish but darker than in the adult, and the wing coverts and inner secondaries are thickly spotted with brownish black. 

KITTIWAKE

Rissa tridactyla

Summer (below). Winter (above) 


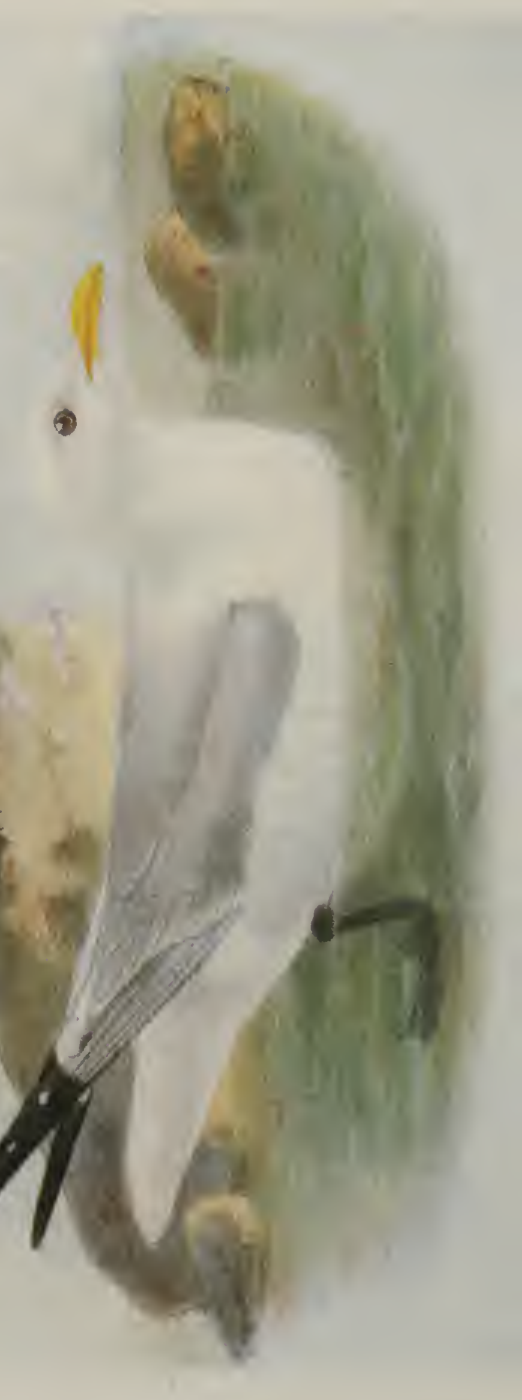




\section{Birds of Britain}

of all shades are found. The central tail feathers are longer than the rest. Length 20 in.; wing 13 in.

The young vary considerably, but are usually brown, mottled and spotted with chestnut, while in some the chestnut colour is almost entirely wanting.

\section{THE LONG-TAILED OR BUFFOUS SKUA}

\section{Stercorarius parasiticus (Linnæus)}

This is a rare species to all our shores, but a few, chiefly immature birds, visit the east coast yearly, and in some seasons become quite common. It is a circumpolar species, breeding on the tundras throughout Europe, Asia, and America, and migrating in winter as far south as the basin of the Mediterranean.

In its habits it resembles other Skuas, but in addition to robbing Gulls, it feeds largely on beetles and worms, and the young eat a large quantity of crowberries when in their summer-quarters.

The adult has the top of the head black, cheeks and hind neck buffish yellow, mantle and tail, the two central feathers of which are much elongated, grey brown, wings darker. Under parts chiefly white, brownish on the flanks and belly. Length $23 \mathrm{in.}$; tail 8.5 in.; wing 11.9 in.

Immature birds are barred above and below with brown and yellowish white. It is sometimes rather difficult to 



\section{RICHARDSON'S SKUA}

Stercorarius crepidatus

Adult (above). Young (below) 


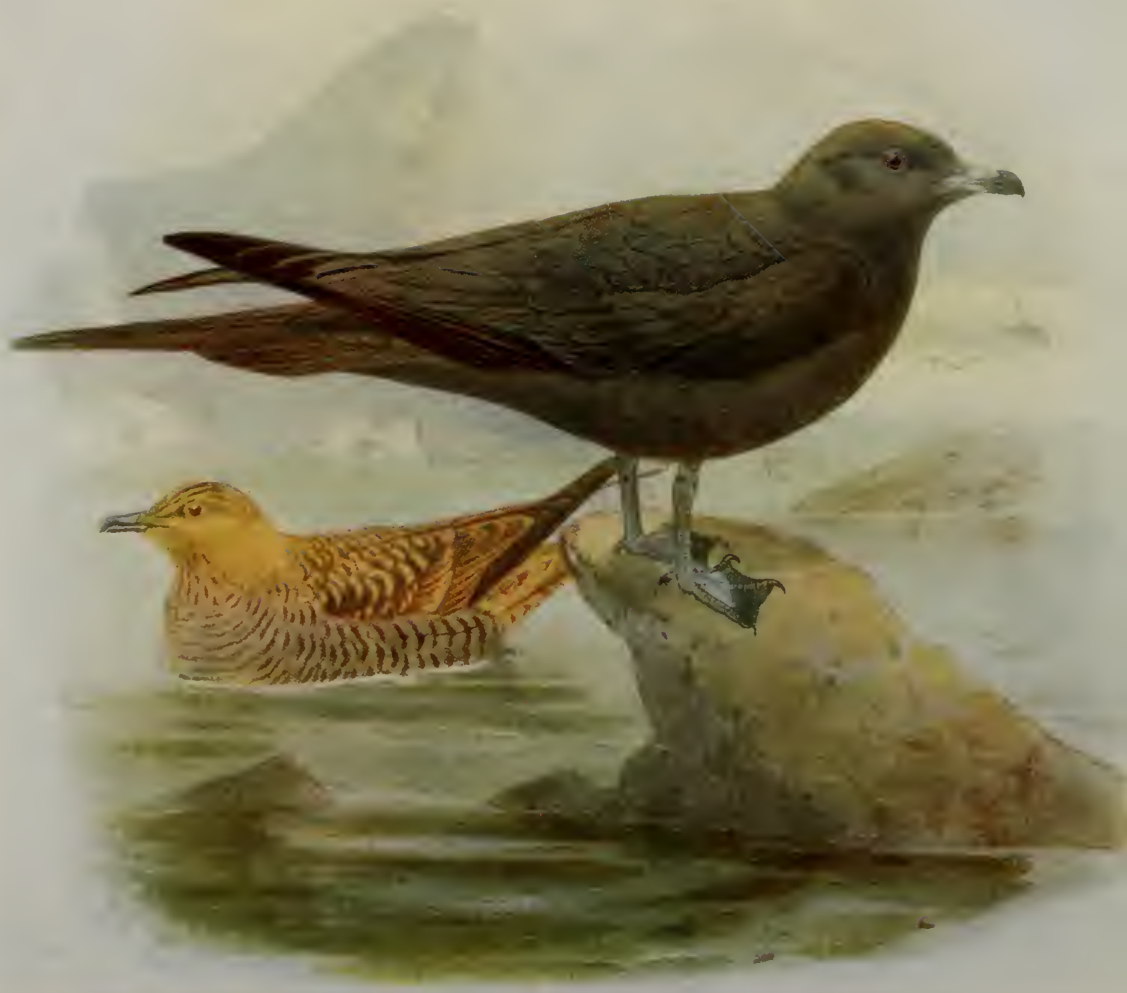





\section{The Long-tailed or Buffous Skua}

distinguish between the young of this and the preceding species; the present species is, however, always much greyer and less rufous, and has the shafts of the two outer primaries white, the rest being dusky, whereas in the Arctic Skua the shafts of all the primaries are white.

\section{THE RAZORBILL}

\section{Alca torda, Linnæus}

The Alcidæ are pre-eminently pelagic birds that spend their whole life out on the ocean except for a few short weeks every year, when they assemble in thousands on precipitous cliffs to breed.

During most of the year the Razorbill lives far out at sea in the Atlantic, never coming within sight of land unless driven inshore by some winter's gale.

It is an expert swimmer and diver, and though it flies well and swiftly with rapid beats of its small wings, it rarely avails itself of that means of progression. It feeds entirely on small fish. Early in April it repairs to the cliff where it is to breed, but it is not until May that the large single egg is deposited in some nook or recess of the cliff often quite hidden from view. If, however, suitable recesses are not handy, it will content itself with an open ledge. The egg is white or buffish in ground colour, boldly marked with chocolate brown and black. Incubation, which is carried on by both sexes, lasts about five weeks. The young bird when first hatched is covered with short down 


\section{Birds of Britain}

and is blackish on the back, white beneath, and yellowish on the head. It remains in the nest for about three weeks, by which time it is covered on the back and breast with downy feathers and has tiny wing feathers caused, as in the case of the game birds, by the rapid growth of the primary wing coverts.

At this age the young may be found in the sea, having presumably been carried down by their parents; they can swim readily, but it is said that unless forcibly made to dive by their parents they remain on the surface. In captivity, however, they dive without hesitation on the least sign of alarm, using both wings and feet, and progress with considerable rapidity under water.

At the age of about two months the flight feathers proper begin to grow, and then the autumnal moult takes place.

In summer the adult has the head, neck, chin, throat, and back deep blackish brown, a narrow line from the eye to the culmen white, and the rest of the under parts white. The bill is black and vertically flattened; it has two or more grooves near the tip that are whitish. It varies greatly in size, and is much larger in some individuals than in others, this difference being probably due to age. The sexes are alike, and in winter the chin and throat are white. Except in the size of the bill, the young bird resembles the adult after the first moult. Length $17 \mathrm{in.}$; wing $7 \cdot 3 \mathrm{in}$. 

RAZORBILL

Alca torda

Adult (left). Young (right) 


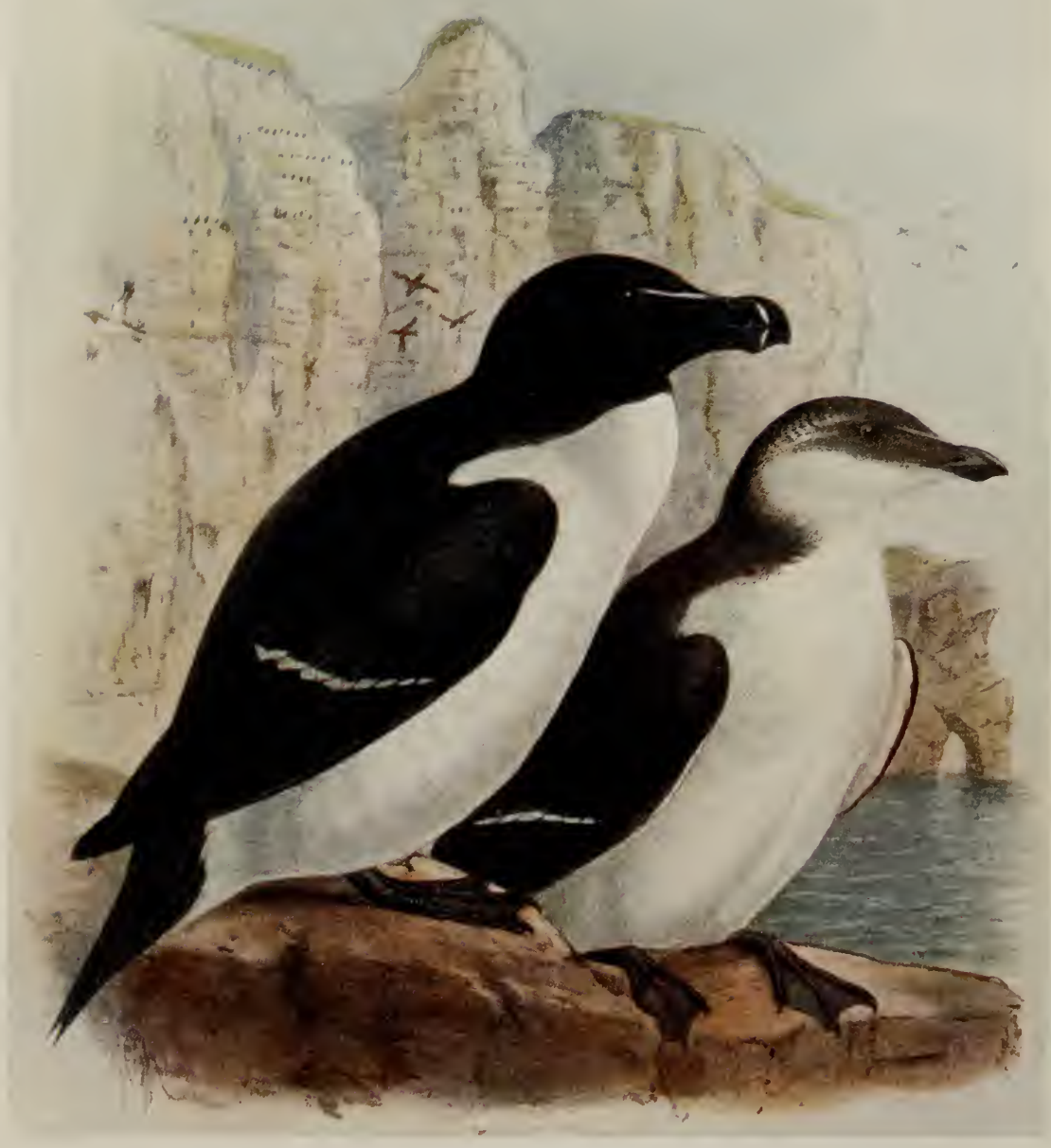





\section{The Great Auk}

\section{THE GREAT AUK}

\section{Alca impennis, Linnæus}

So much has been written on this now extinct species that it need hardly be mentioned here.

The last living example was killed off Iceland in 1844 , and the last British example was captured in $183 \pm$ in Waterford Harbour.

In former times it was abundant round Newfoundland, and especially on Funk Island, where the fishermen used to salt it down for food, and soon extirpated it.

In appearance it was like a large Razorbill, but it had very small wings and was quite incapable of flight. The lores and under parts were white, upper parts black. Length 32 in.; wing 4.25 in.

\section{THE COMMON GUILLEMOT}

\section{Uria troile (Linnæus)}

In its habits, food, and actions this species closely resembles the Razorbill, and they are usually found breeding on the same cliffs. The numbers at a colony can only be reckoned in countless thousands, the birds sitting crowded together as close as possible.

This species lays its egg on the bare open ledges and never seeks the nooks and recesses made use of by the 


\section{Birds of Britain}

Razorbill. The eggs are very pear-shaped, a wise provision which prevents their rolling off the narrow ledges on which they are laid. In colour they are most variable; the commonest variety is greenish in ground colour with brown or black streaks and markings; cream varieties somewhat resembling those of the Razorbill are not uncommon, but they may always be distinguished by the yellowish white lining membrane, whereas in the Razorbill the membrane is greenish.

The young bird when first hatched is covered with irongrey down on those parts of the body which are brown in the summer dress of the adult. The under parts are white and there are a few bits of white down on the head.

In its habits and moults it resembles the young Razorbill.

In summer the adult has the upper parts, chin, and throat dark brown, and the rest of the body white. The black bill is long, pointed, and sharp, and not flattened as in the Razorbill. At the autumnal moult the brown on the chin, throat, and back of the head is replaced by white, and in this and the other allied species all the flight feathers are moulted at the same time. Length $18 \mathrm{in.}$; wing $7.5 \mathrm{in}$.

There is a curious variety of this bird known as the Ringed or Bridled Guillemot, which may be distinguished in summer by having a narrow white ring round the eye which stretches backwards for a short distance along the feather crease behind it. 

COMMON GUILLEMOT

Uria Troile

Adult, summer (left). Young (right) 


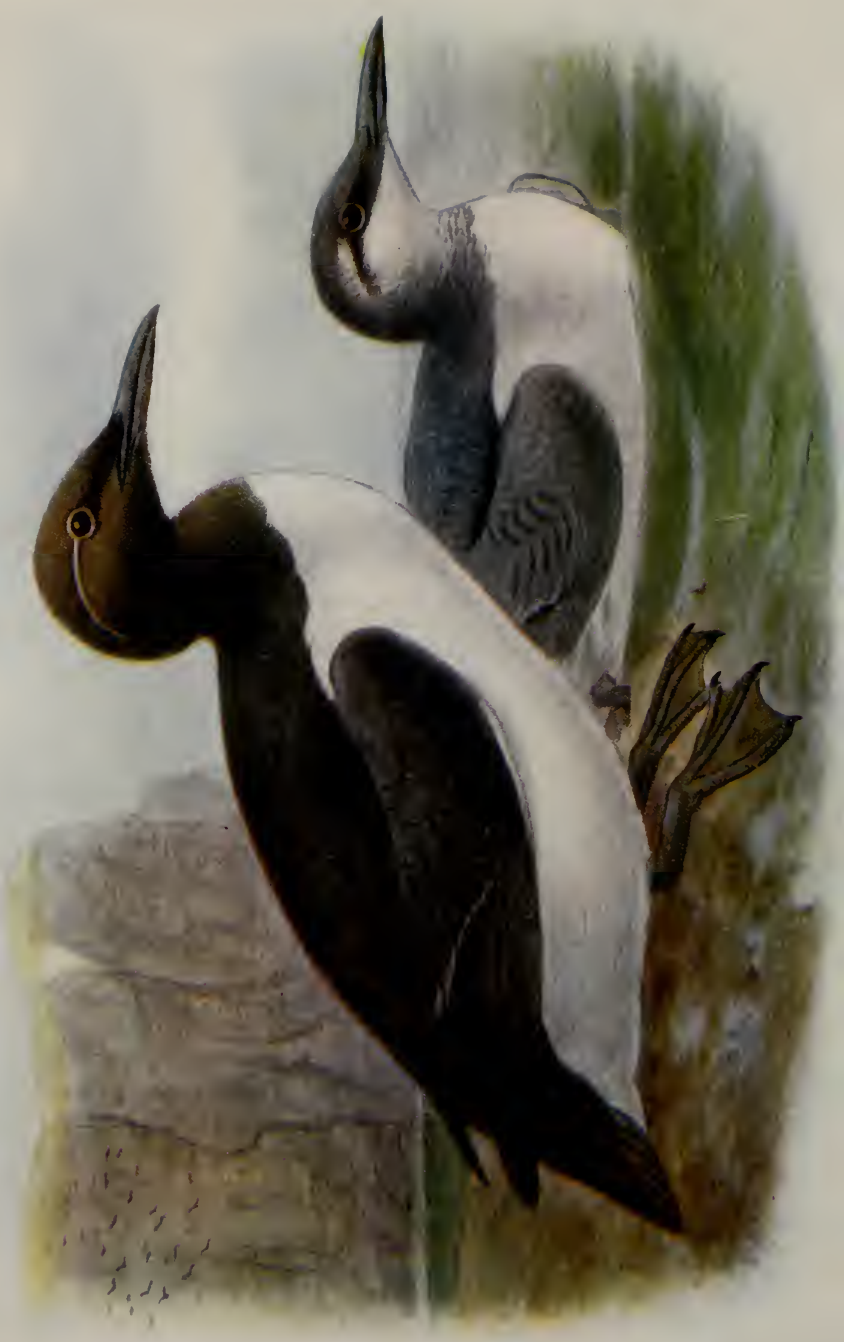





\section{Brünnich's Guillemot}

\section{BRÜNNICH'S GUILLEMOT}

\section{Uria bruennichi, E. Sabine}

This species breeds in the north of Iceland, Greenland, Spitzbergen, and on suitable cliffs throughout the Far North. Some three or four examples only have been taken off our shores.

In habits and appearance it very closely resembles the preceding species, but it may be recognised by the general colour being much darker and lacking the brownish tint of the common species. The bill is stouter and black with a whitish line along the upper mandible from the nostrils to the gape. Length 18 in.; wing 8.25 in.

\section{THE BLACK GUILLEMOT}

\section{Uria grylle (Linnæus)}

In England this species is rare even in winter, but in Scotland and Ireland it is fairly common, and breeds in suitable spots round all the coasts.

The Black Guillemot differs in many respects from the other Auks and it is never found in vast colonies, though several pairs will often breed in close proximity. Some hole or recess in a cliff or among broken rocks on a steep slope is chosen and two eggs are deposited, which are whitish spotted with grey and brown and elliptical in shape. 


\section{Birds of Britain}

Both sexes take part in the incubation, and the young are said not to leave the nest until they are fully fledged. Their food consists of fish and crustaceans, which they obtain by diving.

The sexes are alike in plumage, and in summer are of a uniform sooty brown all over, with the exception of a patch on the wing, which is white. Bill black. Legs vermilion red.

In winter the crown is black marked with white, the back barred with black and white, and the rest of the plumage white. The young resemble the adults in winter hut are rather whiter. Length $14 \mathrm{in.;}$ wing $6.5 \mathrm{in}$.

\section{THE LITTLE AUK}

\section{Mergulus alle (Linnæus)}

This species is an inhabitant of Arctic seas, breeding in Greenland, Spitzbergen, and Franz Josef Land, but it does not occur in Arctic America nor to the east of the Kara Sea. In winter it migrates southwards and a few are found round our northern shores every year, but in severe winters it often occurs in considerable numbers, and many stormdriven birds are found in a dying condition far inland.

There is a small white spot over the eye, but otherwise the plumage is sooty black on the upper parts. The under parts are white, but in summer the chin and throat are black. Length $8.5 \mathrm{in}$; wing 4.65 in. 



\section{BLACK GUILLEMOT}

Uria srylle

Summer (below). Winter (above) 


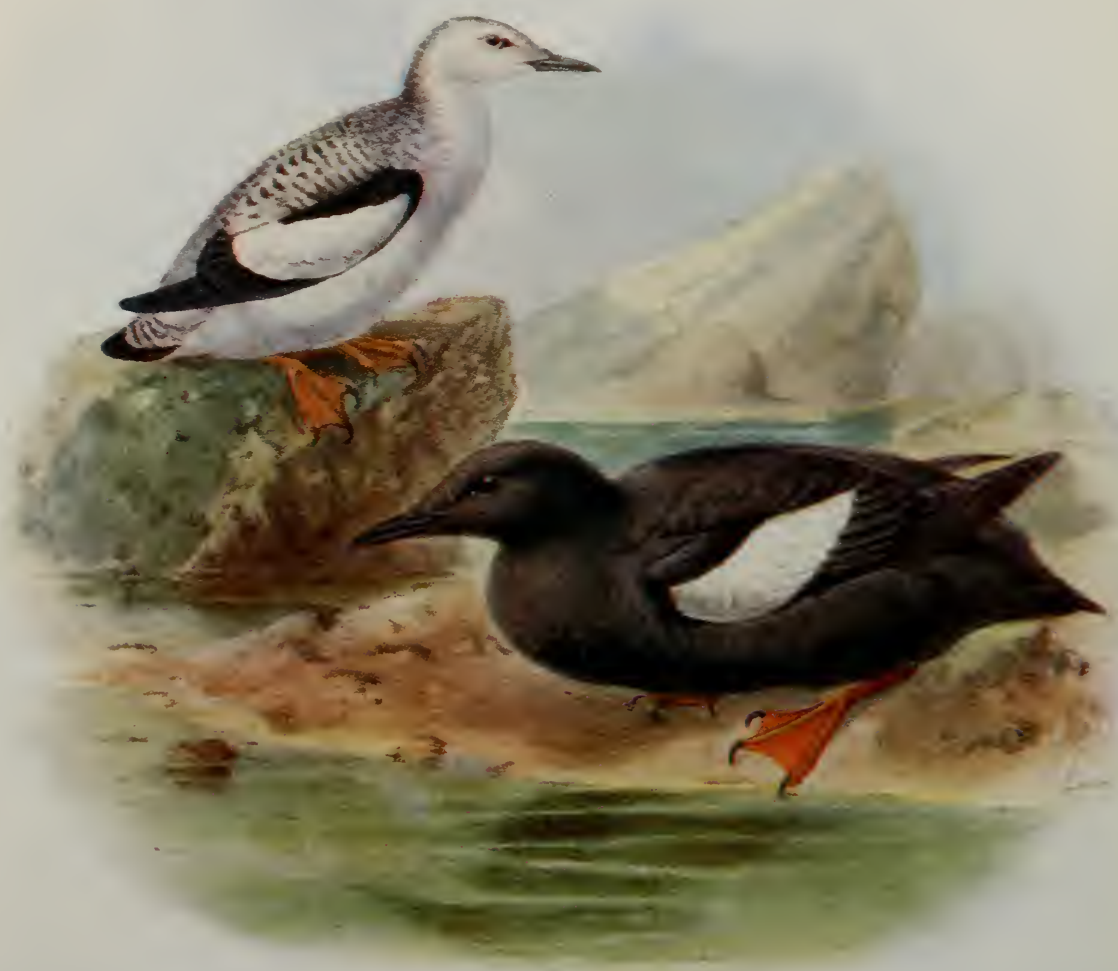





\section{Puffin}

\section{PUFFIN}

\section{Fratercula arctica (Linnæus)}

One of the most fascinating points in connection with this quaint bird is that for at least six months in every year we know nothing, or comparatively nothing, of its habits or whereabouts.

Towards the middle of April it suddenly appears at certain well-known haunts and proceeds forthwith to set up housekeeping.

A hole or cranny in a rock or, where possible, a rabbitburrow is fixed upon as its home, and the same entrance is often shared by several pairs as well as the rabbit.

A weird little creature is our friend as he sits bolt upright on his doorstep, turning round every now and again to bill and coo with his mate, their large orange-red beaks and feet showing up brightly against their black-and-white plumage. The wings are so short that this bird finds some difficulty in rising from a flat surface, and when ou the wing will often fly round in spiral curves in order to reach the summit of the cliff. In flight the legs are held spread out behind on either side of the very short tail and help to act as rudders.

The large single white egg being laid, both birds take their turn at incubation, and invariably sit with their head facing the entrance, and woe betide any one who by mistake enters the wrong hole, for their beaks are exceeding sharp 


\section{Birds of Britain}

and powerful, and they cling on with all the tenacity of a bull-dog.

They feed chiefly by night and spend the day resting on the water or at the mouth of their burrows. The food consists of small fry, and when feeding their young as many as three or four fish are caught and carried up in their bill at the same time. If approached by boat, they remain till one is just on them, and then suddenly dive. Under the water their progress is extremely rapid, and both wings and feet are brought into play, but especially the former.

The young are clad in very thick long down of a dark smoke-grey colour. As they grow they will often move about the passage, running to the entrance and meeting their parents, but never venturing outside, while if they meet another young one bound on a similar errand a stern fight ensues.

Not, however, till they are fully fledged do they leave the burrow and then immediately take to the water, on which they are quite at home, swimming and diving with ease from the very first.

The parents, whose plumage has lately been showing signs of wear, now commence to moult, and shed at the same time the ornate sheath at the base of the bill and over the eye, while the beak itself becomes dark and the rosette at the corners of the mouth shrinks. A few more days and by the end of August they have gonewhere? They are never seen, and the only evidence of their existence is the occasional occurrence of a dead or starving individual washed ashore or blown inland by a winter's gale. 


\section{Puffin}

The head, nape, and the whole of the upper parts and a broad collar round the throat are black. Scales of the head and under parts white. Legs deep orange. Bill chiefly red and orange. The young resemble the parents, except that the beak is much smaller and the legs are pale fleshcoloured. The mode of growth of their wings is quite distinct from that of the Guillemot, the primaries being grown simultaneously with the rest of the plumage. Length 13 in.; wing 6 in.

\section{THE GREAT NORTHERN DIVER}

\section{Colymbus glacialis, Linnæus}

During autumn and winter this species is by no means rare along our coasts. It does not remain to breed on any part of Great Britain, but breeds to the north-west in Iceland, Greenland, and North America.

It feeds entirely on fish, and the adults generally keep well out at sea, unless the weather be stormy, so that the individuals that frequent our shores are mostly immature.

In autumn the young bird has the feathers of the back greyish brown with paler margins; under parts whitish. Bill brownish horn colour.

The adult in its breeding dress has the back black, each feather having two square white spots; the head and neck are black with a purplish gloss, except for two crescentic bands on the fore neck, which are longitudinally striped with white and black. After the autumn moult the whole of the 


\section{Birds of Britain}

upper parts are pale slaty blue, the head and nape dusky grey, chin and throat white. This plumage is, however, worn for an exceedingly short time and is rarely complete, signs of the new breeding dress appearing before all old feathers have been cast.

The winter feathers of the head and neck are downy. Length 30.32 in.; wing 13.14 in.

\section{THE WHITE-BILLED NORTHERN DIVER}

\section{Colymbus adamsi, G. R. Grey}

This species breeds in the Far North, wandering south in winter; two or three examples have been taken on our shores, and it is probable that owing to its resemblance to the preceding species it has been often overlooked.

The chief characteristic is the bill, which is yellowish white at all seasons, and the lower mandible is also markedly upturned. The white streaks on the transverse throat bands are much fewer in number than in the preceding species. Length about $33 \mathrm{in.}$; wing $15 \cdot 1 \mathrm{in.}$

\section{THE BLACK-THROATED DIVER}

\section{Colymbus arcticus, Linnæus}

The Black-throated Diver is very rare in England, and the few examples that are obtained are usually immature. 


\section{The Black-throated Diver}

In Ireland it has only been taken at long intervals, but in Scotland it breeds locally throughout the north and west.

The site chosen for the nest is usually an islet in some large loch, and the eggs, two in number, are olive brown, sparsely spotted with black and brown. The young when first hatched are of a uniform smoky grey-brown.

In its habits it closely resembles the next species. In summer the back is black, spotted with white, but the spots are not so uniformly distributed as in the former species. Crown and hind neck ash grey, chin and throat black, margined with short black and white stripes and a small band of similar stripes towards the upper end of the patch. Under parts white. The sexes are alike, but the females are slightly smaller. After the autumn moult the chin and throat are white and the upper parts ash brown.

The young bird resembles the young of the Great Northern Diver, but is much smaller and the neck is greyer. Length 27 in.; wing 11.75 in.

\section{THE RED-THROATED DIVER}

\section{Colymbus septentrionalis, Linnæus}

This species is the commonest of the Divers and may be found along all our coasts during the winter months. In the breeding season, except for a few pairs that may still be found on some of the Irish loughs, it is restricted to Scotland so far as our islands are concerned. 


\section{Birds of Britain}

The eggs are laid close to the margin of some small tarn or on an islet in a large loch, but the former situation is the one preferred; they are elongate and olive brown, spotted with umber. The young leave the nest as soon as they are hatched, but they are not very strong divers at first and receive all their food from their parents; in fact this species often nests on ponds destitute of fish, and journeys several miles to the sea or large loch daily for its food. If the nest be approached the sitting bird glides off and dives without a ripple, reappearing again some way off. The note is a loud and mournful "kark, kark, kakera."

In winter the adult is brown on the back, spotted with small white spots. The under parts are pure white, and head and neck, on which the feathers are very downy, are greyish brown on the crown and nape and white on the chin and throat. In summer the white spots on the back disappear; the crown and nape are slate grey streaked with black; the sides of the head and neck are pale grey and there is a longitudinal patch of chestnut down the fore-neck. The sexes are alike in plumage. The young bird in winter may be distinguished by the spots on the back being longer and tending to form arrow-shaped markings, and the feathers of the vent have narrow brown margins. Length $24 \mathrm{in.}$; wing $11 \cdot 2$ in. 

RED-THROATED DIVER

Colymbus septentrionalis

Adult in summer (right). Young (left) 


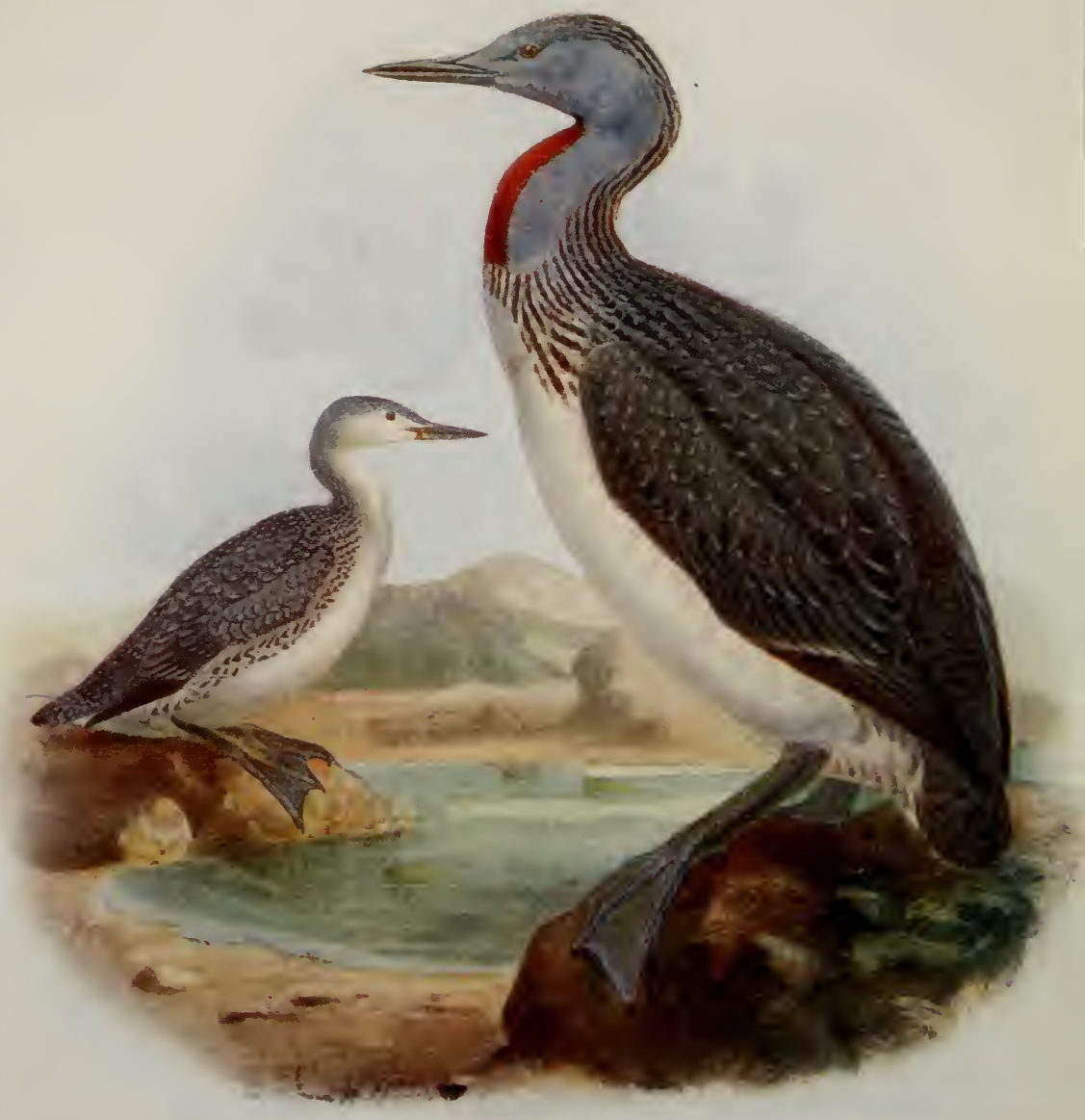





\section{The Great Crested Grebe}

\section{THE GREAT CRESTED GREBE}

\section{Podicipes cristatus (Linnæus)}

In the course of these pages we have often had to lament the extermination or decrease of many species, so that it is a real pleasure to have to record that a fine species like the present has increased abundantly of late years.

This has been largely brought about by very strict protection, and although still local, there are many places where it is now common, and in Scotland it breeds on several lochs as far north as Aberdeenshire. In Ireland also it nests in several localities. It is practically a resident and may be found with us at all times of the year, but after the breeding season the majority leave their summer haunts and may be found in the estuaries and bays along the coast. The nest is a large floating mass of decaying vegetation generally well hidden among thick reeds, though occasionally it is placed in the open. The eggs, usually four in number, are yellowish white when first laid, but soon become stained to a dirty brown from contact with the decaying vegetable matter with which they are always covered when the sitting bird leaves the nest. The young when first hatched are dark brown, longitudinally striped with white; they are carefully tended by both their parents, who often carry them on their backs. The food consists of fish, crustaceans, and any other living food which may be found.

This bird may usually be seen swimming about in the 387 


\section{Birds of Britain}

centre of the open water, its long neck and low flat back enabling it to be easily recognised.

It flies well and strongly, appearing when on the wing rather like a Duck.

In winter it is dark brown above and white below, but in spring it assumes a chestnut tippet which surrounds the face; the crown of the head is dark brown, the cheeks and a stripe over the eye white.

The female is rather duller but otherwise resembles the male. The young in their first plumage are much like the adults in winter. Length $21 \mathrm{in}$; wing $7.5 \mathrm{in}$.

\section{THE RED-NECKED GREBE}

\section{Podicipes griseigena (Boddaert)}

On the east coast of England this species is not uncommon during the winter months, and in some seasons becomes quite abundant. Elsewhere in our area it is decidedly rare, and not more than five or six examples are recorded from Ireland. It is plentiful in the south of Scandinavia, the Baltic, and North Russia, whence it migrates southwards throughout Europe in the winter. In habits and food it does not appreciably differ from the preceding species.

The crown and nape are blackish, upper parts dark brown with a white patch on the secondaries.

Cheeks, chin, and throat grey; neck rich chestnut red; rest of under parts white. Length 18 in.; wing 7 in. 

GREAT CRESTED GREBE

Podicipes cristatus

Adult, summer (right). Young (left) 


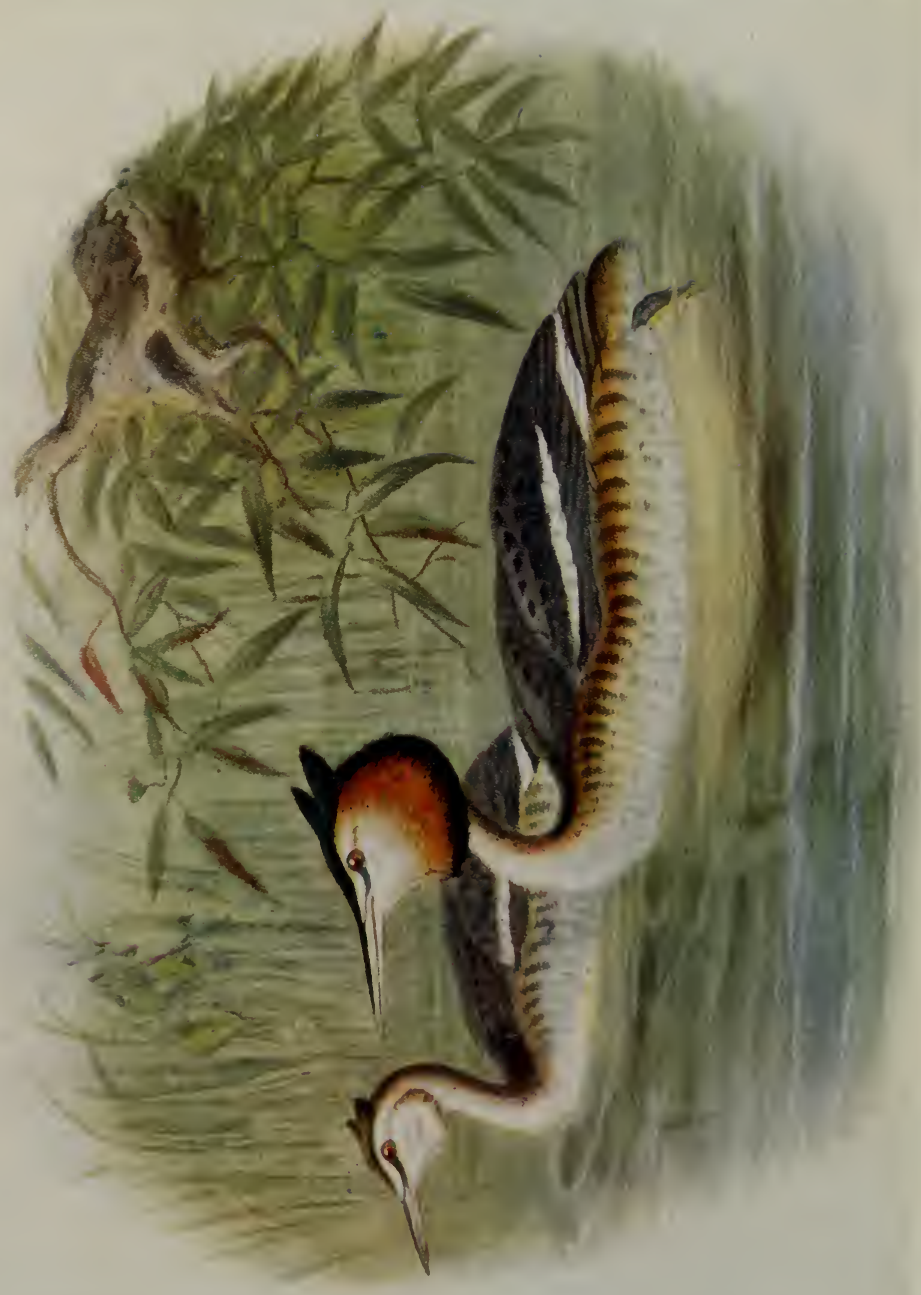




\section{The Slavonian or Horned Grebe}

\section{THE SLAVONIAN OR HORNED GREBE}

\section{Podicipes auritus (Linnæus)}

This is a northern species, breeding in Iceland, Scandinavia, and Russia, which visits our shores, especially in the east, annually, and in the north of Scotland it is quite common. Ireland is also regularly visited on migration every year.

In summer the upper parts are dark brown; the crown, forehead, chin, and tippet black, and a tuft of elongated feathers on each side of the head chestnut. Secondaries white, except the three outer ones, which are dusky like the primaries; neck, breast, and flanks warm chestnut; belly white. In winter the crest is absent; the under parts are white. The young resemble their parents in winter dress. Length 13.5 in.; wing $5.5 \mathrm{in}$.

\section{THE BLACK-NECKED OR EARED GREBE}

\section{Podicipes nigricollis, C. L. Brehm}

Unlike the preceding species, this is a southern Grebe, stragglers of which are occasionally met with most frequently in spring, and there is evidence that it may have nested with us on more than one occasion. To Scotland and Ireland it is a very rare wanderer.

The adult in spring has the head and neck black with 389 


\section{Birds of Britain}

a triangular patch of yellowish chestnut feathers on the ear coverts; upper parts dark brown; under parts white; flanks chestnut. All the secondaries white, and a good deal of white on the four innermost primaries. Bill black, up-curved in front of the angle. In winter the ear tufts and black on the throat are lost, and at this season it closely resembles the preceding species, but the white on the primaries will always serve to distinguish it. Length 12 in.; wing 5 in.

\section{THE LITTLE GREBE OR DABCHICK}

\section{Podicipes fluviatilis (Tunstall)}

The Little Grebe is abundant on rivers, streams, and ponds throughout the country, but becomes scarcer in the north of Scotland. It must be tolerably familiar to every one as a short squat little bird that dives at the smallest alarm, only coming to the surface again some distance away, most often among the reeds and aquatic vegetation near which this bird is always found. The nest is a fair-sized mass of dead weeds floating on the surface of the water and generally moored to some reed stems.

The eggs, usually five in number, are of a uniform yellowish white, but soon become discoloured by the weeds with which they are always covered when the bird is not sitting. The nestling is striped, and fed by its parents on insects and small fish. These birds are seldom seen on the wing and hardly ever on land, but nevertheless they are well able to stand up and even walk when on shore. 


\section{The Little Grebe or Dabchick}

In suminer the plumage, except for the cheeks, throat, and sides of the neck, which are chestnut, is dark brown all over, rather lighter on the under parts.

In winter the chin, neck, and under parts are nearly white. The plumage of the young resembles the winter dress of their parents but is a little duller, and there is more white about the cheeks. Length $9.5 \mathrm{in}$; wing 4 in.

\section{THE STORM PETREL}

\section{Procellaria pelagica, Linnæus}

This is the commonest of the Petrels which come to our shores to breed, for as a rule these birds live far out at sea and only visit the shore to breed or when driven inland by stress of weather or on migration. About their migrations little or nothing is known, but in October and November this species regularly strikes many of our lighthouses and lightships, being attracted by the light. It is found along the whole of the countries fringing the Atlantic, and nests from the Faroes southwards, and also along the shores of the western end of the Mediterranean.

The single white egg is deposited during the latter half of June down holes in heaps of stones, in rabbit-burrows, or in any other spot affording suitable concealment. Incubation, which is probably undertaken by both sexes, lasts about thirty-five days, the nestling when hatched being covered with long black down. Their food consists of crustaceans, small fish, and fatty matter of any kind. They are nocturnal, 


\section{Birds of Britain}

during the breeding season at all events, only leaving their retreat after dark and returning before dawn, so that it is very difficult to detect their presence. The sitting bird, however, utters a curious note while sitting, and a strong musky odour pervades the burrow, so that by this means the nest may frequently be found. If handled, the bird emits a greenish oil.

In England it only nests sparingly on the coast of Wales and in the Scilly Islands, but in Scotland and Ireland its breeding places are numerous.

The adult is sooty black all over, but the bases of the tail coverts are white and the edges of the wing coverts are slightly edged with white. Length $6.5 \mathrm{in}$; wing $4.7 \mathrm{in}$.

\section{LEACH'S FORK-TAILED PETREL}

\section{Oceanodroma leucorrhoa (Vieillot)}

This species is a regular but not very numerous visitor to our shores every autumn, its numbers depending largely on the weather, and after heavy gales it is often found inland. It nests in small numbers on St. Kilda and some of the Outer Hebrides, and has also been found nesting off the coast of Kerry; and in time many other breeding stations will probably be found on the islands of our western shores. The single egg is white freckled with rusty spots. In its food and labits it resembles, so far as they are known, those of the Storm Petrel.

The adult is dark leaden black, rather more sooty below; 

STORM PETREL

Procellaria pelagica

(right)

LEACH'S PE'TREL

Oceanodromas leucorrhoa

(left) 


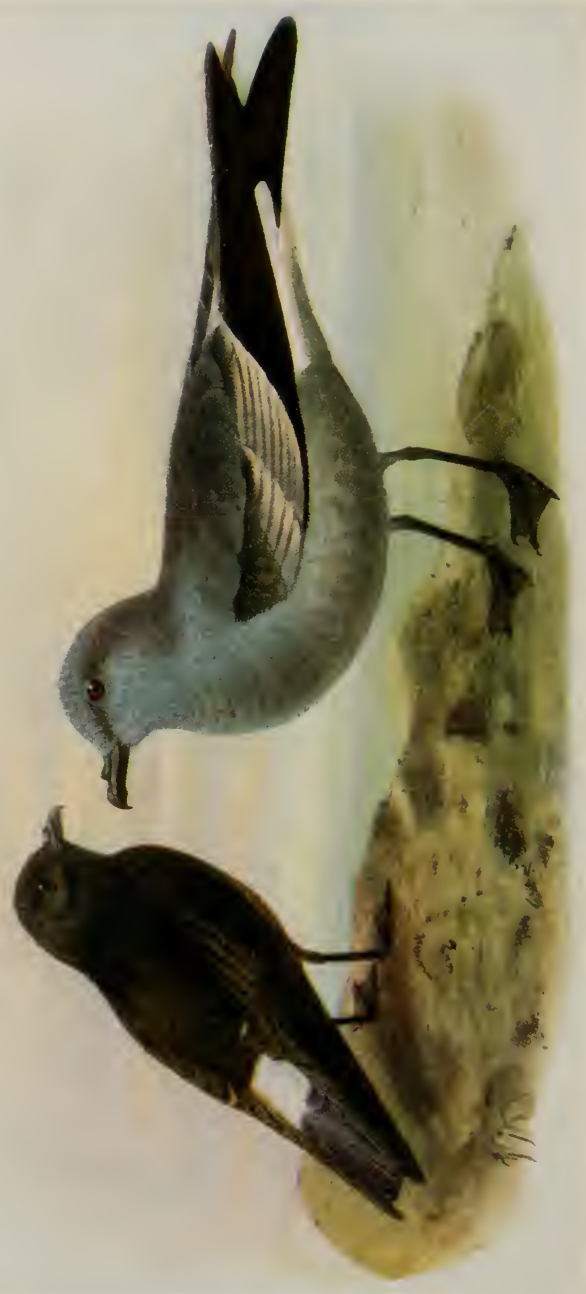





\section{Leach's Fork-tailed Petrel}

ujper tail coverts white: tail sooty black and deeply forked. Length 8 in.; wing 6 in.

\section{MADEIRAN FORK-TAILED PETREL \\ Oceanodroma castro (Harcourt)}

An example of this bird was picked up dead in Kent in December 1895 .

The home of this species is the islands lying off the west of Africa, viz. Cape Verde, Madeira, Desertas, Salvages, and Canaries, from whence individuals occasionally wander to Europe.

This species very closely resembles Leach's Petrel, but the tail is hardly forked; the upper tail coverts are white tipped with black; and the bases of the tail feathers are white. Length nearly $S$ in.; wing 5.9 in.

\section{WILSON'S PETREL}

\section{Oceanites oceanicus (Kuhl)}

This bird is almost cosmopolitan in distribution, but perhaps the South Atlantic is its main home, and it is commoner up the North American coast than on this side. Several examples have been shot in this country. The legs and wings are longer than in the preceding species and the webs of the feet are yellow at their bases. The general colour above and below is sooty brown with white on upper 


\section{Birds of Britain}

tail coverts and thigh patches, and also at the base of the outer tail feathers. Length $7 \mathrm{in}$; wing $6 \mathrm{in.}$

\section{THE FRIGATE PETREL}

Pelagodroma marina (Latham)

Of late years two examples of this Petrel have been washed up on our shores. The Salvages are the nearest breeding haunts of this species, but it is also found in the south seas.

The crown, nape, and patch behind the eye are slate grey ; upper parts grey; wing coverts brown; quills blackish. Tail black; under parts white tinged with grey on the flanks. Length $7 \cdot 75$ in.; wing 6.25 in.

\section{THE GREAT SHEARWATER \\ Puffinus gravis, $0^{\prime}$ Reilly}

This species is a fairly regular summer visitor to the waters round our coasts, but it does not often approach the land.

Nothing is known of its breeding haunts, which are probably in the Antarctic seas.

The upper parts are ash brown, mottled with white on the upper tail coverts. Under parts white, sometimes brownish on the belly. Legs pinkish. Length $19 \mathrm{in}$; wing 127 in. 


\section{The Sooty Shearwater}

\section{THE SOOTY SHEARWATER \\ Puffinus griseus (J. F. Gmelin)}

This species visits us yearly but is much scarcer than the Great Shearwater.

Its only known nesting haunts are in Chatham Islands and others near New Zealand, but the birds which visit us probably nest in the South Atlantic.

The whole of the plumage is brown, rather greyer below and more mottled. Legs blackish outside, lilac grey within. Length 18 in.; wing 12 in.

\section{THE MEDITERRANEAN GREAT SHEARWATER \\ Puffinus kuhli (Boie)}

A single specimen of this Atlantic and Mediterranean Shearwater was picked up on the Sussex coast in 1906 . It is similar to the Dusky Shearwater but greyer, wings and tail blackish brown, under parts pure white. Length $17 \cdot 25$ in. ; wing $12 \cdot 75$ in.

\section{THE MANX SHEARWATER}

\section{Puffinus anglorum (Temminck)}

The Manx Shearwater is the commonest of the Shearwaters that are found round our coasts. It is resident 


\section{Birds of Britain}

with us throughout the year, feeding chiefly on fish, offal, etc., that it finds on or near the surface.

During the nesting season it retires to secluded parts of the coast, where it lays its single white egg in rabbit-burrows or other crevices. It is not known to breed on the east coast, but down the west from Wales northwards as well as in Ireland it breeds commonly, though from its nocturnal habits the nest is not always easy to find.

It may be distinguished when flying by its rounded wings and its habit of progressing with wings held motionless close over the surface of the water.

The crown, nape, and upper parts are sooty black, under parts white, except for a patch of sooty brown behind the thighs; legs and feet flesh-coloured; outer toes black. Length 15 in.; wing 9.5 in.

\section{THE LITTLE DUSKY SHEARWATER}

\section{Puffinus assimilis, Gould}

This is another species inhabiting the Salvages and islands off the west coast of Africa.

Some three or four examples have been obtained, which were originally wrongly identified as $P$. obscurus, an American species.

The upper parts are slaty black and under parts white. Bill and legs blackish; webs yellow. Length 10.5 in.; wing $7 \cdot 4 \mathrm{in.}$ 


\section{The Capped Petrel}

\section{THE CAPPED PETREL}

AEstrelata hæsitata (Kuhl)

Extremely little is known of this species, which used to nest in the West Indies. It has occurred here on one occasion only.

The crown, nape, and mantle are dark brown; hind-neck and upper tail coverts white; cheeks grey; forehead and under parts white; central tail feathers brownish black; the rest, white edged with brown. Length 16 in.; wing $11 \cdot 3$ in.

\section{THE COLLARED PETREL}

\section{Æstrelata brevipes (Peale)}

A single example of this Petrel was obtained off the coast of Wales in December 1889. The southern and western Pacific appear to be its true home.

The crown is slaty grey; rest of upper parts darker, becoming browner on the wing coverts. Forehead and throat white; rest of under parts white, sometimes tinged with grey. Length 11.5 in.; wing $8.7 \mathrm{in.}$ 


\section{Birds of Britain}

\section{BULWER'S PETREL}

\section{Bulweria bulweri (Jardine and Selby)}

This small Petrel is a common resident in the Canaries and neighbouring islands, but only one individual has straggled to our shores.

The plumage is of a uniform sooty brown; tail wedgeshaped. Bill black. Legs reddish brown. Length 11 in.; wing 8 in.

\section{THE FULMAR}

\section{Fulmarus glacialis (Linnæus)}

Although not very rare, this bird is seldom seen, as it spends most of its time at sea in attendance on the fishingboats or on the banks where the fish abound. In Scotland it nests on St. Kilda and a few of the other islands of that group; while in the Shetlands, where it was first known to nest in 1878 , it has now spread to several of the neighbouring stacks.

The nest is placed on a ledge on the face of a precipitous cliff, and the single egg is pure white with a few reddishbrown spots. The young are at first nourished on a yellowish oil vomited by the parent birds, and large numbers are annually taken in St. Kilda for the sake of this oil. It may easily be distinguished from a Gull on the wing by its peculiar flight and rounded wings. 


\section{The Fulmar}

The back and tail are grey, the rest of the bird white. Bill yellowish; legs ash colour. The young resemble their parents. The more northerly form of this bird has greyish under parts and may be met with in Scotland in winter. Length 19 in.; wing 13.25 in.

\section{THE BLACK-BROWED ALBATROSS}

\section{Diomedea melanophrys, Boie}

The true home of this species is in the southern seas near the Chatham Islands and New Zealand, but it has been known for some time past to occasionally visit the North Atlantic.

A specimen was obtained near Cambridge on the 9th of July 1897.

The adult has a short black band passing through and above the eyes; back and wings brownish black; tail feathers grey; rest of the plumage white. Length $27 \mathrm{in}$; wing 17 in. 



\section{NDEX}

Accentor, Alpine. 70

Hedge, 67

Albatross, Black-browed, 399

Auk, Great, 377

Little, 380

A rocet, 312

Bee-Eater, 181

Bittern, American, $22 S$

Common, 227

Little, 227

Blackbird, 15

Blackeap, 45

Bluethroat, 34

Brambling, 128

Bullfinch, 135

Bunting, Black-headed, 139

Cirl, 143

Corn, 140

Lapland, 149

Little, 146

Meadow, 145

Ortolan, 144

Reed, 147

Rustic, 145

Siberian Meadow, 145

Snow, 150

Yellow, 141

Yellow-breasted, 147

Bustard, Great, 292

Little, 292

Macqueen's, 293

Buzzard, Common, 201

Honey, 210

Rough-legged, 203

Capercaillie, 274

Chaffinch, $126^{\circ}$

Chiffchaff, 53

Siberian, 51
Chough, 154

Coot, 290

Cormorant, 219

Courser, Cream-coloured, 296

Crake, Baillon's, 28T

Little, 286

Spotted, 285

Crane, 291

Creeper, Tree-, 85

Wall-, 85

Crossbill, 137

Two-barred, 139

Crow, Carrion, 163

Hooded, 164

Cuckoo, 186

American Yellow-billed, 159

Great Spotted, 189

Curlew, 347

Eskimo, 349

Dabchick, Little Grebe or, 390

Dipper, 70

Diver, Black-throated, 384

Great Northern, $3 \$ 3$

Red-throated, 395

White-billed Northern, $3 \$ 4$

Dotterel, 290

Dore, Rock, 271

Stock, 270

Turtle, $2 i_{2}$

Duck, Buffel-headed, $25 \mathrm{~S}$

Common Sheld, 239

Eider, 260

Ferruginous, 254

Golden-eye, 257

Harlequin, 259

Long-tailed, 258

Mallard, or Wild, 241

Ruddy Sheld, 240

Scaup, 256 


\section{Birds of Britain}

Duck, Tufted, 255

Dunlin, 324

Eagle, Golden, 204

Spotted, 203

White-tailed, 205

Egret, Little, 225

Eider, King, 261

Steller's, 261

Falcon, Greenland, 211

Gyr, 211

Iceland, 211

Red-footed, 215

Fieldfare, 10

Finch, Citril, 120

Firecrest, 51

Flamingo, 230

Flycatcher, Pied, 107

Red-breasted, 108

Spotted, 105

Fulmar, 398

Gadwall, 244

Gannet, 222

Garganey, 250

Godwit, Bar-tailed, 345 Black-tailed, 346

Goldfinch, 117

Goosander, 264

Goose, Bean, 233

Bernacle, 235

Brent, 235

Grey Lag, 231

Pink-footed, 233

Red-breasted, 234

Snow, 234

White-fronted, 232

Goshawk, 206

Grebe, Black-necked or Eared, 389

Great Crested, 387

Little, 390

Red-necked, 388

Slavonian or Horned, 389

Greenfinch, 114

Greenshank, 343

Grosbeak, Pine, 137 Scarlet, 136

Grouse, Black, 275

Pallas' Sand, 273

Red, 276

Guillemot, Black, 379

Brünnich's, 379
Guillemot, Common, 377

Gull, Black-headed, 360

Bonaparte's, 359

Common, 363

Glaucous, 368

Greater Black-backed, 367

Great Black-headed, 362

Herring, 364

Iceland, 369

Ivory, 371

Kittiwake, 369

Lesser Black-backed, 366

Little, 360

Mediterranean Black-headed, 362

Sabine's, 358

Wedge-tailed, 359

Harrier, Hen, 200

Marsh, 199

Montagu's, 200

Hawfinch, 115

Hawk, Sparrow, 207

Hen, Moor, 288

Heron, 223

Buff-backed, 225

Great White, 225

Night, 226

Purple, 224

Squacco, 226

Hobby, 214

Hoopoe, 185

House-Martin, 112

Sparrow, 121

Ibis, Glossy, 229

Jackdaw, 160

Jay, 156

Kestrel, 216

Lesser, 218

Kingtisher, 182

Kite, 208

Black, 210

Knot, 330

Lapwing, 306

Lark, Black, 171

Crested, 170

Shore, 172

Short-toed, 170

White-winged, 171 


\section{Index}

Lark, Wood, 169

Linnet, 129

Magpie, 159

Mallard, or Wild Duck, 241

Martin, House-, 112

Sand-, 113

Merganser, Hooded, 267

Red-breasted, 265

Merlin, 214

Moor-hen, 288

Nightingale, 38

Nightjar, 175

Noddy, 358

Nutcracker, 156

Nuthatch, 81

Oriole, Golden, 99

Osprey, 219

Ouzel, Ring, 19

Owl, Barn, 190

Eagle, 197

Hawk, 196

Little, 195

Long-eared, 191

Scops, 197

Short-eared, 192

Snowy, 196

Tawny, 193

Tengmalm's, 194

Oyster-Catcher, 310

Partridge, 280

Red-legged, 281

Pastor, Rose-coloured, 154

Peregrine, 212

Petrel, Bulwer's, 398

Capped, 397

Collared, 397

Frigate, 393

Leach's Fork-tailed, 392

Madeiran Fork-tailed, 393

Storin, 391

Wilson's, 393

Phalarope, Grey, 314

Red-necked, 315

Pheasant, 279

Pigeon, Wood, 268

Pintail, 247

Pipit, Meadow, 94

Reil-throated, 95
Pipit, Richard's, 97

Rock, 98

Tawny, 96

Tree, 92

Water, 97

Plover, Caspian, 298

Golden, 302

Grey, 305

Kentish, 301

Killdeer, 302

Lesser Golden, 304

Little Ringed, 301

Ringed, 298

Sociable, 306

Pochard, Common, 253

Recl-crested, 252

Pratincole, 295

Black-winged, 296

Ptarmigan, 278

Puffin, 381

Quail, 282

Rail, Land, 283

Water, 287

Raven, 161

Razorbill, 375

Redpoll, Lesser, 132

Mealy, 131

Redshank, Common, 340

Spotted, 342

Redstart, 31

Black, 33

Redwing, 8

Reedling, Bearded, 71

Robin, 35

Roller, 184

Rook, 165

Rutf, 333

Sand-Martin, 113

Sanderling, 331

Sandpiper, American Pectoral, 322 Baird's, 326

Bartram's, 335

Bonaparte's, 323

Broad-billed, 321

Buff-breasted, 335

Common, 336

Curlew, 328

Green, 338

Purple, 329 


\section{Birds of Britain}

Sandpiper, Siberian Pectoral, 323

Solitary, 339

Spotted, 337

Wood, 337

Scoter, Cornmon, 262

Surf, 264

Velvet, 263

Serin, 121

Shag, 221

Shearwater, Great, 394

Little Dusky, 396

Manx, 395

Mediterranean Great, 395

Sooty, 395

Shoveller, 245

Shrike, Great Grey, 100

Lesser Grey, 101

Masked, 104

Red-backed, 102

Siskin, 119

Skua, Arctic or Richardson's, 373 Great, 371

Long-tailed or Buffous, 374

Pomatorhine, 372

Skylark, 167

Smew, 266

Snipe, Common, 319

Great or Solitary, 318

Jack, 321

Red-breasted, 345

Snow-Finch, 129

Sparrow, "Hedge," 67

House-, 121

Tree-, 124

Spoonbill, 230

Starling, 151

Stilt, Black-winged, 313

Stint, American, 327

Little, 326

Temminck's, 327

Stone-Curlew, 293

Stonechat, 29 Siberian, 31

Stork, Black, 229

White, 228

Swallow, 109

Red-rumped, 111

Swan, Bewick's, 237

Mute, 237

Whooper, 236

Swift, 173

Alpine, 175
Teal, 248

American Green-winged, 249

Blue-winged, 249

Tern, Arctic, 356

Black, 349

Caspian, 352

Common, 354

Gull-billed, 351

Little, 357

Roseate, 353

Sandwich, 352

Sooty, 358

Whiskered, 351

White-winged Black, 350

Thrush, Black-throated, 14

Dusky, 18

Missel, 1

Rock, 22

Song, 4

White's, 14

Tit, Bearded, 71

Blue, 79

Coal, 77

Crested, 81

Great, 75

Long-tailed, 74

Marsh, 78

Tree-Creeper, 85

Sparrow, 124

Turnstone, 309

Twite, 133

Vulture, Egyptian, 198

Griffon, 198

Wagtail, Blue-headed, 90

Grey, 89

Pied, 86

White, 88

Yellow, 91

Wall-Creeper, 85

Warbler, Aquatic, 65

Barrerl, 47

Cetti's, 59

Dartford, 48

Garden, 46

Grasshopper, 65

Great Reed, 63

Greenish Willow, 52

Icterine, 59

Marsh, 62

Melodious, 60 


\section{Index}

Warbler, Orphean, 44

Pallas' Willow, 52

Radde's Bush, 58

Reed, 60

Rufous, 58

Sardinian, 44

Savi's, 66

Sedge, 63

Sub-Alpine, 48

Yellow-browed, 51

Waxwing, 104

Wheatear, 22

Black-eared, 26

Black-throated, 26

Desert, 27

Isabelline, 25

Whimbrel, 348

Whinchat, 27

Whitethroat, 40

Lesser, 42

Wigeon, 251

American, 252

Woodchat, 103

Woodcock, 317

Woodpecker, Greater Spotted, 180

Green, 179

Lesser Spotted, 181

Wren, 83

Golden-crested, 50

Willow, 55

Wood, 56

Wryneck, 177

Yellow Hammer or Yellow Bunting, 141

Yellowshank, 340

Greater, 340

\section{THE END}

Printed by R. \& R. CLARK, Limited, Edinburgh. 

